\title{
PREDICTIONS AND ACCEPTANCE CRITERIA FOR K REACTOR STARTUP AND POWER ASSENSION (U)
}

by

R. A. Bond, Jr.

Westinghouse Savannah River Company

Savannah River Site

Aiken, South Carolina 29808

$$
\begin{aligned}
& \text { Prenom Uol } \\
& \text { IUL. a } 1992
\end{aligned}
$$

The information contained in this document was prepared in connection with work done under Contract No. DE-AC09-89SR 18035 with the U.S. Department of Energy. By acceptance of this report, the publisher and/or recipient acknowledges the U.S. Governmeni's right to retain a nonexclusive, royalty-free license in and to any copyrighe covering this report, along with the right to reproduce and to authorize others to reproduce all or part of the copyrighted report. 


\section{DISCLAIMER}

This report was prepared as an account of work sponsored by an agency of the United States Government. Neither the United States Government nor any agency thereof, nor any of their employees, makes any warranty, express or implied, or assumes any legal liability or responsibility for the accuracy, completeness, or usefulness of any information, apparatus, product, or process disclosed, or represents that its use would not infringe privately owned rights. Reference herein to any specific commercial product, process, or service by trade name, trademark, manufacturer, or otherwise does not necessarily constitute or imply its endorsement, recommendation, or favoring by the United States Government or any agency thereof. The views and opinions of authors expressed herein do not necessarily state or reflect those of the United States Government or any agency thereof.

This report has been reproduced directly from the best available copy.

Available to DOE and DOE contractors from the Office of Scientific and Technical Information, P.O. Box 62, Oak Ridge, TN 37831; prices available from (615) 576.8401, FTS 626-8401.

Available to the public from the National Techncial Information Service, U.S. Department of Commerce, 5285 Port Royal Rd., Springfield, VA 22161. 


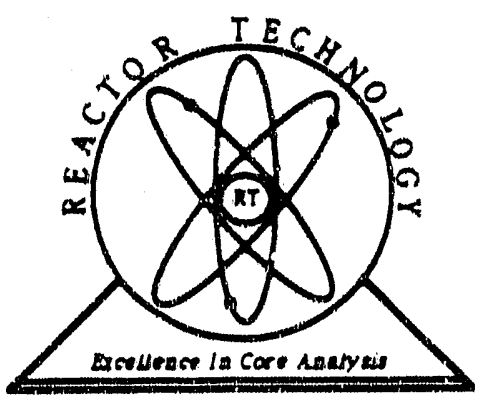

WSRC-TR-91-42-043

DOES NOT CONTAN

UNCLASSIFED CONTROLLED

NUCLEAR NFORMATION

\section{PREDICTIONS AND ACCEPTANCE CRITERIA FOR K REACTOR STARTUP AND POWER ASCENSION (U)}

BY:

R. A. BOND, JR.

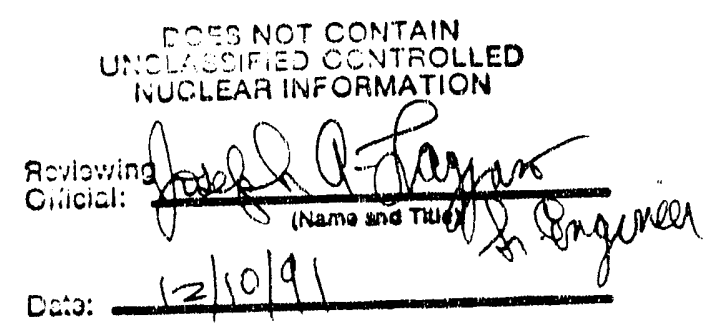

JUNE 1991

REACTOR TECHNOLOGY SECTION REACTOR ENGINEERING DEPARTMENT

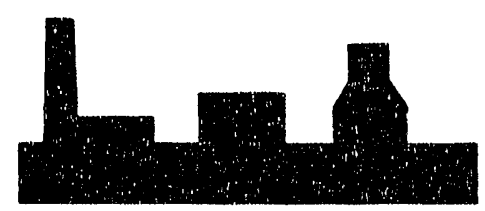


DOES NOT CONTAIN

UNCLASSIFIED CONTROULED

NUCLEAR INFORMATION

Reviewing

Official:

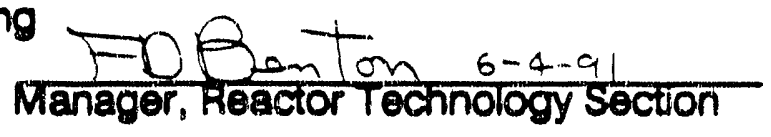

KEYWORDS:

STARTUP TESTING

K-14 MARK 22 CHARGE

POWER ASCENSION

ZERO POWER

ACCEPTANCE CRITERIA

RETENTION:

PERMANENT

CLASSIFICATION:

Unclassified

Authorized Derivative Classifier

\section{PREDICTIONS AND ACCEPTANCE CRITERIA FOR K REACTOR STARTUP AND POWER ASCENSION (U)}

BY:

R. A. BOND, JR.

ISSUED: June 4, 1991

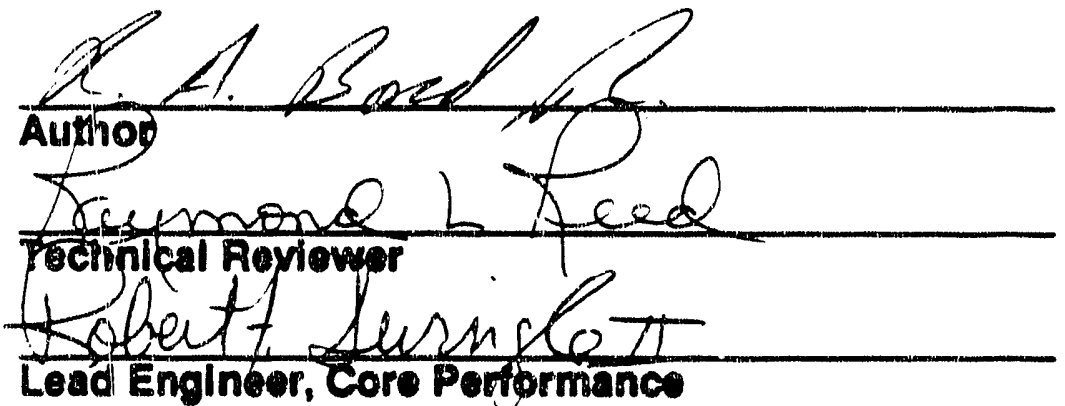

Mare Rosser Manager, Core Phyalca Manager, Reactor Tochnology
DATE: $6 / 4 / 91$

DATE: $6-4-91$ DATE: $6 / 4 / 91$ DATE: $6 / 4 / 9 /$ DATE: $6-4-91$ 
WSRC-TR-91-42-043

Page 1 of 138

June 4, 1991

PREDICTIONS AND ACCEPTANCE CRITERIA FOR K FIEACTOR STARTUP AND POWER ASCENSION (U)

\section{INTRODUCTION}

The master procedure to startup K Reactor is RSP 90-007. Within this procedure are 16 separate tests to verify that the reactor will be operated within the parameters described in the Safety Analysis Report (SAR), Safety Evaluation Report (SER), and Technical Specifications. Several of these tests will provide data to benchmark reactor physics computer codes that are used in core design and safety analysis. RSP 90-007 applies acceptance criteria or expectation ranges to results of measurernents performed in each test. Calculations for the predictions have been performed by various members of Reactor Technology in the Reactor Engineering Department and Reactor Physics of Savannah River Laboratory. This technical report combines all predictions and acceptance criteria into one document.

\section{SUMMARY}

The purpose of this report is to consolidate all the work performed on the predictions and acceptance criteria for the K Reactor Startup and Power Ascension Test Program. All results reported in this document are referenced to technical documents. This report consolidates the results of several technical reports previously issued. The technical background of the results can be found in the references given in this document.

\section{DISCUSSION}

This discussion briefty describes the predictions and acceptance criteria of each test. The individual tests are discussed and referenced separately. 
WSRC.TR- $91-42-043$

Page 2 of 138

June 4, 1901

\section{Section 1; RSP 90-007-1 Radiation Surveys}

Radiation surveys will be performed in the $105 \mathrm{~K}$ Building at the following times:

1) Before startup to provide baseline measurement

2) At $75 \mathrm{MW}$ during the initial power ascension

3) At $90 \%$ power during the initial power ascension

4) During full power operation, after one month of full power production operation.

Acceptance Criteria: No radiation readings will exceed current postings in the following areas:

Clean areas

Radiation areas

High radintion areas

Very high radiation areas

Contamination areas

Airborne radioactivity areas

References: Restart Test Identification Reoont *4. K-Reactor Power Ascension (U), WSRC-TA-90-29-004K, Outline \#1, Novermber 7, 1990.

DPSOP 40-1, Rov. 24, SRP Radiation and Contarnination Control.

DPSOL 193-118, Radiological Posting. 
WSRC-TR-91-42-043

Page 3 of 138

June 4, 1991

Section 2: RSP 90-007-2 Safety Rod System Tesing

This test will functionally test the safety rod system to verify operability and safety rod insertion timing.

Acceptance Criteria: Limits as defined in the following DPSOLs:

DPSOL 105-1218 Safety Rod Snubbing Height Test

DPSOL 105-1046D Nuclear Startup - Raisine Safety Rods

- Manual Centrol: Section B - Safety Rod Drop Test

DPSOL 105-1863A Safety Rod Insertion Time

Determination

DPSOL 105-1213 Safety Rod Snubber Deformation Test

DPSOL 105-1046H and I Nuclear Startup - Data Operator

Duties, Soction B - Raising Safety Rods

References: Restart Test Identification Report \#4, K-Reactor Power Ascension (U). WSRC-TR-90-29-004K, Outline \#2, November 7, 1990.

DPSOL 105-1218 Safety Rod Snubbing Height Test

DPSOL 105-1046D Nuclear Startup - Raising Safety Reds - Manual

Control Section B - Safety Rod Drop Test

DPSOL 105-1863A Safety Rod Insertion Time Determination

DPSOL 105-1213 Safety Rod Snubber Deformation Test

DPSOL 105-1046H and I Nuciear Startup-Data Operator Duties, Section B - Raising Safety Rods 
WSRC-TR-91-42-043

Pago 4 of 138

June 4, 1991

\section{Section 3: RSP 90-007-3 Initial Critical}

The primary objective is to start up the reactor, approaching critical in a slow, cautious, and deliberate manner. After the reactor is critical, the reactor will be operated in the $40 \mathrm{KW}$ to $120 \mathrm{KW}$ power range to determine the stability of the reactor at this low power.

Predictions: Estimated Critical Position - $2260 \mathrm{vu}$

Acceptance Criteria: Allowable insertion limits for approach to criticality and operator actions if limits are exceeded are described in DPSOL 105-1060, Charge Reactivity Assessment.

Limits for critical position

Maximum Insertion at Critical - 3275 vu

High Critical Position - 2615 vu

Low Critical Position - 1650 wu

Minimum Insertion at Critical - $1170 \mathrm{vu}$

References: Restart Test Identification Report *4. K-Reactor Power Ascension (U), WSRC-TR-90-29-004K, Outline *3, February 21, 1991.

Swingle, R. F., Core Operations Report - Physics, RTM-5000-K-14-1, June 1991. 
WSRC-TR-91-42-043

Page 5 of 138

June 4, 1991

Section 4: RSP 90-007-4 Reactivity Computer Calibration

This test will be performed while the reactor is at zero poiver (40 to $120 \mathrm{KW}$ range) to verify that the reactivity computer is properly calculating reactivity changes.

Reactivity changes of $20 \mathrm{pcm}$ and $45 \mathrm{pcm}$ (percent millirho or $10^{-5} \Delta \mathrm{k} / \mathrm{k}$ eff) will be made. The reactivity change calculated by the computer in real time will be compared to the reactivity change calculated by the inhour equation using a known reactor period. Given the rate of change in neutron flux, the reactivity computer calculates reactivity with the inverse kinetics equation. The inhour equation is a stitic calculation using the reactor period to calculate reactivity.

Acceptance Criteria: Deviation between reactivity value from reactivity computer and reactivity value from measured period is $5 \%$ or less.

References: Restart Test Identification Report *4, K-Reactor Power Ascension (U), WSRC-TR-90-29-004K, Outline \#4, Fobruary 6, 1991. 
WSRC-TR-91-42-043

Page 6 of 138

June 4, 1991

\section{Section 5: RSP 90-007-5 Differential Control Rod Worth}

A differential control rod worth is defined as the reactivity change from a steady state caused by the movement of a control gang. This test will be performed at zero power and the reactivity computer will be used to measure the effect of moving individual control rod gangs. The measurement of the reactivity changes associated with control rod gang moves with the reactivity computer will provide data to validate and improve the predicted control rod worth curves for the Mark 22 charge. Differential measurements will be performed with the following partial rod complements:

1) Double partial control rods at $800 \mathrm{vu}$

2) Double partial control rods at $950 \mathrm{vu}$

3) Double partial control rods at $700 \mathrm{vu}$

4) Weak partial control rods at $800 \mathrm{vu}$

5) Weak partial control rods at $950 \mathrm{vu}$

6) Weak partial control rods at $700 \mathrm{vu}$

Predictions: Critical rod positions for the cases 2 - 6 are determined using Figures $1-6$ and the known critical rod position for double partial rods at $800 \mathrm{vu}$. Once the critical rocs position is known during the first startup, the relative critical eigenvalue determined on Figure 1 will be used to determine the predicted critical rod position for the other cases (Figures 2 - 6) with different partial rod complements and locations.

Figures 7 - 12 describe the reactivity change caused by a 50 vu full control rod gang withdrawal. The maximum full rod gang withdrawal specified in RSP 90-007-5 will be 50 vu. These figures will be used if only a 50 vu full rod withdrawal must be made.

Expected gang full rod moves to obtain 10,20, and $30 \mathrm{pcm}$ reactivity changes have been calculated based on full rod positions (Figures 13 - 51).

Acceptance Criteria: For the measurements performed with the partial rods at $800 \mathrm{vu}$ (both doubles and weaks), the reactivity changes as measured by the reactivity computer stiould be within $30 \%$ of the expected reactivity value. No acceptance criteria are provided for the cases with partial rods at 700 $\mathrm{vu}$ and $950 \mathrm{vu}$ because rod worth curves are specifically calculated for partial rods located at $800 \mathrm{vu}$. Data with the partial rods at other axial positions will be used to validate and improve control rod worth curves over an extended range.

The critical rod positions for the cases 2 - 6 will be within $\pm 0.0071 \Delta k$ of the critical position predicted frori figures $1-6$ after the first nuclear startup. 
WSRC-TR-91-42-043

Page 7 of 138

June 4, 1991

Section 5: (cont)

References: Restart Test Identification Repent \#4.K-Reactor Power Ascension (U). WSRC-TR-90-29-004K, Outline \#5, February 5, 1991.

Bond, R. A., Calculations for Control Rod Worth Measurements Durino K Reactor Startup and Power Ascension (U) WSRC-TR-9142-044, June 1991.

Rosser, M. A., Mark 22 Initial Critical Rod Worth Cunves (U), WSRCTR-91-42-033, May 1991.

Zino, J. F. and Nadeau, M. L, Reactivity Assessment Manual - Mark 22 Charae, WSRC-TR-90-42-057, Rev. 1. June 25, 1990. 
WSRC-TR-91-42-043

Page 8 of 138

June 4, 1991

Section 6: RSP 90-007-6 Detect Unlatched Centrol Rod with Reactivity Computer

No quantitative acceptance criteria or expectation values for this test.

\section{Section 7: RSP 90-007-7 Single Partial Rod Insertion at Zero Power}

This test will be performed at zero power to provide baseline data on the reactivity change caused by the insertion of a partial rod from its demand position to full in. The information will be used to analyze the dropped partial rod accident. The strong partial and weak partial rod will be individually inserted in the following clusters:

Cluster 1 - strong partial (rod F), weak partial (rod C)

Cluster 36 - strong partial (rod E), weak partial (rnd B)

Cluster 52 - strong partial (rod C), weak partial (rod F)

Predictions: Expected reactivity changes caused by the insertion of single partial rods from 800 vu to 1000 vu for given full rod positions are shown in Figures $52-57$.

Acceptance Criteria: The reactivity changes as measured by the reactivity computer stiould be within the maximum and minimum ranges of the expected reactivity values (Figures 52-57). Reactivity worth of single partial rods will be verified to be less than $11.3 \mathrm{pcm}$, which is determined to be the maximum worth of a partial rod insertion incident in the Safety Analysis Report.

References: Restart Test Identification Report \#4, K-Reactor Power Ascension (U), WSRC-TR-90-29-004K, Outline \#7, February 7, 1991.

Bond, R. A., Calculations for Control Rod Worth Measurements During K Reactor Startup and Power Ascension (U), WSRC-TR-9142-044, June 1991.

Final Draft Non-LOCA Sections for K Restart SAR. Chapter 15 (U), SRL-SAG-900551. 


\section{PREDICTIONS AND ACCEPTANCE CRITERIA FOR K REACTOR STARTUP AND POWER ASSENSION (U)}

by

R. A. Bond, Jr.

Westinghouse Savannah River Company

Savannah River Site

Aiken, South Carolina 29808

$$
\begin{aligned}
& \text { Prenom Uol } \\
& \text { IUL. a } 1992
\end{aligned}
$$

The information contained in this document was prepared in connection with work done under Contract No. DE-AC09-89SR 18035 with the U.S. Department of Energy. By acceptance of this report, the publisher and/or recipient acknowledges the U.S. Governmeni's right to retain a nonexclusive, royalty-free license in and to any copyrighe covering this report, along with the right to reproduce and to authorize others to reproduce all or part of the copyrighted report. 


\section{DISCLAIMER}

This report was prepared as an account of work sponsored by an agency of the United States Government. Neither the United States Government nor any agency thereof, nor any of their employees, makes any warranty, express or implied, or assumes any legal liability or responsibility for the accuracy, completeness, or usefulness of any information, apparatus, product, or process disclosed, or represents that its use would not infringe privately owned rights. Reference herein to any specific commercial product, process, or service by trade name, trademark, manufacturer, or otherwise does not necessarily constitute or imply its endorsement, recommendation, or favoring by the United States Government or any agency thereof. The views and opinions of authors expressed herein do not necessarily state or reflect those of the United States Government or any agency thereof.

This report has been reproduced directly from the best available copy.

Available to DOE and DOE contractors from the Office of Scientific and Technical Information, P.O. Box 62, Oak Ridge, TN 37831; prices available from (615) 576.8401, FTS 626-8401.

Available to the public from the National Techncial Information Service, U.S. Department of Commerce, 5285 Port Royal Rd., Springfield, VA 22161. 


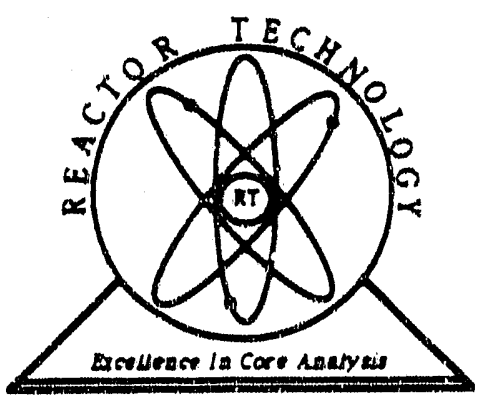

WSRC-TR-91-42-043

DOES NOT CONTAN

UNCLASSIFED CONTROLLED

NUCLEAR NFORMATION

\section{PREDICTIONS AND ACCEPTANCE CRITERIA FOR K REACTOR STARTUP AND POWER ASCENSION (U)}

BY:

R. A. BOND, JR.

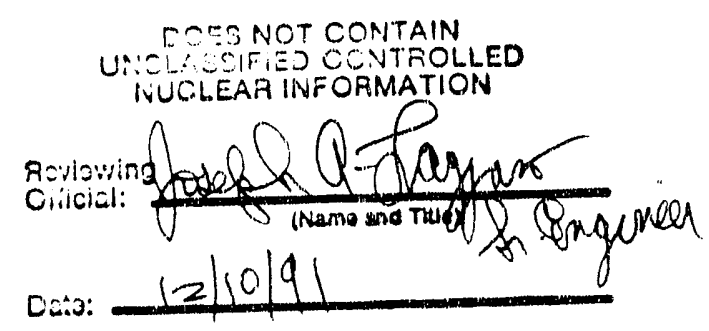

JUNE 1991

REACTOR TECHNOLOGY SECTION REACTOR ENGINEERING DEPARTMENT

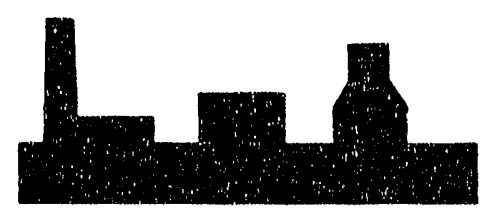


DOES NOT CONTAIN

UNCLASSIFIED CONTROULED

NUCLEAR INFORMATION

Reviewing

Official:

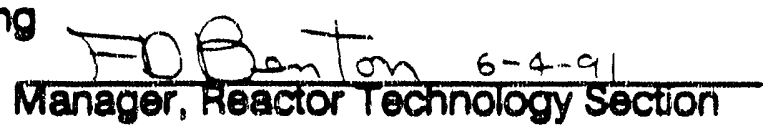

KEYWORDS:

STARTUP TESTING

K-14 MARK 22 CHARGE

POWER ASCENSION

ZERO POWER

ACCEPTANCE CRITERIA

RETENTION:

PERMANENT

CLASSIFICATION:

Unclassified

Authorized Derivative Classifier

\section{PREDICTIONS AND ACCEPTANCE CRITERIA FOR K REACTOR STARTUP AND POWER ASCENSION (U)}

BY:

R. A. BOND, JR.

ISSUED: June 4, 1991

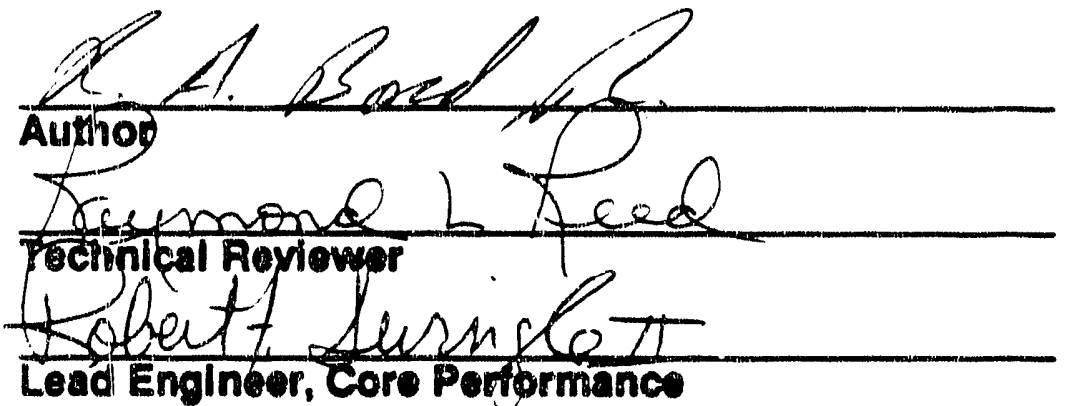

Mare Rosser Manager, Core Phyalca Manager, Reactor Tochnology
DATE: $6 / 4 / 91$

DATE: $6-4-91$ DATE: $6 / 4 / 91$ DATE: $6 / 4 / 9 /$ DATE: $6-4-91$ 
WSRC-TR-91-42-043

Page 1 of 138

June 4, 1991

PREDICTIONS AND ACCEPTANCE CRITERIA FOR K FIEACTOR STARTUP AND POWER ASCENSION (U)

\section{INTRODUCTION}

The master procedure to startup K Reactor is RSP 90-007. Within this procedure are 16 separate tests to verify that the reactor will be operated within the parameters described in the Safety Analysis Report (SAR), Safety Evaluation Report (SER), and Technical Specifications. Several of these tests will provide data to benchmark reactor physics computer codes that are used in core design and safety analysis. RSP 90-007 applies acceptance criteria or expectation ranges to results of measurernents performed in each test. Calculations for the predictions have been performed by various members of Reactor Technology in the Reactor Engineering Department and Reactor Physics of Savannah River Laboratory. This technical report combines all predictions and acceptance criteria into one document.

\section{SUMMARY}

The purpose of this report is to consolidate all the work performed on the predictions and acceptance criteria for the K Reactor Startup and Power Ascension Test Program. All results reported in this document are referenced to technical documents. This report consolidates the results of several technical reports previously issued. The technical background of the results can be found in the references given in this document.

\section{DISCUSSION}

This discussion briefty describes the predictions and acceptance criteria of each test. The individual tests are discussed and referenced separately. 
WSRC.TR- $91-42-043$

Page 2 of 138

June 4, 1901

\section{Section 1; RSP 90-007-1 Radiation Surveys}

Radiation surveys will be performed in the $105 \mathrm{~K}$ Building at the following times:

1) Before startup to provide baseline measurement

2) At $75 \mathrm{MW}$ during the initial power ascension

3) At $90 \%$ power during the initial power ascension

4) During full power operation, after one month of full power production operation.

Acceptance Criteria: No radiation readings will exceed current postings in the following areas:

Clean areas

Radiation areas

High radintion areas

Very high radiation areas

Contamination areas

Airborne radioactivity areas

References: Restart Test Identification Reoont *4. K-Reactor Power Ascension (U), WSRC-TA-90-29-004K, Outline \#1, Novermber 7, 1990.

DPSOP 40-1, Rov. 24, SRP Radiation and Contarnination Control.

DPSOL 193-118, Radiological Posting. 
WSRC-TR-91-42-043

Page 3 of 138

June 4, 1991

Section 2: RSP 90-007-2 Safety Rod System Tesing

This test will functionally test the safety rod system to verify operability and safety rod insertion timing.

Acceptance Criteria: Limits as defined in the following DPSOLs:

DPSOL 105-1218 Safety Rod Snubbing Height Test

DPSOL 105-1046D Nuclear Startup - Raisine Safety Rods

- Manual Centrol: Section B - Safety Rod Drop Test

DPSOL 105-1863A Safety Rod Insertion Time

Determination

DPSOL 105-1213 Safety Rod Snubber Deformation Test

DPSOL 105-1046H and I Nuclear Startup - Data Operator

Duties, Soction B - Raising Safety Rods

References: Restart Test Identification Report \#4, K-Reactor Power Ascension (U). WSRC-TR-90-29-004K, Outline \#2, November 7, 1990.

DPSOL 105-1218 Safety Rod Snubbing Height Test

DPSOL 105-1046D Nuclear Startup - Raising Safety Reds - Manual

Control Section B - Safety Rod Drop Test

DPSOL 105-1863A Safety Rod Insertion Time Determination

DPSOL 105-1213 Safety Rod Snubber Deformation Test

DPSOL 105-1046H and I Nuciear Startup-Data Operator Duties, Section B - Raising Safety Rods 
WSRC-TR-91-42-043

Pago 4 of 138

June 4, 1991

\section{Section 3: RSP 90-007-3 Initial Critical}

The primary objective is to start up the reactor, approaching critical in a slow, cautious, and deliberate manner. After the reactor is critical, the reactor will be operated in the $40 \mathrm{KW}$ to $120 \mathrm{KW}$ power range to determine the stability of the reactor at this low power.

Predictions: Estimated Critical Position - $2260 \mathrm{vu}$

Acceptance Criteria: Allowable insertion limits for approach to criticality and operator actions if limits are exceeded are described in DPSOL 105-1060, Charge Reactivity Assessment.

Limits for critical position

Maximum Insertion at Critical - 3275 vu

High Critical Position - 2615 vu

Low Critical Position - 1650 wu

Minimum Insertion at Critical - $1170 \mathrm{vu}$

References: Restart Test Identification Report *4. K-Reactor Power Ascension (U), WSRC-TR-90-29-004K, Outline *3, February 21, 1991.

Swingle, R. F., Core Operations Report - Physics, RTM-5000-K-14-1, June 1991. 
WSRC-TR-91-42-043

Page 5 of 138

June 4, 1991

Section 4: RSP 90-007-4 Reactivity Computer Calibration

This test will be performed while the reactor is at zero poiver (40 to $120 \mathrm{KW}$ range) to verify that the reactivity computer is properly calculating reactivity changes.

Reactivity changes of $20 \mathrm{pcm}$ and $45 \mathrm{pcm}$ (percent millirho or $10^{-5} \Delta \mathrm{k} / \mathrm{k}$ eff) will be made. The reactivity change calculated by the computer in real time will be compared to the reactivity change calculated by the inhour equation using a known reactor period. Given the rate of change in neutron flux, the reactivity computer calculates reactivity with the inverse kinetics equation. The inhour equation is a stitic calculation using the reactor period to calculate reactivity.

Acceptance Criteria: Deviation between reactivity value from reactivity computer and reactivity value from measured period is $5 \%$ or less.

References: Restart Test Identification Report *4, K-Reactor Power Ascension (U), WSRC-TR-90-29-004K, Outline \#4, Fobruary 6, 1991. 
WSRC-TR-91-42-043

Page 6 of 138

June 4, 1991

\section{Section 5: RSP 90-007-5 Differential Control Rod Worth}

A differential control rod worth is defined as the reactivity change from a steady state caused by the movement of a control gang. This test will be performed at zero power and the reactivity computer will be used to measure the effect of moving individual control rod gangs. The measurement of the reactivity changes associated with control rod gang moves with the reactivity computer will provide data to validate and improve the predicted control rod worth curves for the Mark 22 charge. Differential measurements will be performed with the following partial rod complements:

1) Double partial control rods at $800 \mathrm{vu}$

2) Double partial control rods at $950 \mathrm{vu}$

3) Double partial control rods at $700 \mathrm{vu}$

4) Weak partial control rods at $800 \mathrm{vu}$

5) Weak partial control rods at $950 \mathrm{vu}$

6) Weak partial control rods at $700 \mathrm{vu}$

Predictions: Critical rod positions for the cases 2 - 6 are determined using Figures $1-6$ and the known critical rod position for double partial rods at $800 \mathrm{vu}$. Once the critical rocs position is known during the first startup, the relative critical eigenvalue determined on Figure 1 will be used to determine the predicted critical rod position for the other cases (Figures 2 - 6) with different partial rod complements and locations.

Figures 7 - 12 describe the reactivity change caused by a 50 vu full control rod gang withdrawal. The maximum full rod gang withdrawal specified in RSP 90-007-5 will be 50 vu. These figures will be used if only a 50 vu full rod withdrawal must be made.

Expected gang full rod moves to obtain 10,20, and $30 \mathrm{pcm}$ reactivity changes have been calculated based on full rod positions (Figures 13 - 51).

Acceptance Criteria: For the measurements performed with the partial rods at $800 \mathrm{vu}$ (both doubles and weaks), the reactivity changes as measured by the reactivity computer stiould be within $30 \%$ of the expected reactivity value. No acceptance criteria are provided for the cases with partial rods at 700 $\mathrm{vu}$ and $950 \mathrm{vu}$ because rod worth curves are specifically calculated for partial rods located at $800 \mathrm{vu}$. Data with the partial rods at other axial positions will be used to validate and improve control rod worth curves over an extended range.

The critical rod positions for the cases 2 - 6 will be within $\pm 0.0071 \Delta k$ of the critical position predicted frori figures $1-6$ after the first nuclear startup. 
WSRC-TR-91-42-043

Page 7 of 138

June 4, 1991

Section 5: (cont)

References: Restart Test Identification Repent \#4.K-Reactor Power Ascension (U). WSRC-TR-90-29-004K, Outline \#5, February 5, 1991.

Bond, R. A., Calculations for Control Rod Worth Measurements Durino K Reactor Startup and Power Ascension (U) WSRC-TR-9142-044, June 1991.

Rosser, M. A., Mark 22 Initial Critical Rod Worth Cunves (U), WSRCTR-91-42-033, May 1991.

Zino, J. F. and Nadeau, M. L, Reactivity Assessment Manual - Mark 22 Charae, WSRC-TR-90-42-057, Rev. 1. June 25, 1990. 
WSRC-TR-91-42-043

Page 8 of 138

June 4, 1991

Section 6: RSP 90-007-6 Detect Unlatched Centrol Rod with Reactivity Computer

No quantitative acceptance criteria or expectation values for this test.

\section{Section 7: RSP 90-007-7 Single Partial Rod Insertion at Zero Power}

This test will be performed at zero power to provide baseline data on the reactivity change caused by the insertion of a partial rod from its demand position to full in. The information will be used to analyze the dropped partial rod accident. The strong partial and weak partial rod will be individually inserted in the following clusters:

Cluster 1 - strong partial (rod F), weak partial (rod C)

Cluster 36 - strong partial (rod E), weak partial (rnd B)

Cluster 52 - strong partial (rod C), weak partial (rod F)

Predictions: Expected reactivity changes caused by the insertion of single partial rods from 800 vu to 1000 vu for given full rod positions are shown in Figures $52-57$.

Acceptance Criteria: The reactivity changes as measured by the reactivity computer stiould be within the maximum and minimum ranges of the expected reactivity values (Figures 52-57). Reactivity worth of single partial rods will be verified to be less than $11.3 \mathrm{pcm}$, which is determined to be the maximum worth of a partial rod insertion incident in the Safety Analysis Report.

References: Restart Test Identification Report \#4, K-Reactor Power Ascension (U), WSRC-TR-90-29-004K, Outline \#7, February 7, 1991.

Bond, R. A., Calculations for Control Rod Worth Measurements During K Reactor Startup and Power Ascension (U), WSRC-TR-9142-044, June 1991.

Final Draft Non-LOCA Sections for K Restart SAR. Chapter 15 (U), SRL-SAG-900551. 
WSRC-TR-91-42-0.43

Page 9 of 138

June 4, 1981

\section{Section 8: ASP 90-007-8 Power Coefficient Data - Power Ascransion}

This test will assess the temperature and fission product reactivity feedback components as power is increased. Power level's for $K$ Reactor will be as follows:

zero power $(40 \mathrm{KW}-120 \mathrm{~kW})$

Low power ( $75 \mathrm{MW}$ )

$20 \%, 40 \%, 60 \%, 90 \%$, and $100 \%$ of current full power.

Reactivity effects of temperature and fission productis will be determined using control rod positions and rod worth curves.

Predictions: Expected reactivity changes caused by temperature change aus power is increased are shown in Figures 58 and 59 . Figure 5.9 is used to deternine the change in reactivity for a change in power from one powar level to the next. The expected reactivity changes caused by fission product build-in during power ascension are shown in Tables 1 and 2. The expected reactivity changes caused by combined temperature and fission product effects are shown in Tables 3 and 4.

The fission product build-in shown in Tablos 1 - 4, assume that the reactor is maintained at $20 \%, 40 \%$, and $90 \%$ powers for 48 hours. Tables 1 and 3 assume that the reactor is operated at $60 \%$ power for one week for testing (Tests 10,11, 12, and 14). Tables 2 and 4 assume the reactor is operated at $60 \%$ power for three weeks.

Acceptance Criteria: The reactivity changes as determined by control rod positions and rod worth curves should be within the maximum and minimum ranges of the expocted reactivity values (Figures 58 and 59, and Tables 3 and 4).

References: Restart Test Identification Repert 4, K-Beactor Power Ascension (U), WSRC-TR-90-29-004K, Outline \#B, November 7, 1991.

Bond, R. A. Calculations for Control Rod Worth Measurements During KReactor Starturand Power Ascension (U) WSRC-TR-9142-044, June 1991.

Henrikson, D. J., Fission Product Reactivity for Initial K-14 Power Ascension (U), RRD-RTS-910177, June 1991.

Fosser, M. A. Mark 22 Initial Critical Rod Worth Cl ines (U), WSRCTR-91-42-033, May 1991.

Swingle, R. F., At-Power and Becovery Startup Control Rod W'orth Cunes for The K-14-1 Subeycle (U), WSRC-TR-91-42-046, May 30, 1991.

Rosser, M. A., Predictina $\mathrm{k}$ Held in Temperature For K Reactor Mark 22 Charoes (U), WSRC-TR-90-42-120, October 22, 1990. 
WSRC-TR-91-42-043

Page 10 of 138

June 4, 1991

Section 9: BSP 90-007-9 Radial and Axial Power Distributions

At each power level from $75 \mathrm{MW}$ and up, measurements of the radial and axial power' shape will be made with the control computer. At $20 \%$ power with all full rods at the same insertion and double partial rods at $800 \mathrm{vu}$, radial and axial power shapes will be compared to calculated shapes. The $20 \%$ power level was chosen for radial and axial shape comparisons because the power will be low enough that full rods and partial rods can still be maintained at the same insertion in each gang and satisfy Tech Spec limits on power shapes. As power is increased above $20 \%$, control rods will be adjusted to maintain the ractial and axial power shapes within procedural limits. Determir tions of reactivity held in control rods before and after power shape flattening at tach power level will bo made using control rod worth curves.

Predictions: Expected normalized and gang averaged radial power shapes based on full rod positions at $20 \%$ power are shown in Table 5. Exnacted normalizgd axial power shapes based on full rod positions - J\% power are shown in Table 6.

Acceptance Criteria: The redial power will be normalized to gang 1 average power as determined by gang averaged power from the control computer (program 22). For a given full rod position, the radial power distribution should be within the limits shown in Table 5. The limits are defined as $\pm 10 \%$ of the normalized radial power for gangs 1 and 2 and $\pm 20 \%$ of the normalized radial power for gang 3 and the buckled zone.

The normalized axial power shape as determined by the control computer (programs 15 and 40 ) should be within the limits given in table 6 . The limits are defined as $\pm 35 \%$ of the normalized axial power shape for the given full rod position.

The allowable difference in reactivity worth held in control rods before and after flattening is $0.005 \Delta \mathrm{k} / \mathrm{k}_{\text {eff }}$.

References: Restart Test Idertification Report *4. K-Reactor Power Ascension (U), WSRC-TR-90-29-004K, Outline *9, November 7, 1991.

Bond, R. A., Calculations for Control Rod Worth Measurements During K Peactor Startup and Power Ascension (U), WSRC-TR-91. 42-044, Jine 1991.

Losey, $D$ Axial Power Shape Prodictions for $K-14$ Startup (U), WSRC-Tr-91-42-047, June 1991.

Rosser, M. A., Mark 22 Initial Critical Red Worth Cunes (U), WSRCTR-91-42-033, May 1991. 
WSRC-TR- $91-42-043$

Page 11 of 138

June 4, 1991

Section 9: (cont)

References: Swingle, R. F., At-Power and Becovery Startup Control Rod Worth Curves for The K-14-1 Subercle (U), WSRC-TR-91-42-046, May 30, 1991.

Losey, D. C., Limiting Axial Flux Shapes and Rod Worth Curves (U), RRD-RTS-910175, May 31, 1981. 
WSRC-TR-91-42-043

Page 12 of 138

June 4, 1991

\section{Section 10: RSP 90-007-10 Integral Rod insertion at 60\% Power}

This test will provide information for the analysis of the single rod withdrawal accident. The measurements will provide data about the reactivity change for an integral rod and an associated power perturbation. The change in reactivity will be measured using full control rod positions and control rod worth curves. The strong lithium $(2.02 \mathrm{gm} / \mathrm{ft} \mathrm{L}-6)$ full control rod will be inserted as an integral rod in the following clusters:

Cluster 3 - Control rod C

Cluster 20 - Control rod A

Cluster 54 - Control rod E

Predictions: Expected reactivity changes caused by the insertion of a single integral rod are shown in Figures 60 - 64.

The rod configuration used for these predictions assume that with double partial rods at $800 \mathrm{vu}$, the gang 3 full rods will probably be at $100 \mathrm{vu}$. Calculations indicate for a radially flattened power shape gang 3 full rods will be at $100 \mathrm{vu}$, which is the minimum insertion for full control rods. Other calculations were performed to show the effects of gang 3 full rods being located at $450 \mathrm{vu}$ and $1000 \mathrm{vu}$. The calculations primarily studied the effects of gang 1 and gang 2 full rod positions. The prediction made for the insertion of an integral rod in gang 3 is dependent on the gang 2 full rod position with gang 3 full rods at $100 \mathrm{vu}, 450 \mathrm{vu}$, or $1000 \mathrm{vu}$. If the gang 3 full rods are not at these full rod locations, interpolation between the curves may have to be required.

Acceptance Criteria: There are no acceptance criteria for this test.

The change in reactivity as measured by control rod positions before and after the insertion of the single integral control rod should be within the range shown in Figures $60-64$.

If the measured values are outside the expected range, an assessment will be made before continuing to next test. The expecied values are based on the assumption that the double partial rods are located at $800 \mathrm{vu}$. If the power shape limits do not permit the control rod configuration used in the predictions, the measurements will probably not be within the ranges defined for this test. 
WSRC-TR-91-42-043

Page 13 of 138

June 4, 1991

Section 10:(contu)

References: Restart Test identification Report * 4. K-Reactor Power Ascension (U). WSRC-TR-90-29-004K, Outtine \# 10, December 12, 1990.

Bond, R. A., Calculations for Control Rod Worth Measurements Durino K Reactor Startup and Power Ascension (U), WSRC-TR-9142-044, June 1991.

Rosser, M. A., Mark 22 Initial Critical Bod Werth Curves (U), WSRCTR-91-42-033, May 1991.

Swingle, R. F., At-Power and Recovery Startup Control Rod Worth cunves for The $\mathrm{K}-14-1$ Subcycle (U), WSRC-TR-91-42-046, May 30 , 1091. 
WSRC-TR-91-42-043

Page 14 of 138

June 4, 1991

\section{Section 11: RSP 90-007-11 Single Partial Rod insertion at 60\% Power}

This test will provide baseline data on the reactivity worth and power distribution perturbation associated with the insertion of a single partial rod from its demand position to full in. The information will be used to analyze the dropped partial rod accident. This test will use same partial rods used in test 7.

Predictions: Expected reactivity changes caused by the insertion of a single partial control rod are shown in Figures 65 - 82.

The rod configuration used for these predictions assume that with double partial rods at $800 \mathrm{vu}$, the gang 3 full rods will probably be at $100 \mathrm{vu}$. Calculations indicate for a radially flattened power shape gang 3 full rods will be at $100 \mathrm{vu}$, which is the minimum insertion for full control rods. Other calculations were performed to show the effects of gang 3 full rods being located at $450 \mathrm{vu}$ and $1000 \mathrm{vu}$. The calculations primarily studied the effects of gang 1 and gang 2 full rod positions. The predictions made for the insertion of single partial rods in gang 3 are dependent on the gang 2 full rod position with gang 3 full rods at $100 \mathrm{vu}, 450 \mathrm{vu}$, or $1000 \mathrm{vu}$. If the gang 3 full rods are not at these full rod locations, interpolation between the curves may have to be required.

Acceptance Criteria: There are no acceptance criteria for this test.

The change in reactivity as measured by control rod positions before and after the insertion of the single partial control rod should be within the range shown in Figures 65 - 82. Reactivity worth of single partial rods will be verified to be less than $113 \mathrm{pcm}$, which is determined to be the maximum worth of a partial rod insertion incident in the Safety Analysis Report.

If the measured values are outside the expected range, an assessment will be made before continuing to next test. The expected values are based on the assumption that the double partial rods are located at $800 \mathrm{vu}$. If the power shape limits do not permit the control rod configuration used in the predictions, the measurements will probably not be within the ranges defined for this test. 
WSRC-TR- $91-42-043$

Page 15 of 138

June 4, 1991

Section 11: (cont)

References: Restart Test Identification Repert *4. K-Reactor Power Ascension (U), WSRC-TR-90-29-004K, Outline \#11, December 20, 1990.

Bond, R. A., Calculations for Control Rod Worth Measurements

Durino K Reactor Startup and Power Ascension (U). WSRC-TR-9142-044, June 1991.

Rosser, M. A., Mark 22 Initial Critical Rod Worth Cunes (U), WSRCTR-91-42-033, May 1991.

Swingle, R. F., At-Power and Recovery Startue Control Rod Worth Cunves for The K-14-1 Subeycle (U), WSRC-TR-91-42-046, May 30, 1991.

Final Draft Non-LOCA Sections for K Restart SAR. Chapter 15 (U)), SRL-SAG-900551. 
WSRC-TR-91-42-043

Page 16 of 138

June 4, 1991

\section{Section 12: RSP 90-007-12 Partial Rod Gana Positioning}

This test will provide baseline data on the reactivity effect and power distribution perturbation caused by the insertion of a partial rod gang $50 \mathrm{vu}$ from its normal demand position.

Predictions: Expected reactivity changes caused by the insertion of a double partial control rod gang are shown in Figures 83 - 91.

The rod configuration used for these predictions assume that with double partial rods at $800 \mathrm{vu}$, the gang 3 full rods will probably be at $100 \mathrm{vu}$. Calculations indicate for a radially flattened power shape gang 3 full rods will be at 100 vu, which is the minimum insertion for full control rods. Other calculations were performed to show the effects of gang 3 full rods being located at $450 \mathrm{vu}$ and $1000 \mathrm{vu}$. The calculations primarily studied the effects of gang 1 and gang 2 full rod positions. The prediction made for the insertion of the double partial rod gang in gang 3 is dependent on the gang 2 full rod position with gang 3 full rods at $100 \mathrm{vu}, 450 \mathrm{vu}$, or $1000 \mathrm{vu}$. If the gang 3 full rods are not at these full rod locations, interpolation between the curves may have to be required.

Acceptance Criteria: There are no acceptance criteria for this test.

The change in reactivity as measured by control rod positions before and after the insertion of a double partial control rod gang should be within the range shown in Figures $83-91$.

If the measured values are outside the expected range, an assessment will be made before continuing to next test. The expected values are based on the assumption that the double partial rods are located at $800 \mathrm{vu}$. If the power shape limits do not permit the control rod configuration used in the predictions, the measurements will probably not be within the ranges defined for this test.

References: Restart Test Identification Report \#4, K-Reactor Power Ascension (U), WSRC-TR-90-29-004K, Outline \#12, January 23, 1991.

Bond, R. A., Calculations for Control Rod Worth Measurements Durino $K$ Reactor Startuo and Power Ascension (U), WSRC-TR-9142-044, June 1991.

Rosser, M. A., Mark 22 Initial Critical Roo Worth Curves (U), WSRCTR-91-42-033, May 1991.

Swingle, R. F., At-Power and Recovery Startuo Control Rod Worth Curves for The K-14-1 Subeycle (U), WSRC-TR-91-42-046, May 30, 1991. 
WSRC-TR-91-42-043

Page 17 of 138

June 4, 1991

RSP 90-007-13 (Test deleted by Startup Testing Review Committe日)

Section 13: RSP 90-007-14 Axial Power Monitor (APM) - Travelling Wire Flux Monitor (TWFM) Comparison

This test will collect data for an analysis assessing the response of the new Axial Power Monitor (APM) Rods. Axial power measurements with the APM rods will be compared with axial neutron flux measurements taken with the Travelling Wire Flux Monitor (TWFM).

Acceptance Criteria: The weighted variance between the normalized data from each TWFM trace and the ncrmalized data from the corresponding APM rod should be less than 0.1 (10\%).

Power cannot be increased above the Power Shape Applicability Limit (PSAL) if the deviations exceed $10 \%$ until the discrepancy has been resolved.

References: WSRC-TR-90-29-004K, Restart Test Identification Report \#4, KReactor Power Ascension (U), Outline \#14, January 17, 1991.

Losey, D. C., Startup Testing of New APM Rods (U), OPS-RTS900093, July 1990.

Vescovi, P. J., Acceptance Criteria for Axial Power Monitor (APM) Iestine(U), RRD-RTS-910090, Rev. 1, April 19, 1991. 
WSRC-TR-91-42-043

Page 18 of 138

June 4, 1991

Section 14: RSP 90-007-15 Safety Rod SCRAM Via Remote Monitoring and control System (REMACS)

This test will dernonstrate the capability of the REMACS system to remotely shut down K Reactor and demonstrate the shutdown capability of the safety rod system. Comparisons will be made of the relative neutron flux shape during the SCRAM with predictions based on safety rod worth used in the Safety Analysis Report.

Predictions: Expected decrease in relative flux caused by a safety rod SCRAM is shown in Figure 92.

Acceptance Criteria: The observed relative flux as measured by neutron flux detectors will decrease greater and quicker than prediction shown in Figure 92.

References: Restart Test Identification Report * 4, K-Reactor Power Ascension (U), WSRC-TR-90-29-004K, Outline \#11, January 22, 1991.

Wallace, J. M., AA3 Analyses for the Safety Rod SCRAM Tests

During K-14 Startup Testing Prooram (U), RRD-RTS-910074, February 8, 1991. 
WSRC-TR-91-42-043

Page 19 of 138

June 4, 1991

\section{Section 15: RSP 90-007-16 Control Rod Worth During Xenon Transient}

This test will measure the differential control rod worths by following the xenon build-in and decay from a reactor shutdown. This test will require the reactor to be started up shorty after it has been shutdown to allow for measurements to be made while the xenon is changing. This test will provide more information on the worth of the control rods because larger axial distances will be covered by the control rods than during the tests performed at initial startup. The xenon reactivity worth can be assessed from the results of this test.

Predictions: Xenon decay curves for shutdowns from various equilibrium power levels a, $\theta$ given in Figures 93 - 107.

Acceptance Criteria: The ECP requiremerits in DPSOL 105-1060A for shutdown recovery must be met.

References: Restant Test Identification Repent \#4,K-Reactor Power Ascension (U), WSRC-TR-90-29-004K, Outline \#16, January 22, 1991.

Bond, A. A., Calculations for Control Pod Worth Measurements

During K Reactor Startup and Power Ascension (U). WSRC-TR-91. 42-044, June 1991.

Rosser, M. A., Mark 22 Initial Critical Rod Worth Curves (U), WSRCTR-91-42-033, May 1991.

Swingle, R. F., At-Power and Recovery Startuo Control Rod Worth Cunes for The K-14-1 Subcycle (U), WSRC-TR-91-42-045, May 30, 1991. 
WSRC-TR-91-42-043

Page 20 of 138

June 4, 1991

Section 16: RSP g0-007-17 Safety Rod SCRAM with Distorted Axial Flux Shape

This test will verify safety rod worth when the neutron flux is peaked towards tha bottom of the reactor (Roof Top Ratio $(R T R)=0.90$ ). Safety analyses assume this is a worst case condition. With the flux peaked at the bottom of the reactor, the safety rods will not be fully effective until they are near the bottom of the reartor. This test will compare the observed relative change in flux with predictions taken trom safety analyses.

Predictions: Expected decrease in relative flux caused by a safety rod SCRAM is shown in Figure 108.

Acceptance Criteria: The observed relative flux as measured by neutron flux detectors will decrease greater and quicker than prediction shown in Figure 108.

References: Restart Test Identification Repert \#4, K-Reactor Power Ascension (U), WSAC-TR-90-29-004K, Outline \#17, November 7, 1990.

Wallace, J. M., AA3 Analyses for the Safaty Rod SCRAM Tests During K-14 Startup Testing Program (U), RRD-RTS-910071 February 8, 1991. 
WSRC-TR-91-42-043

Page 21 of 138

June 4, 1991

Section 17: RSP 90-007-18 Reactor Shutdown by Supplementary Safety System (SSS)

This test will confirm that one side of the SSS is capable of shutting down the reactor. The observed reactor response as determined by the assembly effluent temperature-versus-time on the Data Acquisition System will be compared to predictions. Observed responses on the following instruments will also be compared to predictions:

Internal Fission Counter Rod (2 neutron detectors and 1 gamma detector) located in sector without sparger injection.

Predictions: Expected decrease in relative flux and assembly delta T caused by SSS injection are shown in Figures 109 and 110 respectively.

Acceptance Criteria: The observed relative flux as measured by neutron flux detectors, and observed change in assembly deita T will decrease greater and quicker than predictions shown in Figures 109 and 110.

Measured injection line pressure and poison solution levels in storage tank versus time following system actuation satisty the parameter ranges shown in Table 7.

References: Restart Test Identification Repert \#4.K-Reactor Power Ascension (U). WSRC-TR-90-29-004K, Outline \#18, February 27, 1991.

Byrne, B. A. and Paik, I. K., Supplementary Safety System and Safety Rod Startup Test Acceptance Criteria, SAL-SAG-910306, WSRC-RP-91-584, June 1991. 
WSRC-TR-91-42-043

Page 22 of 138

June 4, 1991

TABLE 1

REACTIVITY HELD IN FISSION PRODUCTS DURING POWER ASCENSION

Power Ascension - 1 Week at $60 \%$ Power

Power Level Actual Power Reactivity held in Fission Products (AK)

(MW) Min Estimated Max

Eull Power-600MW

$\begin{array}{lclll}20 \% & 75 & 0.00000 & 0.00019 & 0.00038 \\ 40 \% & 120 & 0.00548 & 0.00648 & 0.00748 \\ 60 \% & 240 & 0.01013 & 0.01126 & 0.01239 \\ 90 \% & 360 & 0.01411 & 0.01568 & 0.01725 \\ 90 & 540 & 0.01747 & 0.01941 & 0.02135\end{array}$

Eull Power-700 MW

$\begin{array}{ll}20 \% & 75 \\ 40 \% & 140 \\ 60 \% & 280 \\ 90 \% & 420 \\ & 630\end{array}$

0.00000

0.00634

0.01124

0.01544

0.01886

0.00019

0.00038

$0.00734 \quad 0.00834$

$0.01249 \quad 0.0137 i$

$0.01716 \quad 0.01888$

$0.02095 \quad 0.02304$

Eull Power-800 MW

$\begin{array}{ll}20 \% & 75 \\ 40 \% & 16 \tilde{u} \\ 60 \% & 320 \\ 90 \% & 480 \\ & 720\end{array}$

0.00000

0.00716

0.01225

0.01663

0.02004

Eull Pewer-900 MNW

$\begin{array}{lc}20 \% & 75 \\ 40 \% & 180 \\ 60 \% & 360 \\ 90 \% & 540 \\ & 810\end{array}$

0.00000

0.00793

0.01317

0.01768

0.02108

$\begin{array}{ll}0.00019 & 0.00038 \\ 0.00816 & 0.00916 \\ 0.01361 & 0.01497 \\ 0.01848 & 0.02033 \\ 0.02227 & 0.02450\end{array}$

Eull Power-1000MW

$20 \%$

$40 \%$

$60 \%$

$90 \%$

Eull Power - Hoe MW

$20 \%$

$40 \%$

$60 \%$

$90 \%$

Eull Power-1200MW

$20 \% \quad 240$

$40 \%$

$60 \%$

$90 \%$

75
220

440

660

990

0.00000

0.00866

0.01401

0.01864

0.02200

0.00000

0.00932

0.01478

0.01949

0.02281

0.00019

0.00893

0.01463

0.01965

0.02342

0.00038

0.00993

0.01609

0.02162

0.02576

$0.00019 \quad 0.00038$

$0.00966 \quad 0.01066$

$0.01557 \quad 0.01713$

$0.02071 \quad 0.02278$

$0.02444 \quad 0.02688$

$0.00019 \quad 0.00038$

$0.01035 \quad 0.01139$

$0.01642 \quad 0.01806$

$0.02166 \quad 0.02383$

$\begin{array}{ll}0.02534 & 0.02787\end{array}$

0.00000

0.00991

0.01549

0.02028

0.02353

0.00019

0.01101

0.01721

0.02253

0.02614

0.00038

0.01211

0.01893

0.02478

0.02875 
WSRC-TR-91-42-043

Page 23 of 138

June 4, 1991

TABLE 2

REACTIVITY HELD IN FISSION PRODUCTS DURING POWER ASCENSION

Power Ascension - 3 Weeks at $60 \%$ Power

Puper Level Actual Power

(MW)

Reactivity held in Fission Products $(\Delta K)$ Min Estimated Max

Eulleawer-600 MOW

$\begin{array}{lclll}20 \% & 75 & 0.00000 & 0.00019 & 0.00038 \\ 40 \% & 120 & 0.00548 & 0.00648 & 0.00748 \\ 60 \% & 240 & 0.01013 & 0.01126 & 0.01239 \\ 90 \% & 360 & 0.01575 & 0.01750 & 0.01925 \\ 90 & 540 & 0.01895 & 0.02106 & 0.02317\end{array}$

Eull Power- 700 Mon'

$\begin{array}{lclll}20 \% & 75 & 0.00000 & 0.00019 & 0.00038 \\ 40 \% & 140 & 0.00634 & 0.00734 & 0.00834 \\ 60 \% & 280 & 0.01124 & 0.01249 & 0.01374 \\ 90 \% & 420 & 0.01723 & 0.01914 & 0.02105 \\ & 630 & 0.02043 & 0.02270 & 0.02497\end{array}$

EullPower-800Mat

$20 \%$

$75 \quad 0.00000$

0.00716

0.01225

0.01852

$60 \%$

320

480

$90 \%$

720

0.02170

0.00019

0.00816

0.01361

0.00038

0.02058

0.00916

0.01497

0.02264

0.02411

0.02652

Eull Power-200 AdH

$\begin{array}{ll}20 \% & 75 \\ 40 \% & 180 \\ 60 \% & 360 \\ 90 \% & 810\end{array}$

0.00000

0.00793

0.01317

0.01967

0.02278

0.00019

0.00893

0.00038

0.01463

0.02186

0.00993

0.01609

0.02531

0.02405

0.02784

Eullewar - $1000 \mathrm{nW}$

$20 \%$

$40 \%$

$60 \%$

$90 \%$

Eull Eower - $1100 \mathrm{MW}$

$20 \%$

$40 \%$

$60 \%$

$90 \%$

Eull Power - 1200 MW

$20 \%$

$40 \%$

$60 \%$

$90 \%$
0.00000

0.00866

0.01401

0.02069

0.02372

900
0.00000

0.00932

0.01478

0.02161

0.02454

0.00000

0.00991

0.01549

0.02243

0.02527

$\begin{array}{ll}0.00019 & 0.00038 \\ 0.00966 & 0.01066 \\ 0.01557 & 0.01713 \\ 0.02299 & 0.02529 \\ 0.02636 & 0.02900\end{array}$

0.00019

0.01035

0.01642

0.02401

0.02727

0.00038

0.01139

0.01806

0.02641

0.03000

0.00019

0.00038

0.01101

0.01211

0.01893

0.02492

0.02808 
WSRC-TR-91-42-043

Page 24 of 138

June 4, 1991

TABLE 3

REACTIVITY HELD IN TEMPERATURE AND FISSION PRODUCTS

Power Ascension - I Week at $60 \%$ Power

Power Level Actual Power $\Delta \mathrm{K}$ held in Temperature and Fission Products $(\mathbf{M W})$

Min Estimated

$\operatorname{Max}$

Eull Fower-600 MW

$\begin{array}{ll}20 \% & 75 \\ 40 \% & 120 \\ 60 \% & 240 \\ 90 \% & 360 \\ & 540\end{array}$

0.00009

0.00563

0.01043

0.014 .55

0.01813

0.00037

0.00677

0.01185

0.01656

0.02073

0.00065

$0.007+2$

$0.6: 3 ? 7$

0.01854

0.02333

Eull Power. $700 \mathrm{saw}$

$\begin{array}{ll}20 \% & 75 \\ 40 \% & 140 \\ 60 \% & 280 \\ 90 \% & 620 \\ & 630\end{array}$

0.00009

0.00651

0.00037

0.00768

0.01317

0.01596 .

0.01819

0.01963

0.02249

0.00065

0.00885

C.01476

0.02041

0.02 .535

Eull Power - $800 \mathrm{MW}$

$\begin{array}{ll}20 \% & 75 \\ 40 \% & 160 \\ 60 \% & 320 \\ 90 \% & 480 \\ & 720\end{array}$

0.00009

0.00736

0.00037

0.00855

0.01439

0.01264

0.01965

0.02093

0.02403

0.00065

0.00975

0.01614

0.02209

0.02714

Eull Power. $900 \mathrm{MaW}$

$\begin{array}{ll}20 \% & 75 \\ 40 \% & 180 \\ 60 \% & 360 \\ 90 \% & 540 \\ & 810\end{array}$

0.00009

0.00815

0.01361

0.01835

0.02207

0.00037

0.00937

0.01551

0.02097

0.02540

0.00065

0.01059

0.01741

0.02359

0.02873

Eull Power - 1000MaY

$20 \%$

75

200

$40 \%$

$60 \%$

$90 \%$

400

600

900

0.00009

0.00891

0.01450

0.01938

0.02310

0.00037

0.01015

0.01655

0.02218

0.02664

0.00065

0.01139

0.01859

0.02498

0.03018

Eulleower- U00 MOH

$20 \%$

75

0.00009

0.00959

0.01532

0.02030

$60 \%$

440

660

$90 \%$

990

0.02402

0.00037

0.01089

0.01750

0.02327

0.02776

0.00065

0.01220

0.01967

0.012624

0.03150

Eull Power-1200NON

$\begin{array}{ll}20 \% & 75 \\ 40 \% & 240 \\ 60 \% & 480 \\ 90 \% & 720 \\ 90 & 1080\end{array}$

0.00009

0.00037

0.01160

0.01838

0.01608

0.02116

0.02429

0.02485

0.02878

0.00065

0.01299

0.02069

0.02742

0.03271 
WSRC-TR-91-42-043

Page 25 of 138

June 4, 1991

TABLE 4

REACTIVITY HELD IN TEMPERATURE AND FISSION PRODUCTS

Power Ascension - 3 Weeks at $60 \%$ Power

Power Level Actual Power $\Delta \mathbf{K}$ held in Temperature and Fission Products (MW) Min Estimated Max

Eull Power - $600 \mathrm{M} W$

$\begin{array}{lllll}20 \% & 75 & 0.00009 & 0.00037 & 0.00065 \\ 40 \% & 120 & 0.00563 & 0.00677 & 0.00792 \\ 60 \% & 240 & 0.01043 & 0.01185 & 0.01327 \\ 90 \% & 360 & 0.01619 & 0.01838 & 0.02057 \\ & 540 & 0.01962 & 0.02238 & 0.02514\end{array}$

Eull Power- Z00NOW

$\begin{array}{lclll}20 \% & 75 & 0.00009 & 0.00037 & 0.00065 \\ 40 \% & 140 & 0.00651 & 0.00768 & 0.00885 \\ 60 \% & 280 & 0.01158 & 0.01317 & 0.01476 \\ 90 \% & 420 & 0.01774 & 0.02017 & 0.02259 \\ & 630 & 0.02120 & 0.02424 & 0.02728\end{array}$

Eull Power-800MW

$\begin{array}{ll}20 \% & 75 \\ 40 \% & 160 \\ 60 \% & 320 \\ 90 \% & 480 \\ & 720\end{array}$

0.00009

0.00736

0.01264

0.01911

0.02258

0.00037

0.00065

0.00855

0.00975

0.01439

0.01614

0.02175

0.02440

Eulleomer-goemu

$\begin{array}{lc}20 \% & 75 \\ 40 \% & 180 \\ 60 \% & 360 \\ 90 \% & 540 \\ & 810\end{array}$

0.00009

0.00815

$0.0136 \mathrm{i}$

0.02034

0.02377

0.02587

0.02916

EullPower-1000MON

$\begin{array}{ll}20 \% & 75 \\ 40 \% & 200 \\ 60 \% & 400 \\ 90 \% & 900\end{array}$

0.00009

0.00891

0.01450

0.02143

0.02483

0.00037

0.00937

0.00065

0.01551

0.01059

0.01741

0.02318

0.02602

0.02729

0.03081

Eull Pomer- Uee MTW

$\begin{array}{ll}20 \% & 75 \\ 40 \% & 220 \\ 60 \% & 640 \\ 90 \% & 990\end{array}$

$\begin{array}{ll}75 & 0.00009 \\ 220 & 0.00959\end{array}$

0.01532

0.02242

0.00037

0.00065

0.01015

0.01139

0.01655

0.01859

0.02446

0.02749

0.03229

$90 \%$

660

990

0.02576

0.00037

0.01089

0.00065

0.01750

0.01220

0.01967

0.02562

0.02883

0.02969

0.03362

Eulleower-1200 MOH

$20 \%$

0.00009

0.00037

0.00065

4096

0.01020

0.01160

0.01299

$60 \%$

480

001608

0.01838

0.02069

$90 \%$

1080

0.02331

0.02668

0.03005

0.02660

0.03072

0.03485 
WSRC-TR-91-42-043

Page 26 of 138

June 4, 1991

TABLE 5

Relative Radial Power Shape Limits

Double Partial Rods at 800 vu

\begin{tabular}{|c|c|c|c|c|c|}
\hline $\begin{array}{l}\text { Full Rod } \\
\text { Position }\end{array}$ & Limits & Gang 1 & Gang 2 & Gang 3 & Buckled Zone \\
\hline $2500 \mathrm{Vu}$ & $\begin{array}{l}\text { Lower } \\
\text { Upper }\end{array}$ & $\begin{array}{l}1.100 \\
0.900\end{array}$ & $\begin{array}{l}1.019 \\
0.833\end{array}$ & $\begin{array}{l}0.887 \\
0.591\end{array}$ & $\begin{array}{l}0.715 \\
0.477\end{array}$ \\
\hline $2400 \mathrm{vu}$ & $\begin{array}{l}\text { Lower } \\
\text { Upper }\end{array}$ & $\begin{array}{l}1.100 \\
0.900\end{array}$ & $\begin{array}{l}1.016 \\
0.832\end{array}$ & $\begin{array}{l}0.883 \\
0.589\end{array}$ & $\begin{array}{l}0.709 \\
0.473\end{array}$ \\
\hline $2300 \mathrm{vu}$ & $\begin{array}{l}\text { Lower } \\
\text { Upper }\end{array}$ & $\begin{array}{l}1.100 \\
0.900\end{array}$ & $\begin{array}{l}1.015 \\
0.831\end{array}$ & $\begin{array}{l}0.880 \\
0.586\end{array}$ & $\begin{array}{l}0.706 \\
0.470\end{array}$ \\
\hline $2200 \mathrm{vu}$ & $\begin{array}{l}\text { Lower } \\
\text { Upper }\end{array}$ & $\begin{array}{l}1.100 \\
0.900\end{array}$ & $\begin{array}{l}1.011 \\
0.827\end{array}$ & $\begin{array}{l}0.872 \\
0.582\end{array}$ & $\begin{array}{l}0.694 \\
0.462\end{array}$ \\
\hline $2100 \mathrm{vu}$ & $\begin{array}{l}\text { Lower } \\
\text { Upper }\end{array}$ & $\begin{array}{l}1.100 \\
0.900\end{array}$ & $\begin{array}{l}1.007 \\
0.824\end{array}$ & $\begin{array}{l}0.864 \\
0.576\end{array}$ & $\begin{array}{l}0.680 \\
0.454\end{array}$ \\
\hline $2000 \mathrm{vu}$ & $\begin{array}{l}\text { Lower } \\
\text { Upper }\end{array}$ & $\begin{array}{l}1.100 \\
0.900\end{array}$ & $\begin{array}{l}1.007 \\
0.824\end{array}$ & $\begin{array}{l}0.863 \\
0.575\end{array}$ & $\begin{array}{l}0.679 \\
0.453\end{array}$ \\
\hline $1900 \mathrm{vu}$ & $\begin{array}{l}\text { Lower } \\
\text { Upper }\end{array}$ & $\begin{array}{l}1.100 \\
0.900\end{array}$ & $\begin{array}{l}1.007 \\
0.824\end{array}$ & $\begin{array}{l}0.863 \\
0.575\end{array}$ & $\begin{array}{l}0.679 \\
0.453\end{array}$ \\
\hline $1800 \mathrm{vu}$ & $\begin{array}{l}\text { Lower } \\
\text { Upper }\end{array}$ & $\begin{array}{l}1.100 \\
0.900\end{array}$ & $\begin{array}{l}1.003 \\
0.821\end{array}$ & $\begin{array}{l}0.858 \\
0.572\end{array}$ & $\begin{array}{l}0.671 \\
0.447\end{array}$ \\
\hline $1700 \mathrm{vu}$ & $\begin{array}{l}\text { Lower } \\
\text { Upper }\end{array}$ & $\begin{array}{l}1.100 \\
0.900\end{array}$ & $\begin{array}{l}1.000 \\
0.818\end{array}$ & $\begin{array}{l}0.851 \\
0.567\end{array}$ & $\begin{array}{l}0.660 \\
0.440\end{array}$ \\
\hline $1600 \mathrm{vu}$ & $\begin{array}{l}\text { Lower } \\
\text { Upper }\end{array}$ & $\begin{array}{l}1.100 \\
0.900\end{array}$ & $\begin{array}{l}0.998 \\
0.816\end{array}$ & $\begin{array}{l}0.847 \\
0.565\end{array}$ & $\begin{array}{l}0.653 \\
0.435\end{array}$ \\
\hline $1500 \mathrm{vu}$ & $\begin{array}{l}\text { Lower } \\
\text { Upper }\end{array}$ & $\begin{array}{l}1.100 \\
0.900\end{array}$ & $\begin{array}{l}0.997 \\
0.815\end{array}$ & $\begin{array}{l}0.845 \\
0.563\end{array}$ & $\begin{array}{l}0.649 \\
0.433\end{array}$ \\
\hline $1400 \mathrm{vu}$ & $\begin{array}{l}\text { Lower } \\
\text { Upper }\end{array}$ & $\begin{array}{l}1.100 \\
0.900\end{array}$ & $\begin{array}{l}0.996 \\
0.815\end{array}$ & $\begin{array}{l}0.842 \\
0.561\end{array}$ & $\begin{array}{l}0.647 \\
0.431\end{array}$ \\
\hline $1300 \mathrm{vu}$ & $\begin{array}{l}\text { Lower } \\
\text { Upper }\end{array}$ & $\begin{array}{l}1.100 \\
0.900\end{array}$ & $\begin{array}{l}0.994 \\
0.814\end{array}$ & $\begin{array}{l}0.840 \\
0.560\end{array}$ & $\begin{array}{l}0.643 \\
0.429\end{array}$ \\
\hline
\end{tabular}


WSRC-TR-91-42-043

Page 27 of 138

June 4, 1991

TABLE 6

Limits on Axial Power Shape

Double Partial Rods at $800 \mathrm{vu}$

\begin{tabular}{|c|c|c|c|c|c|c|c|c|}
\hline $\begin{array}{l}\text { Full Rod } \\
\text { Position }\end{array}$ & Limit & $\begin{array}{c}\text { Sensor } \\
1 \\
\text { (top) }\end{array}$ & $\begin{array}{c}\text { Sensor } \\
2\end{array}$ & $\begin{array}{c}\text { Sensor } \\
3\end{array}$ & $\begin{array}{c}\text { Sensor } \\
4\end{array}$ & $\begin{array}{c}\text { Sensor } \\
5\end{array}$ & $\begin{array}{c}\text { Sensor } \\
6\end{array}$ & $\begin{array}{c}\text { Sensor } \\
7 \\
\text { bottom) }\end{array}$ \\
\hline $2500 \mathrm{vu}$ & $\begin{array}{l}\text { Lower } \\
\text { Upper }\end{array}$ & $\begin{array}{l}0.119 \\
0.819\end{array}$ & $\begin{array}{l}0.368 \\
1.068\end{array}$ & $\begin{array}{l}0.464 \\
1.164\end{array}$ & $\begin{array}{l}0.830 \\
1.530\end{array}$ & $\begin{array}{l}1.065 \\
1.765\end{array}$ & $\begin{array}{l}1.032 \\
1.732\end{array}$ & $\begin{array}{l}0.673 \\
1.373\end{array}$ \\
\hline $2400 \mathrm{vu}$ & $\begin{array}{l}\text { Lower } \\
\text { Upper }\end{array}$ & $\begin{array}{l}0.141 \\
0.841\end{array}$ & $\begin{array}{l}0.415 \\
1.115\end{array}$ & $\begin{array}{l}0.533 \\
1.233\end{array}$ & $\begin{array}{l}0.917 \\
1.617\end{array}$ & $\begin{array}{l}1.005 \\
1.705\end{array}$ & $\begin{array}{l}0.945 \\
1.645\end{array}$ & $\begin{array}{l}0.593 \\
1.293\end{array}$ \\
\hline $2300 \mathrm{vu}$ & $\begin{array}{l}\text { Lower } \\
\text { Upper }\end{array}$ & $\begin{array}{l}0.205 \\
0.905\end{array}$ & $\begin{array}{l}0.527 \\
1.227\end{array}$ & $\begin{array}{l}0.675 \\
1.375\end{array}$ & $\begin{array}{l}0.918 \\
1.618\end{array}$ & $\begin{array}{l}0.903 \\
1.603\end{array}$ & $\begin{array}{l}0.827 \\
1.527\end{array}$ & $\begin{array}{l}0.495 \\
1.195\end{array}$ \\
\hline $2200 \mathrm{vu}$ & $\begin{array}{l}\text { Lower } \\
\text { Upper }\end{array}$ & $\begin{array}{l}0.412 \\
1.112\end{array}$ & $\begin{array}{l}0.822 \\
1.522\end{array}$ & $\begin{array}{l}0.844 \\
1.544\end{array}$ & $\begin{array}{l}0.839 \\
1.539\end{array}$ & $\begin{array}{l}0.698 \\
1.398\end{array}$ & $\begin{array}{l}0.610 \\
1.310\end{array}$ & $\begin{array}{l}0.325 \\
1.025\end{array}$ \\
\hline $100 \mathrm{vu}$ & $\begin{array}{l}\text { Lower } \\
\text { Upper }\end{array}$ & $\begin{array}{l}0.668 \\
1.368\end{array}$ & $\begin{array}{l}0.989 \\
1.689\end{array}$ & $\begin{array}{l}0.922 \\
1.622\end{array}$ & $\begin{array}{l}0.758 \\
1.458\end{array}$ & $\begin{array}{l}0.549 \\
1.249\end{array}$ & $\begin{array}{l}0.456 \\
1.156\end{array}$ & $\begin{array}{l}0.207 \\
0.907\end{array}$ \\
\hline $2000 \mathrm{vu}$ & $\begin{array}{l}\text { Lower } \\
\text { Upper }\end{array}$ & $\begin{array}{l}0.693 \\
1.393\end{array}$ & $\begin{array}{l}1.004 \\
1.704\end{array}$ & $\begin{array}{l}0.929 \\
1.629\end{array}$ & $\begin{array}{l}0.750 \\
1.450\end{array}$ & $\begin{array}{l}0.535 \\
1.235\end{array}$ & $\begin{array}{l}0.442 \\
1.142\end{array}$ & $\begin{array}{l}0.197 \\
0.897\end{array}$ \\
\hline $1900 \mathrm{vu}$ & $\begin{array}{l}\text { Lower } \\
\text { Upper }\end{array}$ & $\begin{array}{l}0.689 \\
1.389\end{array}$ & $\begin{array}{l}0.999 \\
1.699\end{array}$ & $\begin{array}{l}0.924 \\
1.624\end{array}$ & $\begin{array}{l}0.749 \\
1.449\end{array}$ & $\begin{array}{l}0.538 \\
1.238\end{array}$ & & $\begin{array}{l}0.204 \\
0.904\end{array}$ \\
\hline $1800 \mathrm{Vu}$ & $\begin{array}{l}\text { Lower } \\
\text { Upper }\end{array}$ & $\begin{array}{l}0.566 \\
1.266\end{array}$ & $\begin{array}{l}0.852 \\
1.552\end{array}$ & $\begin{array}{l}0.800 \\
1.500\end{array}$ & $\begin{array}{l}0.709 \\
1.400\end{array}$ & $\begin{array}{l}0.622 \\
1.322\end{array}$ & & $\begin{array}{l}0.409 \\
1.109\end{array}$ \\
\hline $1700 \mathrm{Vu}$ & $\begin{array}{l}\text { Lower } \\
\text { Upper }\end{array}$ & $\begin{array}{l}0.378 \\
1.078\end{array}$ & $\begin{array}{l}0.625 \\
1.325\end{array}$ & $\begin{array}{l}0.609 \\
1.309\end{array}$ & $\begin{array}{l}0.653 \\
1.353\end{array}$ & $\begin{array}{l}0.782 \\
1.482\end{array}$ & $\begin{array}{l}0.857 \\
1.557\end{array}$ & $\begin{array}{l}0.646 \\
1.346\end{array}$ \\
\hline $1600 \mathrm{vu}$ & $\begin{array}{l}\text { Lower } \\
\text { Upper }\end{array}$ & $\begin{array}{l}0.290 \\
0.990\end{array}$ & $\begin{array}{l}0.522 \\
1.222\end{array}$ & $\begin{array}{l}0.527 \\
1.227\end{array}$ & $\begin{array}{l}0.654 \\
1.354\end{array}$ & & $\begin{array}{l}0.950 \\
1.650\end{array}$ & $\begin{array}{l}0.705 \\
1.405\end{array}$ \\
\hline $1500 \mathrm{Vu}$ & $\begin{array}{l}\text { Lower } \\
\text { Upper }\end{array}$ & $\begin{array}{l}0.262 \\
0.962\end{array}$ & $\begin{array}{l}0.496 \\
1.196\end{array}$ & $\begin{array}{l}0.516 \\
1.216\end{array}$ & $\begin{array}{l}0.720 \\
1.420\end{array}$ & $\begin{array}{l}0.923 \\
1.623\end{array}$ & $\begin{array}{l}0.947 \\
1.647\end{array}$ & $\begin{array}{l}0.687 \\
1.387\end{array}$ \\
\hline $1400 \mathrm{ve}$ & $\begin{array}{l}\text { Lower } \\
\text { Upper }\end{array}$ & $\begin{array}{l}0.280 \\
0.980\end{array}$ & $\begin{array}{l}0.531 \\
1.231\end{array}$ & $\begin{array}{l}0.566 \\
1.266\end{array}$ & $\begin{array}{l}0.781 \\
1.481\end{array}$ & $\begin{array}{l}0.882 \\
1.582\end{array}$ & $\begin{array}{l}0.885 \\
1.585\end{array}$ & $\begin{array}{l}0.625 \\
1.325\end{array}$ \\
\hline $300 \mathrm{~V}$ & $\begin{array}{l}\text { Lower } \\
\text { Upper }\end{array}$ & $\begin{array}{l}0.341 \\
1.041\end{array}$ & $\begin{array}{l}0.628 \\
1.328\end{array}$ & $\begin{array}{l}0.679 \\
1.379\end{array}$ & $\begin{array}{l}0.783 \\
1.483\end{array}$ & $\begin{array}{l}0.799 \\
1.499\end{array}$ & $\begin{array}{l}0.784 \\
1.484\end{array}$ & $\begin{array}{l}0.53 \\
1.23\end{array}$ \\
\hline
\end{tabular}


WSRC-TR-91-42-043

Page 28 of 138

June 4, 1991

TABLE 7

\section{SSS INJECTION TIMING AND FLOW CHARACTERISTICS}

\section{PARAMETERS TO BE MEASURED \\ RESPONSE TIMES}

\section{Spargor Injection}

Time delay from explosive valve circult switch contact to dbughnut flange indication o pojson solution injetion (lates of 3 lines)

\section{Pump Suction Injection}

Time delay from explosivg valye swtch contact to rupture disk indication of onser of in ection into process water system (latest of 3 injection peaks)

\section{WNECTIONFLOW CURVES}

\section{Sparger Injection}

Cymulative volume of poison solution, as indcated by decreasing lovel in storado tank

\section{PARAMETER YALUES, RANGES TO BE OBTAINED}

$$
\leq \quad 0.37 \text { seconds }
$$

Ensures polson solution effect on reactivity within 0.7 secong s and poison solution delvery to moderator space within 1.0 secbnd, as specifled in SAA Chapter 15 accident analyef

\section{$5 \quad 3.3$ seconds}

Ensures polson solution delvery into PWS within 4.0 seconds assumed in SAR Chapter 15 accident analysis

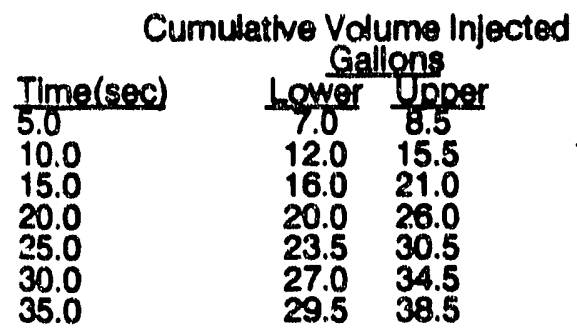

Cumulathe Volume Injected

Cumulathe volume of polson solution, as indicated by decreasing level in storage tank

\begin{tabular}{lcc} 
Time(sec) & \multicolumn{2}{c}{ Gallons } \\
Lower & Doger \\
5.0 & 4.0 & 7.0 \\
10.0 & 7.0 & 13.0 \\
15.0 & 10.0 & 17.0 \\
20.0 & 13.0 & 21.0 \\
25.0 & 15.0 & 25.0 \\
30.0 & 17.0 & 28.0 \\
35.0 & 19.0 & 32.0 \\
40.0 & 21.0 & 35.0 \\
45.0 & 22.0 & 38.0 \\
50.0 & 24.0 & 41.0 \\
55.0 & 26.0 & 43.0
\end{tabular}

$\geq 35.0$ seconds

$\geq 70.0$ seconds
Pump Suetton Injection

Time between rupture disk Indication (latest of 3 injection line pressure peaks) and end of in ection (earliest of injection line pressure indications of loss of fiow)

\section{Sparger Injection}

Indlcated by time difference between latest of injection line pressure peaks and earlest of Injection line indications of loss of flow past doughnut fiange 
WSRC-TR-91-42-043

Page 29 of 138

Jurie 4, 1991

FIGURE 1

\section{K-effective VS FULL ROD POSITION DOUBLE PARTIAL RODS AT $800 \mathrm{VU}$}

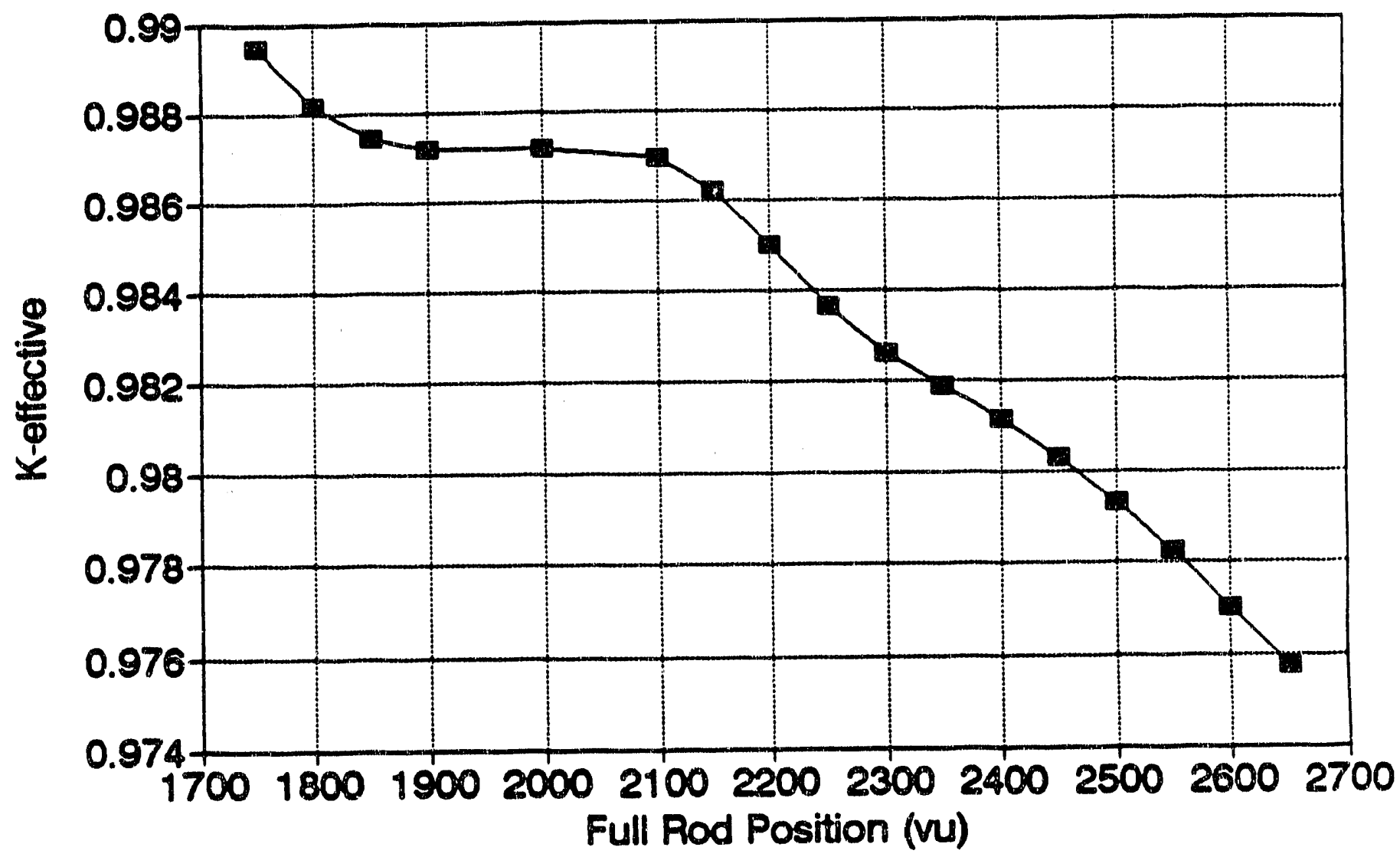


WSRC-TR-91-42-043

Page 30 of 138

June 4, 1991

FIGURE 2

\section{K-effective VS FULL ROD POSITON WEAK PARTIAL RODS AT $800 \mathrm{VU}$}

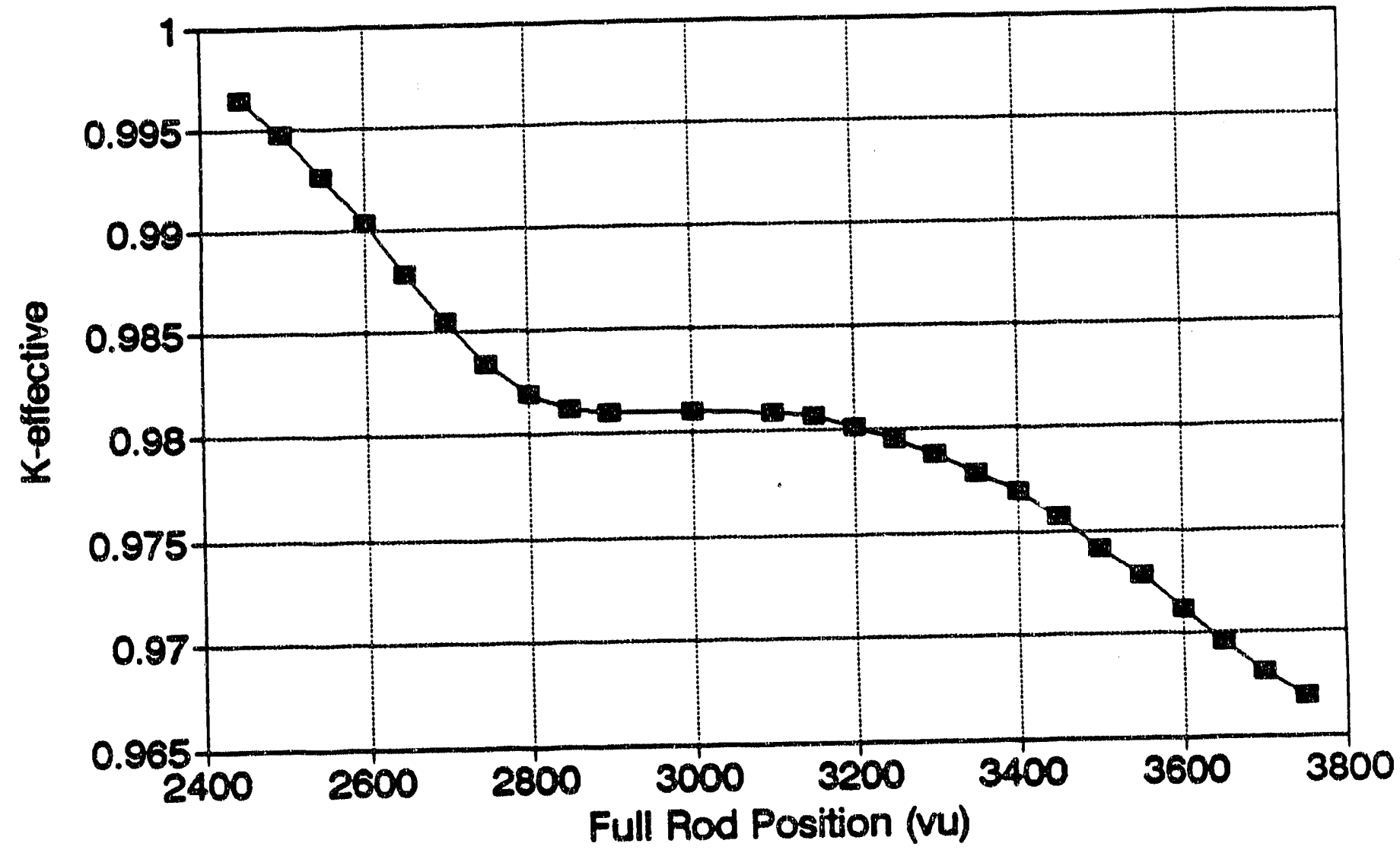


WSRC-TR-91-42-043

Page 31 of 138

June 4, 1991

FIGURE 3

\section{K-effective'VS FULL ROD POSITION DOUBLE PARTIAL RODS AT $700 \mathrm{VU}$}

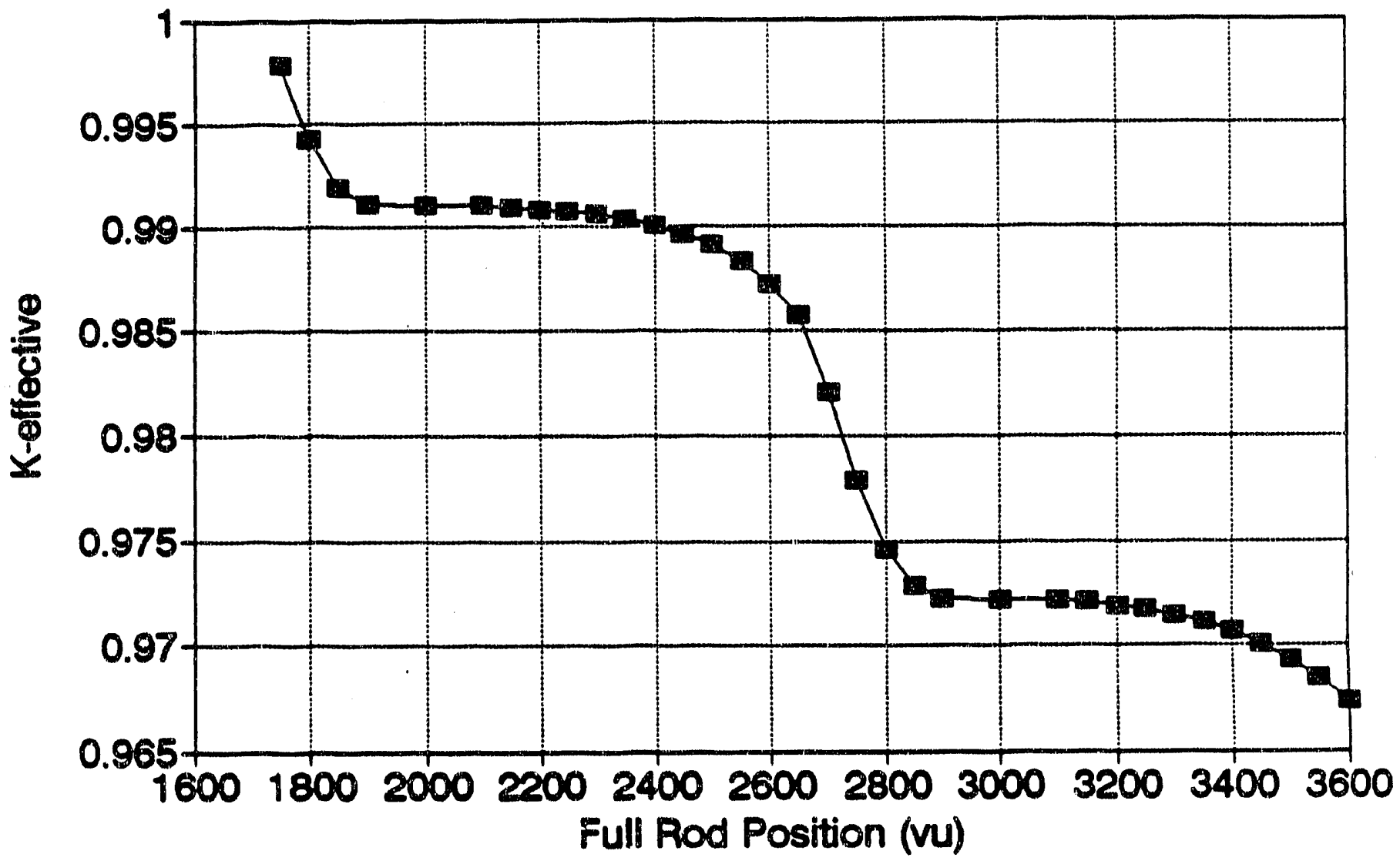


WSRC-TR- $91-42-043$

Page 32 of 138

June 4, 1991

FIGURE 4

\section{K-effective VS FULL ROD POSITION WEAK PARTIAL RODS AT $700 \mathrm{VU}$}

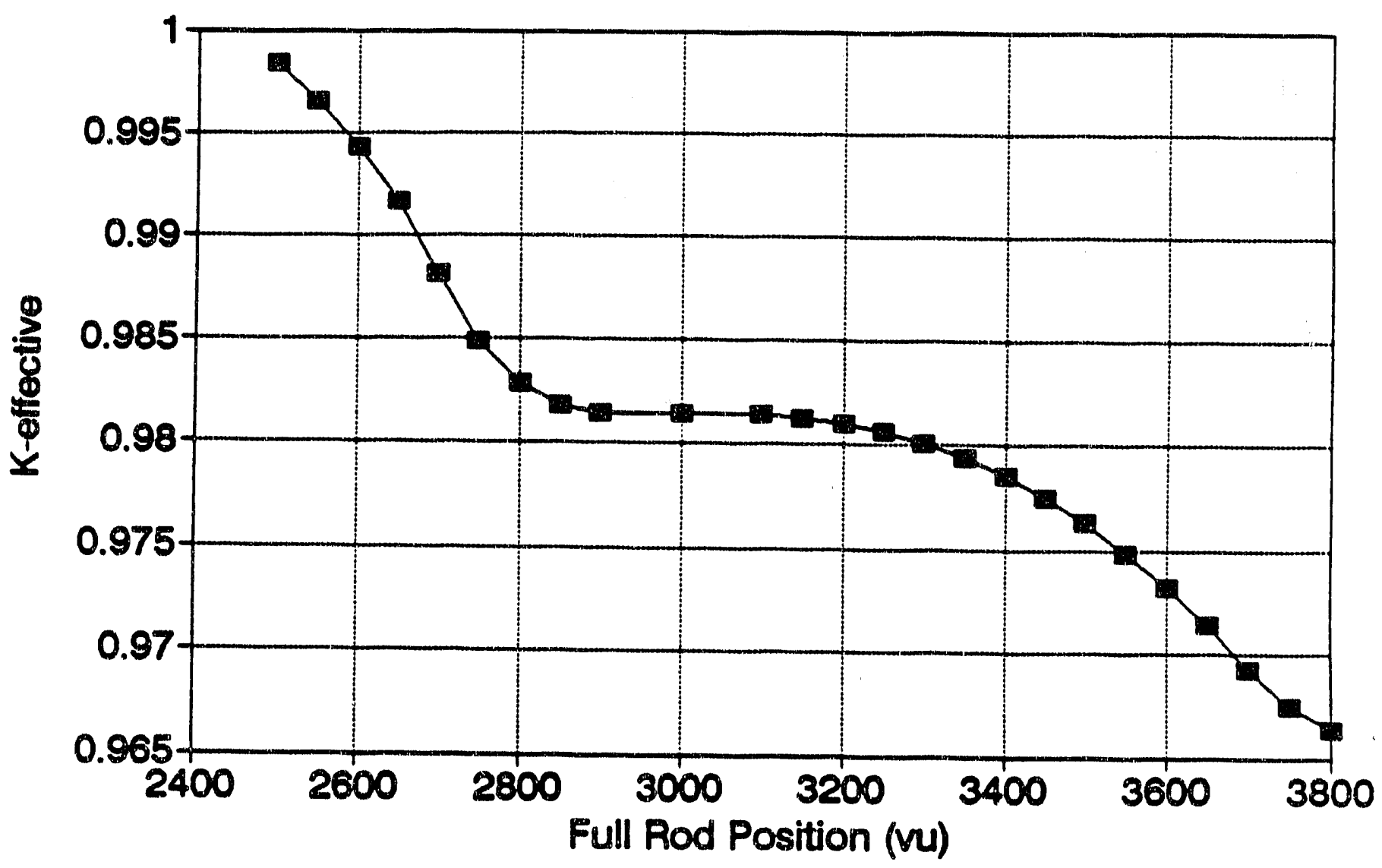


WSRC-TR-91-42-043

Page 33 of 138

June 4, 1991

FIGURE 5

\section{K-effective VS FULL ROD POSITION DOUBLE PARTIAL RODS AT $950 \mathrm{VU}$}

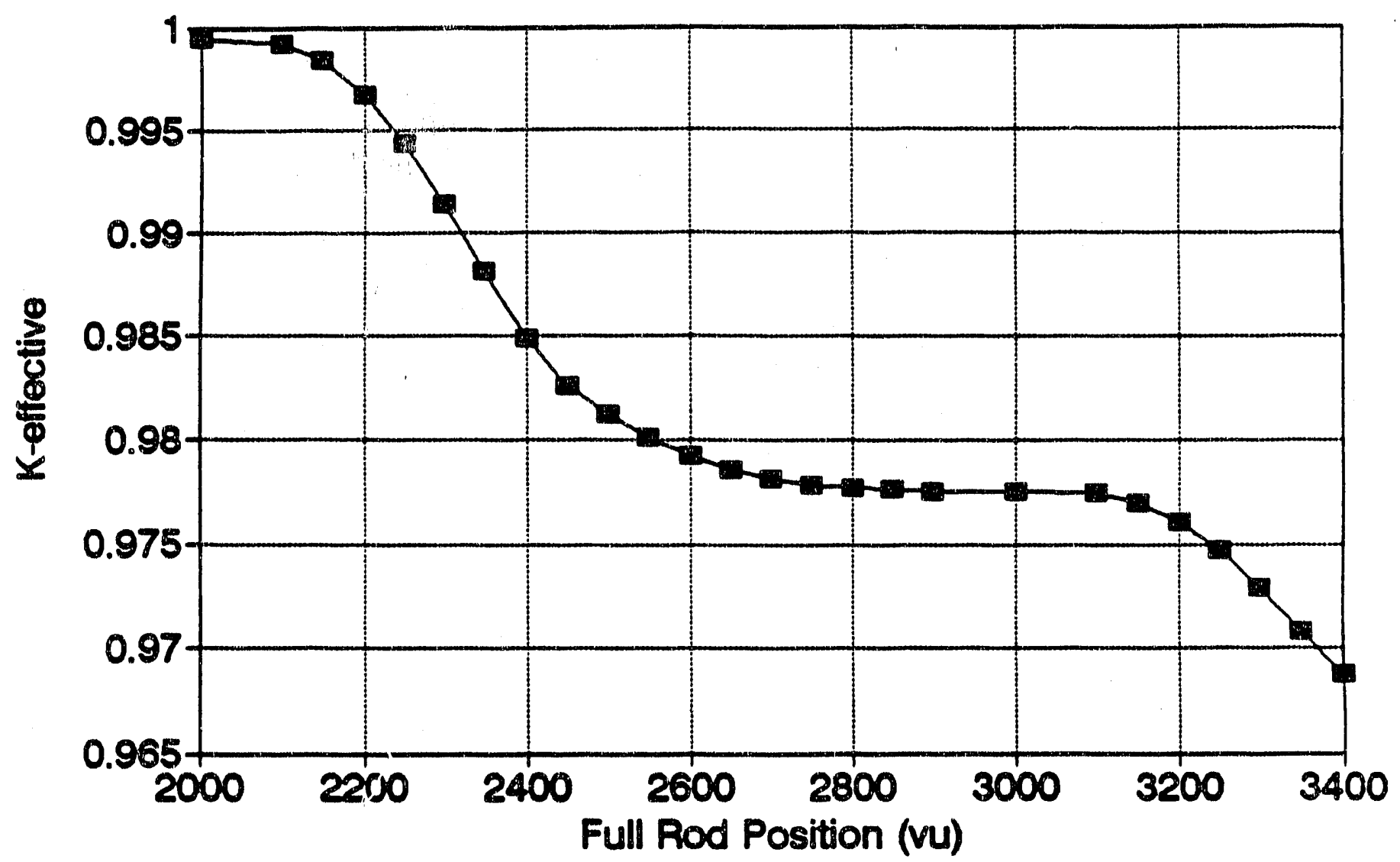


WSRC-TR-91-42-043

Page 34 of 138

June 4, 1991

FIGURE 6

K-effective VS FULL ROD POSITION
WEAK PARTIAL RODS AT 950 VU

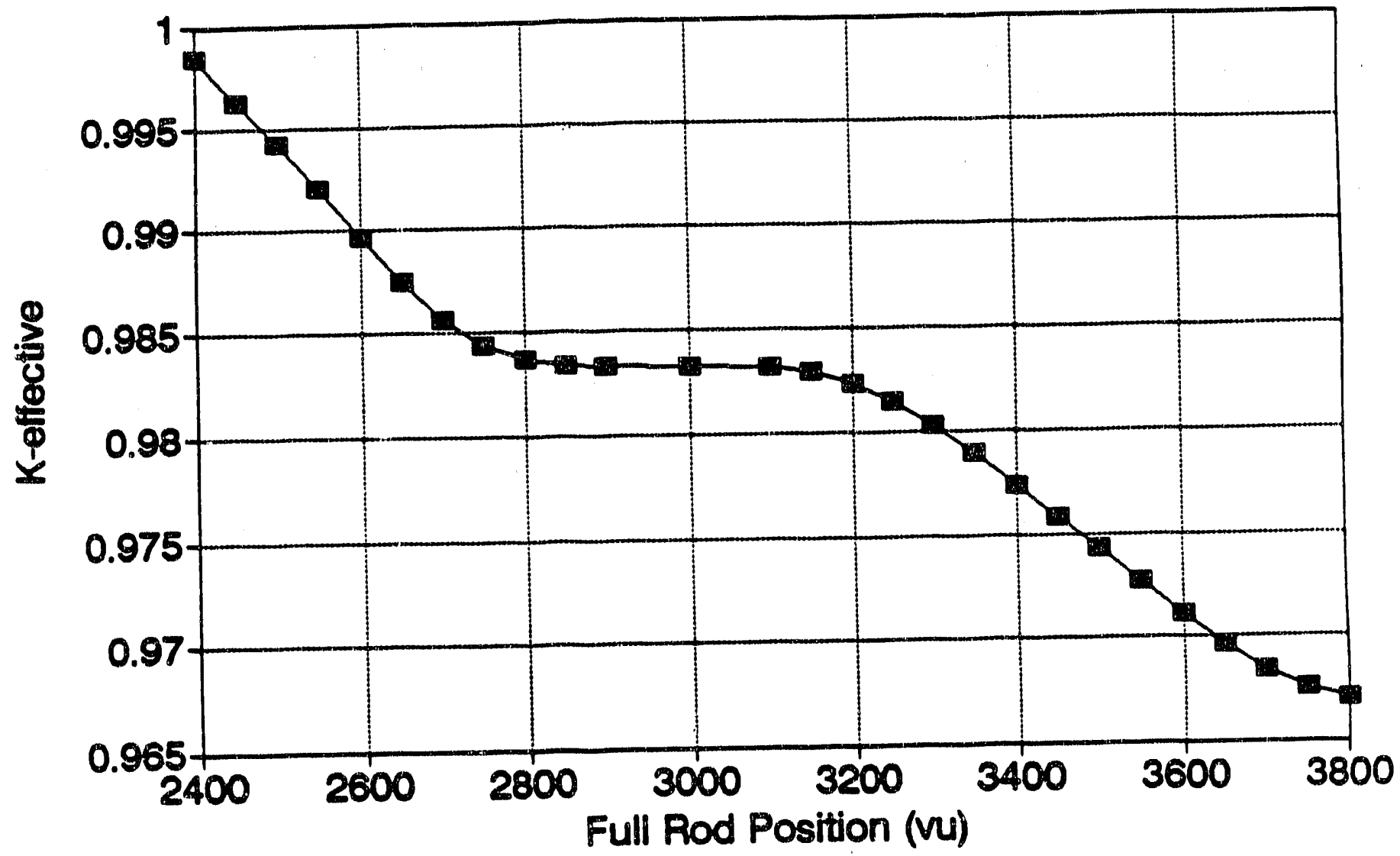


WSRC-TR-91-42-043

Page 35 of 138

June 4, 1991

FIGURE 7

\section{Full Control Rod Withdrawal - 50 vu Double Partial Control Rods at $800 \mathrm{vu}$}

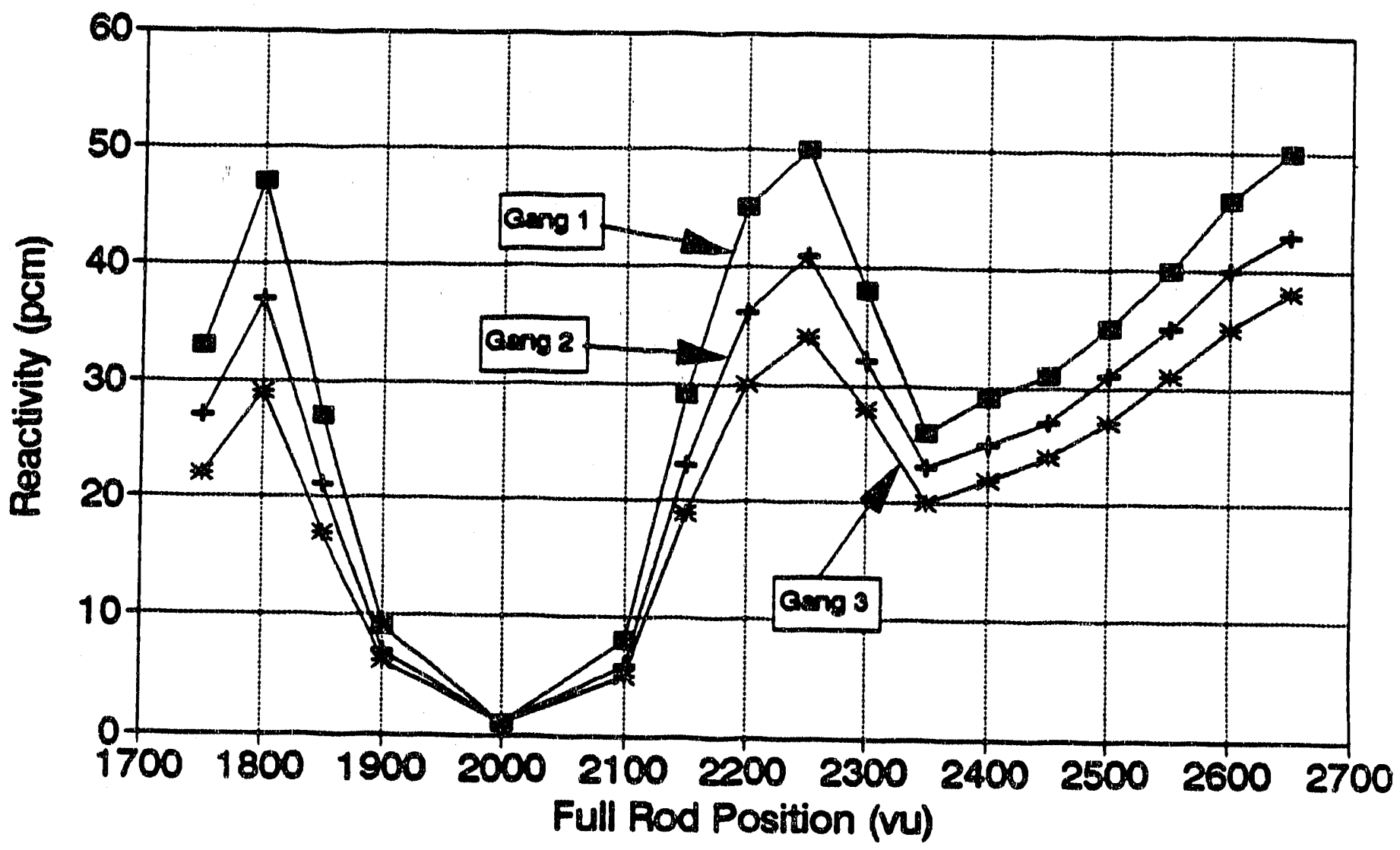


WSRC-TR-91-42-043

Page 36 of 138

June 4, 1991

FIGURE 8

\section{Full Control Rod Withdrawal - 50 vu Weak Partial Control Rods at $800 \mathrm{vu}$}

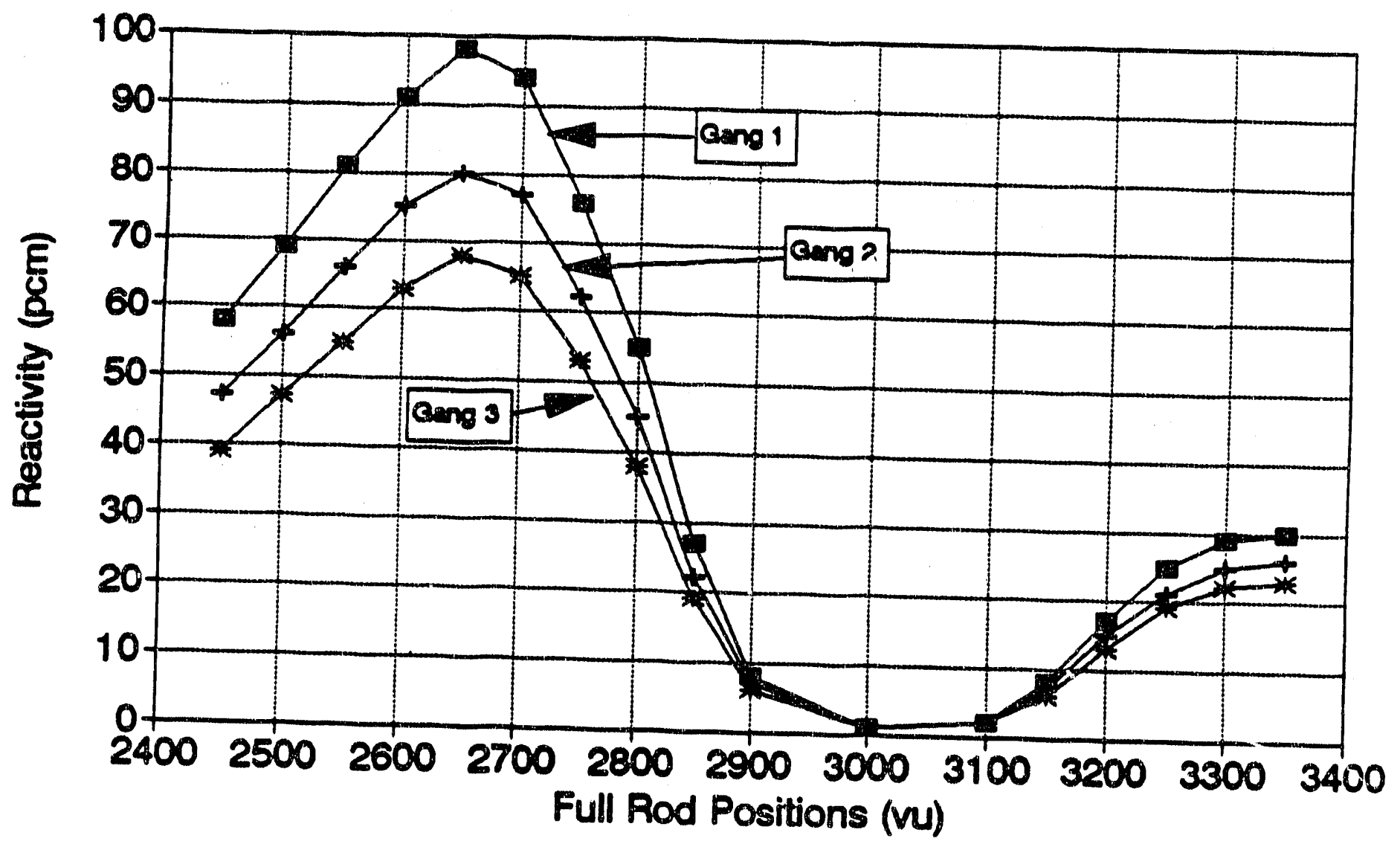


WSRCTR-91-42-043

Pege 37 of 138

June 4, 1991

FIGURE 9

\section{Full Control Rod Withdrawal - 50 vu Double Partial Rods at $700 \mathrm{vu}$}

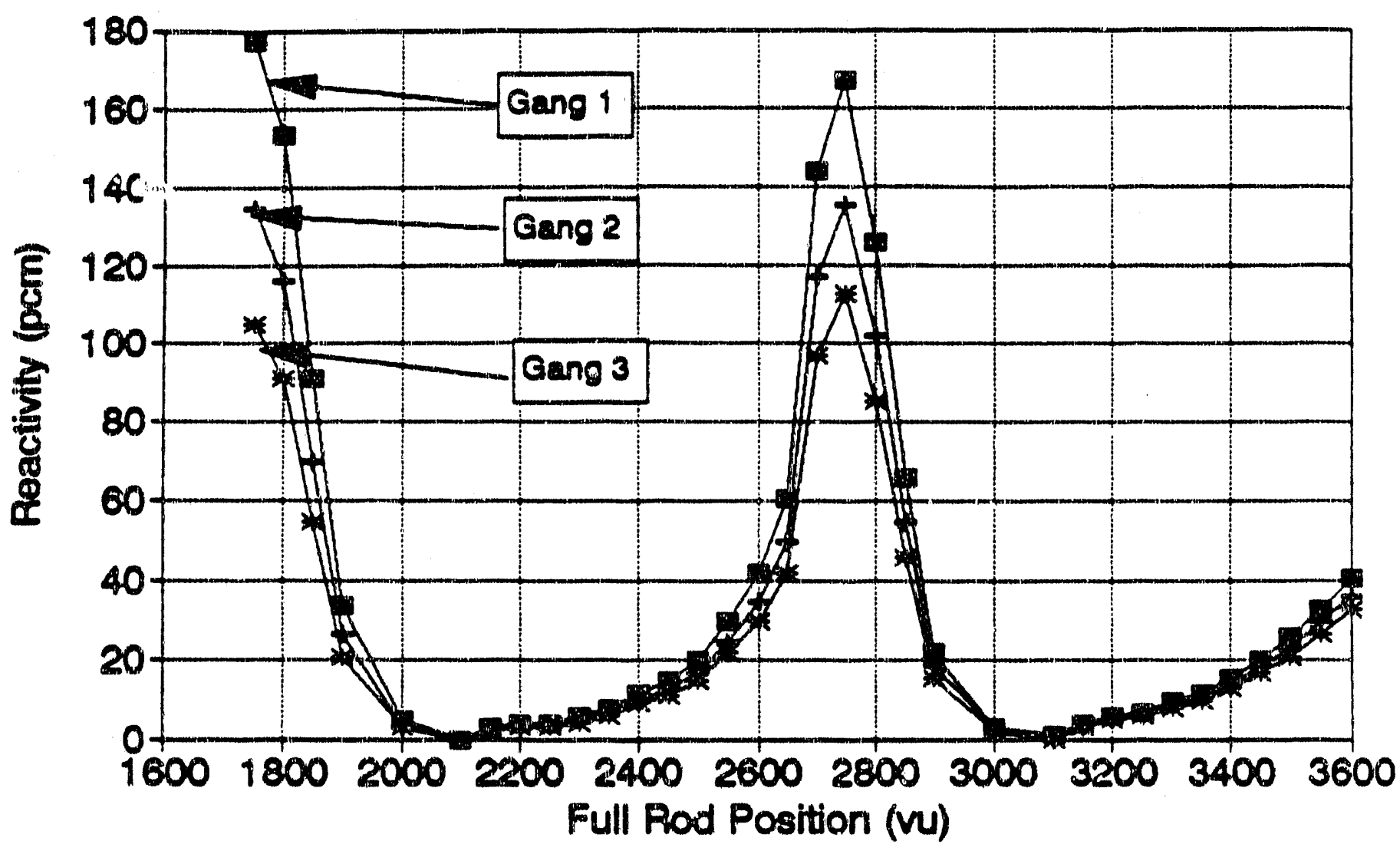


WSRC-TR-91-42-043

Page 38 of 138

June 4, 1991

FIGURE 10

\section{Full Control Rod Withdrawal - 50 vu Weak Partial Control Rods at $700 \mathrm{vu}$}

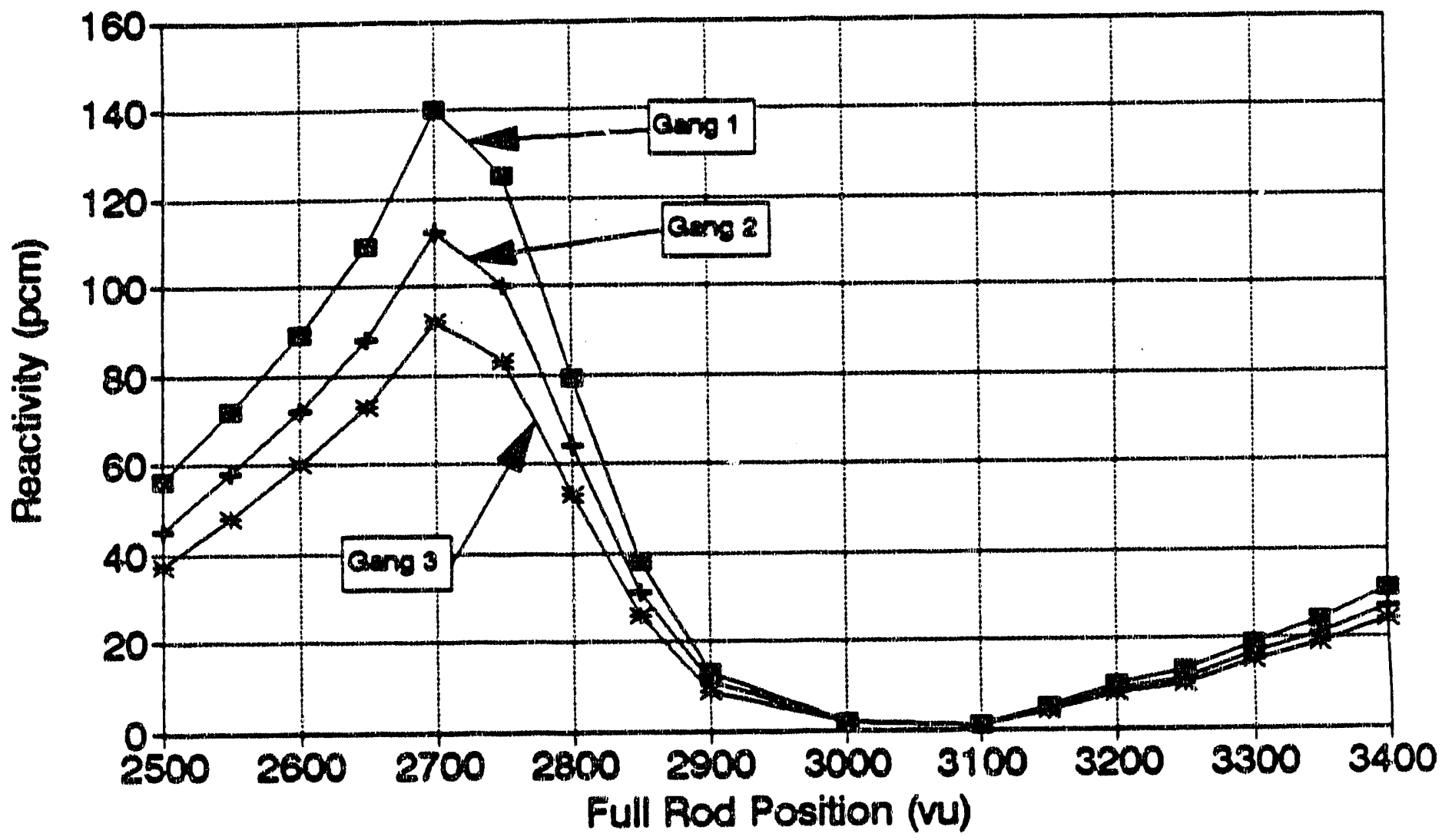


WSRC-TR-91-42-043

Page 39 of 138

June 4, 1991

FIGURE 11

\section{Full Control Rod Withdrawal - 50 vu Double Partial Control Rods at $950 \mathrm{vu}$}

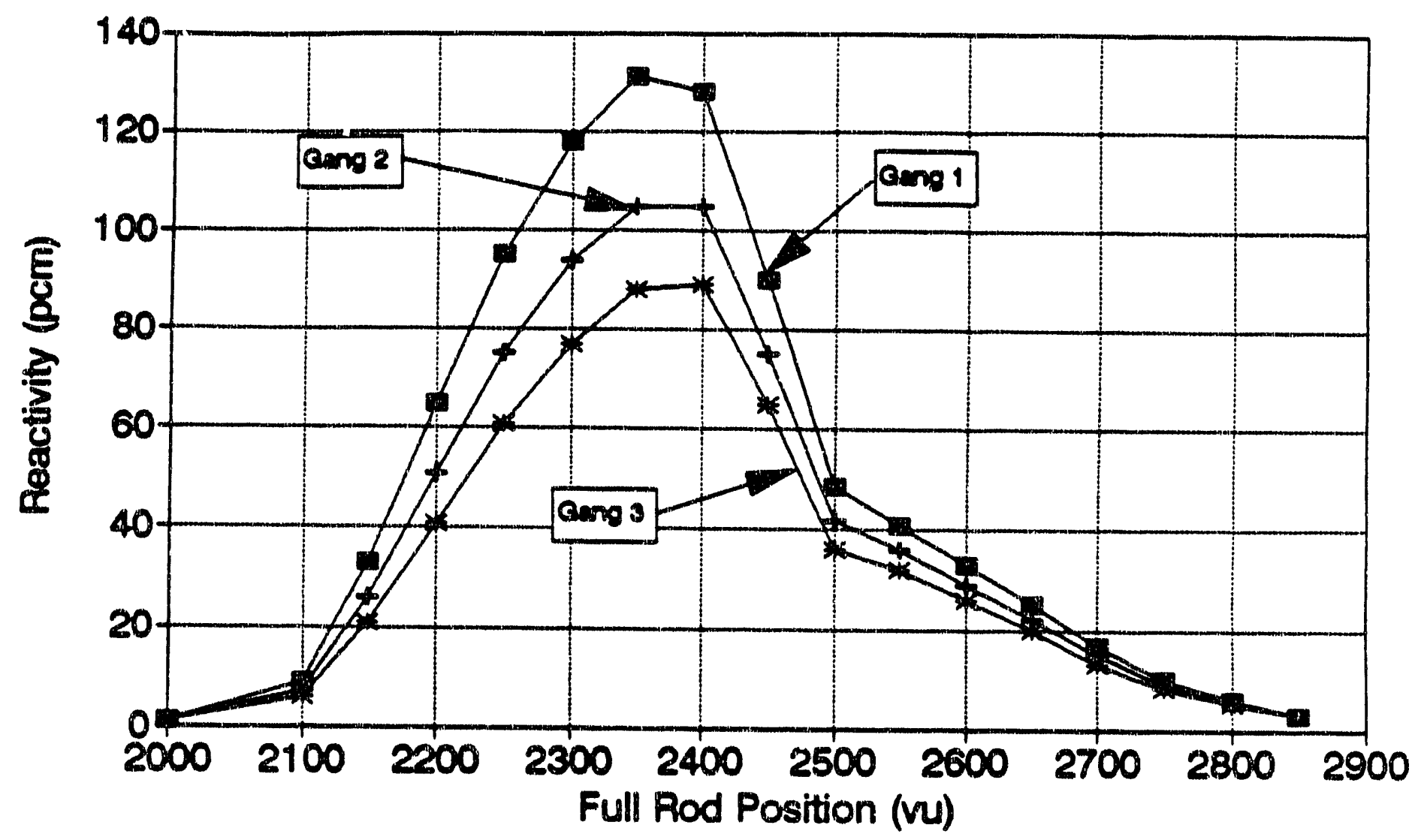


WSRC-TR-91-42-043

Page 40 of 138

June 4, 1991

FIGURE 12

\section{Full Control Rod Withdrawal - 50 vu Weak Partial Control Rods at 950 vu}

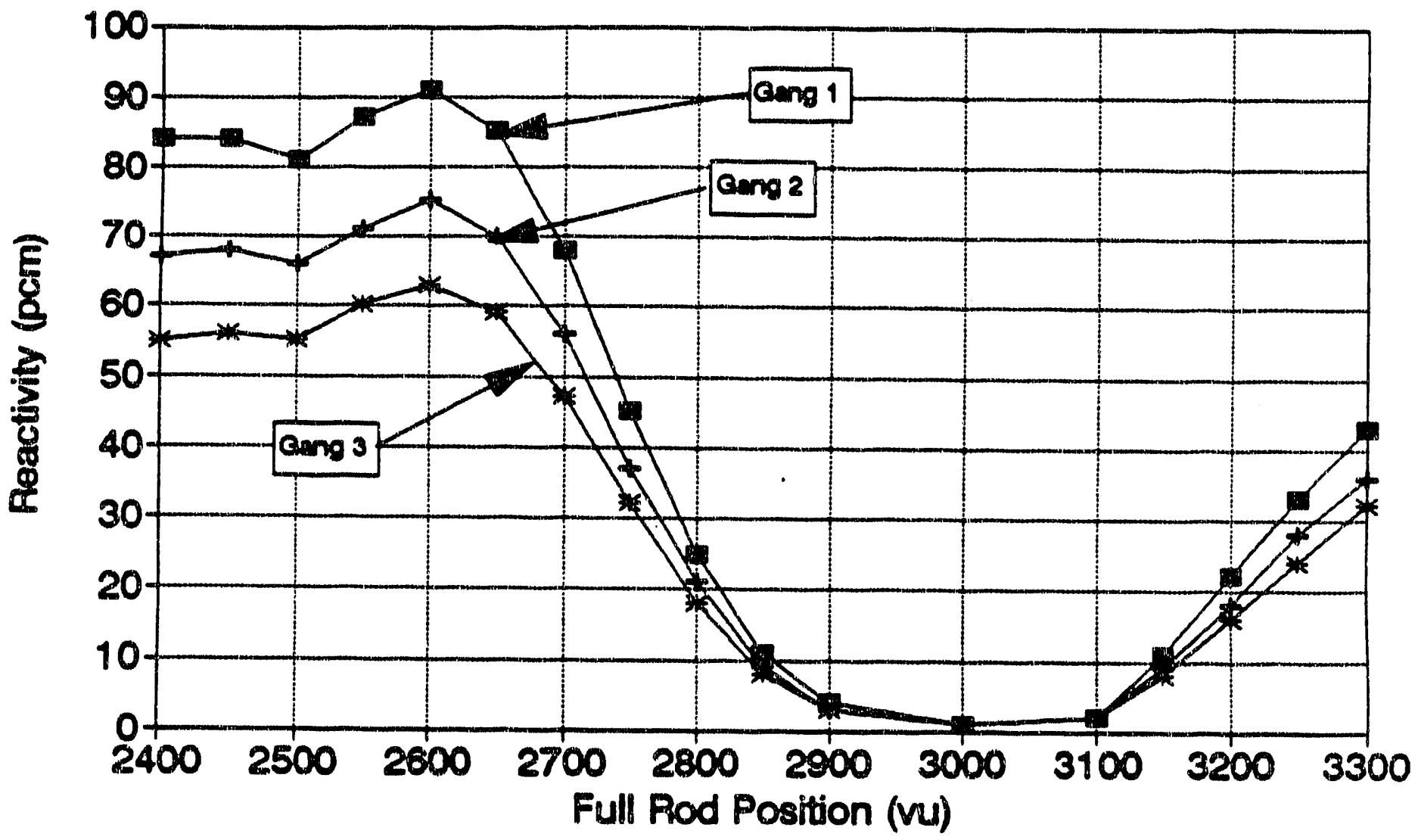


WSRC-TR-91-42-043

Page 41 of 138

June 4, 1991

FIGURE 13

Full Rod Withdrawal - 10 PCM Reactivity Double Partial Rods at $800 \mathrm{vu}$

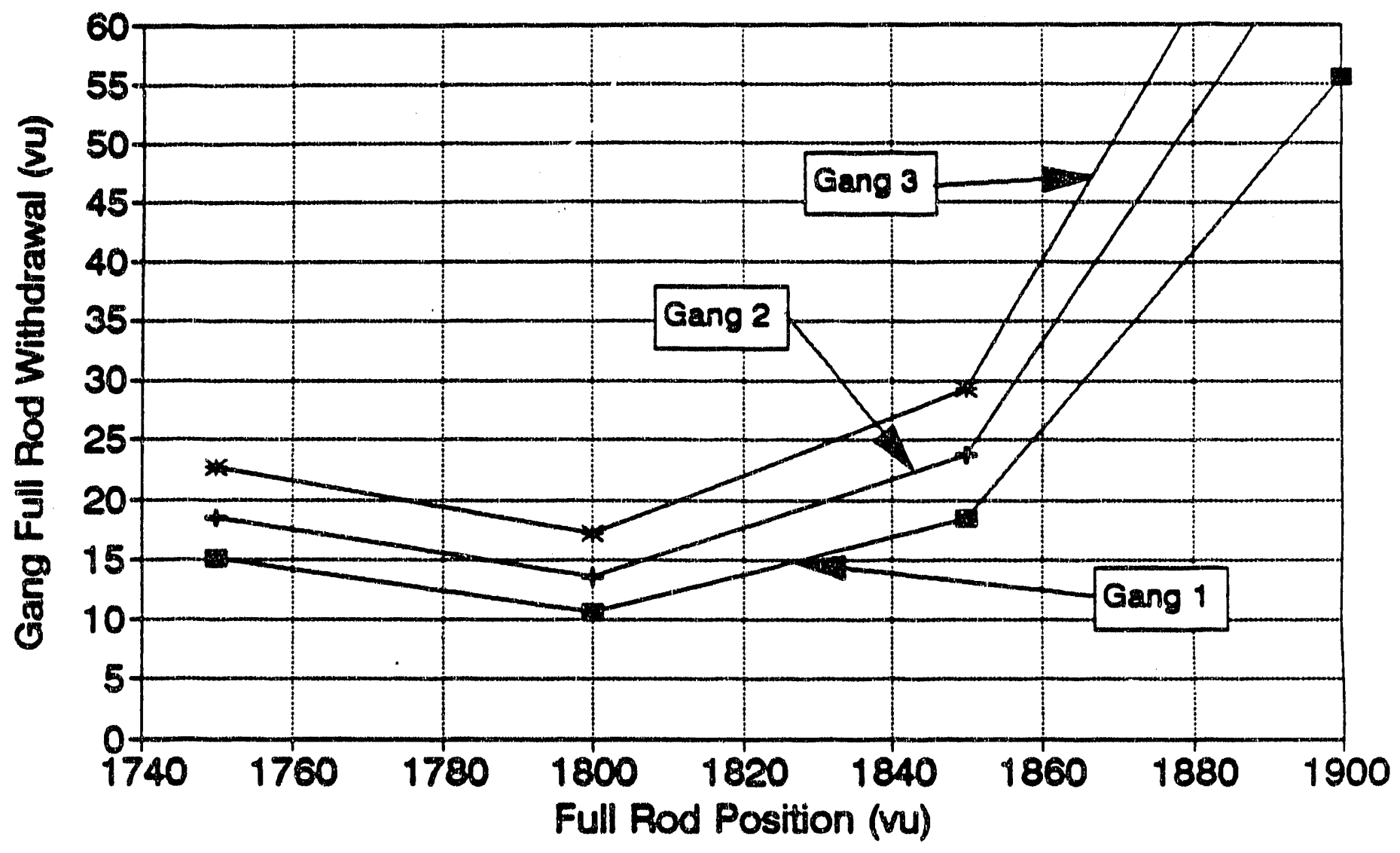


WSRC-TR-91-42-043

Page 42 of 138

June 4, 1991

FIGURE 14

\section{Full Rod Withdrawal - 10 PCM Reactivity Double Partial Rods at 800 vu}

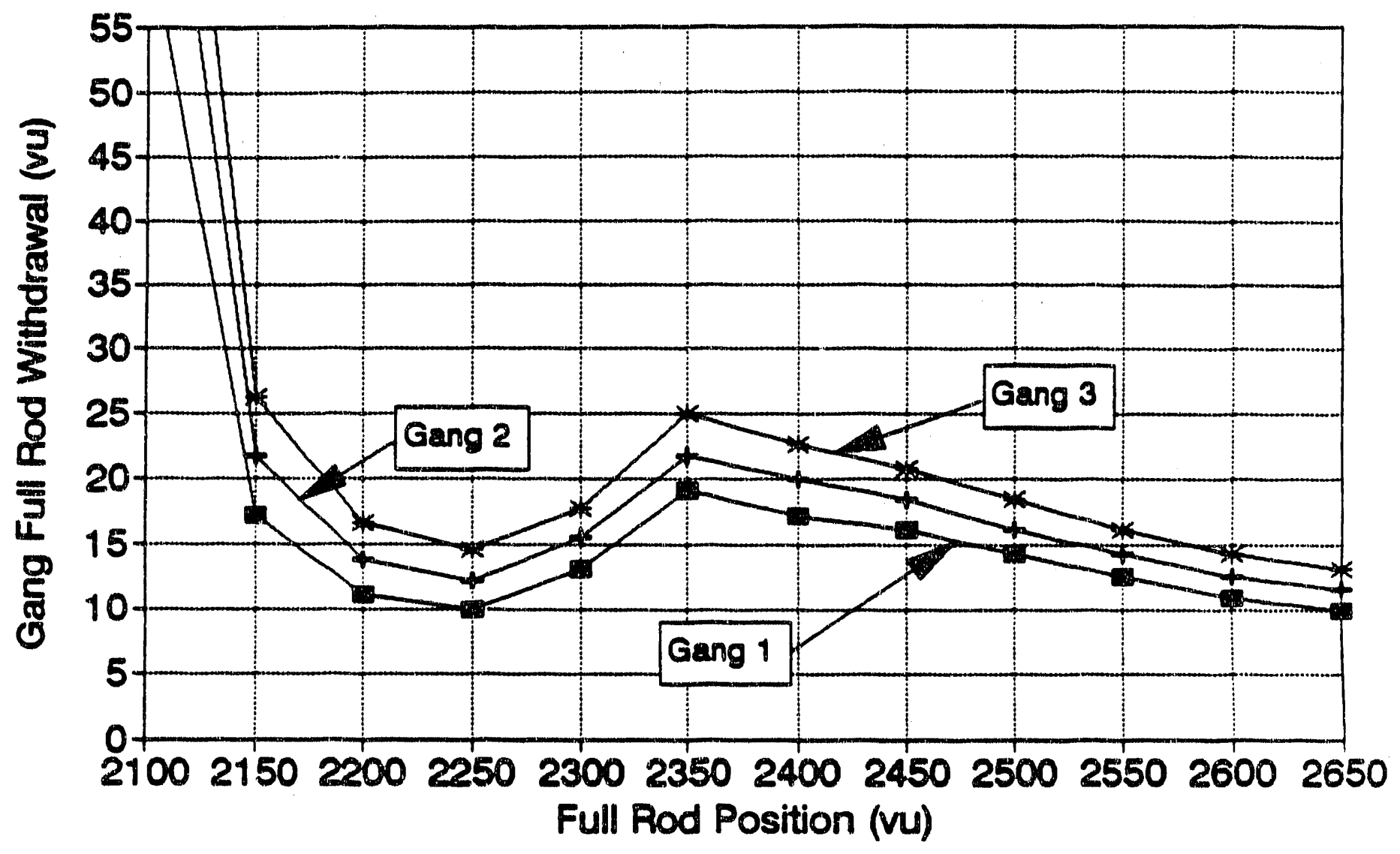


WSRC-TR-91-42-043

Page 43 of 133

June 4, 1991

FIGURE 15

\section{Full Rod Withdrawal - 20 PCM Reactivity Double Partial Rods at 800 vu}

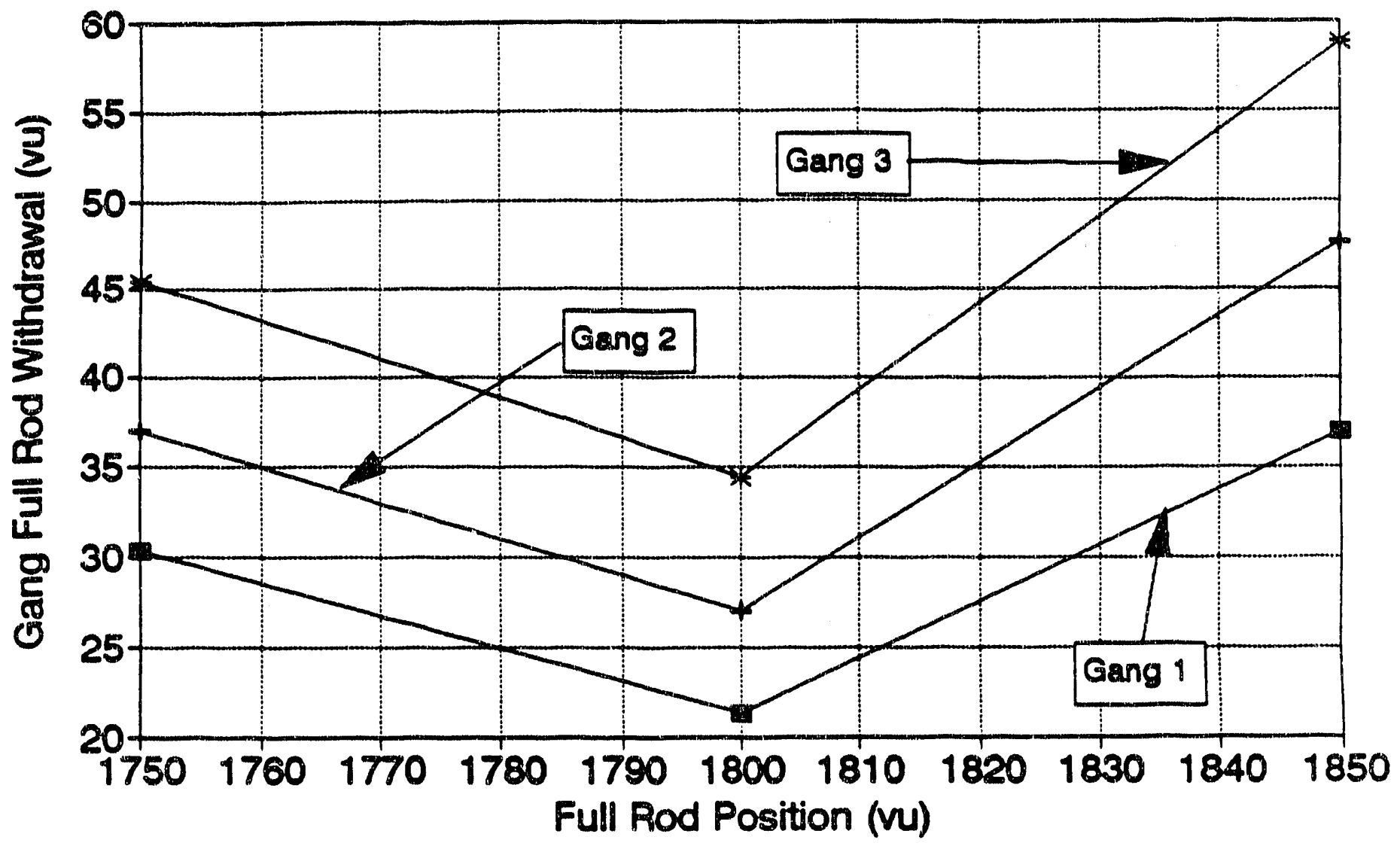


WSRC-TR-91-42-043

Page 44 of 138

June 4, 1991

FIGURE 16

\section{Full Rod Withdrawal - 20 PCM Reactivity Double Partial Rods at $800 \mathrm{vu}$}

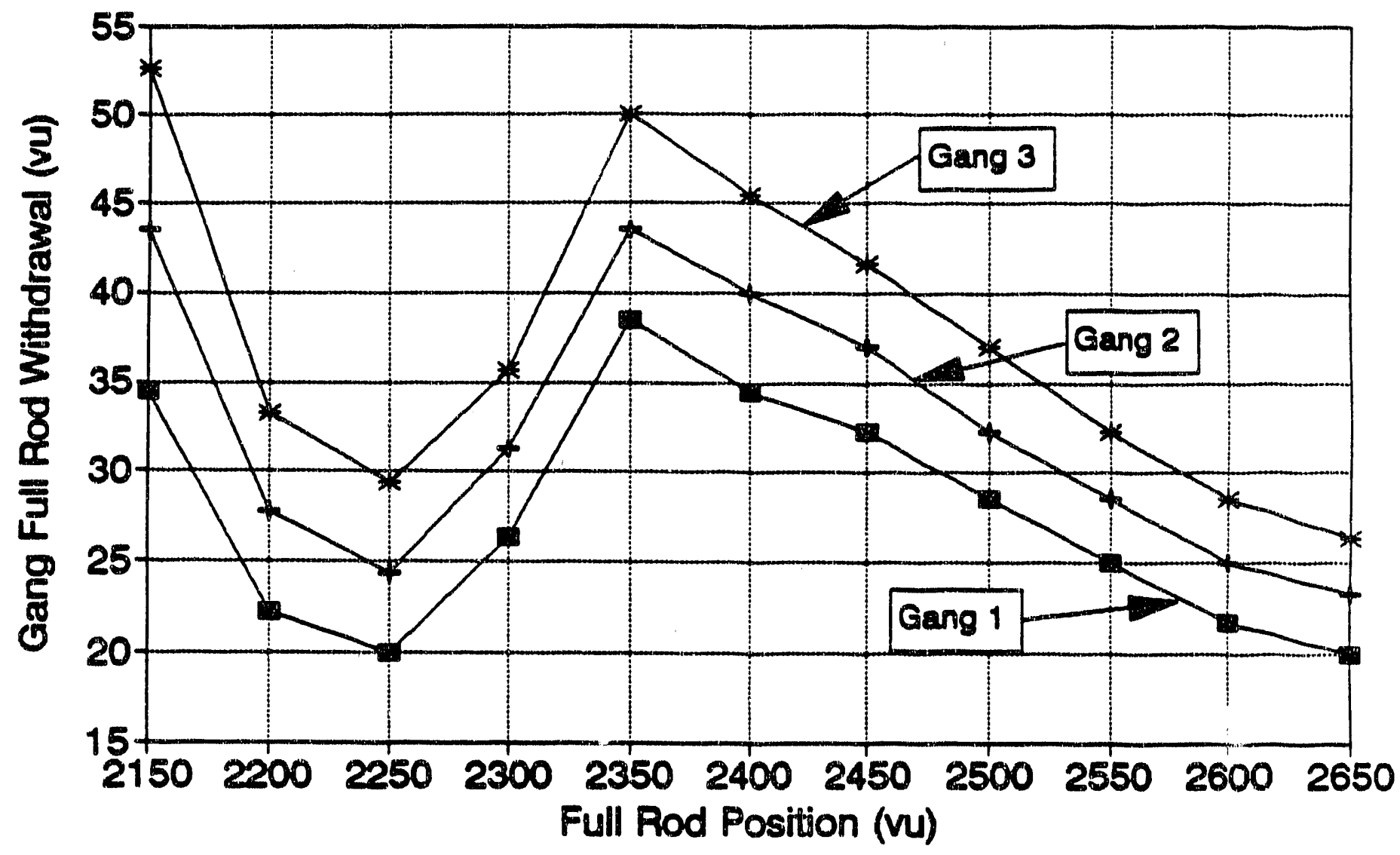


WSRC-TR-91-42-043

Page 45 of 138

June 4, 1991

FIGURE 17

\section{Full Rod Withdrawal - 30 PCM Reactivity Double Partial Rods at 800 vu}

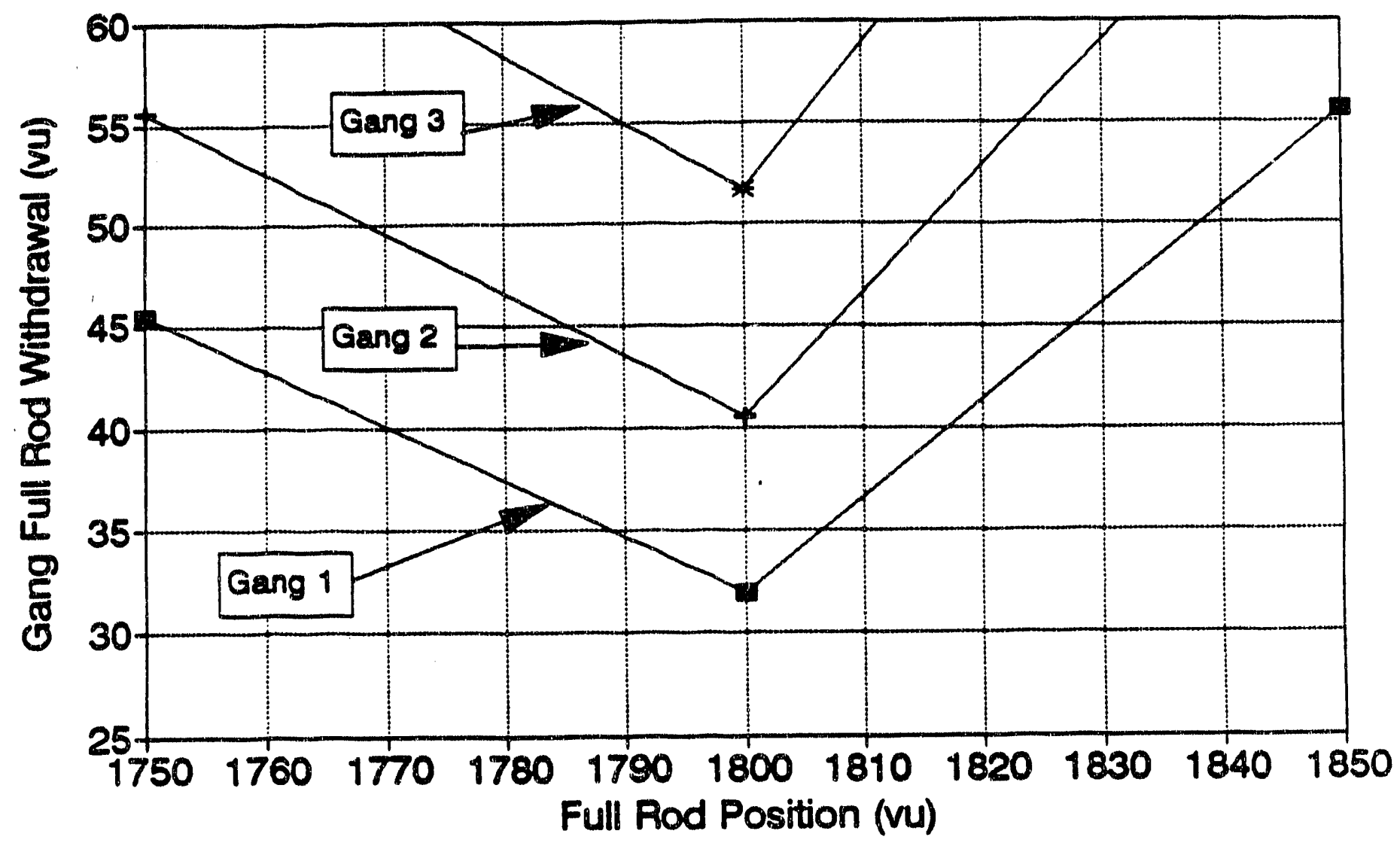


WSRC-TR-91-42-043

Page 46 of 138

June 4, 1991

FIGURE 18

\section{Full Rod Withdrawal - 30 PCM Reactivity Double Partial Rods at $800 \mathrm{vu}$}

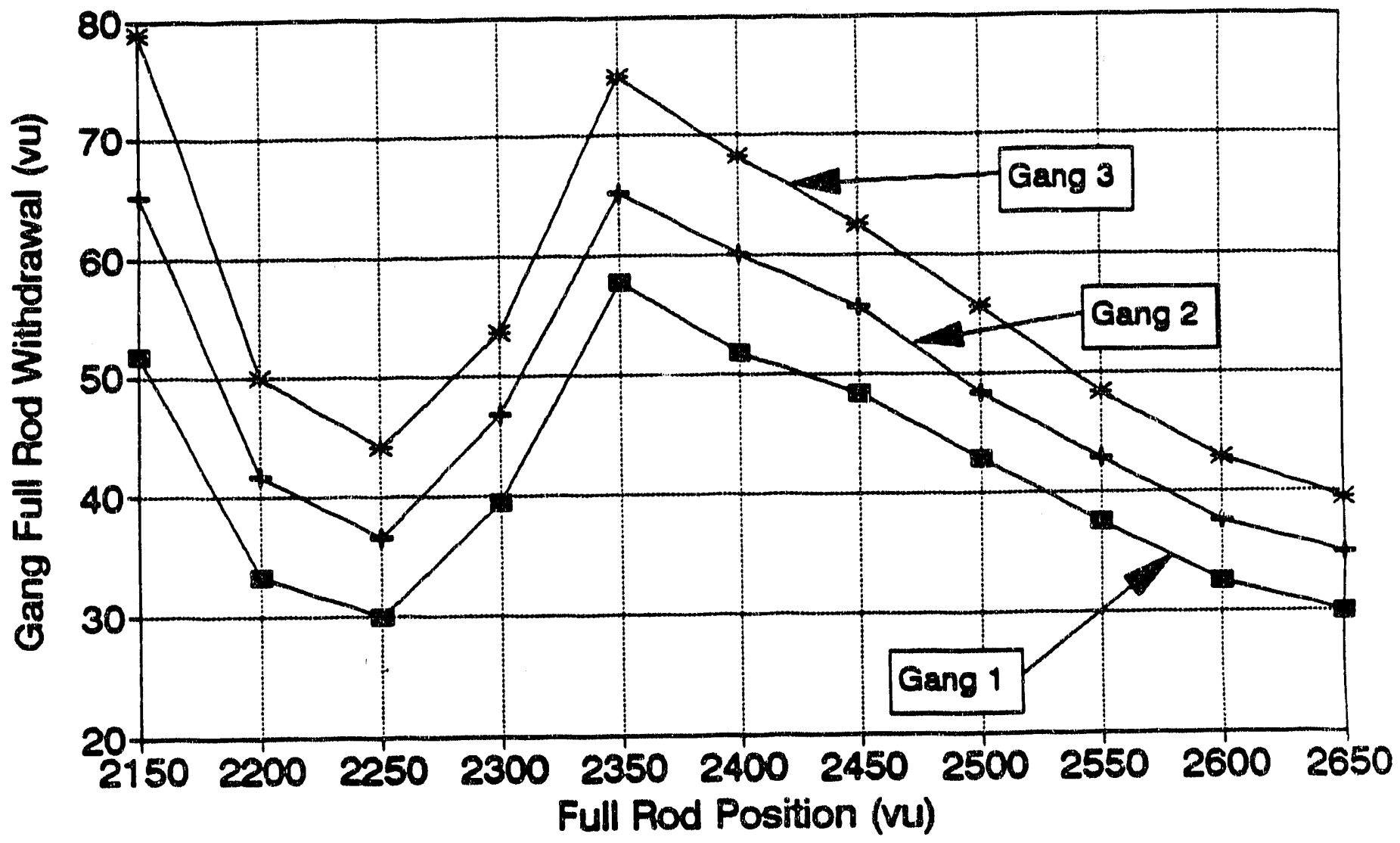


WSRC-TR-91-42-043

Page 47 of 138

June 4, 1991

FIGURE 19

\section{Full Rod Withdrawal - 10 PCM Reactivity Double Partial Rods at $700 \mathrm{vu}$}

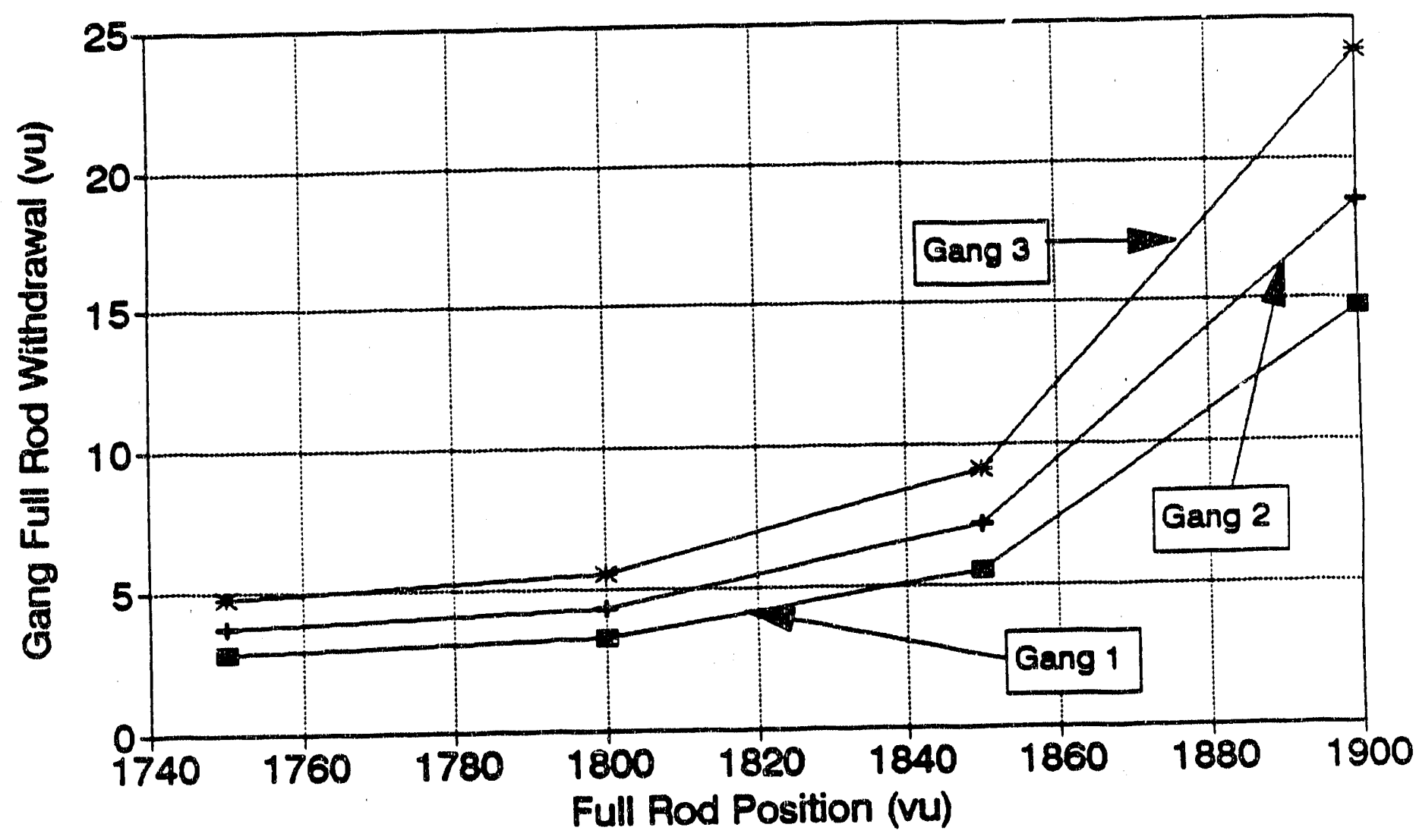


WSRC-TR-91-42-043

Page 48 of 138

June 4, 1991

FIGURE 20

\section{Full Rod Withdrawal - 10 PCM Reactivity Double Partial Rods at $700 \mathrm{vu}$}

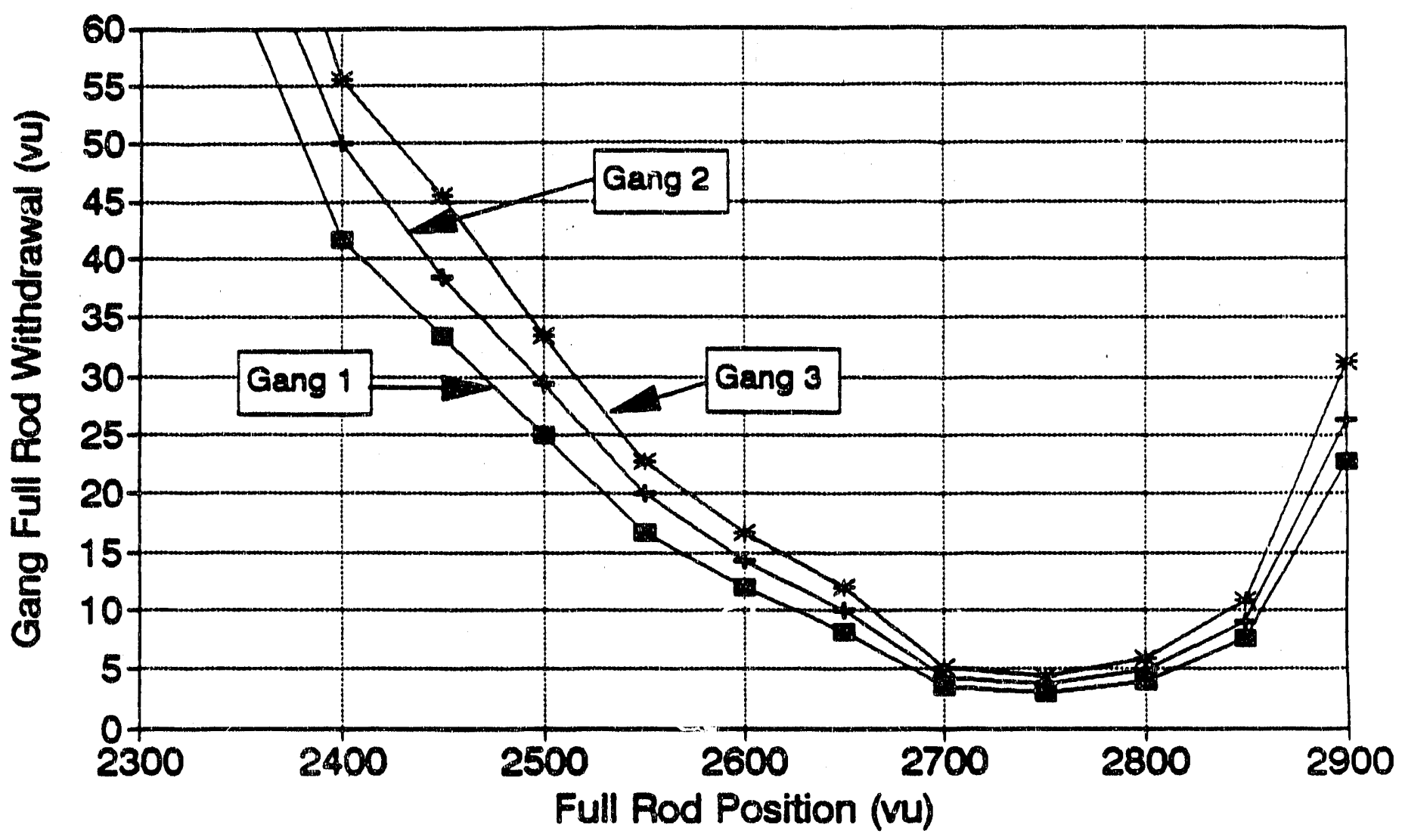


WSRC-TR-91-42-043

Page 49 of 138

June 4, 1991

FIGURE 21

Full Rod Withdrawal - 10 PCM Reactivity Double Partial Rods at $700 \mathrm{vu}$

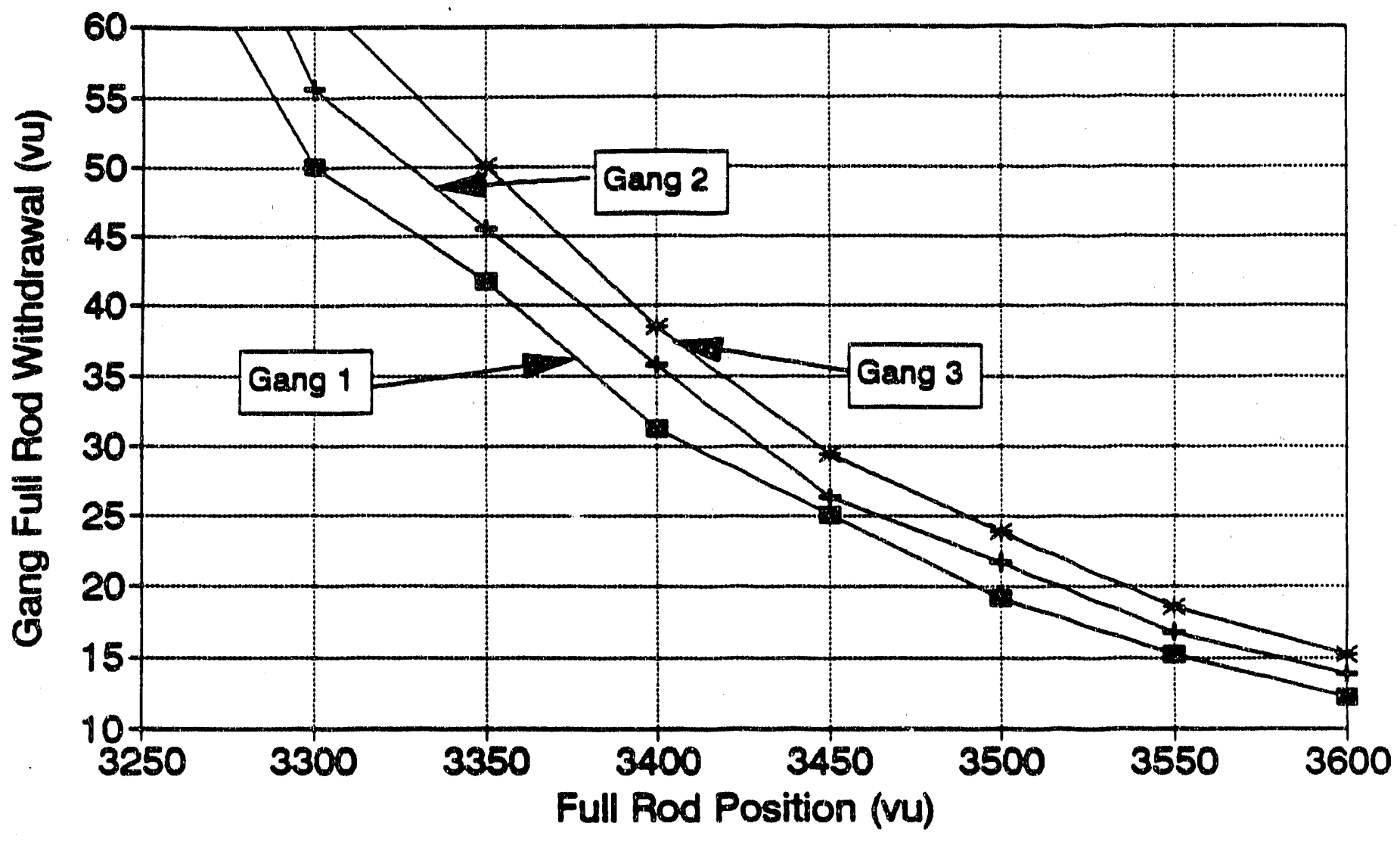


WSRC-TR-91-42-043

Page 50 of 138

June 4, 1991

FIGURE 22

\section{Full Rod Withdrawal - 20 PCM Reactivity Double Partial Rods at $700 \mathrm{vu}$}

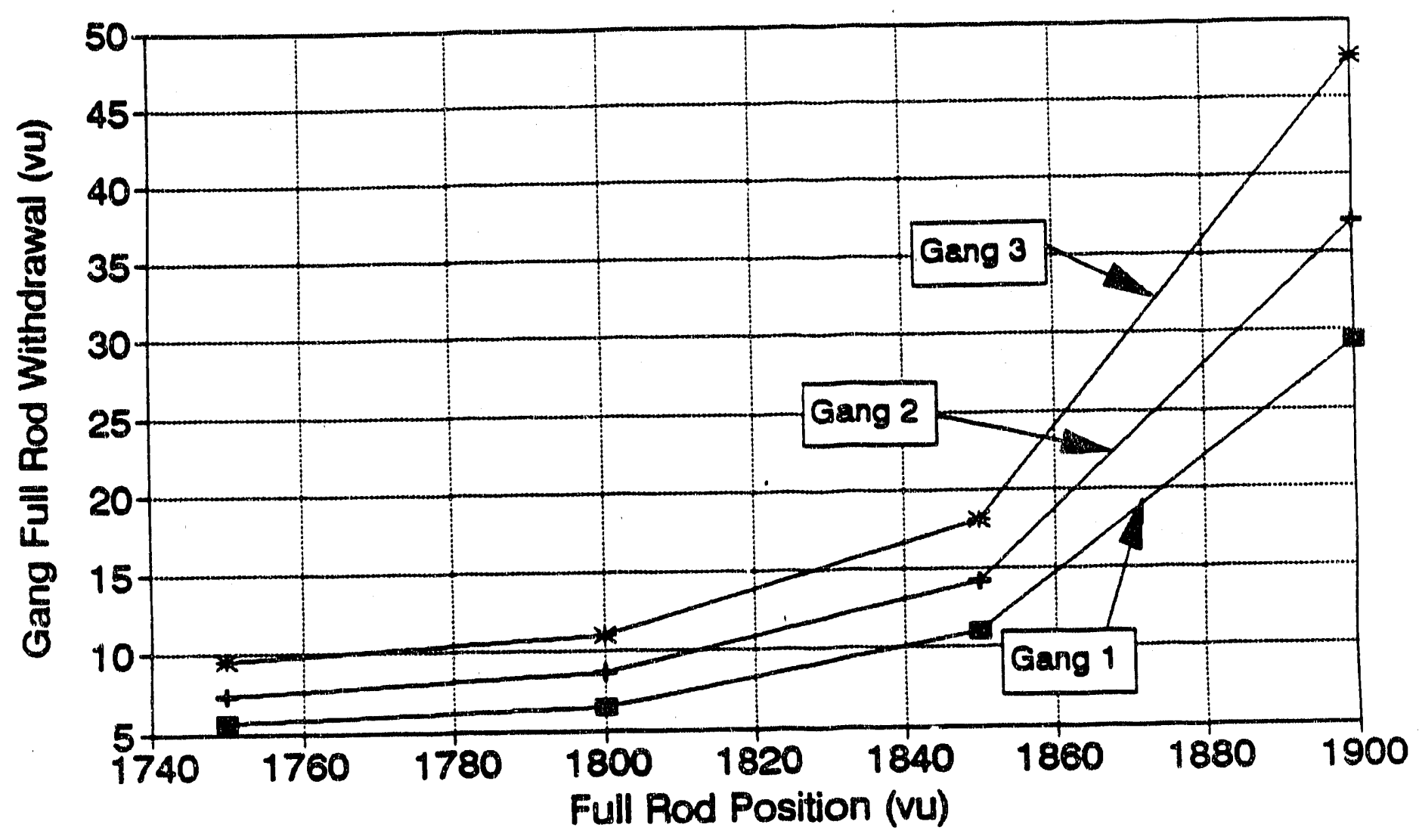


WSRC-TR-91-42-043

Page 51 of 138

June 4, 1991

FIGURE 23

\section{Full Rod Withdrawal - 20 PCM Reactivity Double Partial Rods at 700 vu}

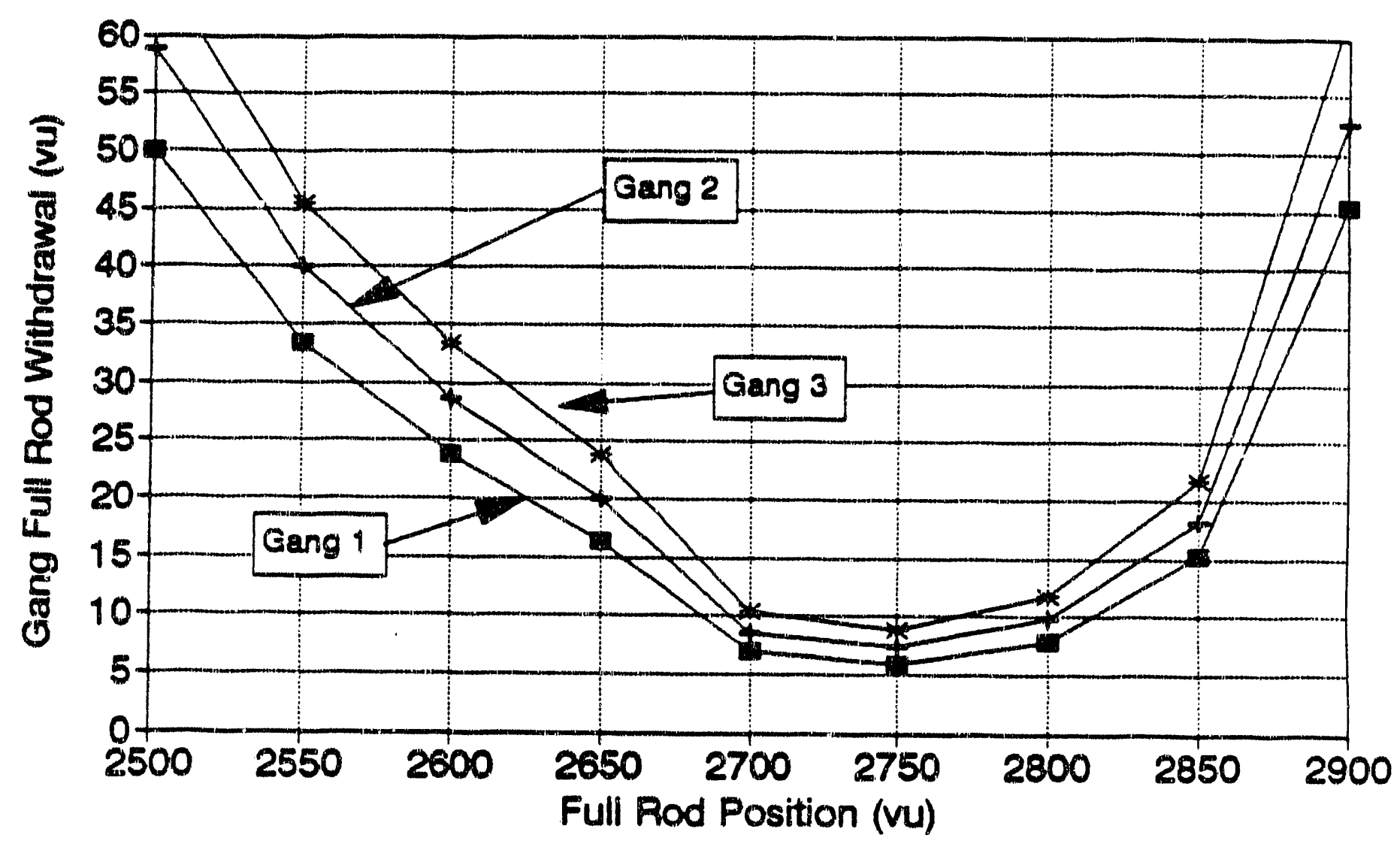


WSRC-TR-91-42-043

Page 52 of 138

Junie 4, 1991

FIGURE 24

Full Rod Withdrawal - 20 PCM Reactivity Double Partial Rods at 700 vu

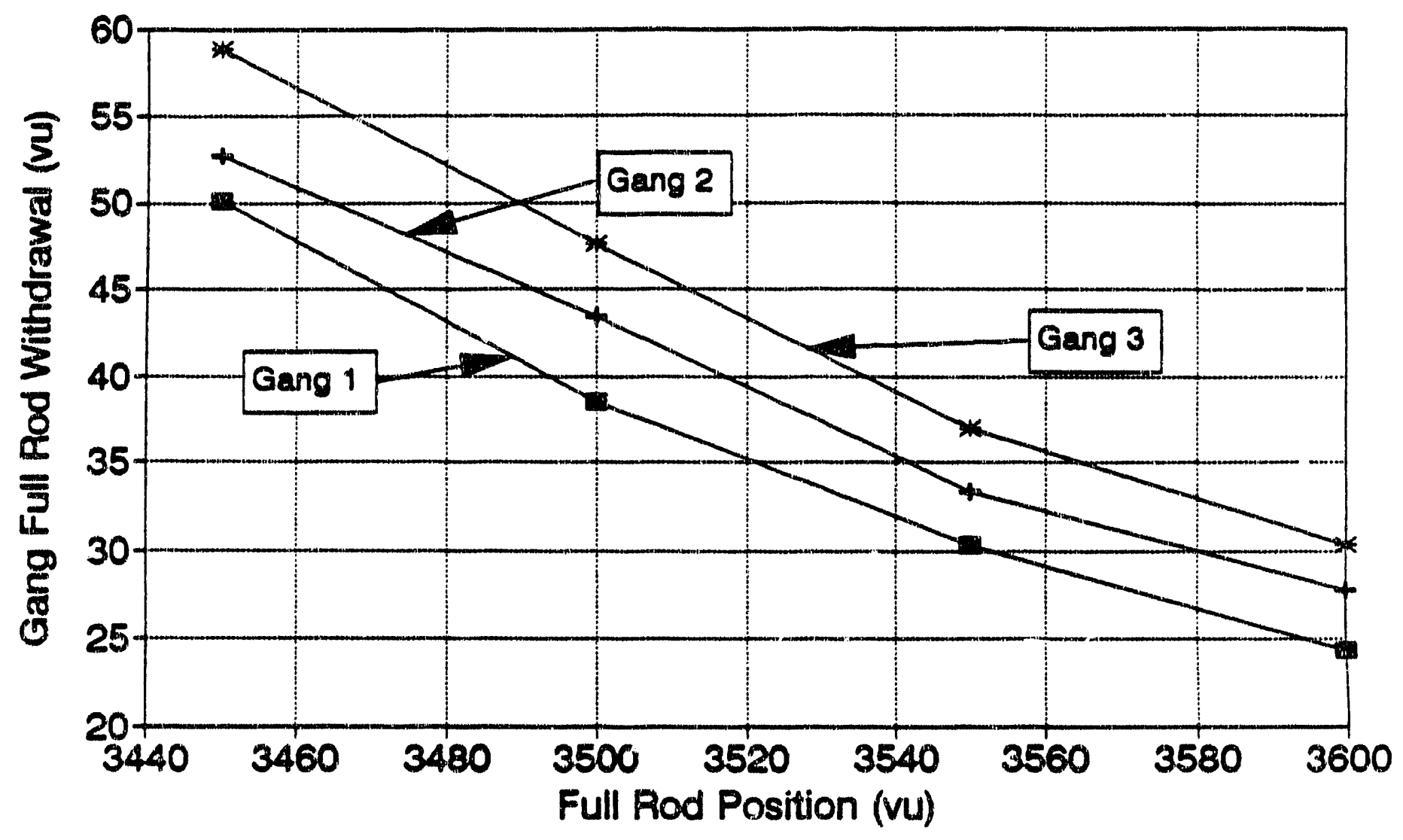


WSRC-TR-91-42-043

Page 53 of 138

June 4, 1991

FIGURE 25

Full Rod Withdrawal - 30 PCM Reactivity
Double Partial Rods at $700 \mathrm{vu}$

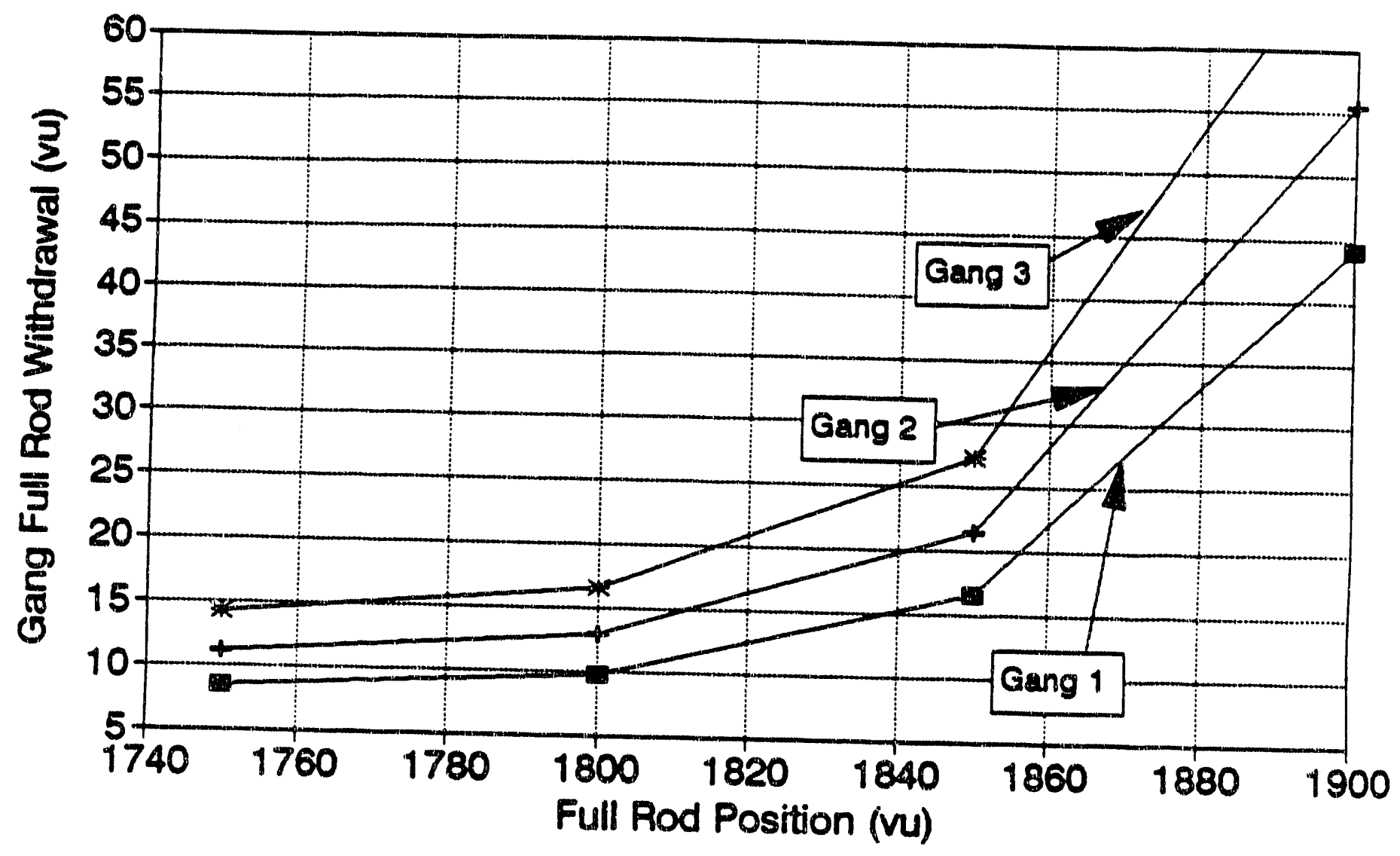


WSRC-TR-91-42-043

Page 54 of 138

June 4, 1991

FIGURE 26

Full Rod Withdrawal - 30 PCM Reactivity Double Partial Rods at $700 \mathrm{vu}$

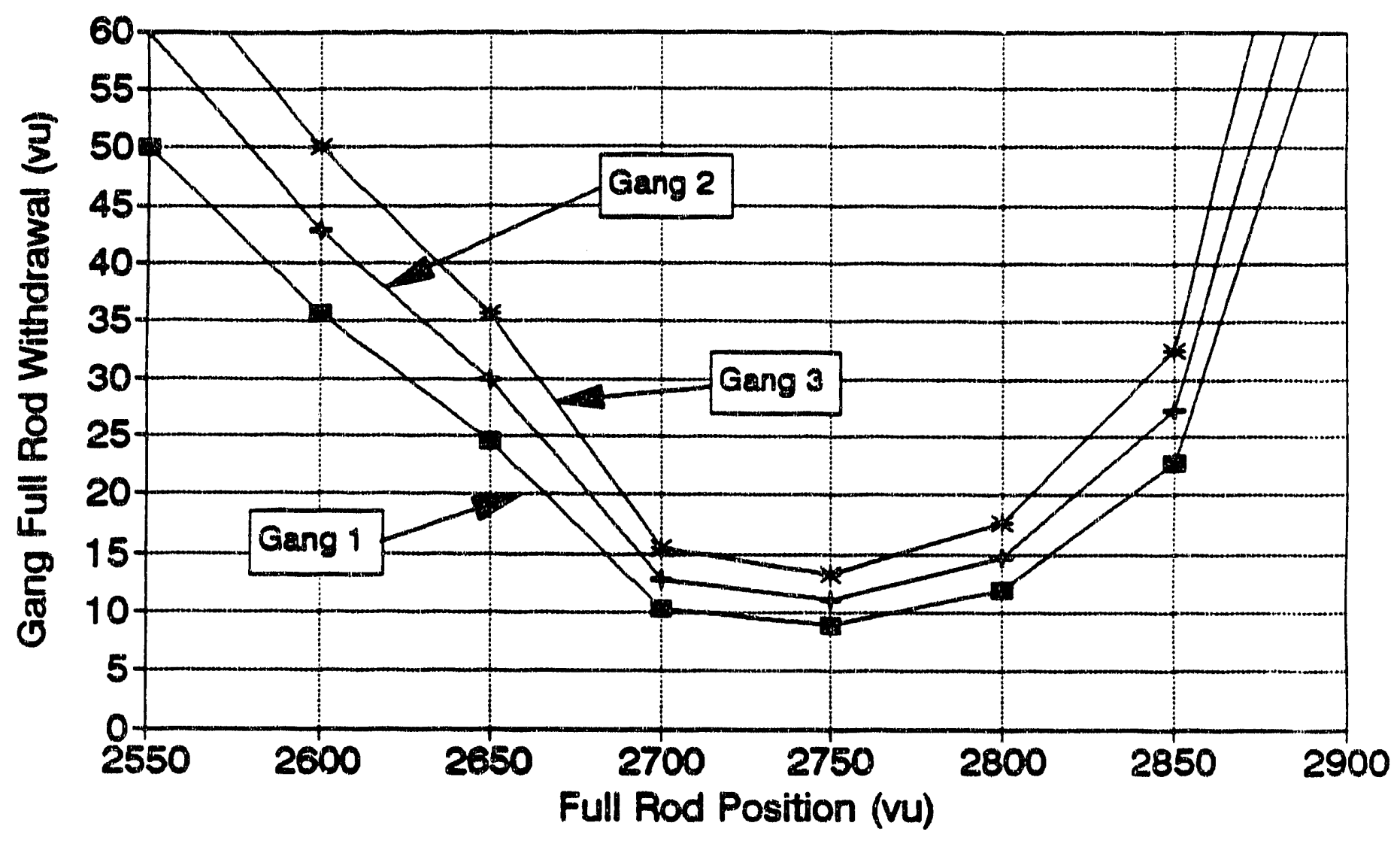


WSRC-TR- $91-42-043$

Page 55 of 138

June 4, 1991

FIGURE 27

\section{Full Rod Withdrawal - 30 PCM Reactivity Double Partial Rods at 700 vu}

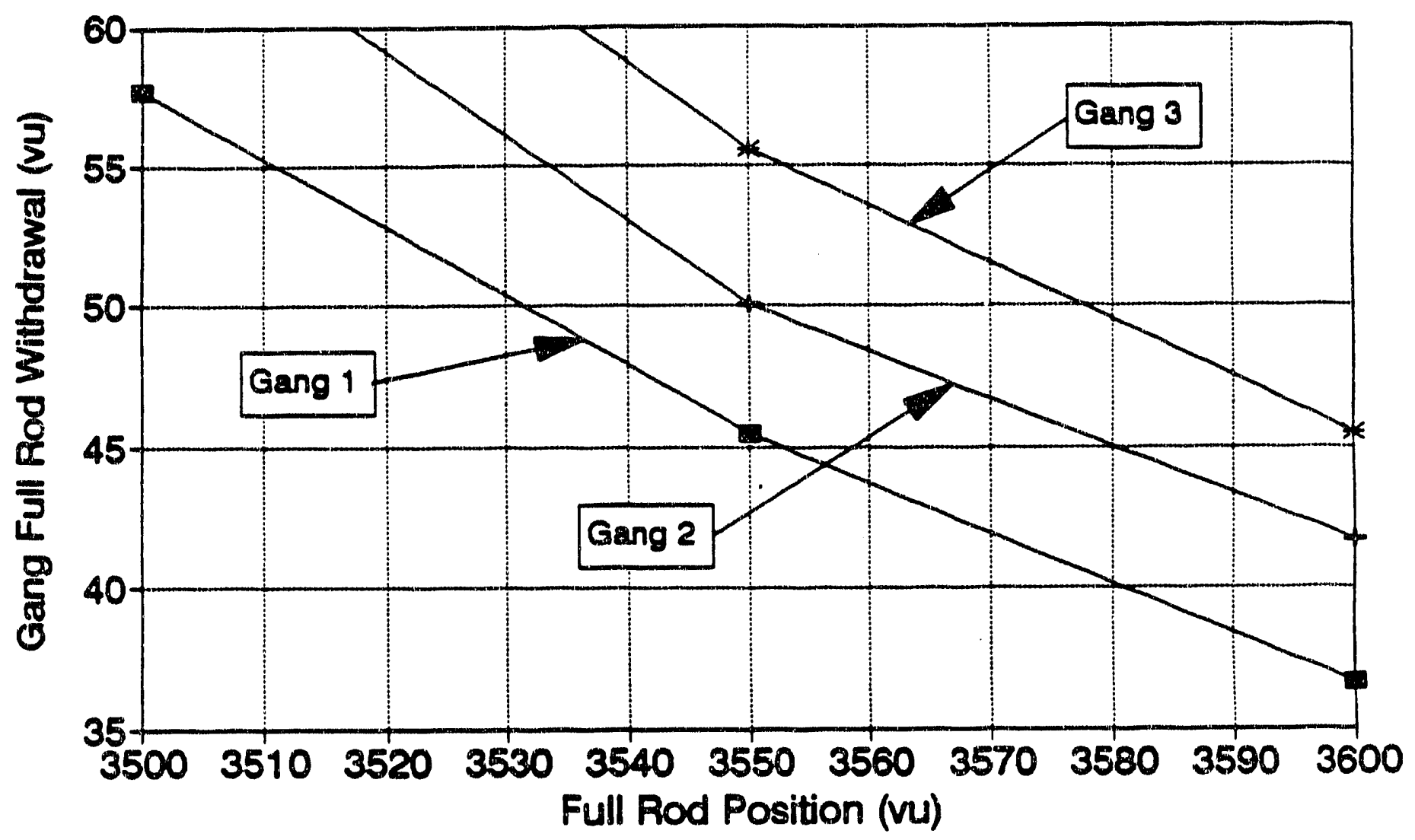


WSRC-TR-91-42-043

Page 56 of 138

June 4, 1991

FIGURE 28

\section{Full Rod Withdrawal - 10 PCM Reactivity Double Partial Rods at $950 \mathrm{vu}$}

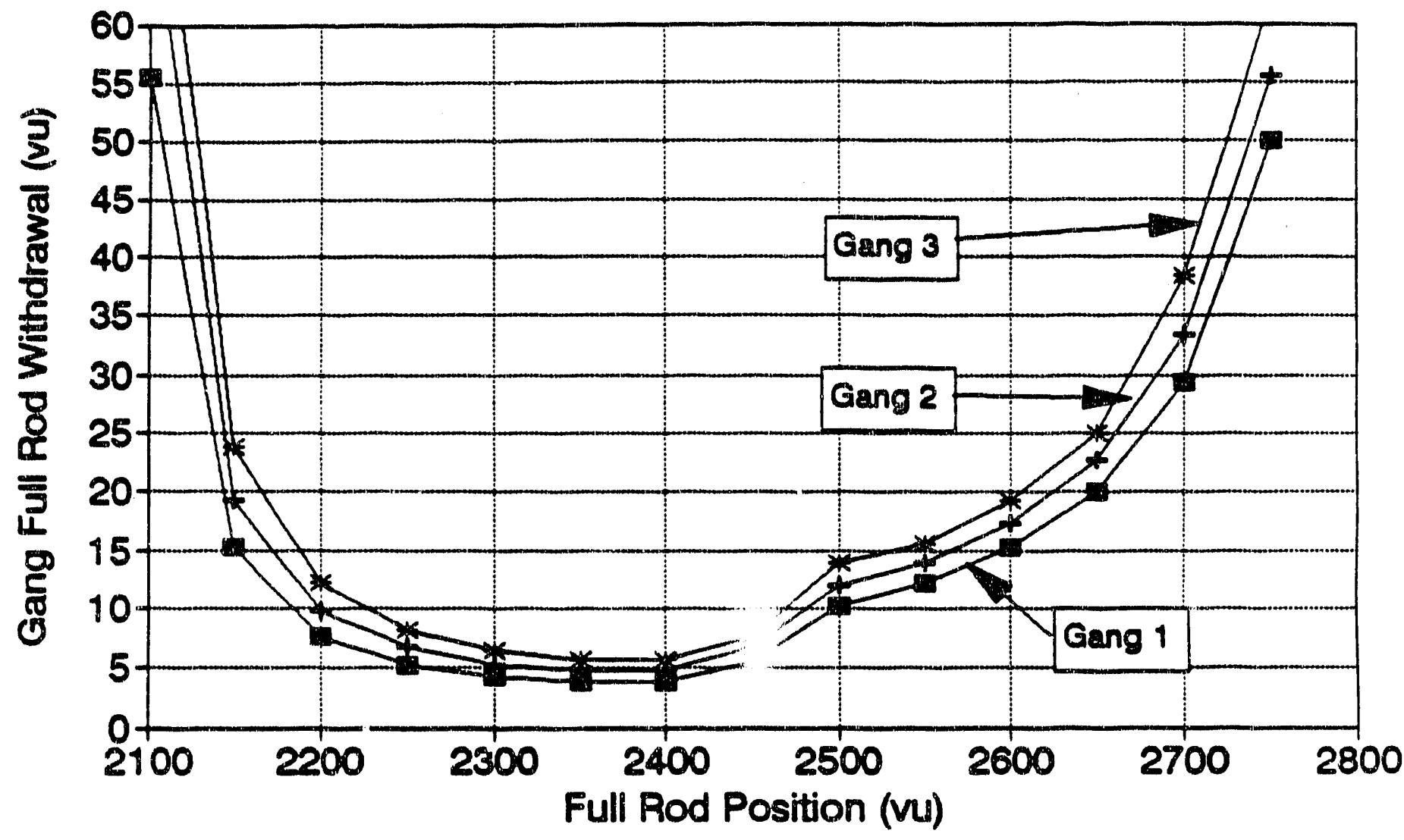


WSRC-TR-91-42-043

Page 57 of 138

June \&, 1991

FIGURE 29

\section{Full Rod Withdrawal - 10 PCM Reactivity Double Partial Rods at $950 \mathrm{vu}$}

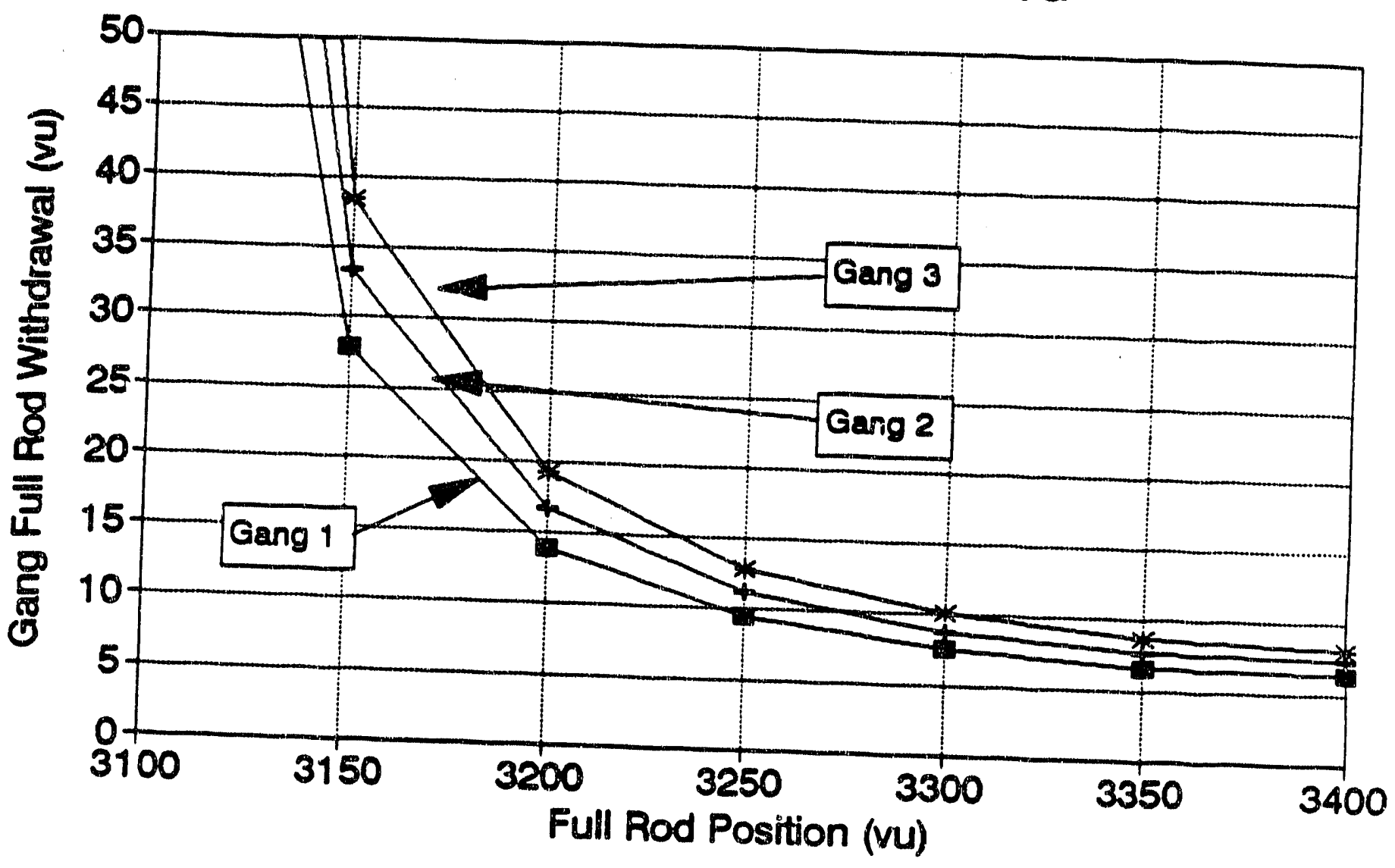


WSRC-TR-91-42-043

Page 58 of 138

June 4, 1991

FIGURE 30

Full Rod Withdrawal - 20 PCM Reactivity Double Partial Rods at $950 \mathrm{vu}$

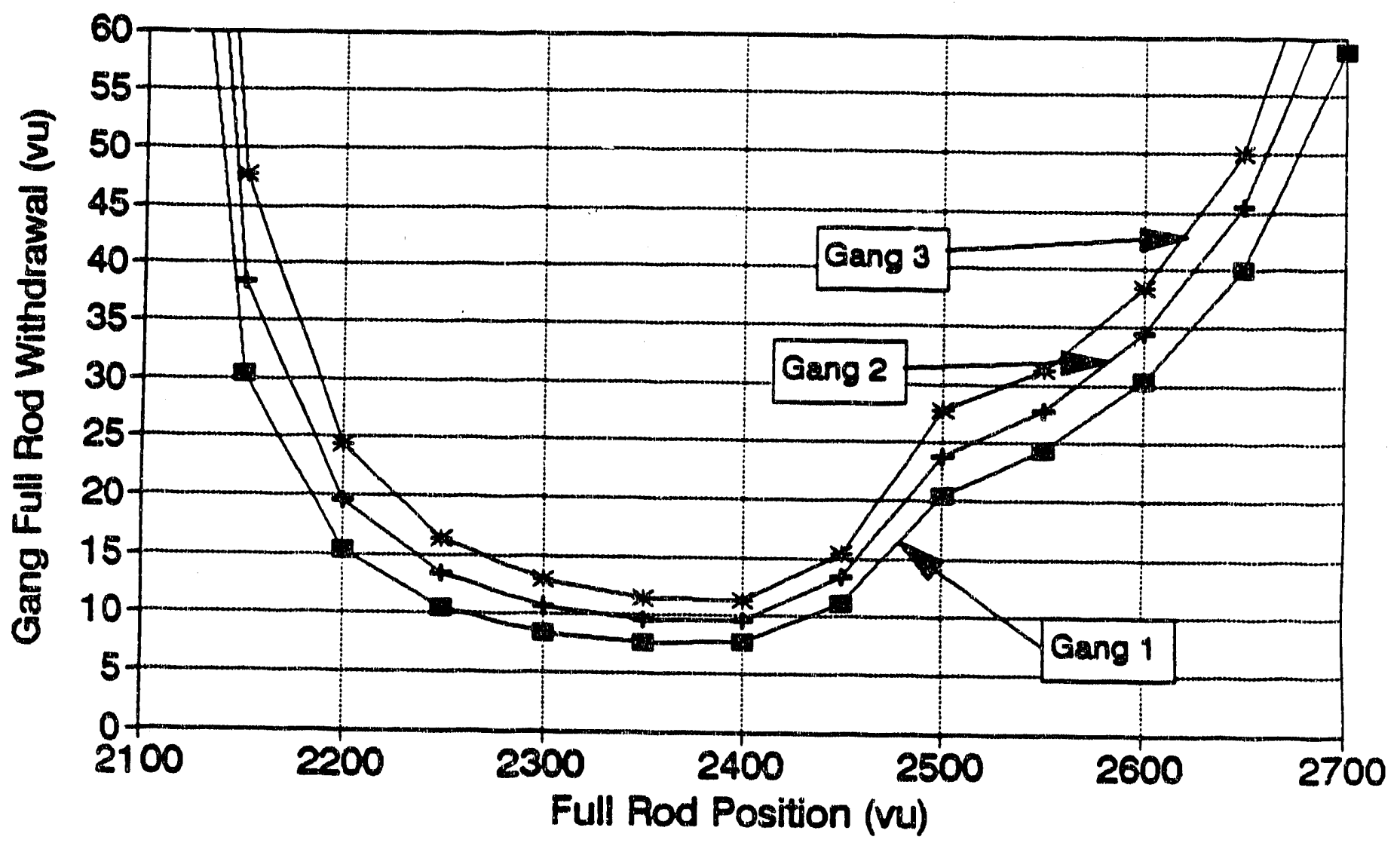


WSRC-TR-91-42-043

Page 59 of 138

June 4, 1991

FIGURE 31

\section{Full Rod Withdrawal - 20 PCM Reactivity Double Partial Rods at $950 \mathrm{vu}$}

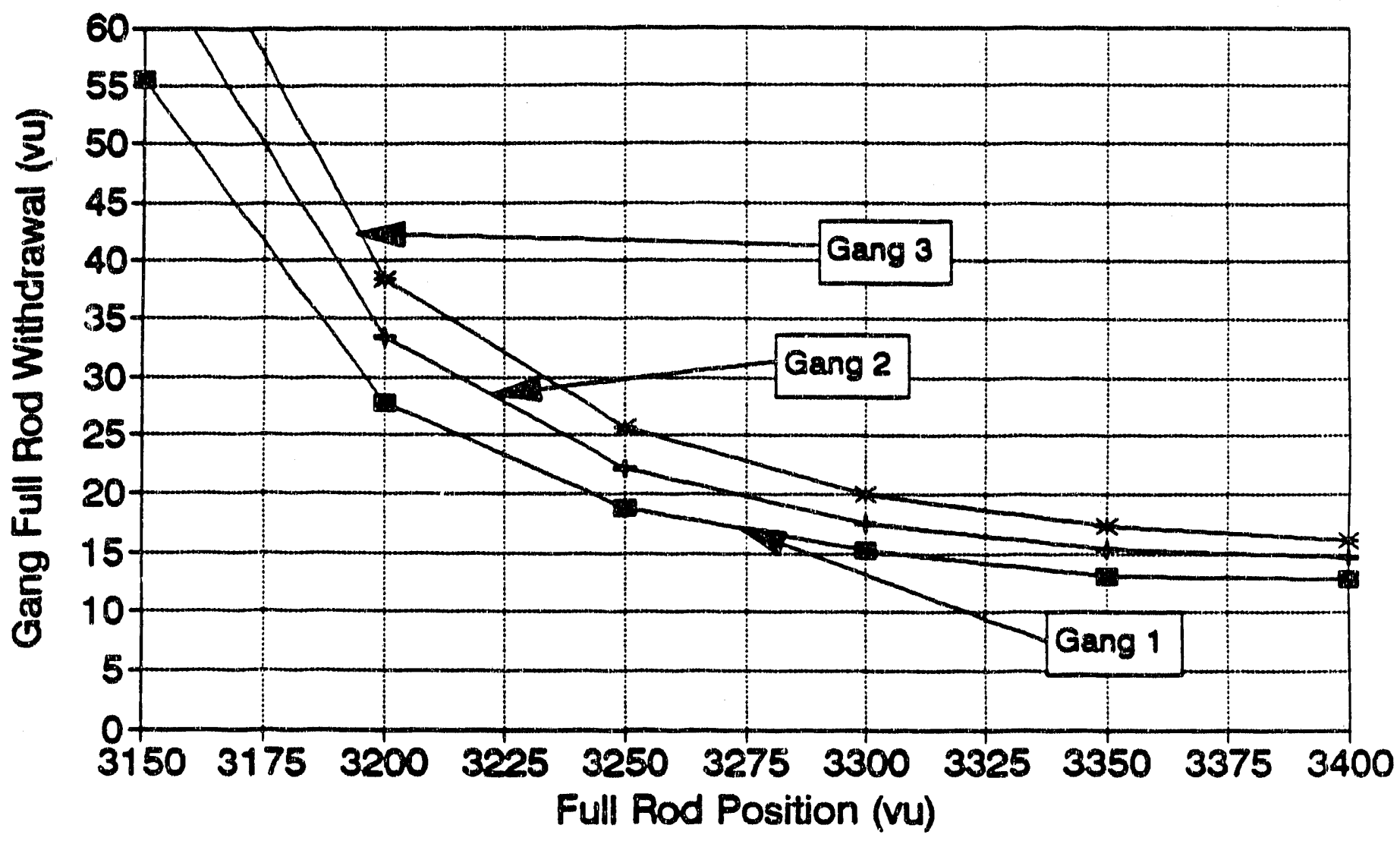


FIGURIE 32

\section{Full Rod Withdrawal - 30 PCM Reactivity Double Partial Rods at $950 \mathrm{vu}$}

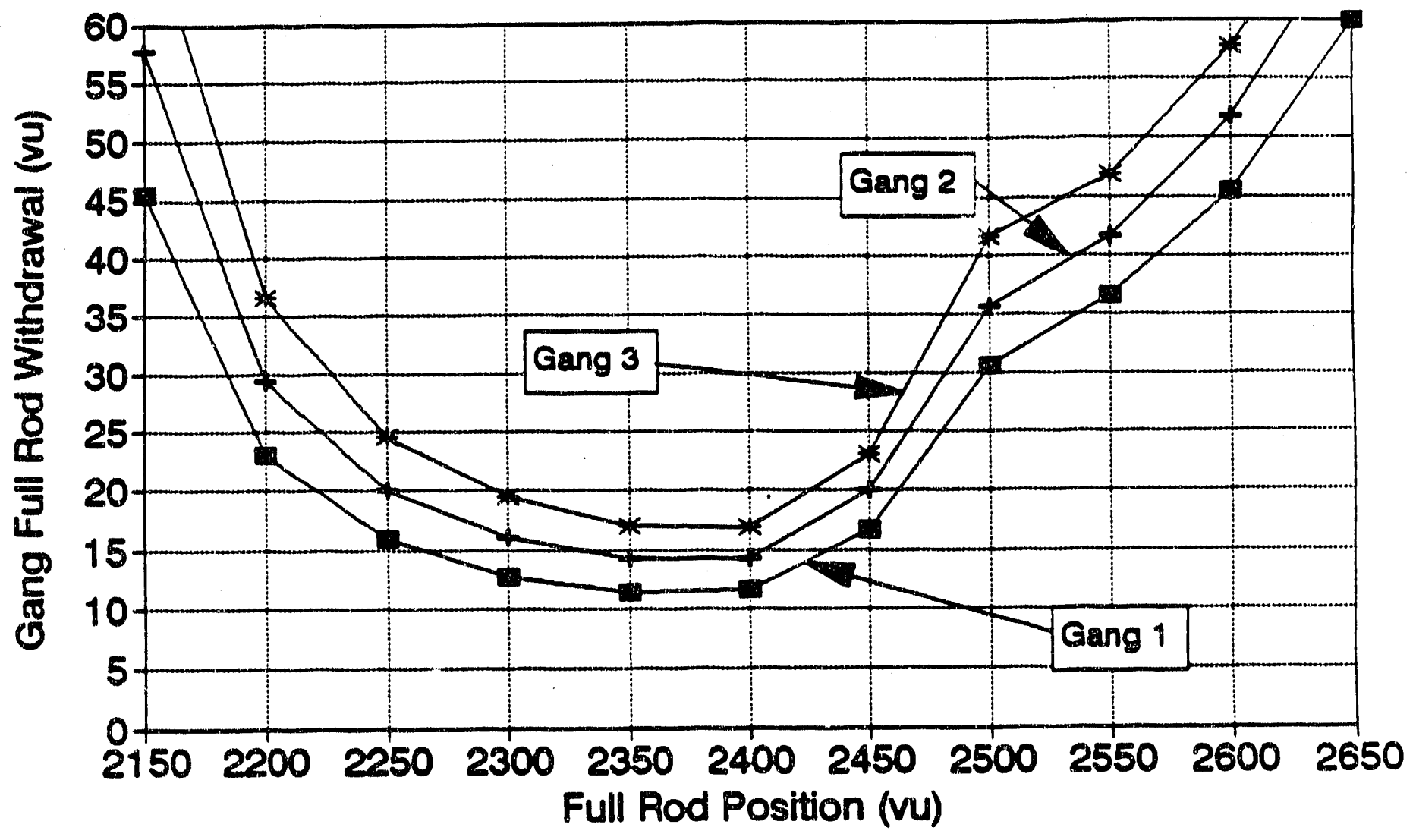


WSRC-TR-91-42-043

Page 61 of 138

June 4, 1991

FIGURE 33

\section{Full Rod Withdrawal - 30 PCM Reactivity Double Partial Rods at $950 \mathrm{vu}$}

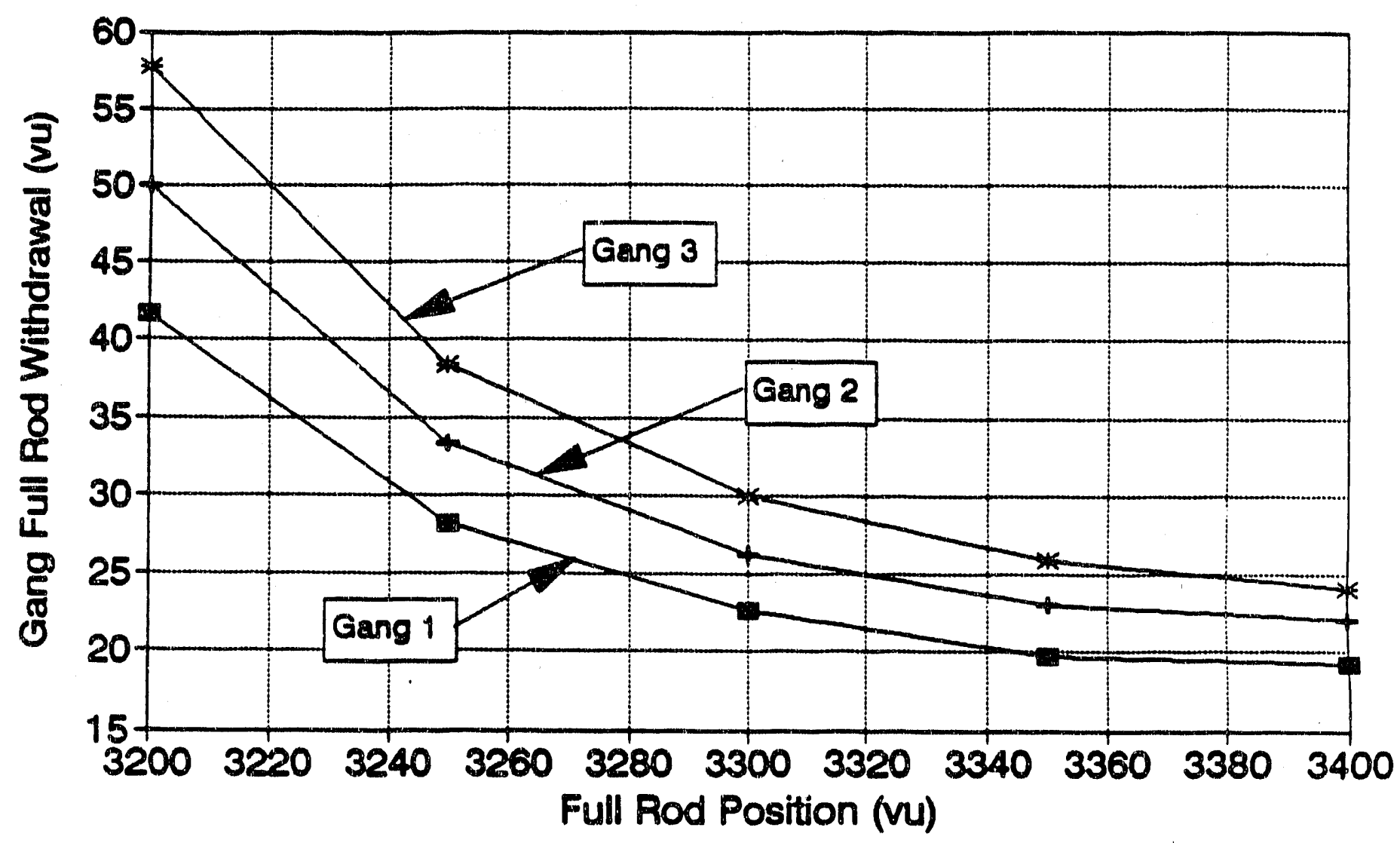


WSRC-TR-91-42-043

Page 62 of 138

June 4, 1991

FIGUAE 34

\section{Full Rod Withdrawal - 10 PCM Reactivity Weak Partial Rods at $800 \mathrm{vu}$}

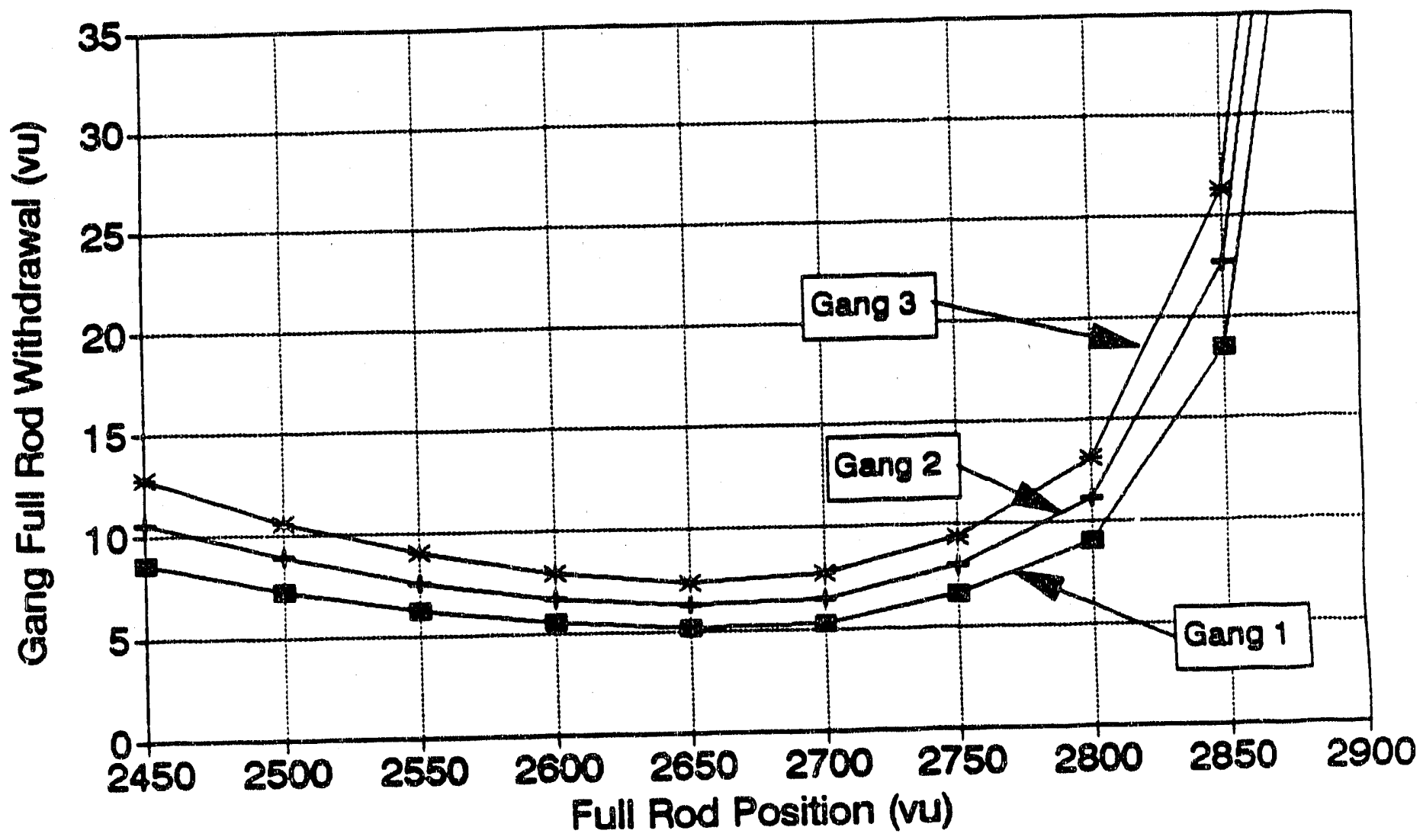


WSRC-TR-91-42-043

Page 63 of 138

June 4, 1991

FIGURE 35

\section{Full Rod Withdrawal - 10 PCM Reactivity Weak Partial Rods at $800 \mathrm{vu}$}

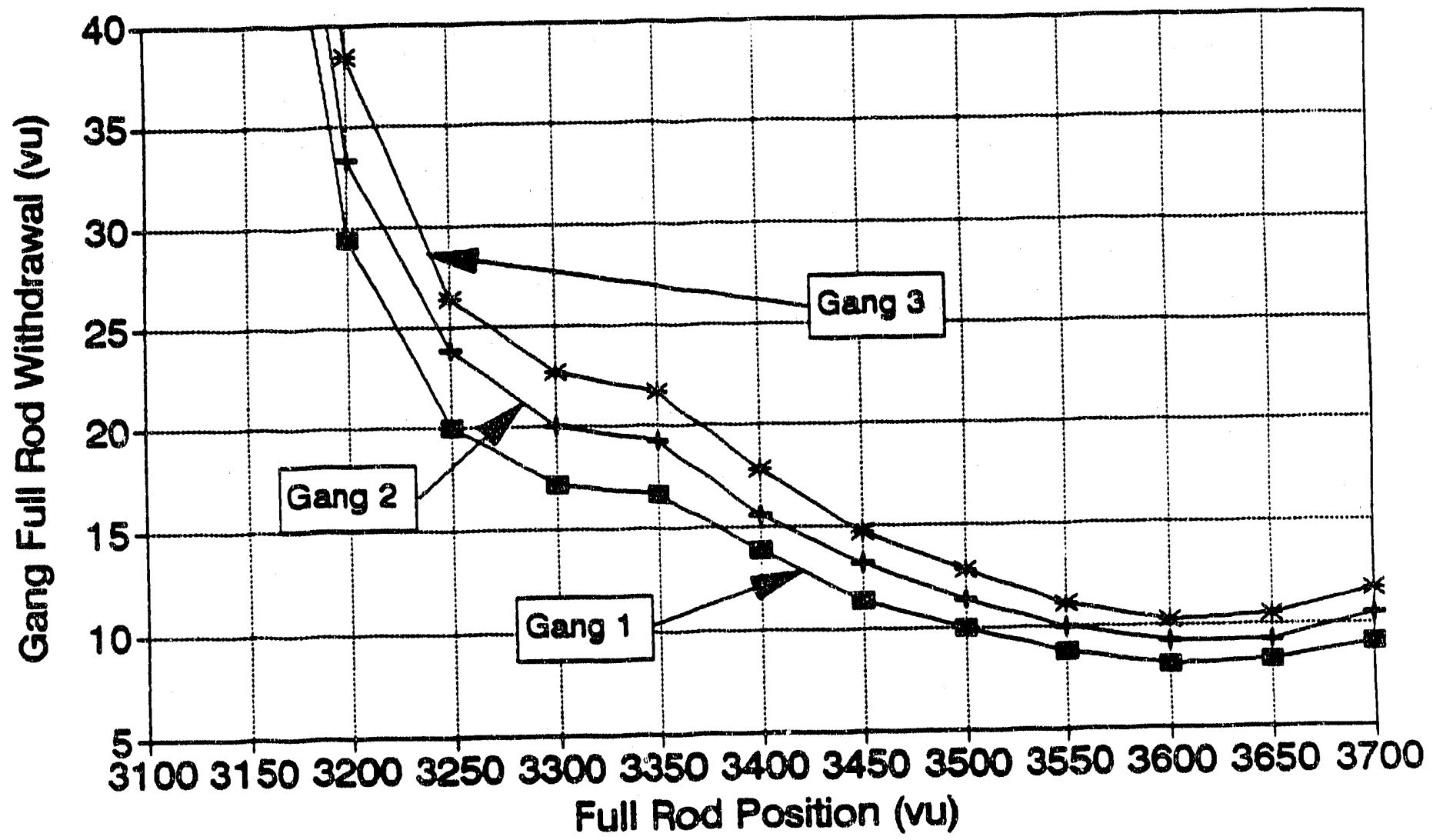


WSRC-TR-91-42-043

Page 64 of 138

June 4, 1991

FIGURE 36

\section{Full Rod Withdrawal - 20 PCM Reactivity Weak Partial Rods at $800 \mathrm{vu}$}

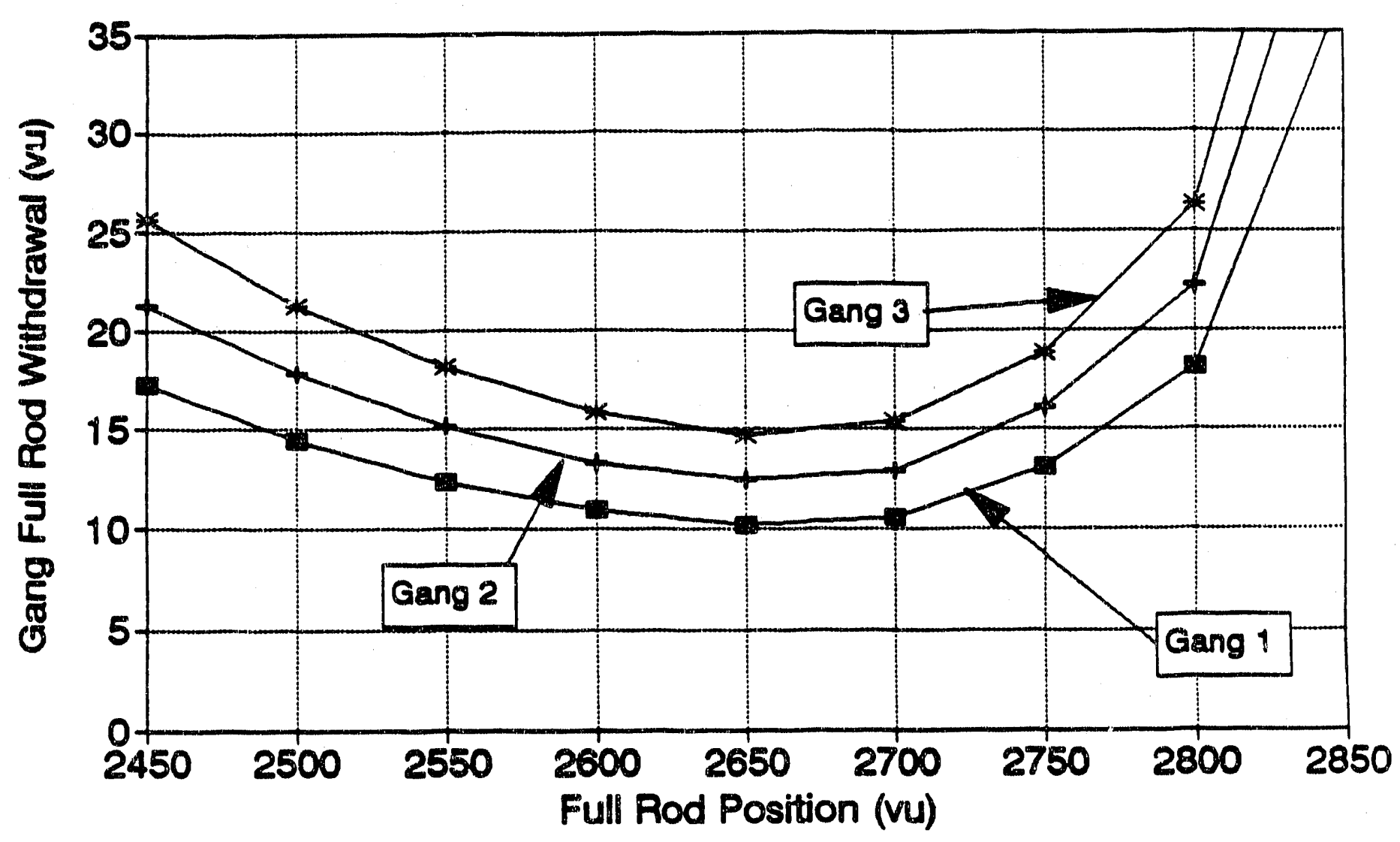


WSRC-TR-91-42-043

Page 65 of 138

June 4, 1991

FIGURE 37

\section{Full Rod Withdrawal - 20 PCM Reactivity Weak Partial Rods at $800 \mathrm{vu}$}

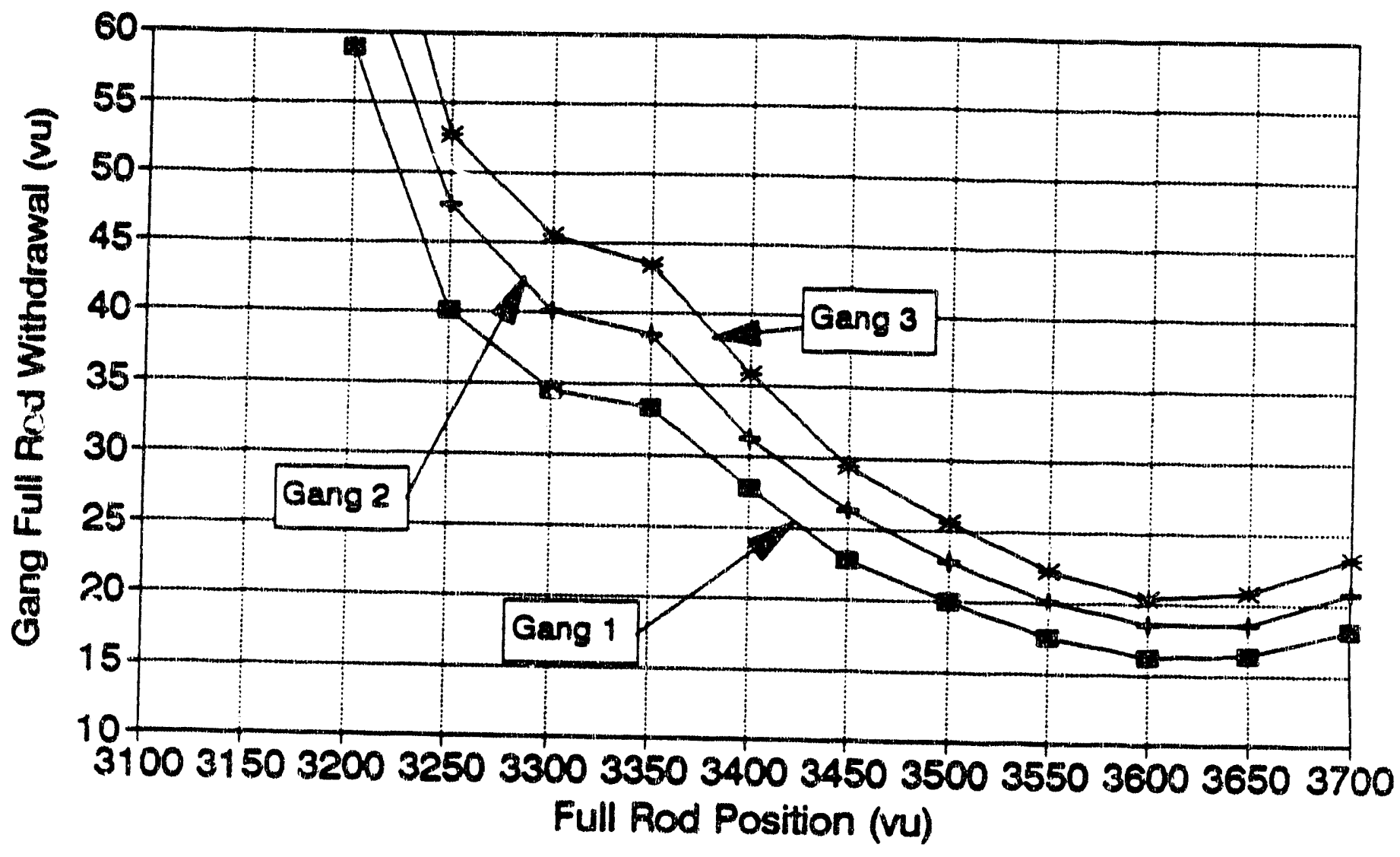


WSRC-TR-91-42-043

Page 66 of 138

June 4, 1991

FIGURE 38

\section{Full Rod Withdrawal - 30 PCM Reactivity Weak Partial Rods at 800 vu}

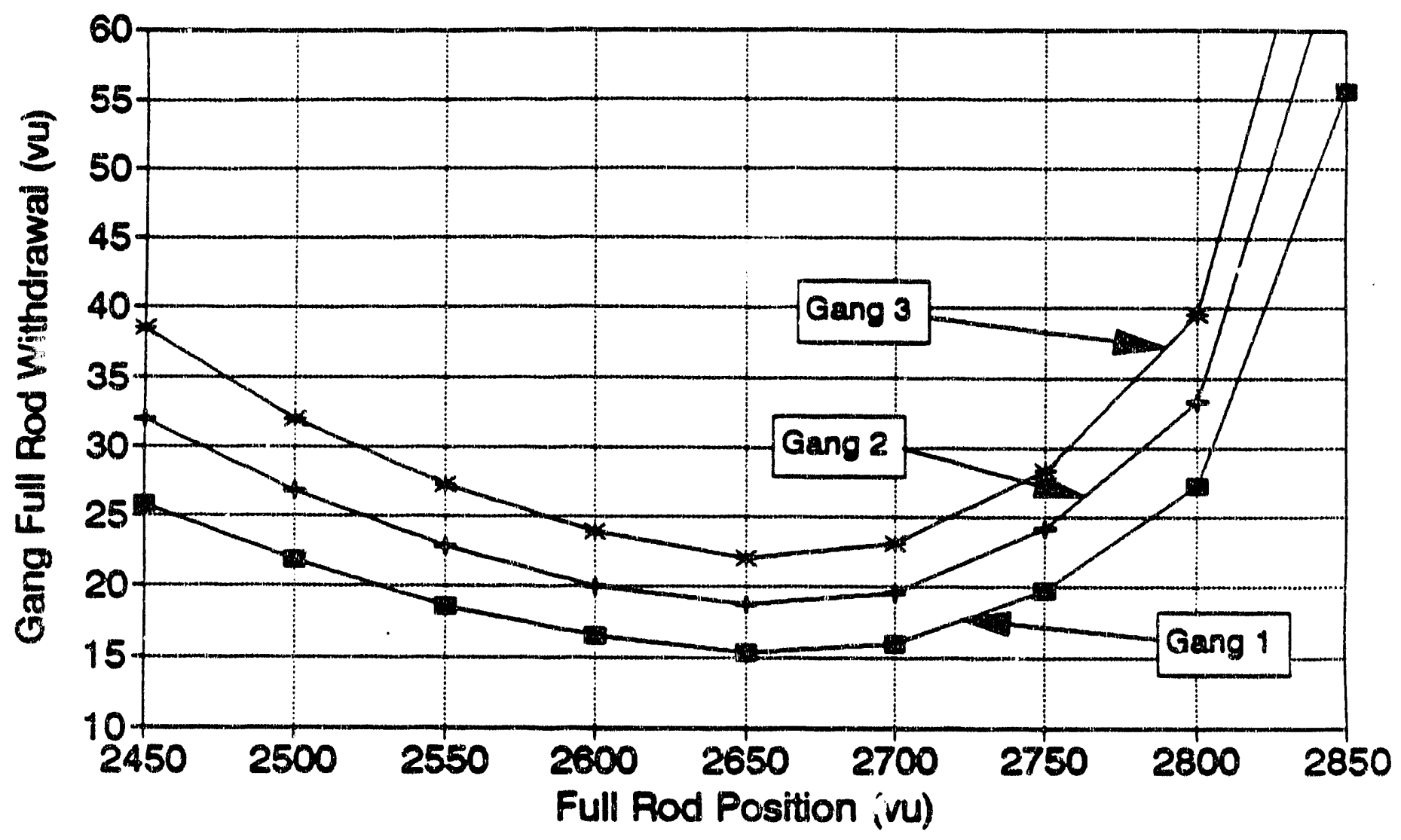


WSRC-TR-91-42-043

Page 67 of 138

June 4, 1991

FIGURE 39

\section{Full Rod Withdrawal - 30 PCM Reactivity Weak Partial Rods at 800 vu}

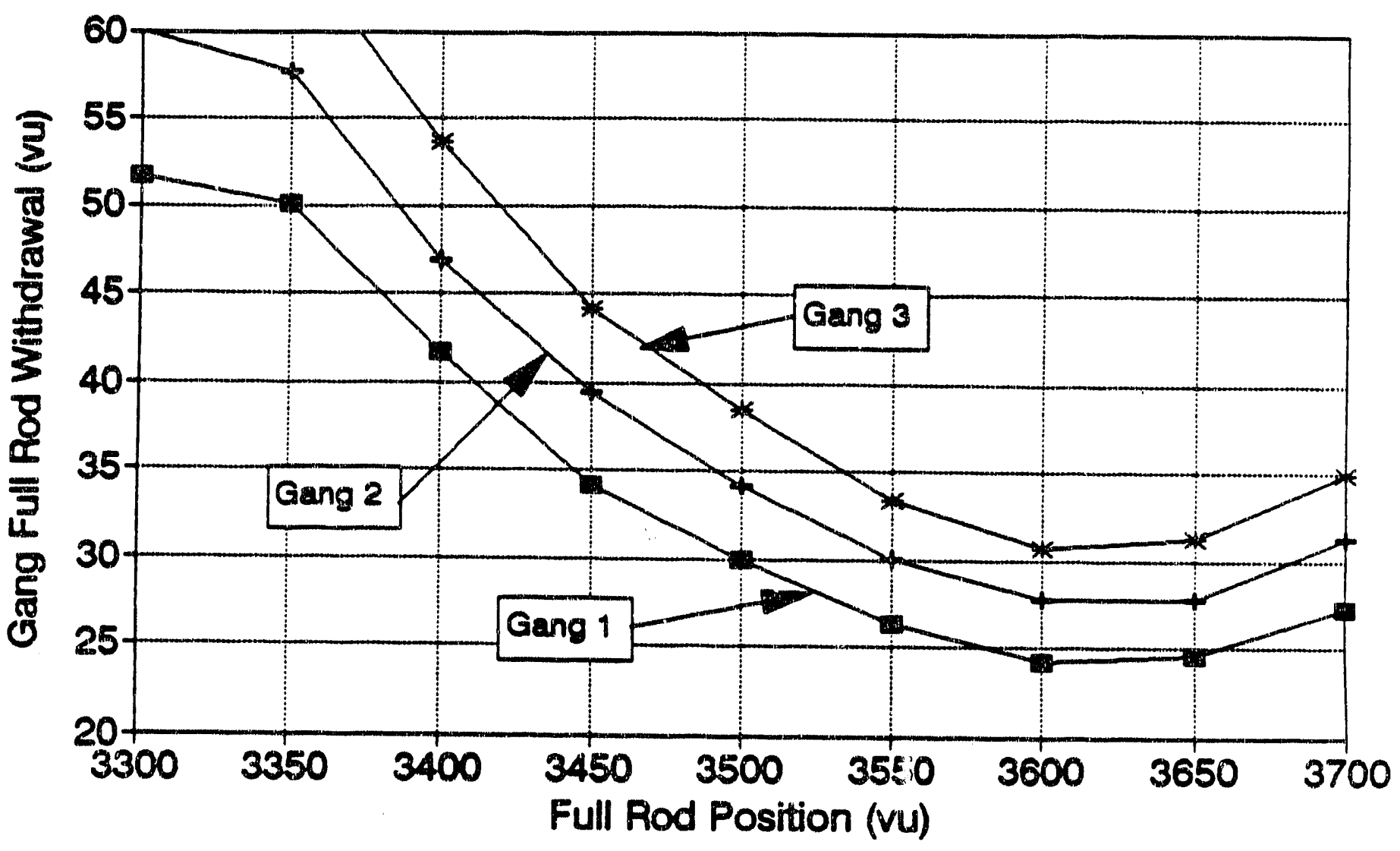


WSRC-TR-91-42-043

Page 68 of 138

June 4, 1991

FIGURE 40

\section{Full Rod Withdrawal - 10 PCM Reactivity Weak Partial Rods at $700 \mathrm{vu}$}

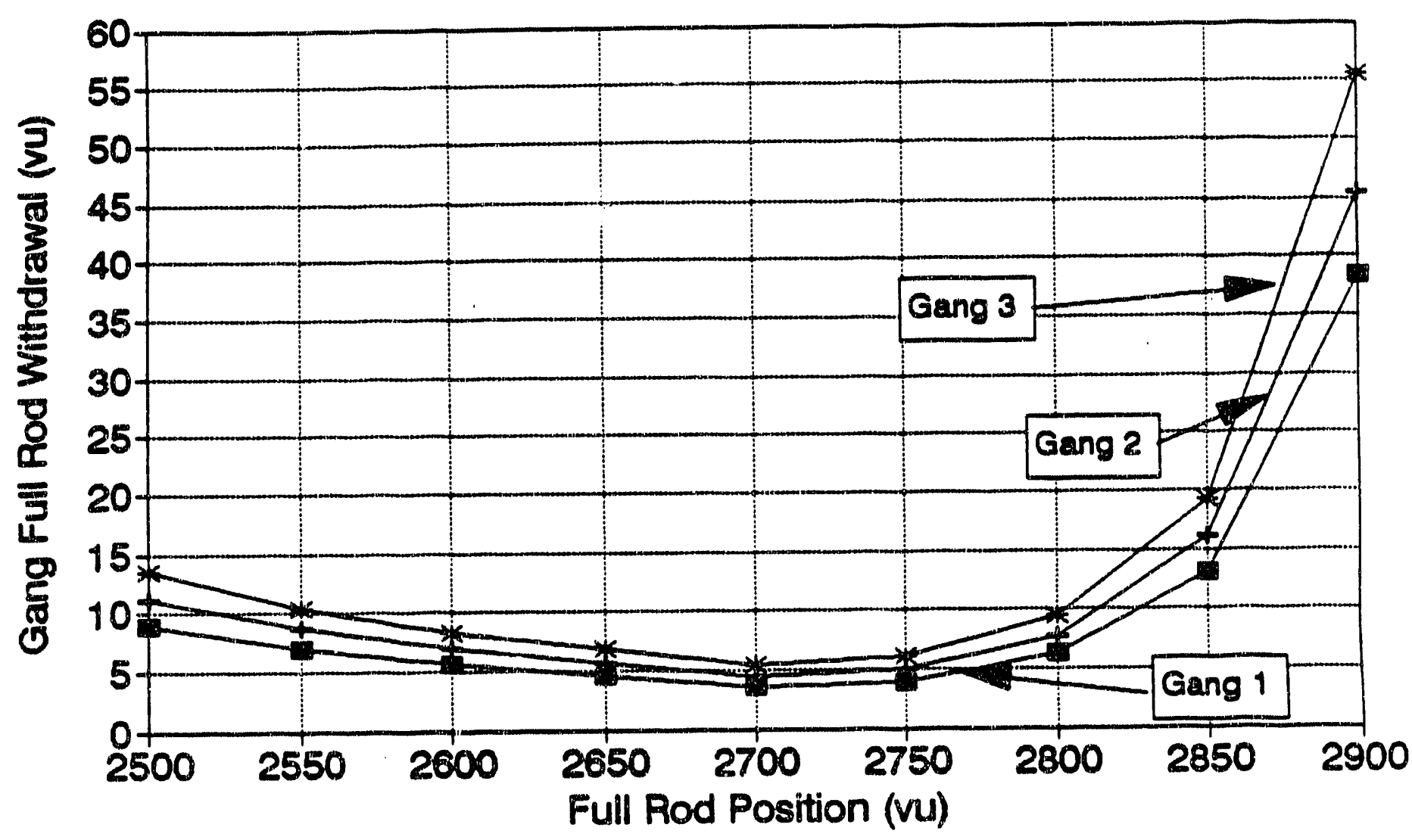


WSRC-TR-91-42-043

Page 69 of 138

June 4, 1891

FIGURE 41

\section{Full Rod Withdrawal - 10 PCM Reactivity Weak Pariial Rods at 700 vu}

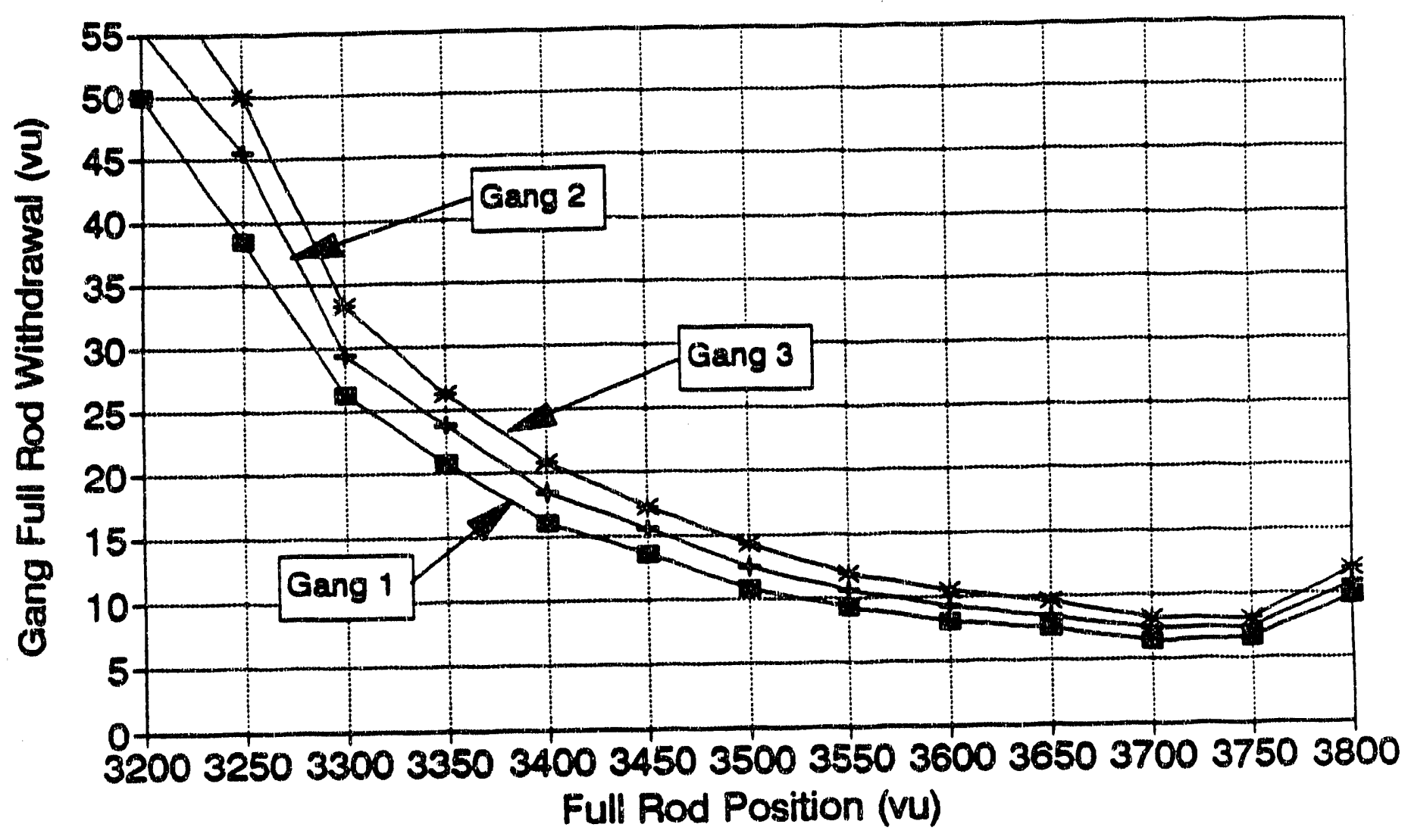


WSRC-TR-91-42-043

Page 70 of 38

June 4, 1991

FIGURE 42

\section{Full Rod Withdrawal - 20 PCM Reactivity Weak Partial Rods at $700 \mathrm{vu}$}

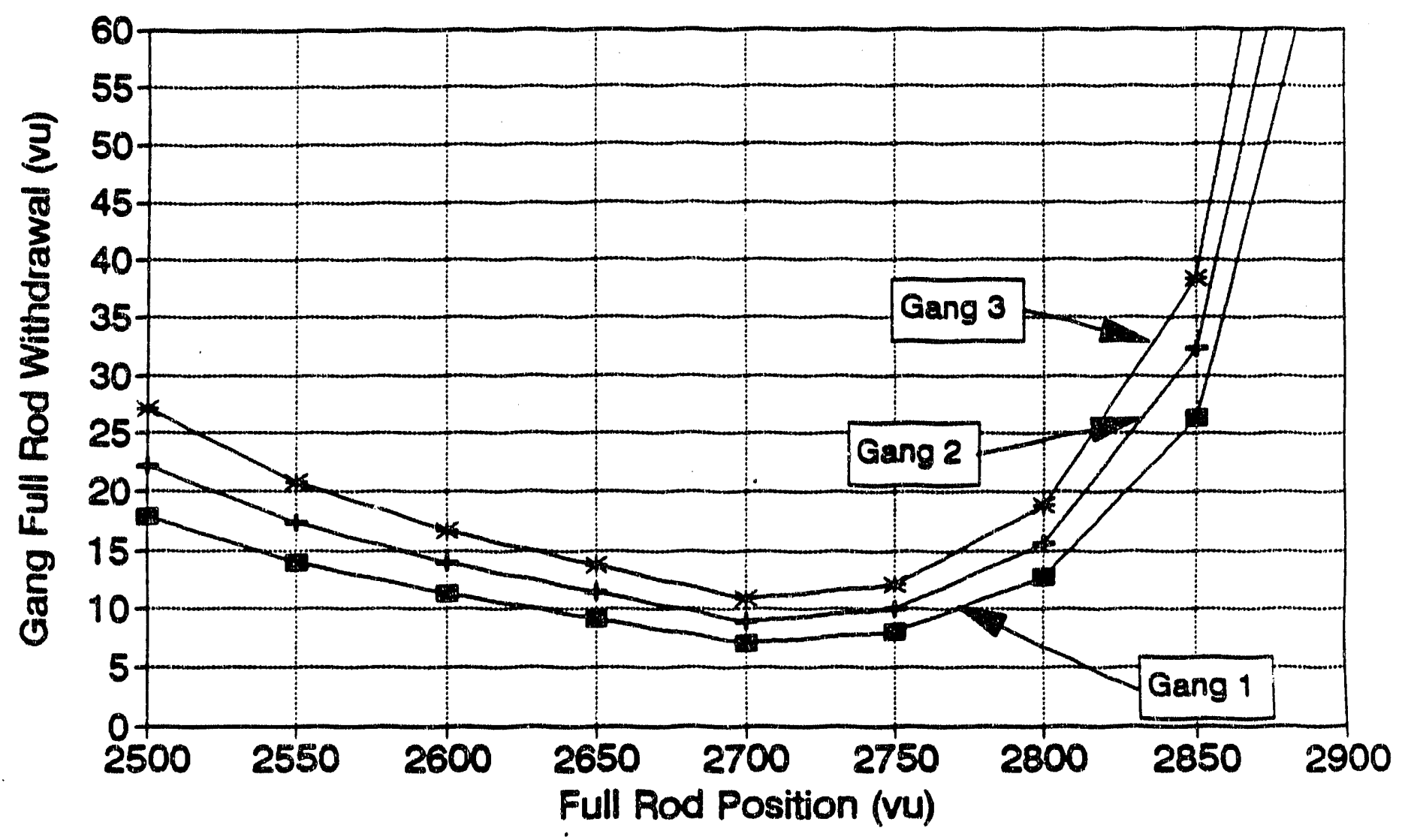


WSAC-TR-91-42-043

Page 71 of 138

June 4, 1991

FIGURE 43

\section{Full Rod Withdrawal - 20 PCM Reactivity Weak Partial Rods at $700 \mathrm{vu}$}

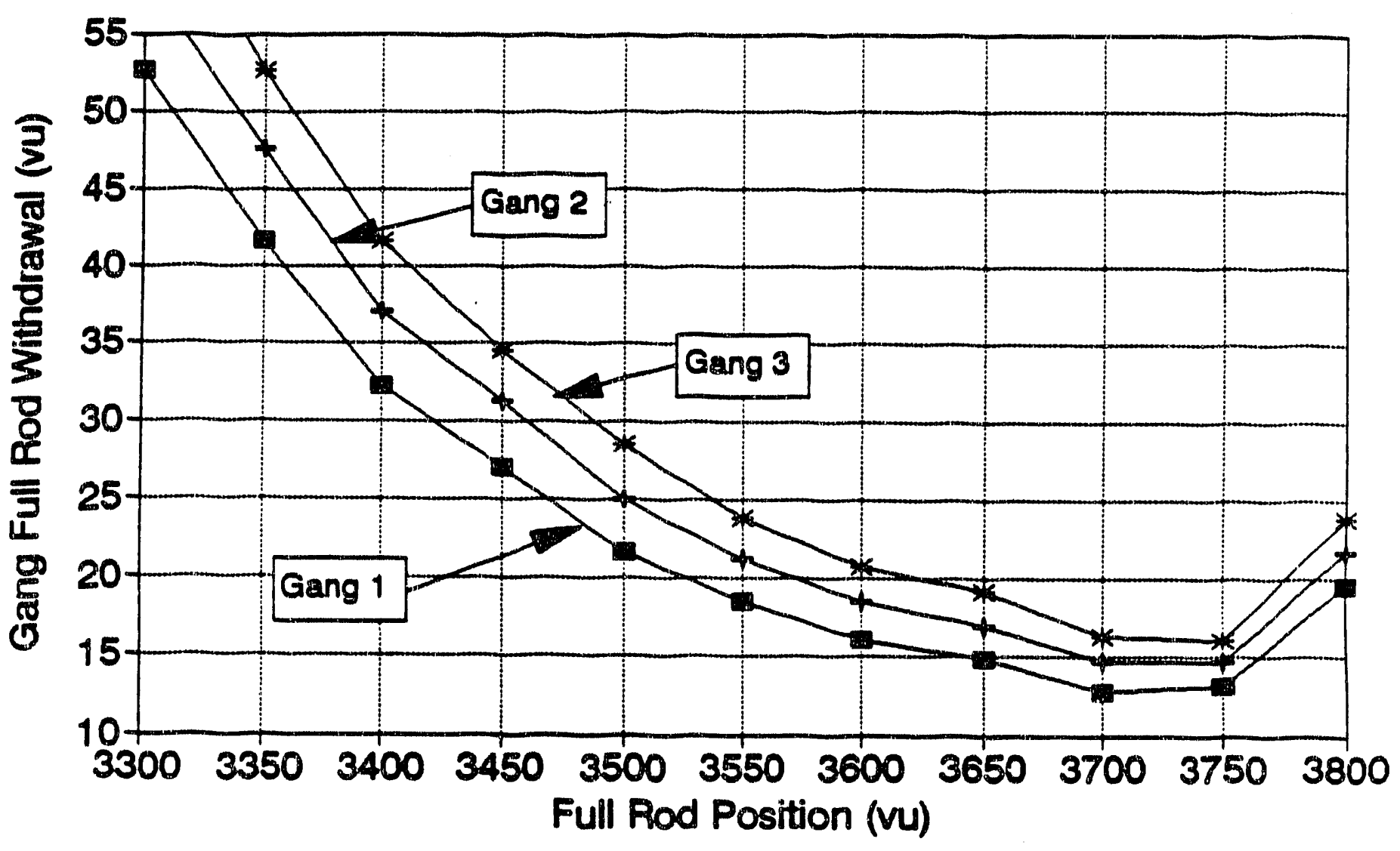


WSRC-TR-91-42-043

Page 72 of 138

June 4, 1991

FIGURE 44

Full Rod Withdrawal - 30 PCM Reactivity Weak Partial Rods at $700 \mathrm{vu}$

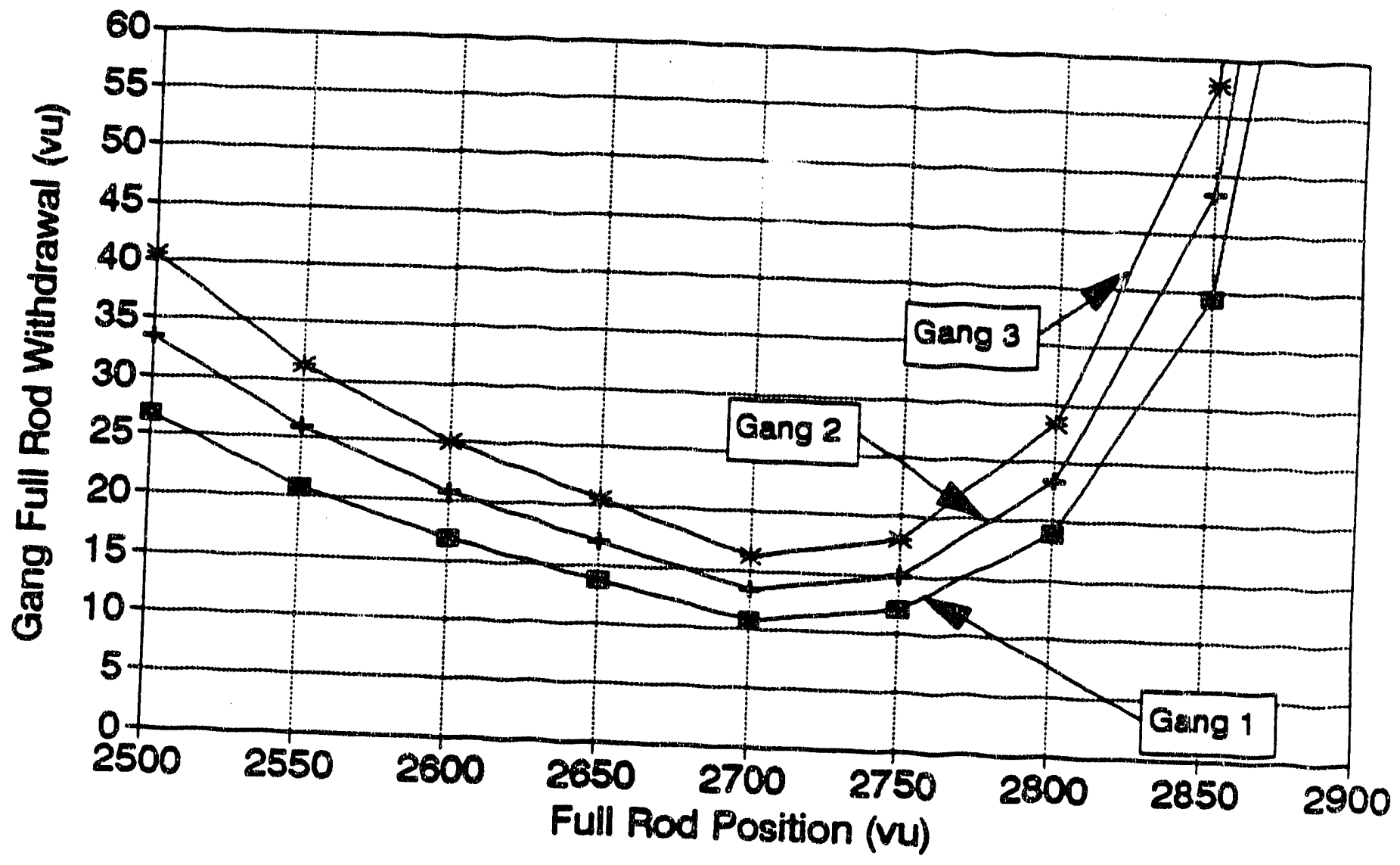


WSRC-TR-91-42-043

Page 73 of 138

June 4, 1991

FIGURE 45

\section{Full Rod Withdrawal - 30 PCM Reactivity Weak Partial Rods at $700 \mathrm{vu}$}

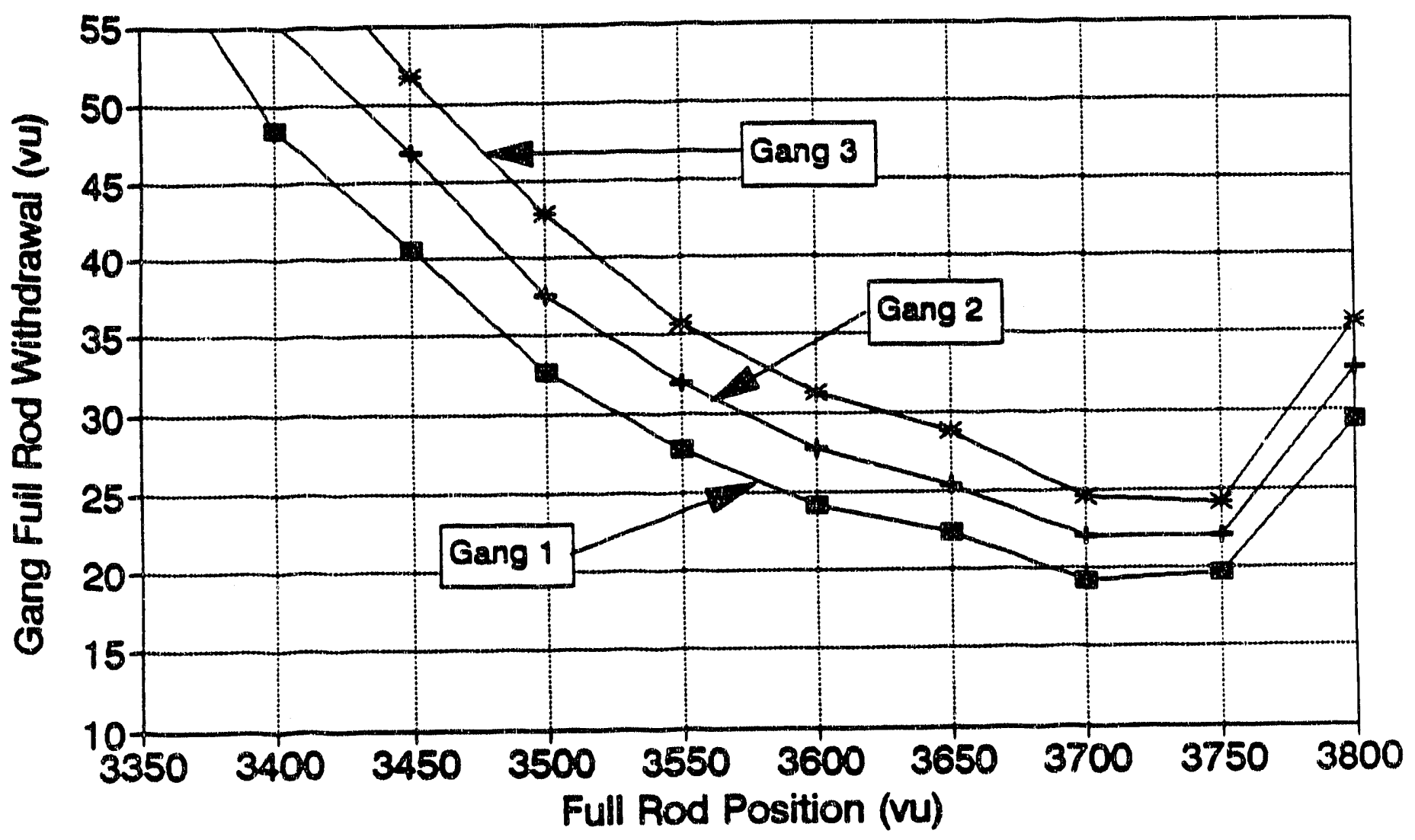


WSRC-TR-91-42-043

Page 74 of 138

June 4, 1991

FIGURE 46

Full Rod Withdrawal - 10 PCM Reactivity Weak Partial Rods at $950 \mathrm{vu}$

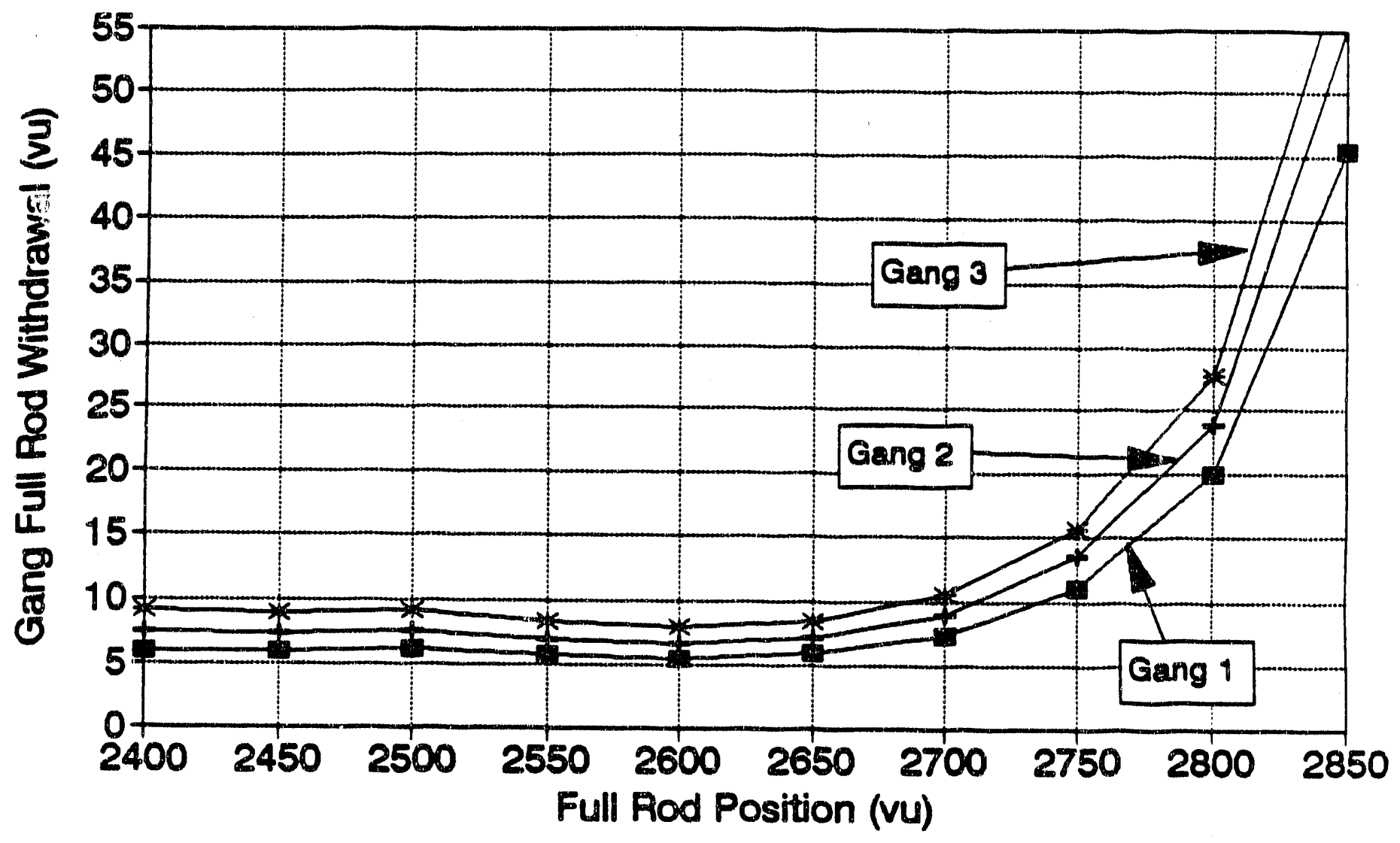


WSRC-TR-91-42-043

Page 75 of 138

June 4, 1991

FIGURE 47

\section{Full Rod Withdrawal - 10 PCM Reactivity Weak Partial Rods at $950 \mathrm{vu}$}

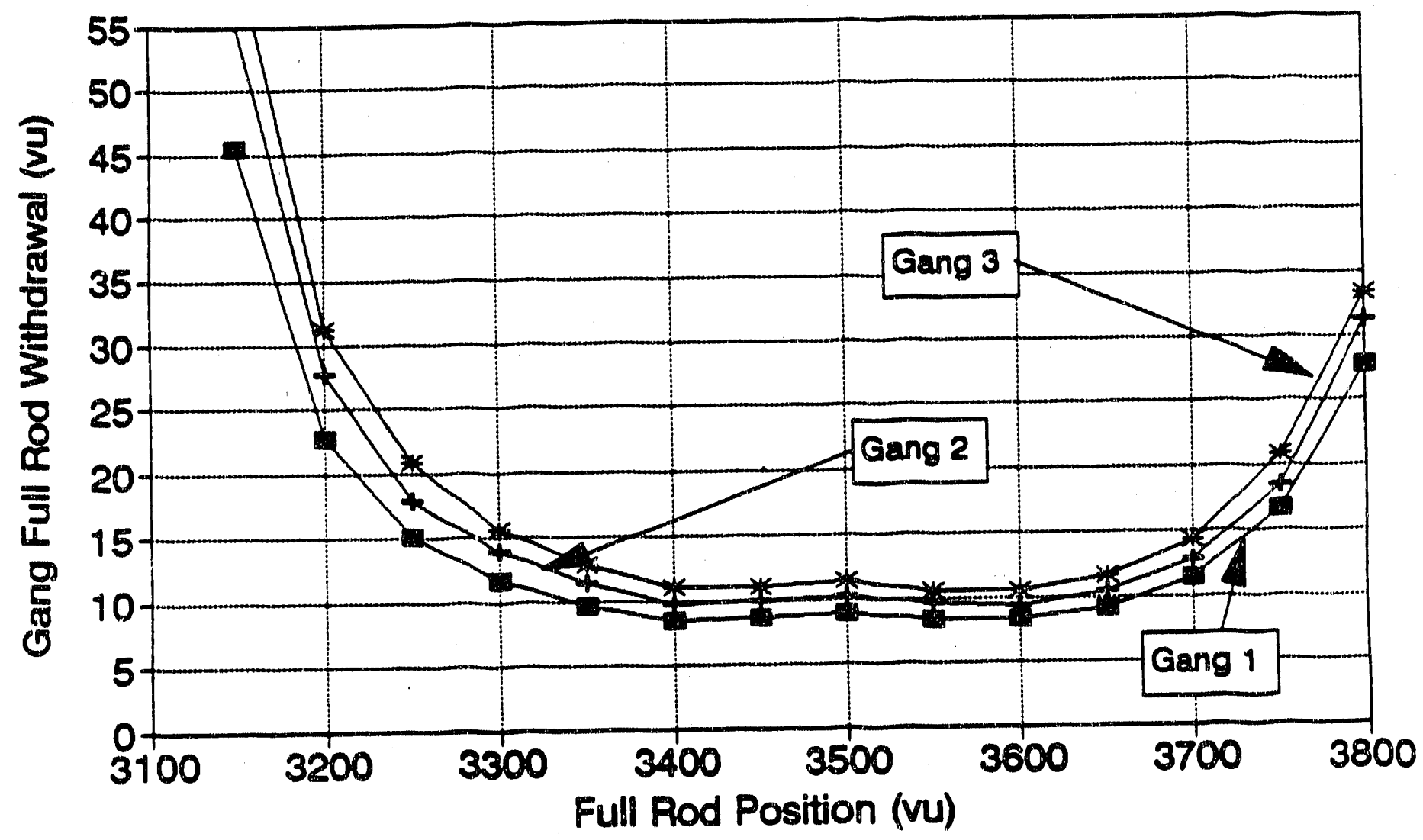


WSRC-TR-91-42-043

Page 76 of 138

June 4, 1991

FIGURE 48

\section{Full Rod Withdrawal - 20 PCM Reactivity Weak Partial Rods at $950 \mathrm{vu}$}

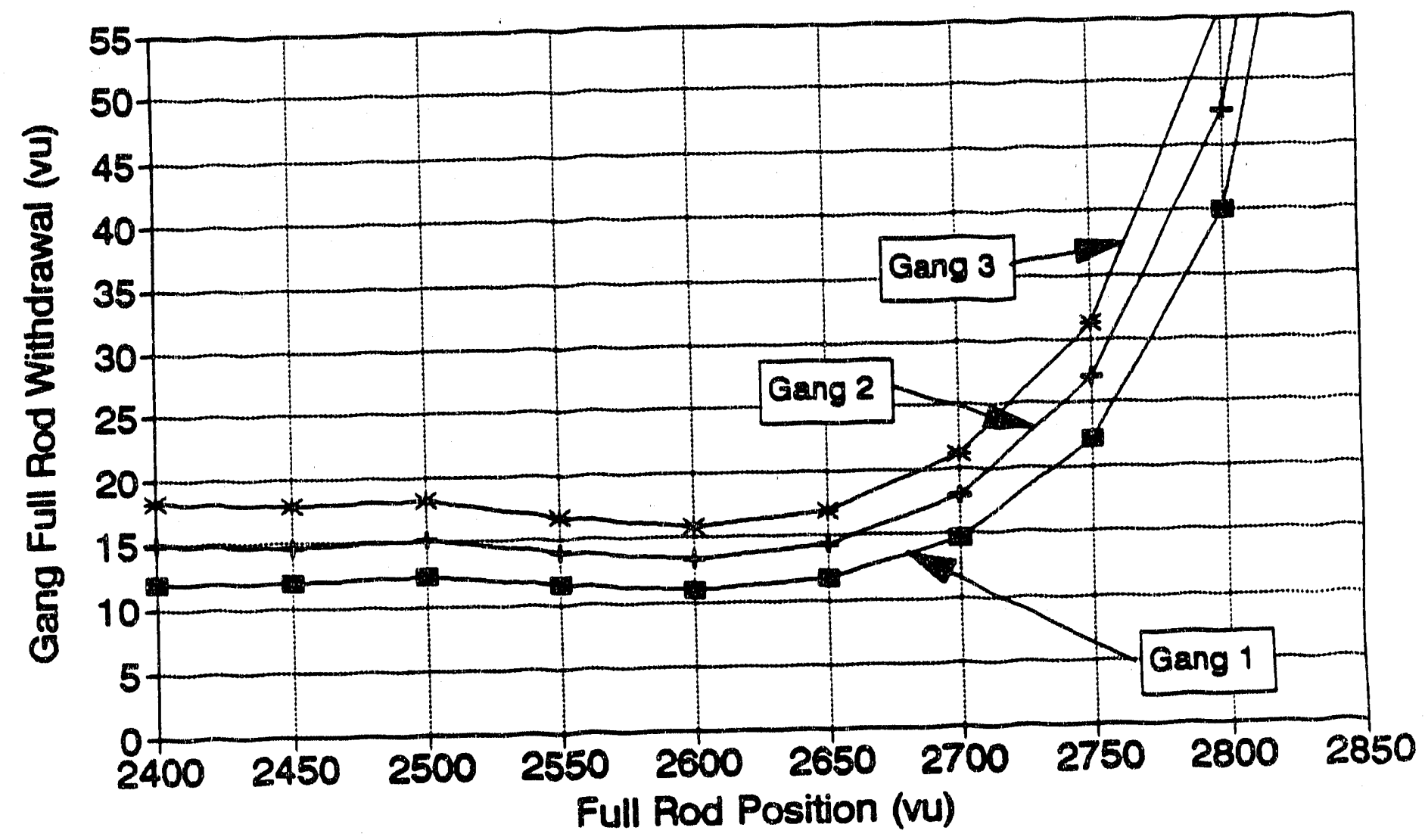


WSRC-TR-91-42-043

Page 77 of 138

June 4, 1991

FIGURE 49

Full Rod Withdrawal - 20 PCM Reactivity
Weak Partial Rods at 950 vu

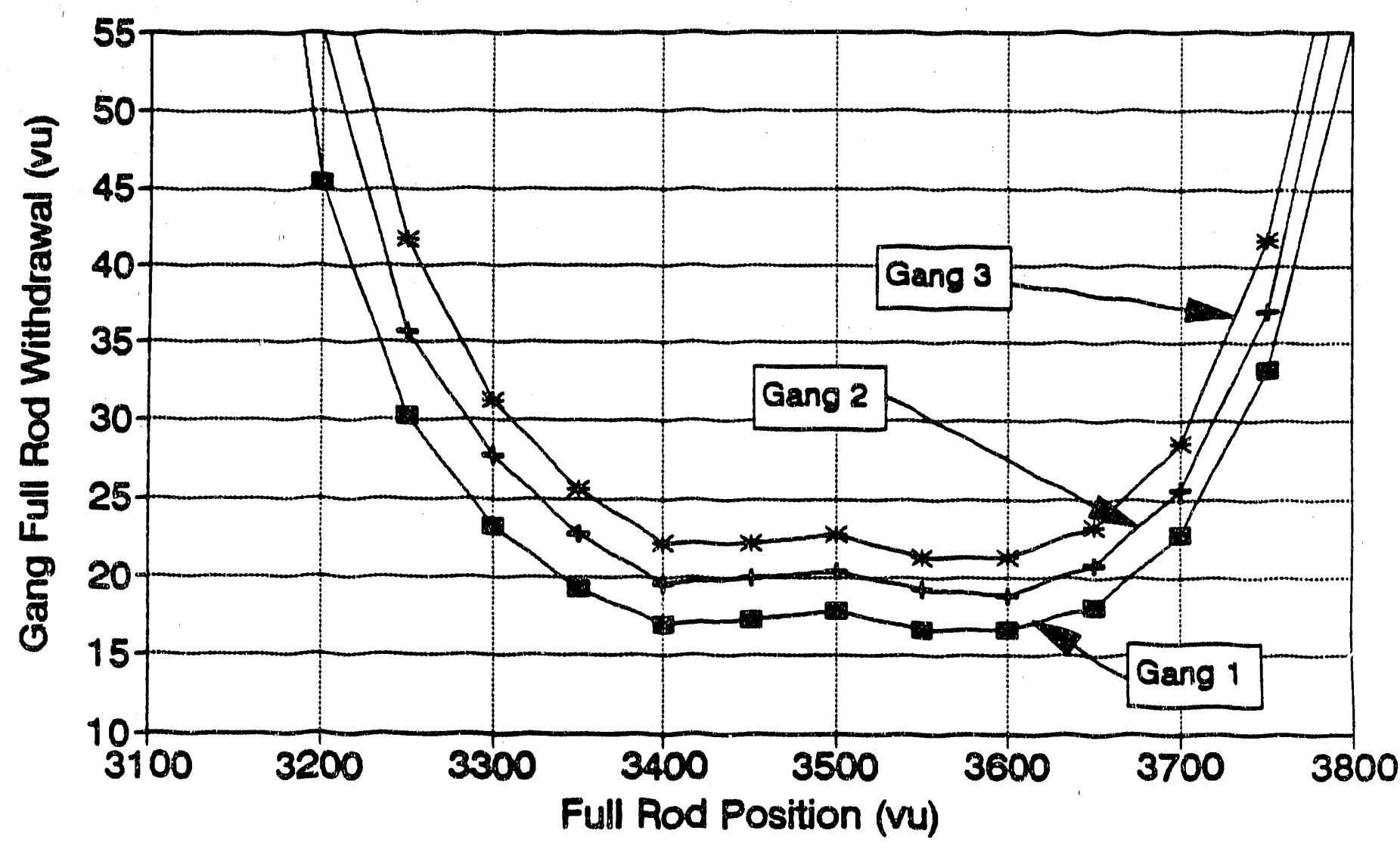


WSRC-TR-91-42-043

Page 78 of 138

June 4, 1991

FIGURE 50

\section{Full Rod Withdrawal - 30 PCM Reactivity Weak Partial Rods at $950 \mathrm{vu}$}

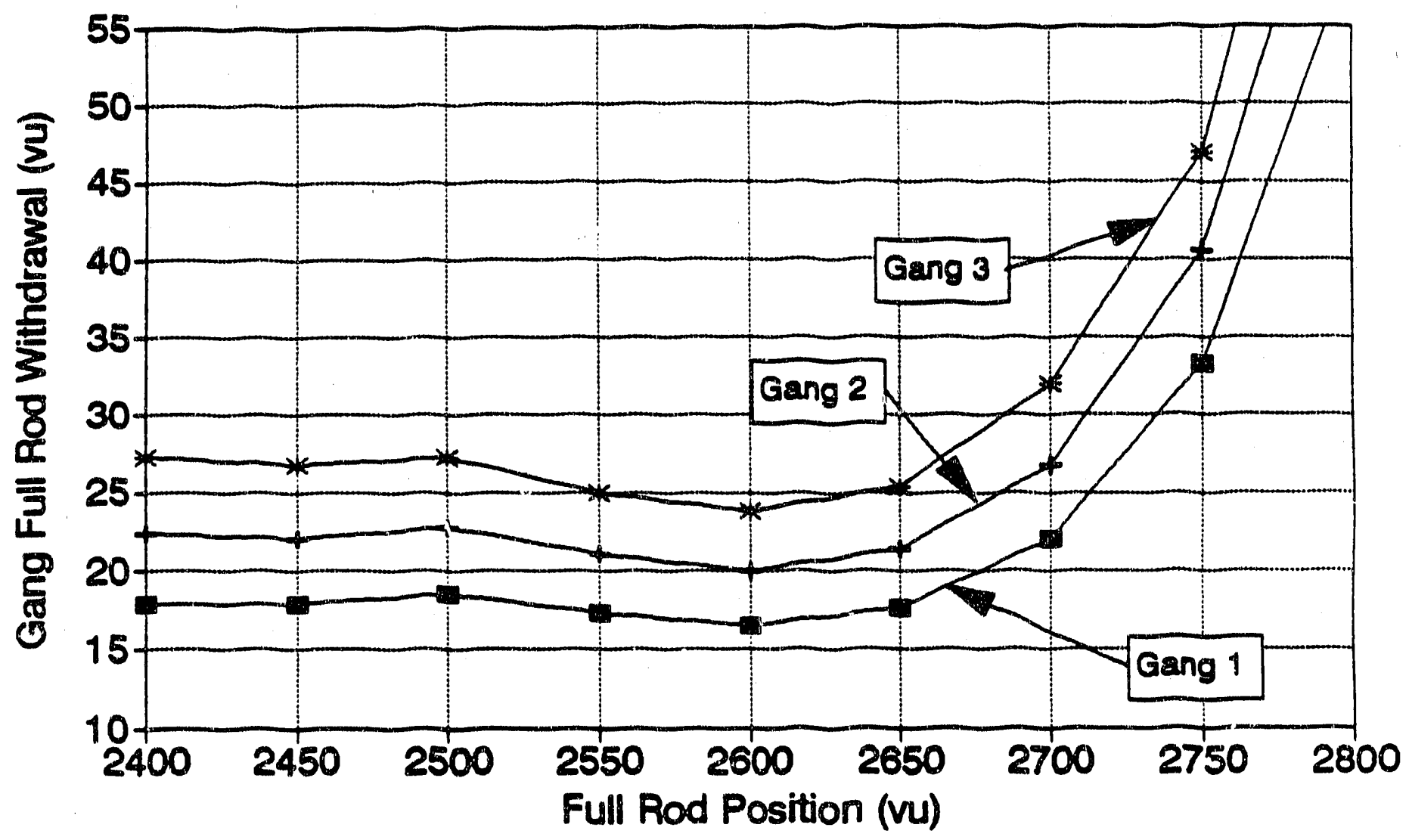


WSRC-TR-91-42-043

Page 79 of 138

June 4, 1991

FIGURE 51

\section{Full Rod Withdrawal - 30 PCM Reactivity Weak Partial Rods at $950 \mathrm{vu}$}

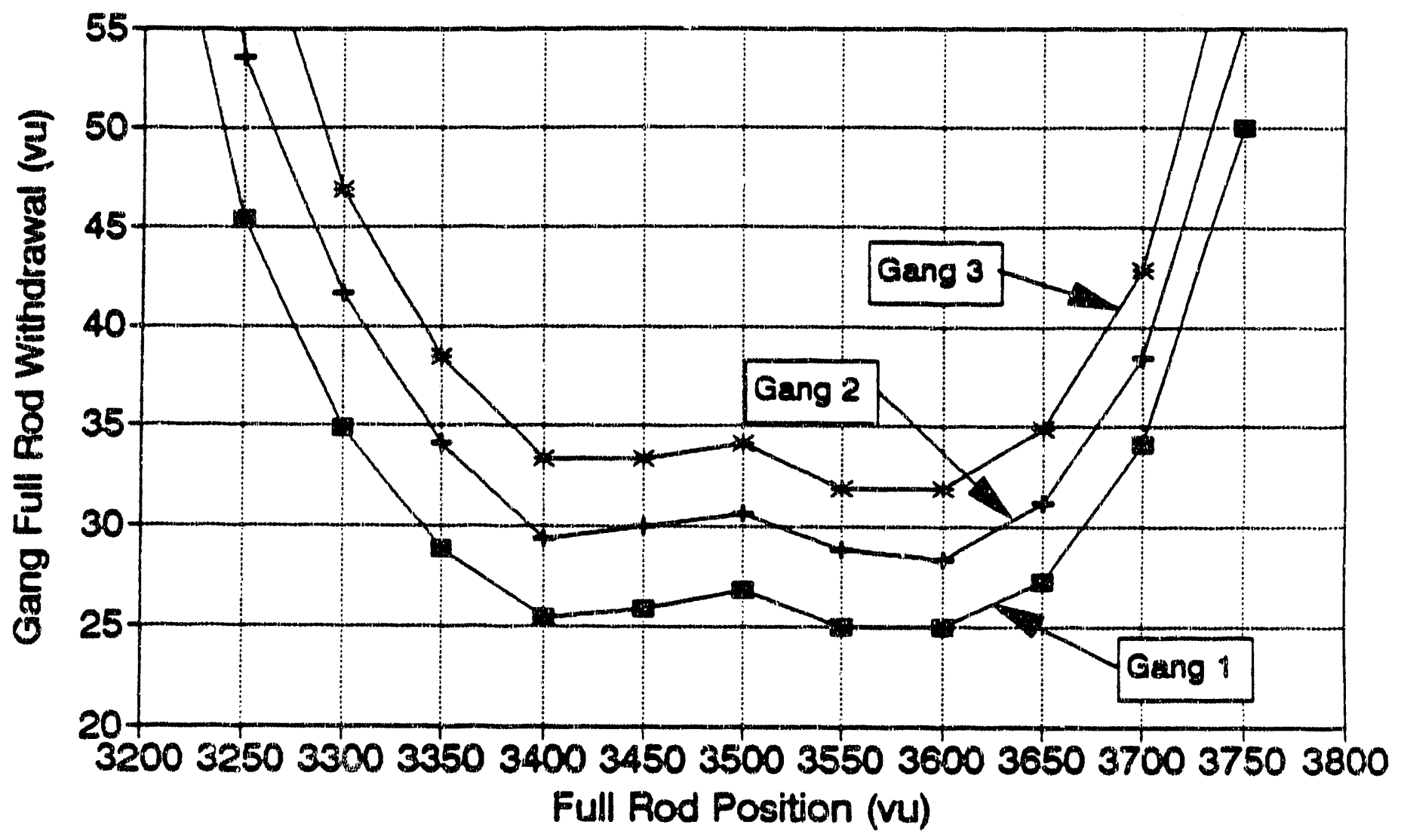


WSRC-TR-91-42-043

Page 80 of 138

June 4, 1991

FIGUSRE 52

\section{REACTIVITY WORTH - CLUSTER 1 STRONG PARTIAL ROD 800 VU TO 1000 VU}

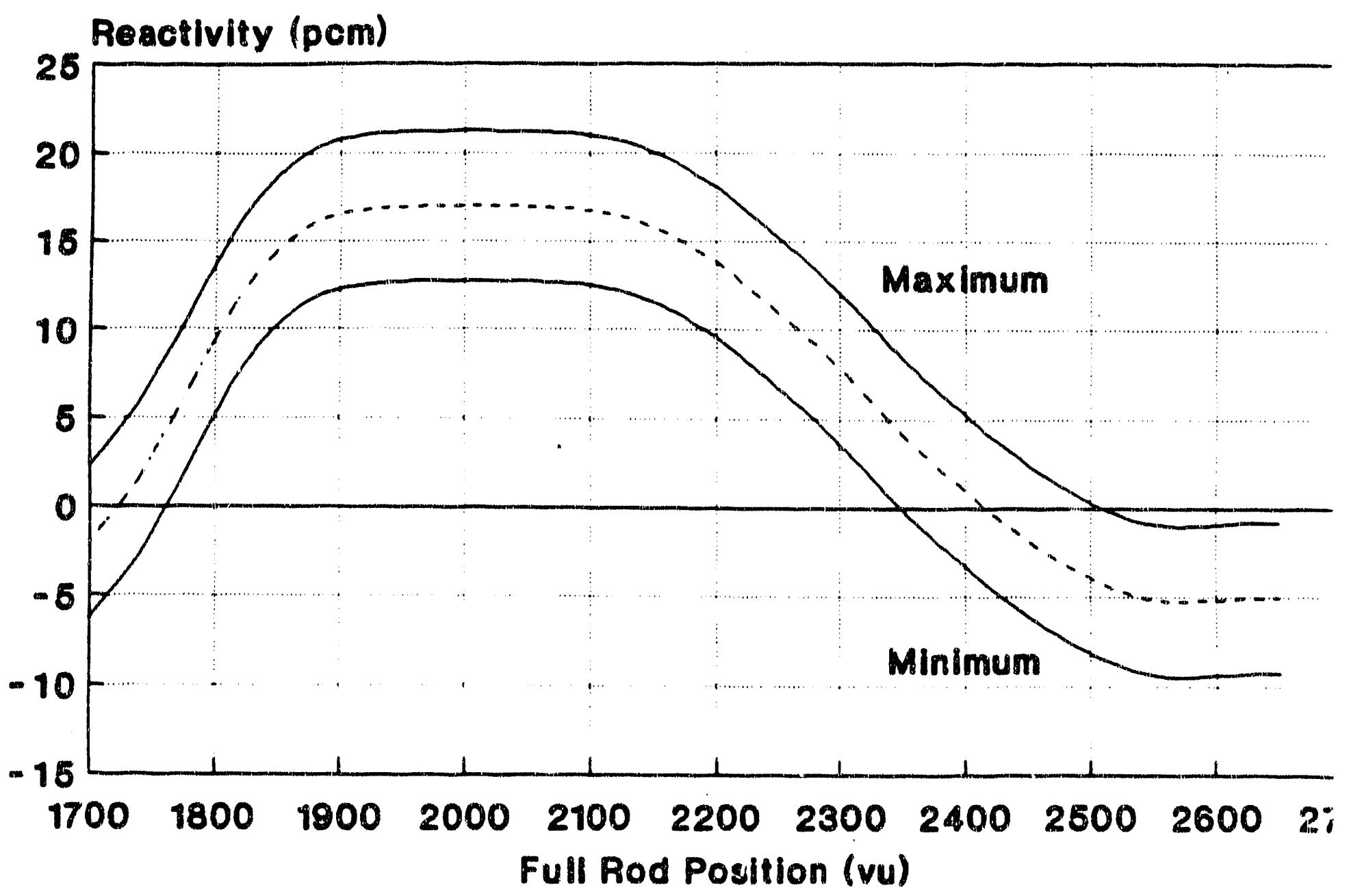


WSRC-TR-91-42-043

Page 81 of 138

June 4, 1991

FIGURE 53

\section{REACTIVITYY WORTH - CLUSTER 36 STRONG PARTIAL ROD 800 VU TO 1000 VU}

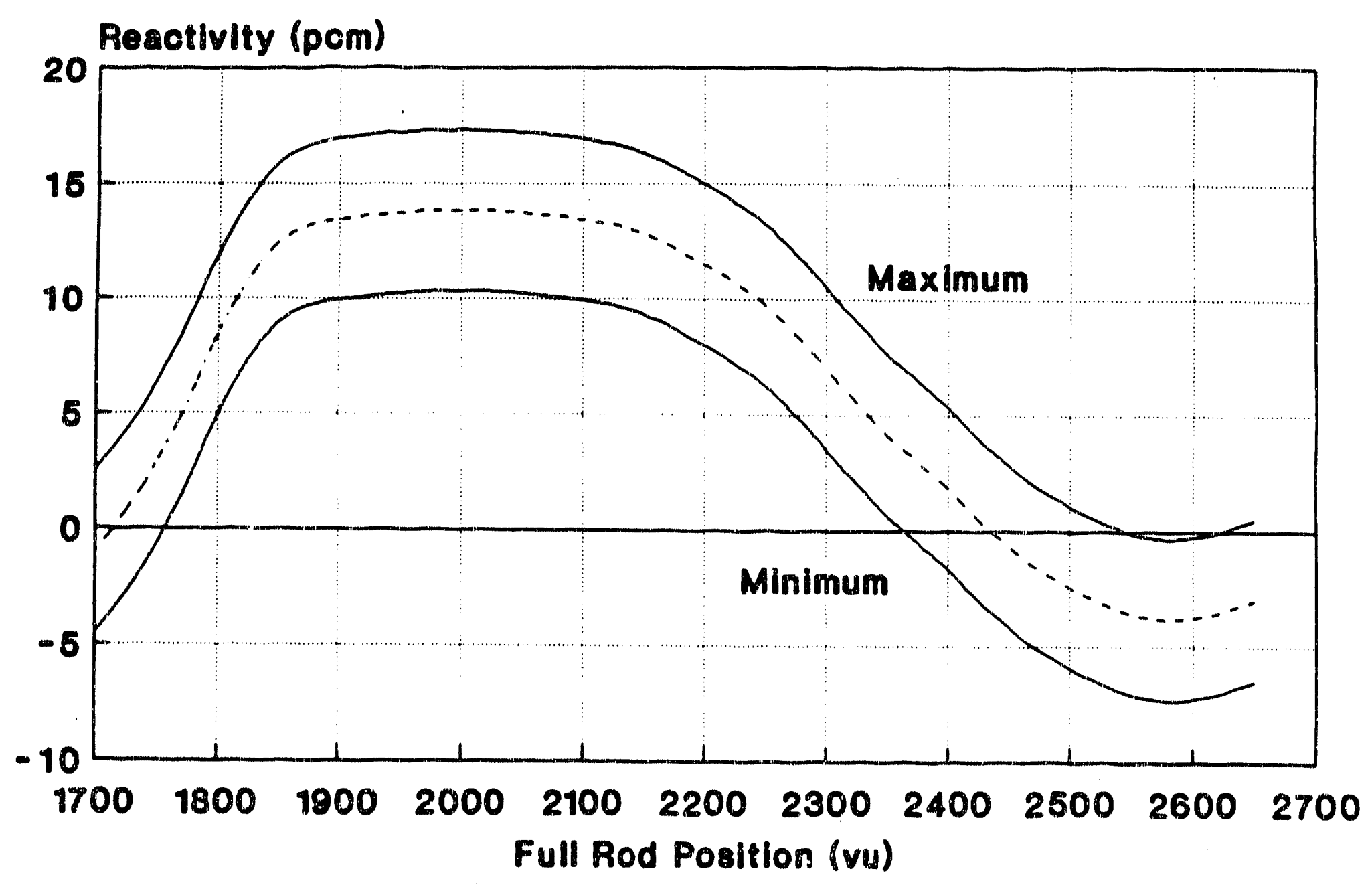


WSRC-TR-91-42-043

Page 82 of 138

June 4, 1991

FIGURE 54

\section{REACTIVITYY WORTH - CLUSTER 52 STRONG PARTIAL ROD $800 \mathrm{VU}$ TO $1000 \mathrm{VI}$}
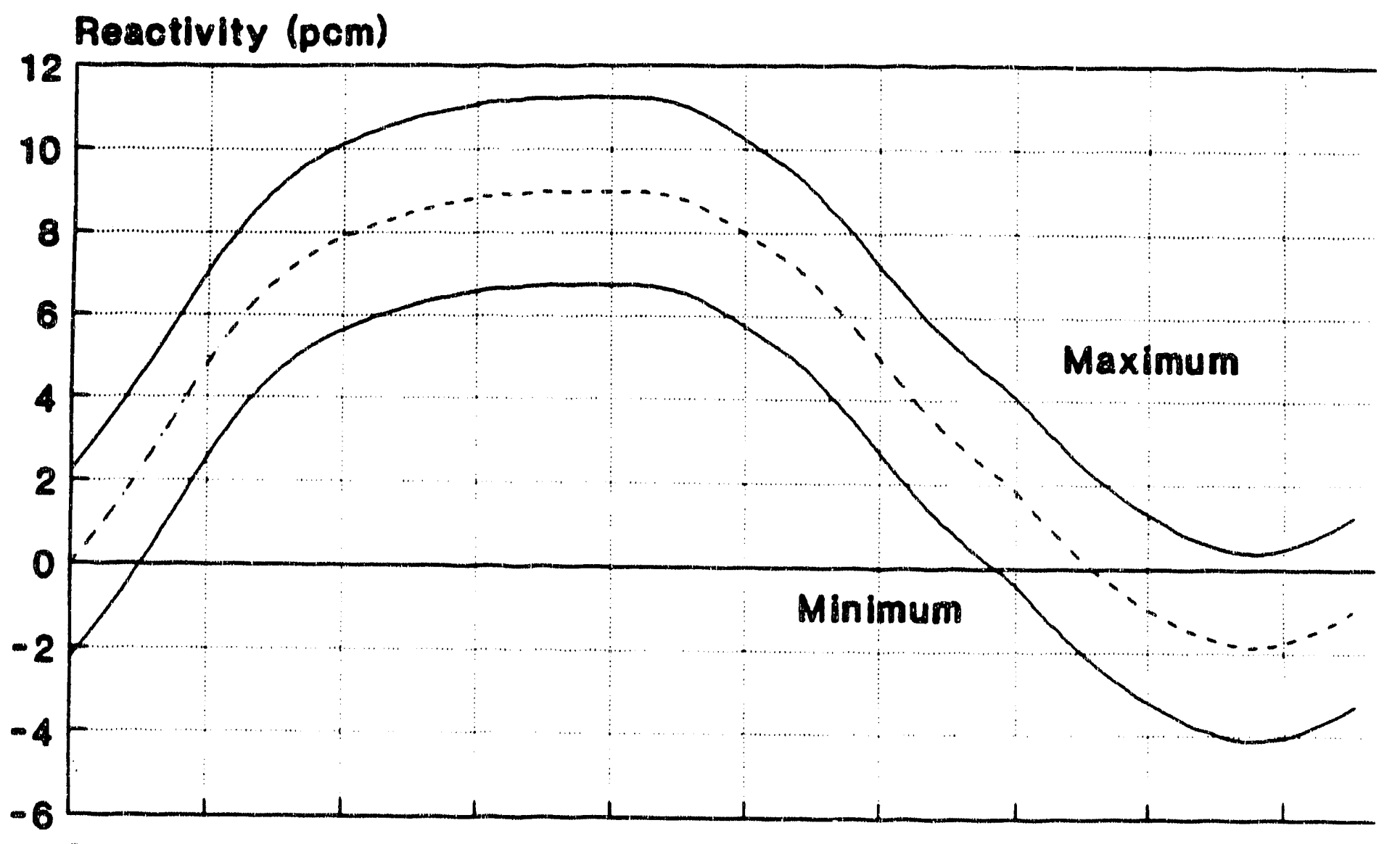

$\begin{array}{llllllllll}1700 & 1800 & 1900 & 2000 & 2100 & 2200 & 2300 & 2400 & 2500 & 2600\end{array}$ Full Rod Positlon (vu) 
WSRC-TR-91-42-043

Page 83 of 138

June 4, 1991

FIGURE 55

\section{REACTIVITYY WORTH - CLUSTER 1 WEAK PARTIAL ROD 800 VU TO 1000 VU}

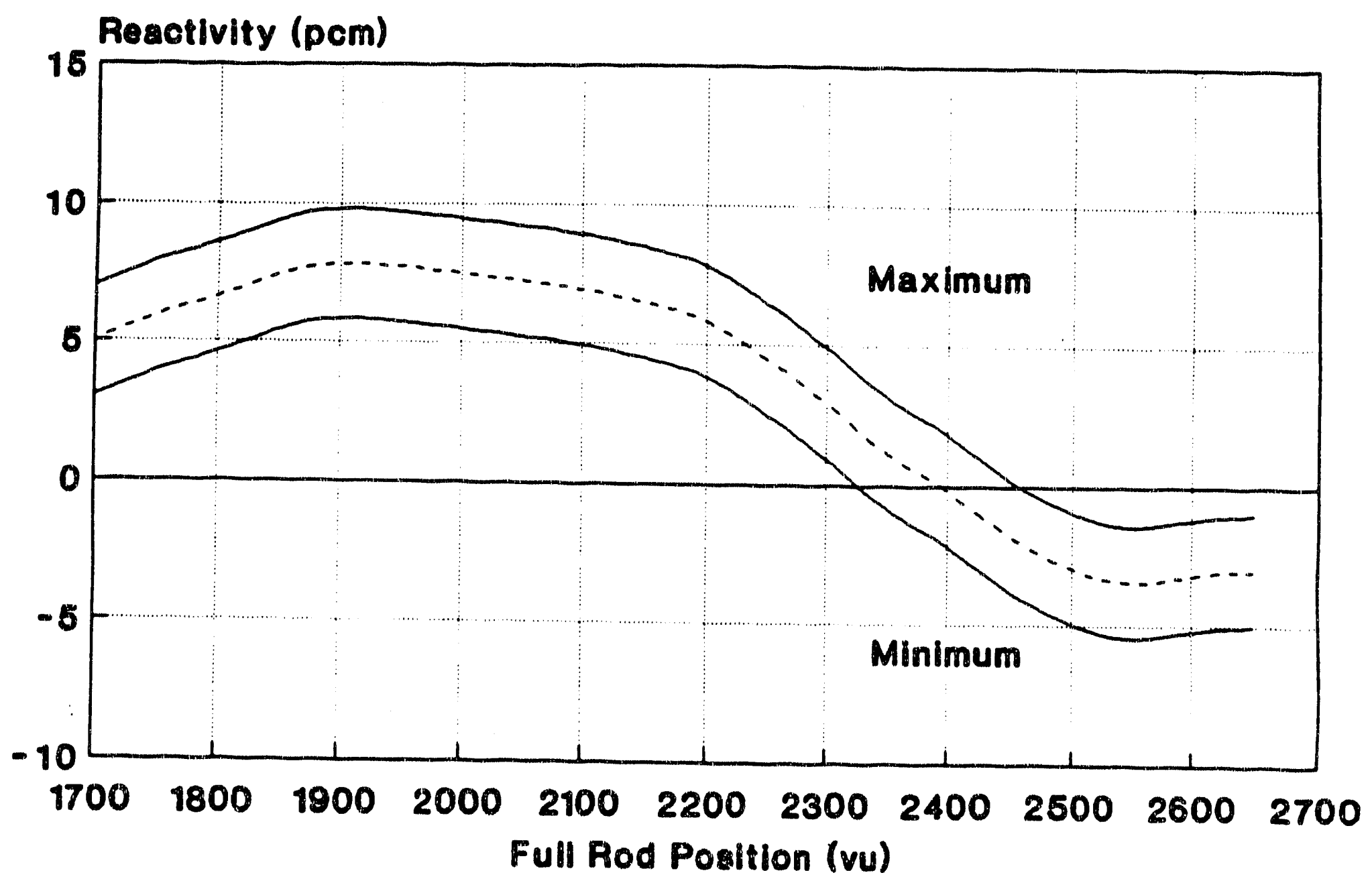


WSRC-TR-91-42-043

Page 84 of 138

June 4, 1901

FIGURE 56

\section{REACTIVITY WORTH - CLUSTER 36 WEAK PARTIAL ROD 800 VU TO 1000 VU}

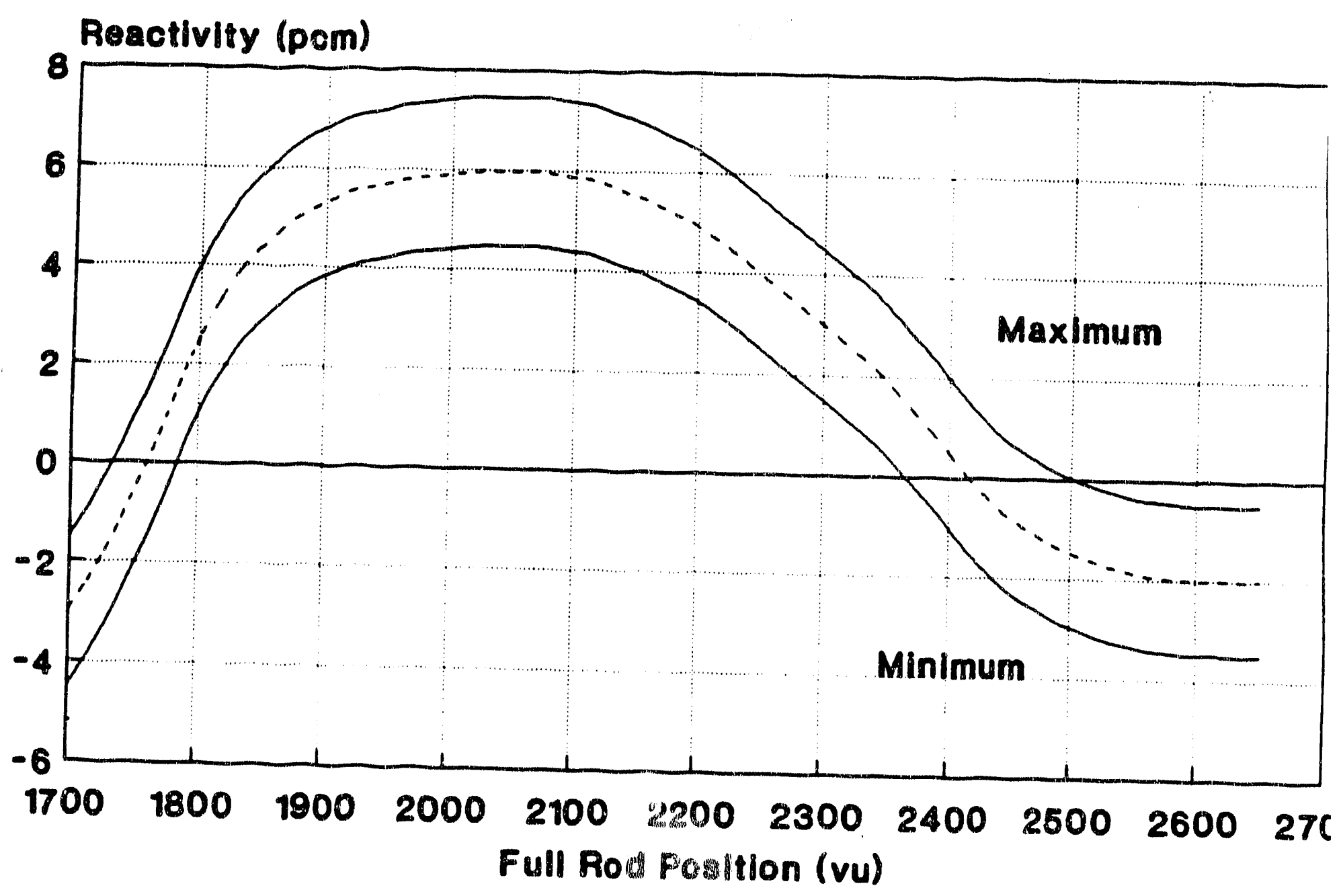


WSRC-TR-91-42-043

Page 85 of 138

June 4, 1991

FIGURE 57

\section{REACTIVITY் WORTH - CLUSTER 52 WEAK PARTIAL ROD 800 VU TO 1000 VU}

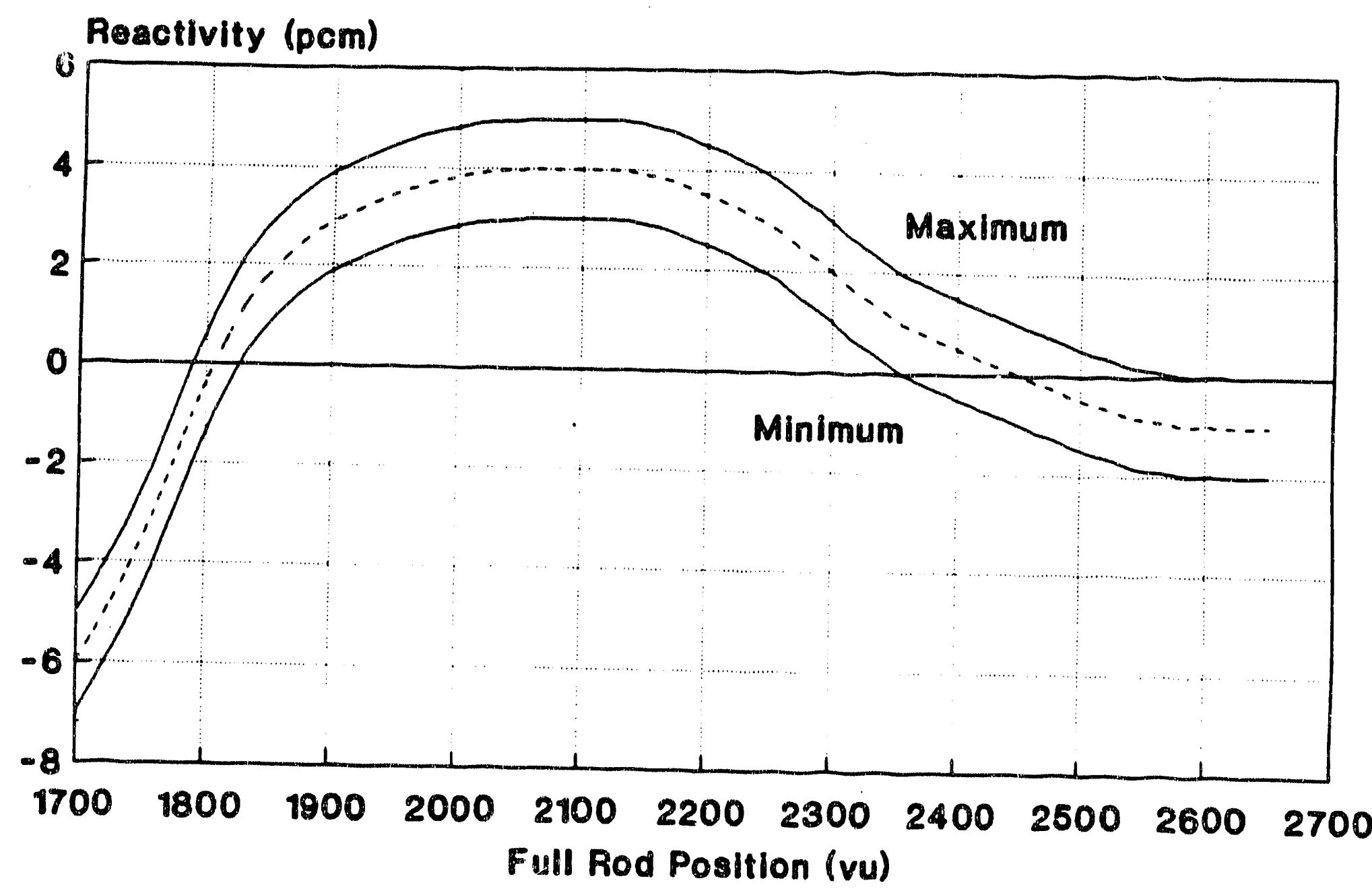


WSRC-TR-91-42-043

Page 86 of 138

June 4, 1991

FIGURE 58

\section{Reactivity Held in Temperature For Zero Reactor Exposure (0 - $800 \mathrm{MW})$}

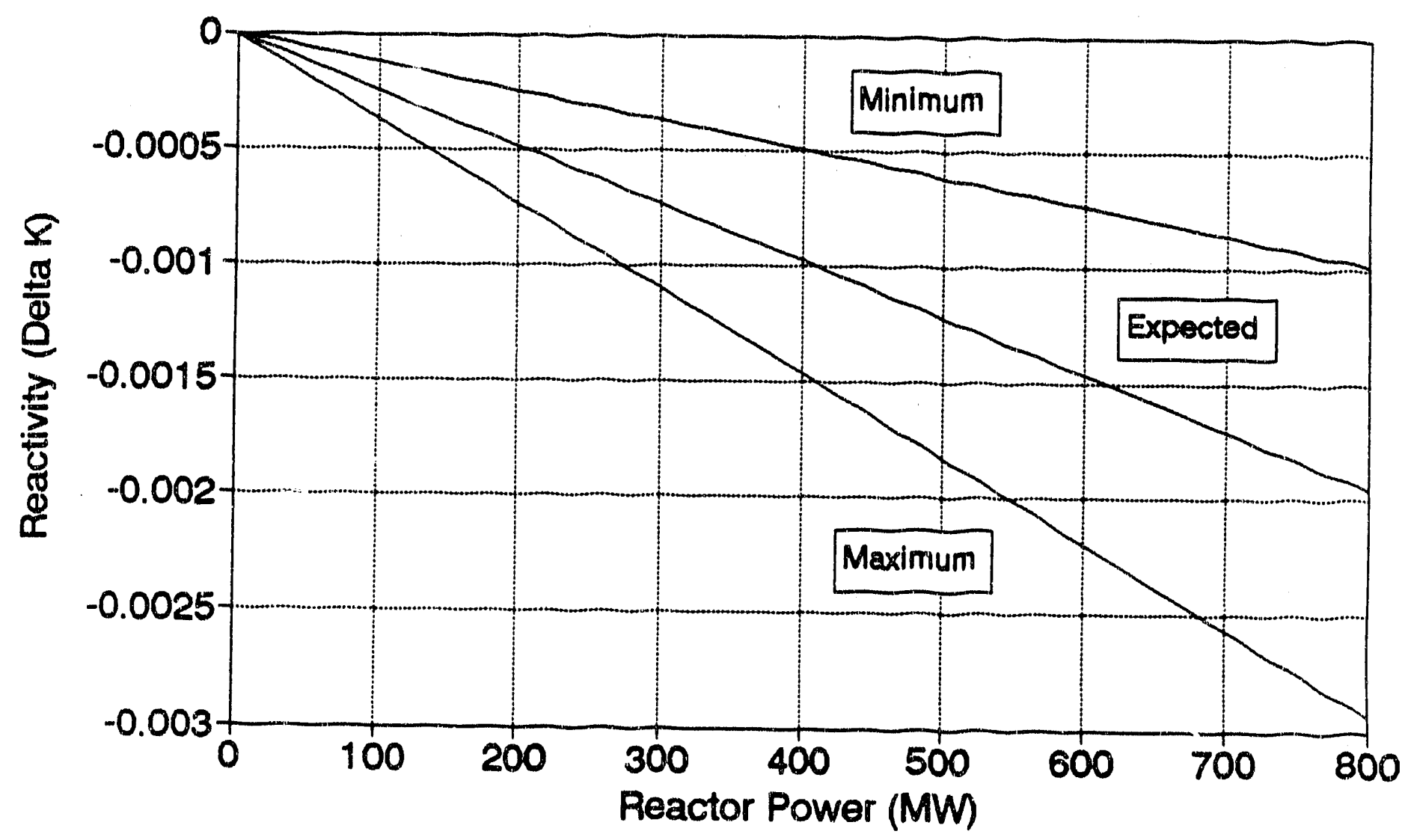


WSRC-TR-91-42-043

Page 87 of 138

June 4, 1991

FIGURE 59

\section{Reactivity Held in Temperature For Zero Reactor Exposure (800 - 1600 MW)}

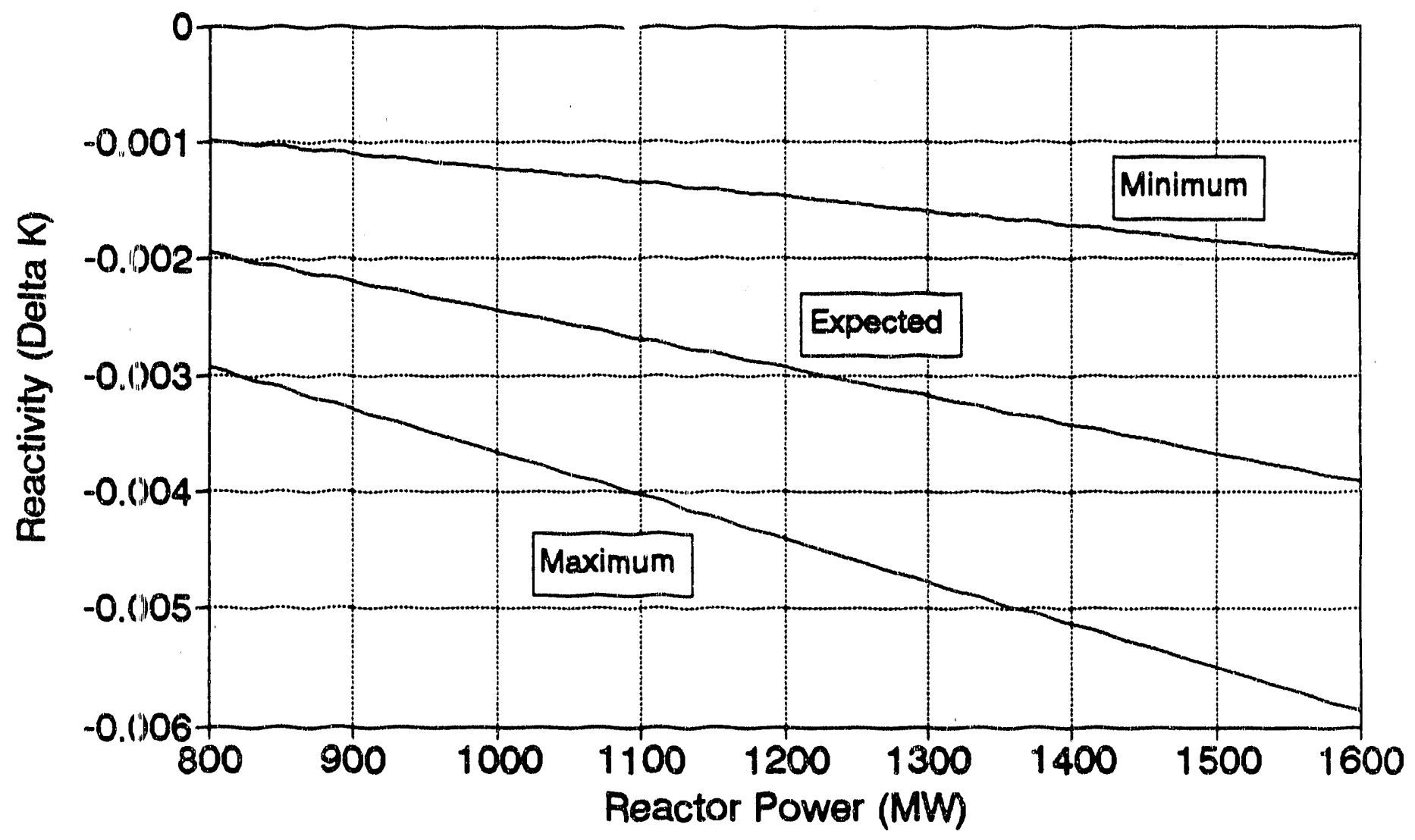


WSRC-TR-91-42-043

Page 89 of 138

June 4, 1991

FIGURE 61

\section{Cluster 20 Strong Li Integral Rod Insertion at $60 \%$ Power}

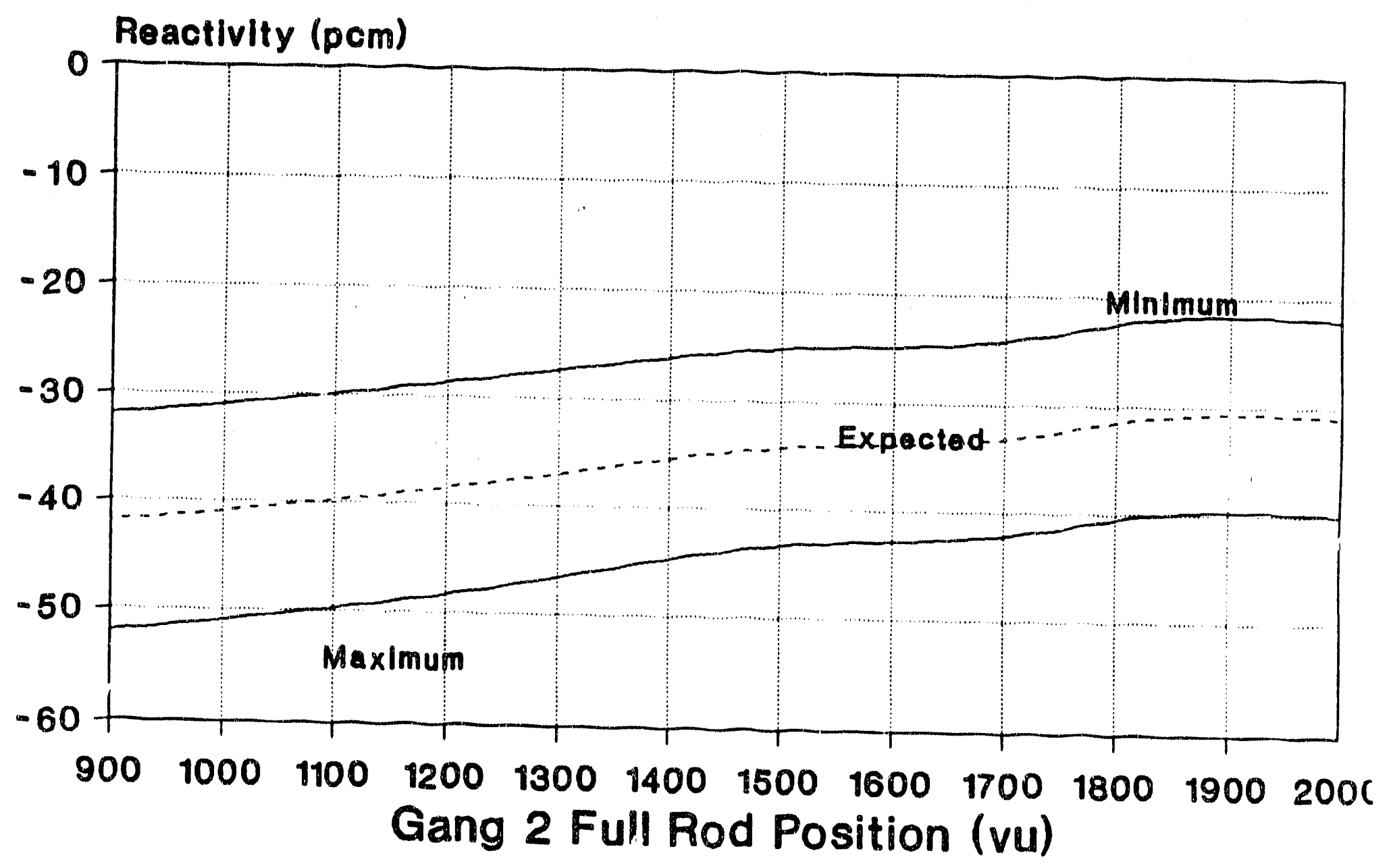


WSRC-TR-91-42-043

Page 88 of 138

June 4, 1991

FIGURE 60

\section{Cluster 3 Strong Li Integral Rod Insertion at $60 \%$ Power}

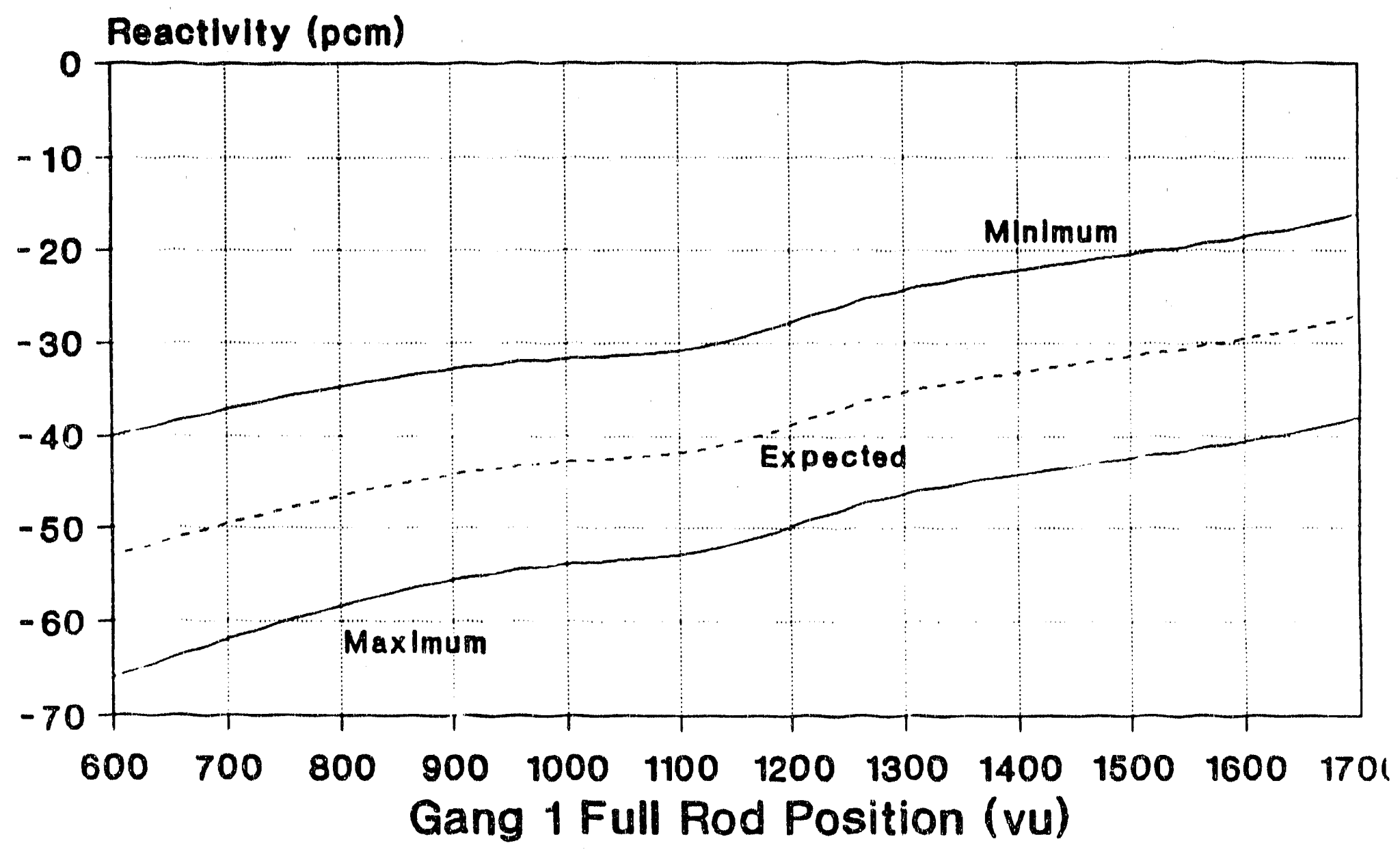


WSRC-TR-91-42-043

Page 90 of 138

June 4, 1991

FIGURE 62

\section{Cluster 54 Strong Li Integral Rod Insertion at $60 \%$ Power}

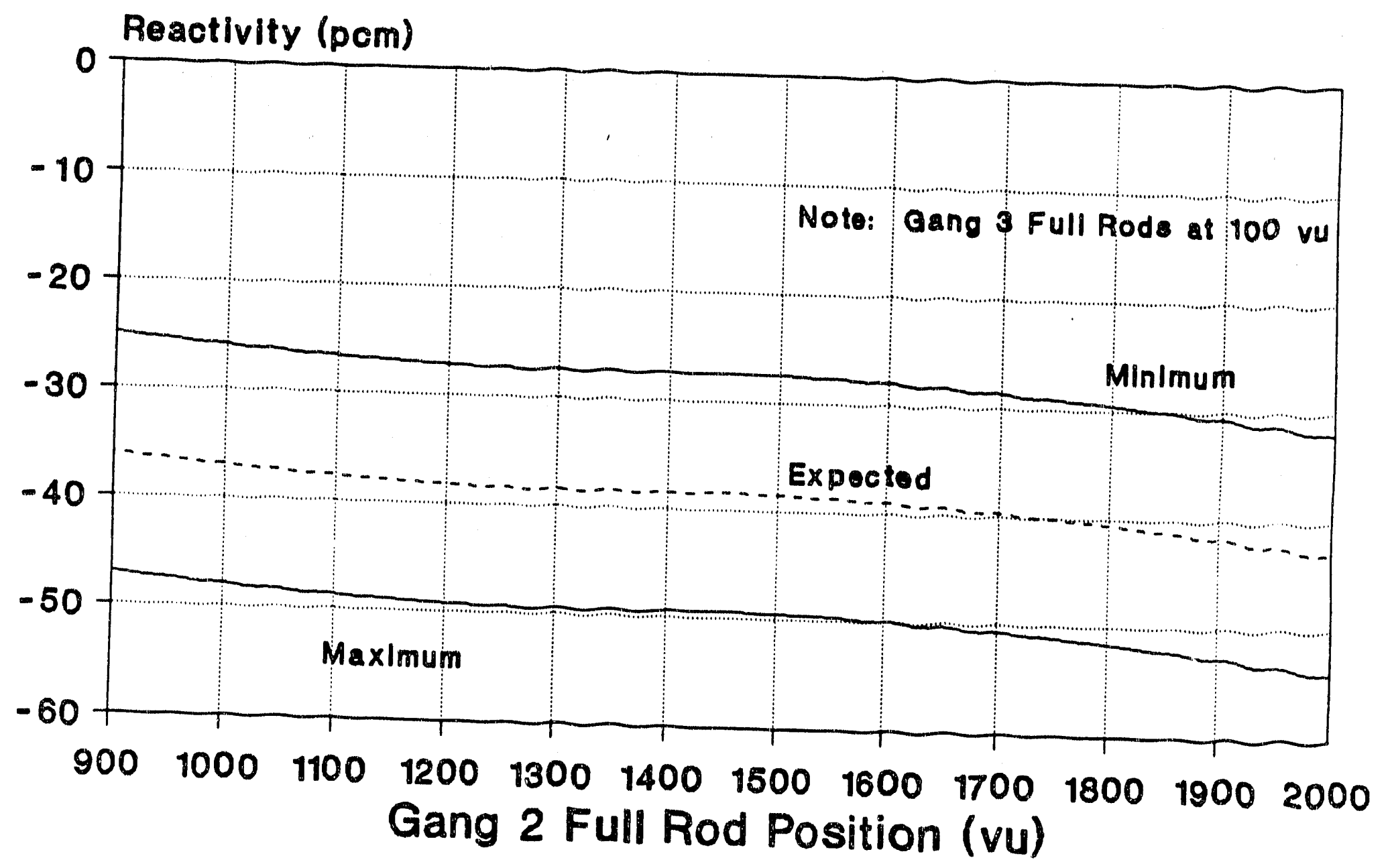


WSRC-TR-91-42-043

Page 91 of 138

June 4, 1991

FIGURE 63

\section{Cluster 54 Strong Li Integral Rod Insertion at $60 \%$ Power}

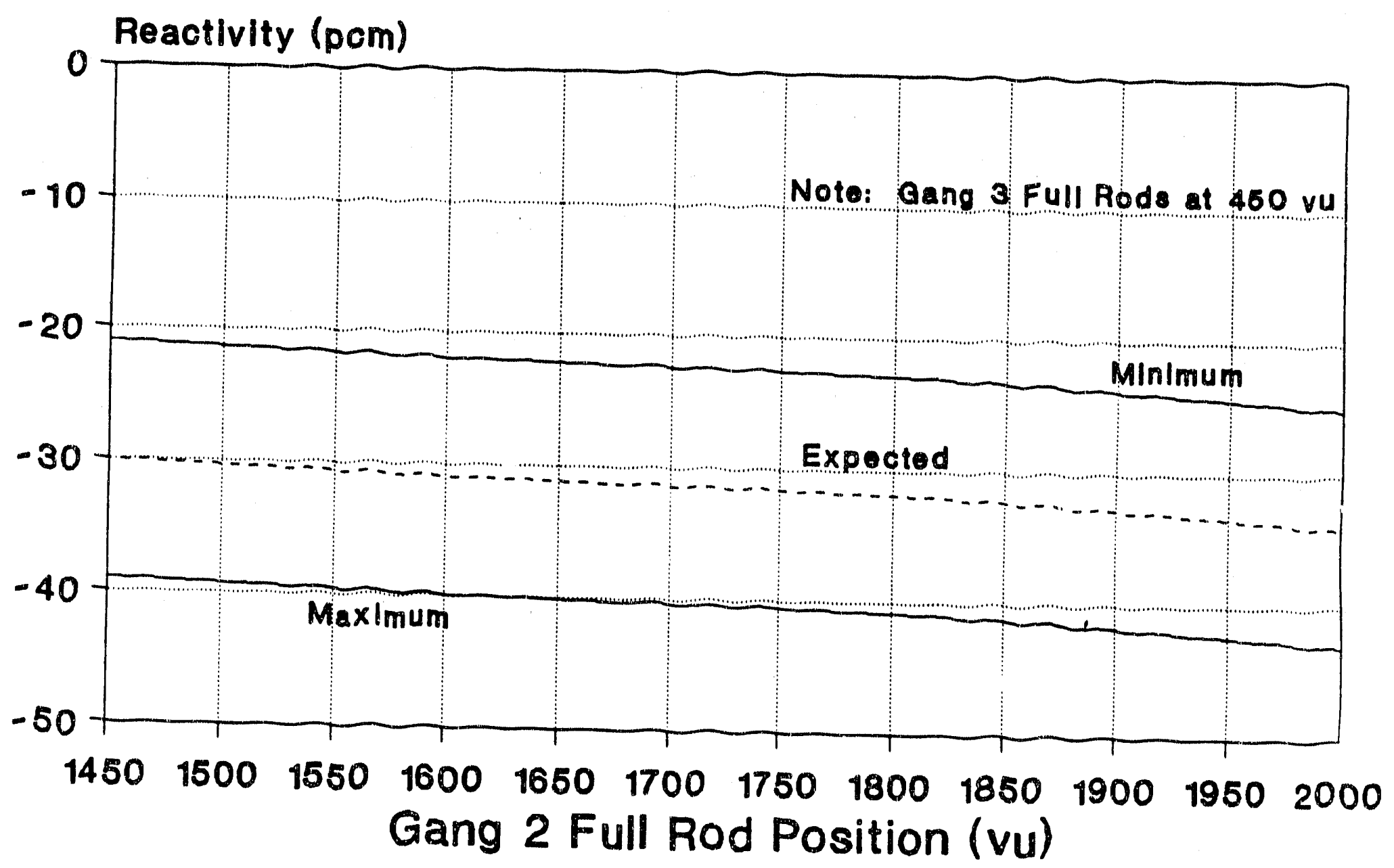


FIGURE 64

\section{Cluster 54 Strong Li Integral Rod Insertion at $60 \%$ Power}

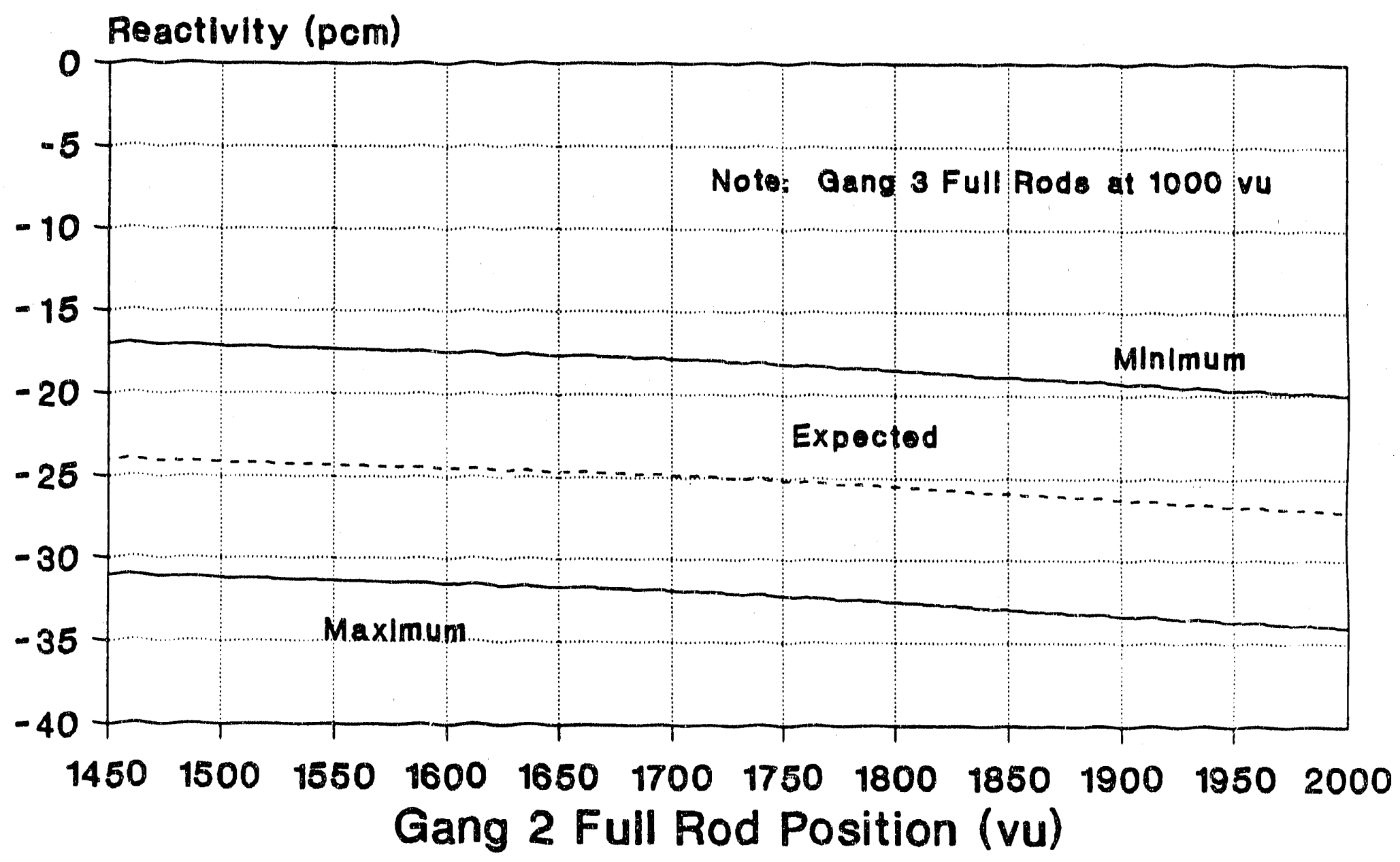


WSRC-TR-91-42-043

Page 93 of 138

June 4, 1991

FIGURE 65

\section{Cluster 1 Strong Partial Rod Insertion $800 \mathrm{vu}$ to $1000 \mathrm{vu}$ at $60 \%$ Power}

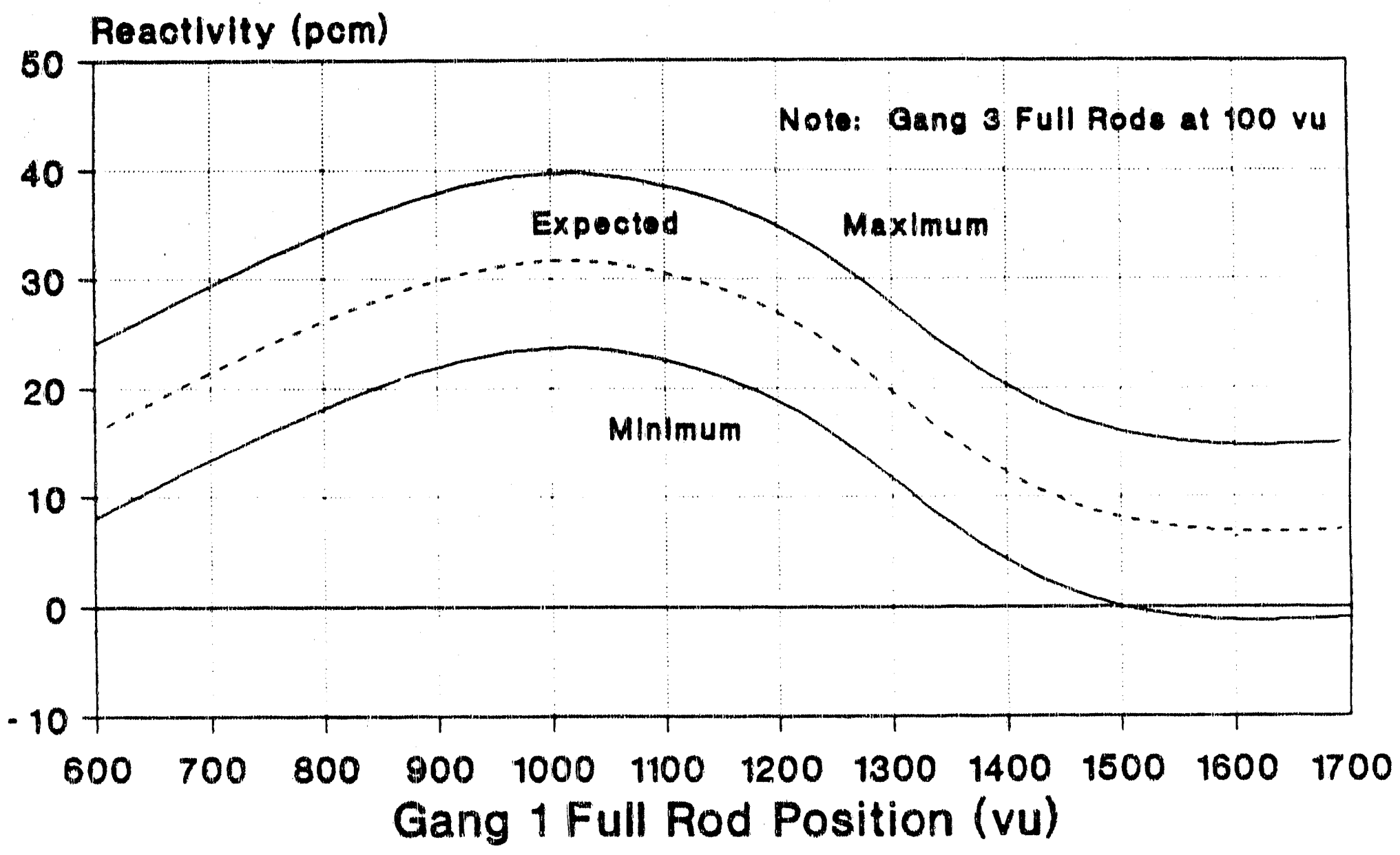


WSRC-TR-91-42-043

Page 94 of 138

June 4, 1991

FIGURE 66

\section{Cluster 1 Strong Partial Rod Insertior $800 \mathrm{vu}$ to $1000 \mathrm{vu}$ at $60 \%$ Power}

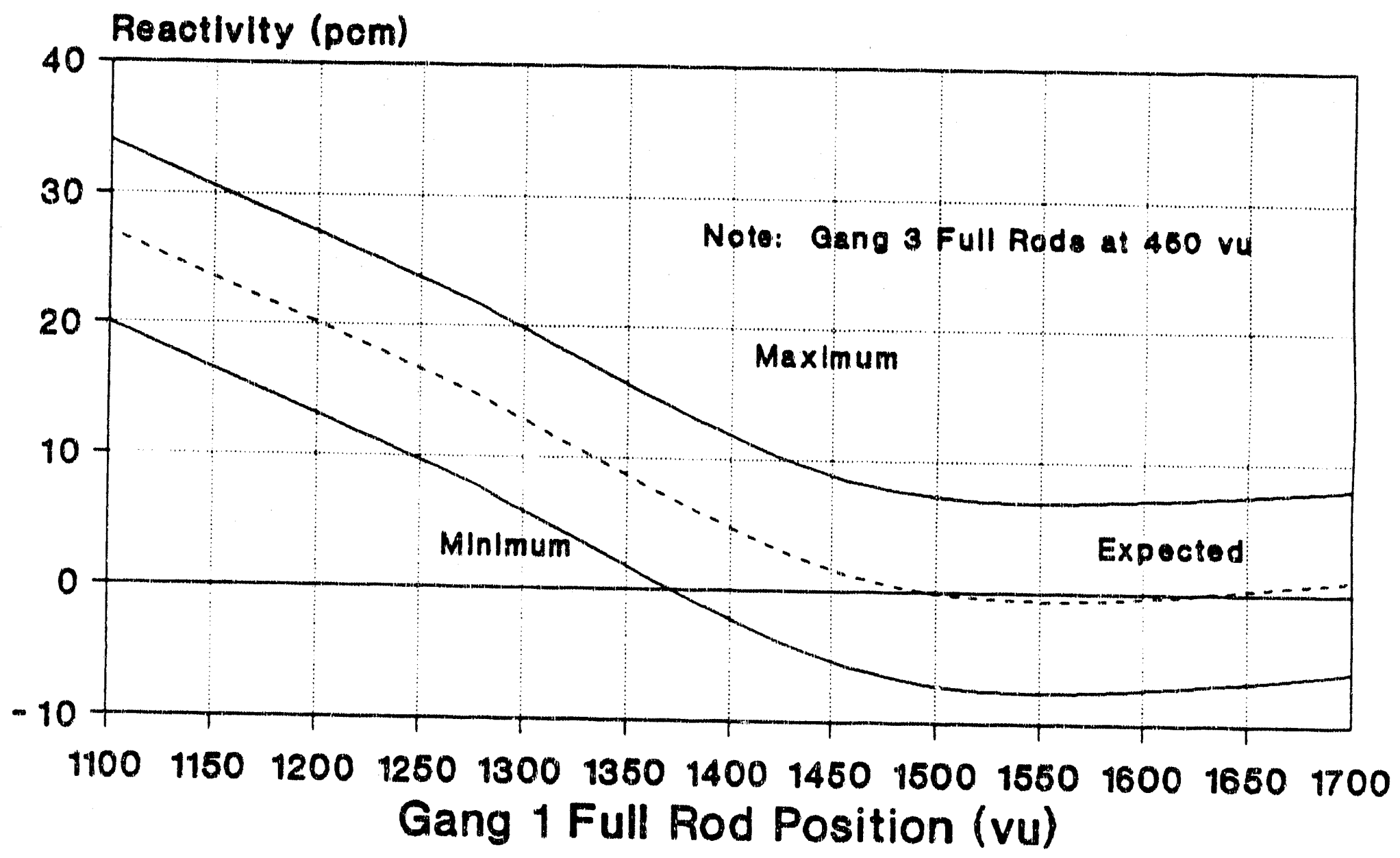


WSRC-TR-91-42-043

Page 95 of 138

June 4, 1991

FIGURE 67

\section{Cluster 1 Strong Partial Rod Insertion 800 vu to 1000 vu at $60 \%$ Power}

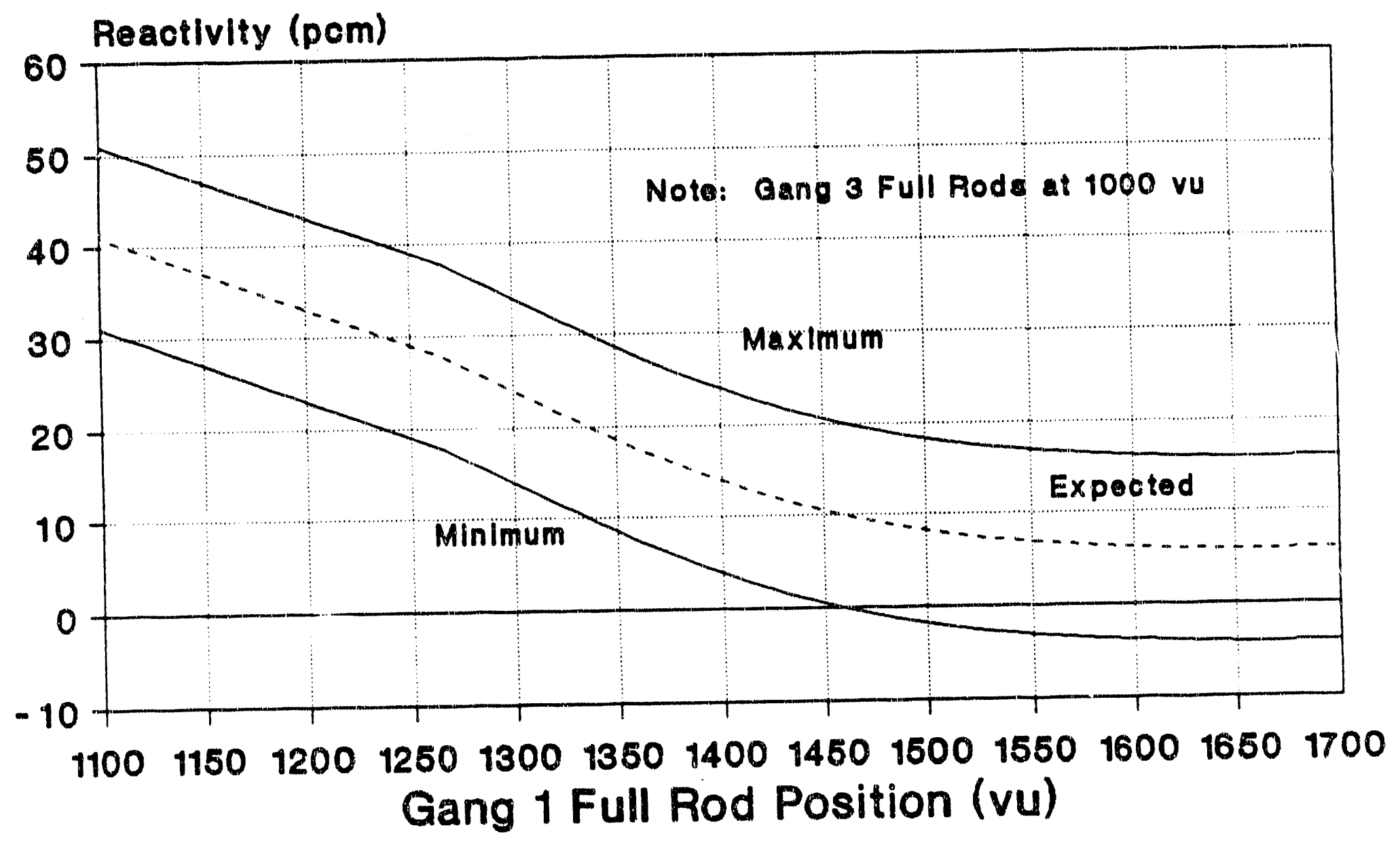


WSRC-TR-91-42-043

Page $96 c^{\prime \prime} 138$

June 4, 15,31

FIGURE 68

\section{Cluster 36 Strong Partial Rod Insertion 800 vu to $1000 \mathrm{vu}$ at $60 \%$ Power}

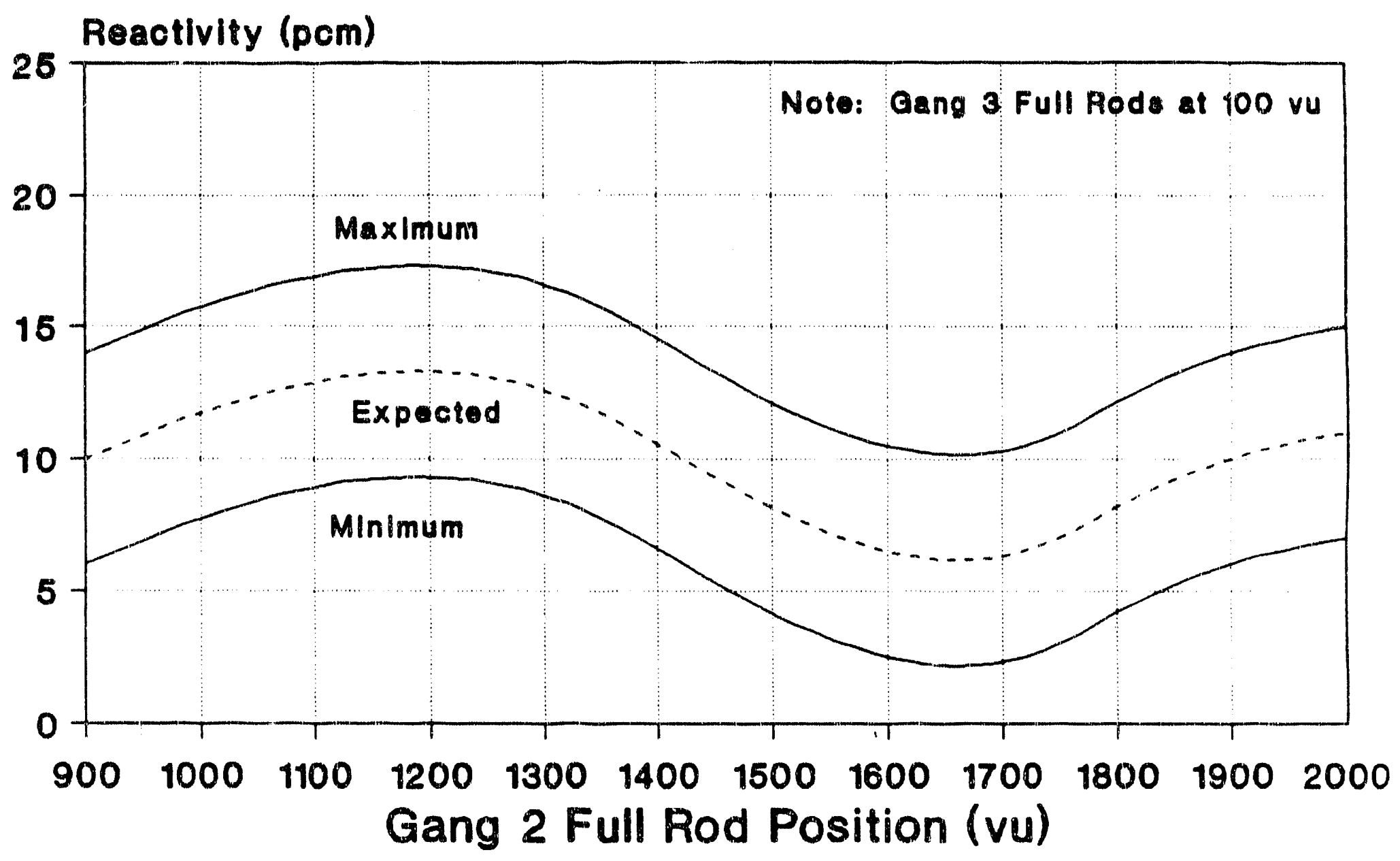


WSRC-TR-91-42-043

Page 97 of 138

June 4, 1991

FIGURE 69

\section{Cluster 36 Strong Partial Rod Insertion 800 vu to 1000 vu at $60 \%$ Power}

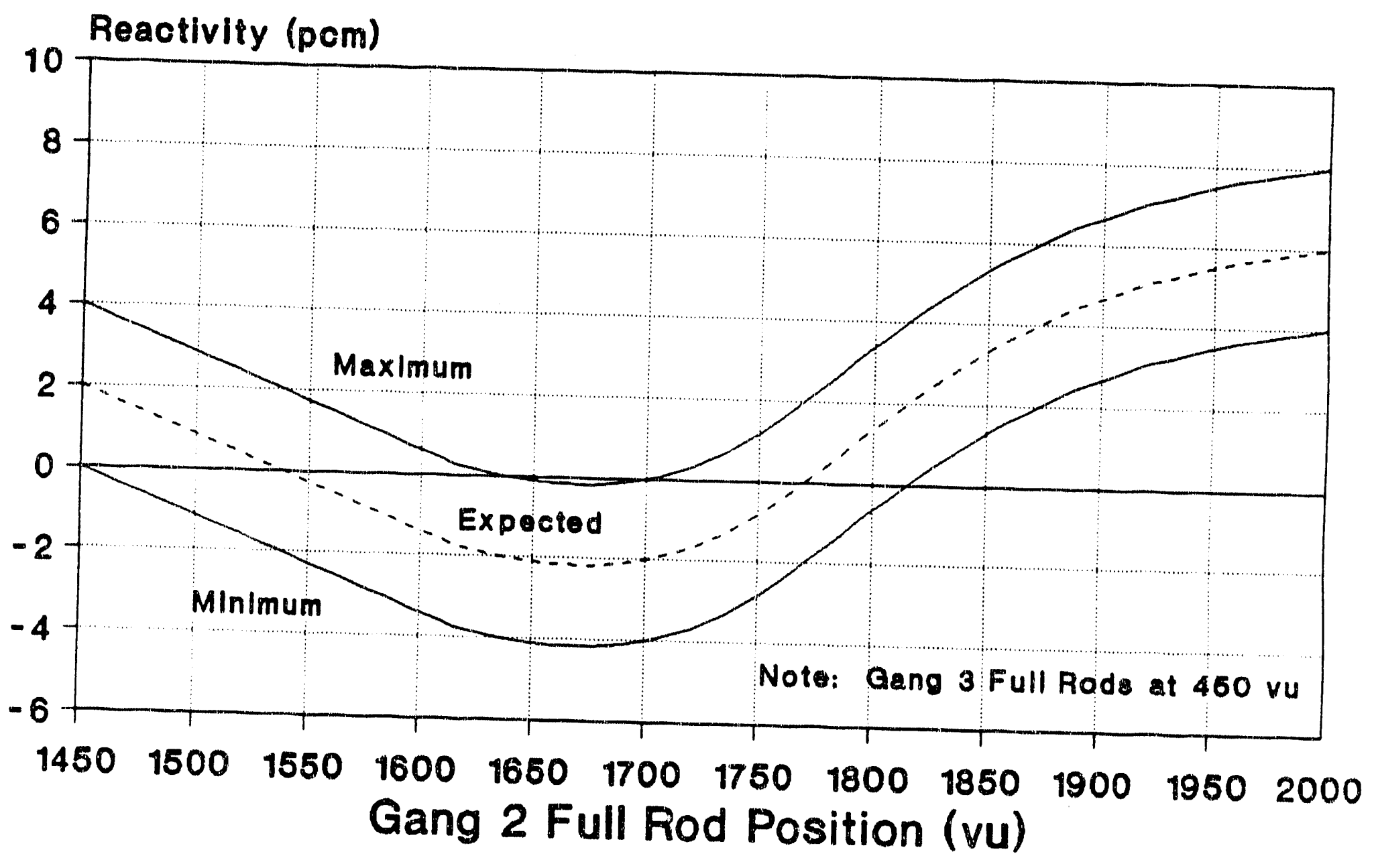


WSRC-TR-91-42-043

Page 98 of 138

June 4, 1991

FIGURE 70

\section{Cluster 36 Strong Partial Rod Insertion $800 \mathrm{vu}$ to $1000 \mathrm{vu}$ at $60 \%$ Power}

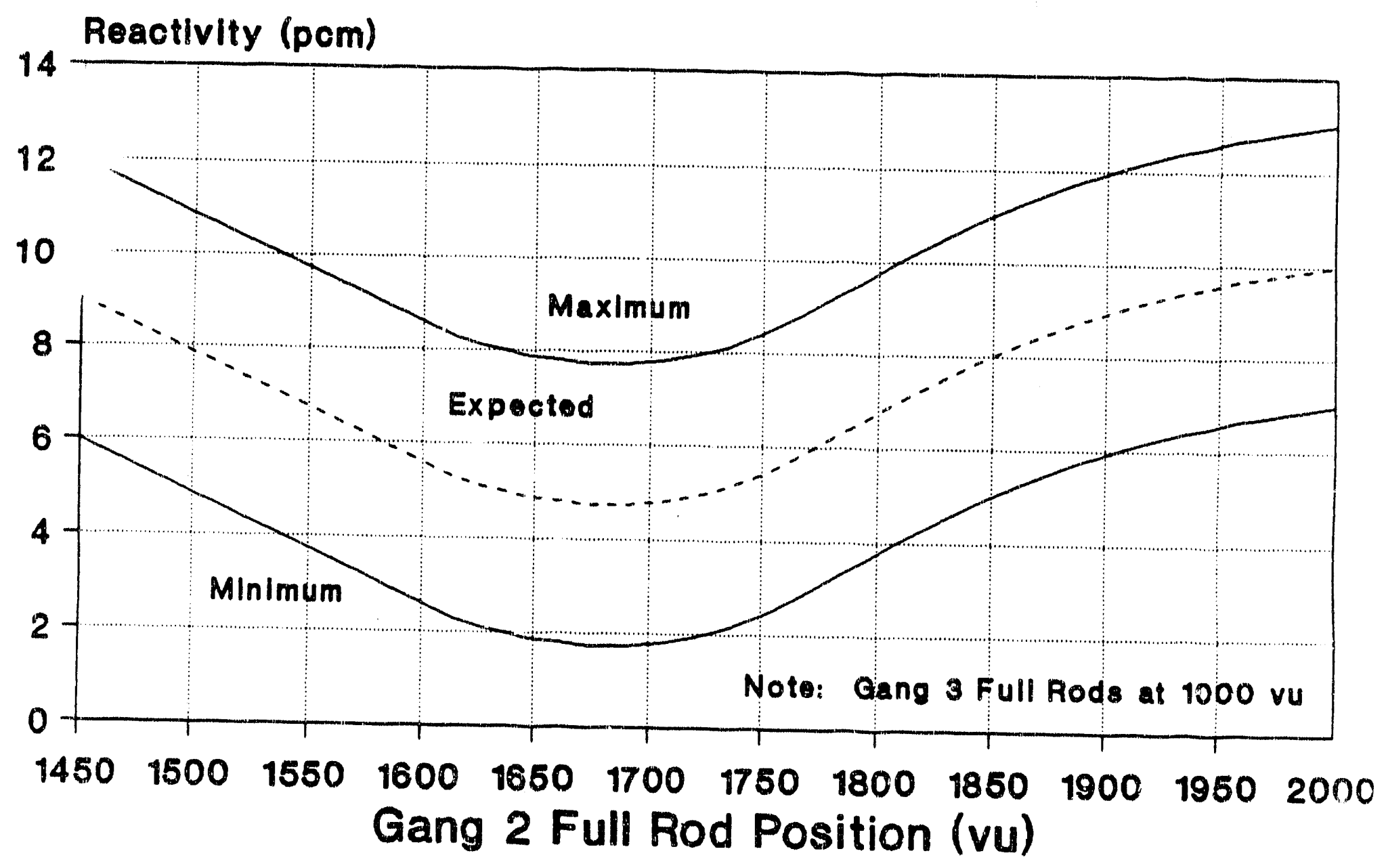


WSRC-TR-91-42-043

Page 99 of 138

June 4, 1991

FIGURE 71

\section{Cluster 52 Strong Partial Rod Insertion $800 \mathrm{vu}$ to $1000 \mathrm{vu}$ at $60 \%$ Power}

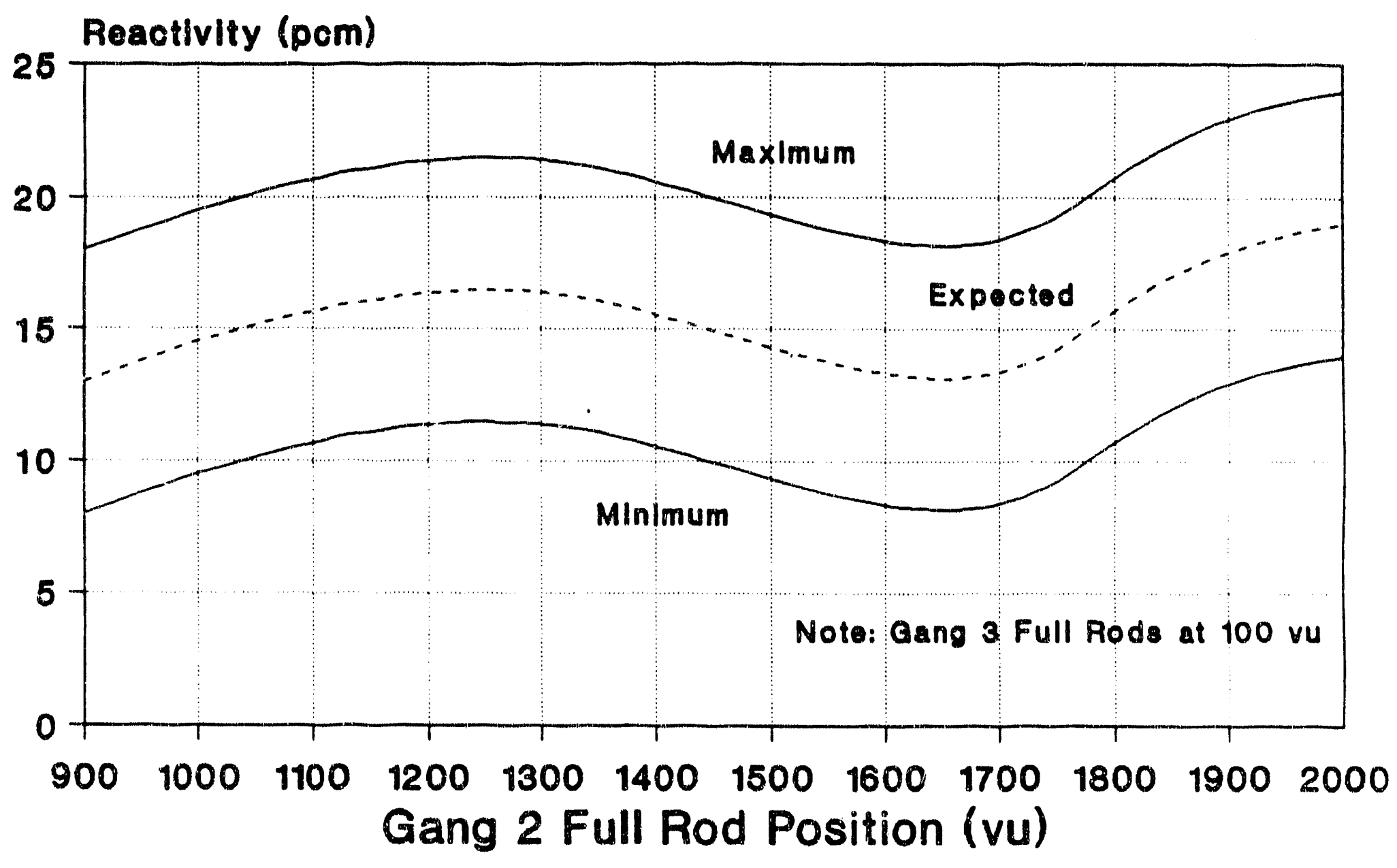


WSRC-TR-91-42-043

Page 100 of 138

June 4, 1991

FIGURE 72

\section{Cluster 52 Strong Partial Rod Insertion 800 vu to 1000 vu at $60 \%$ Power}

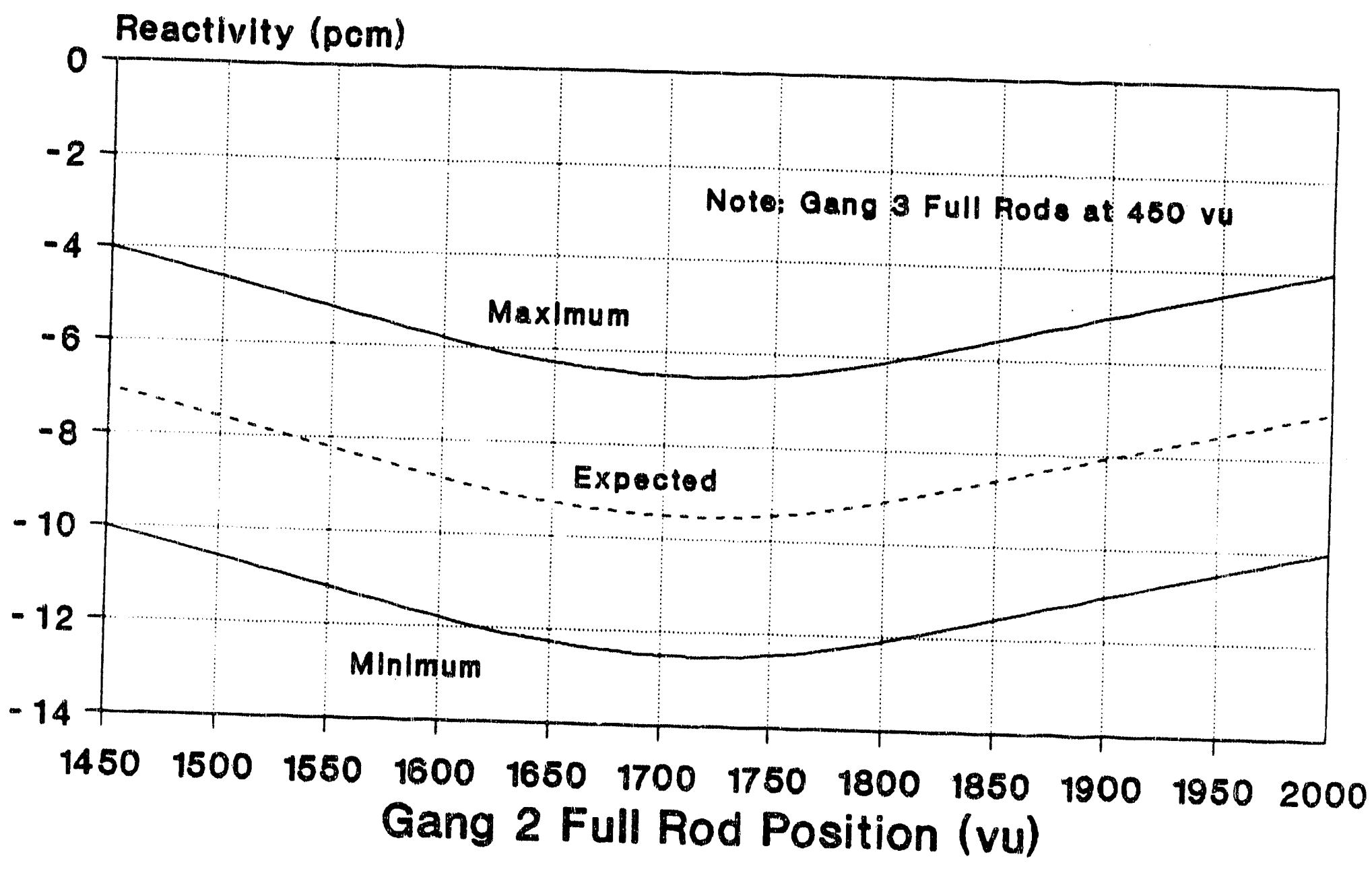


WSRC-TR-91-42-043

Page 101 of 138

June 4, 1991

FIGURE 73

\section{Cluster 52 Strong Partial Rod Insertion $800 \mathrm{vu}$ to $1000 \mathrm{vu}$ at $60 \%$ Power}

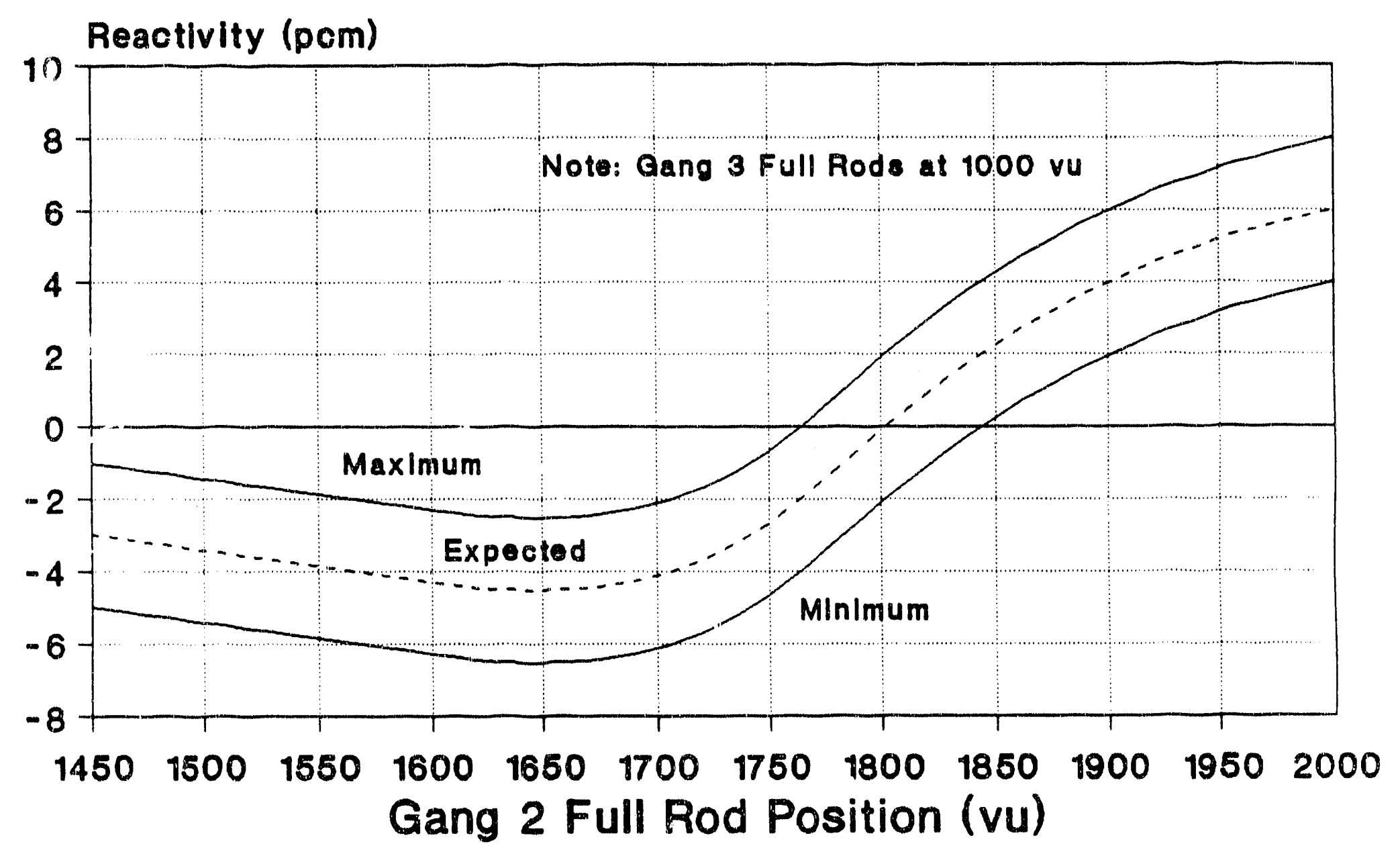


WSRC-TR-91-42-043

Page 102 of 138

June 4, 1991

FIGURE 74

\section{Cluster 1 Weak Partial Rod Insertion 800 vu to 1000 vu at $60 \%$ Power}

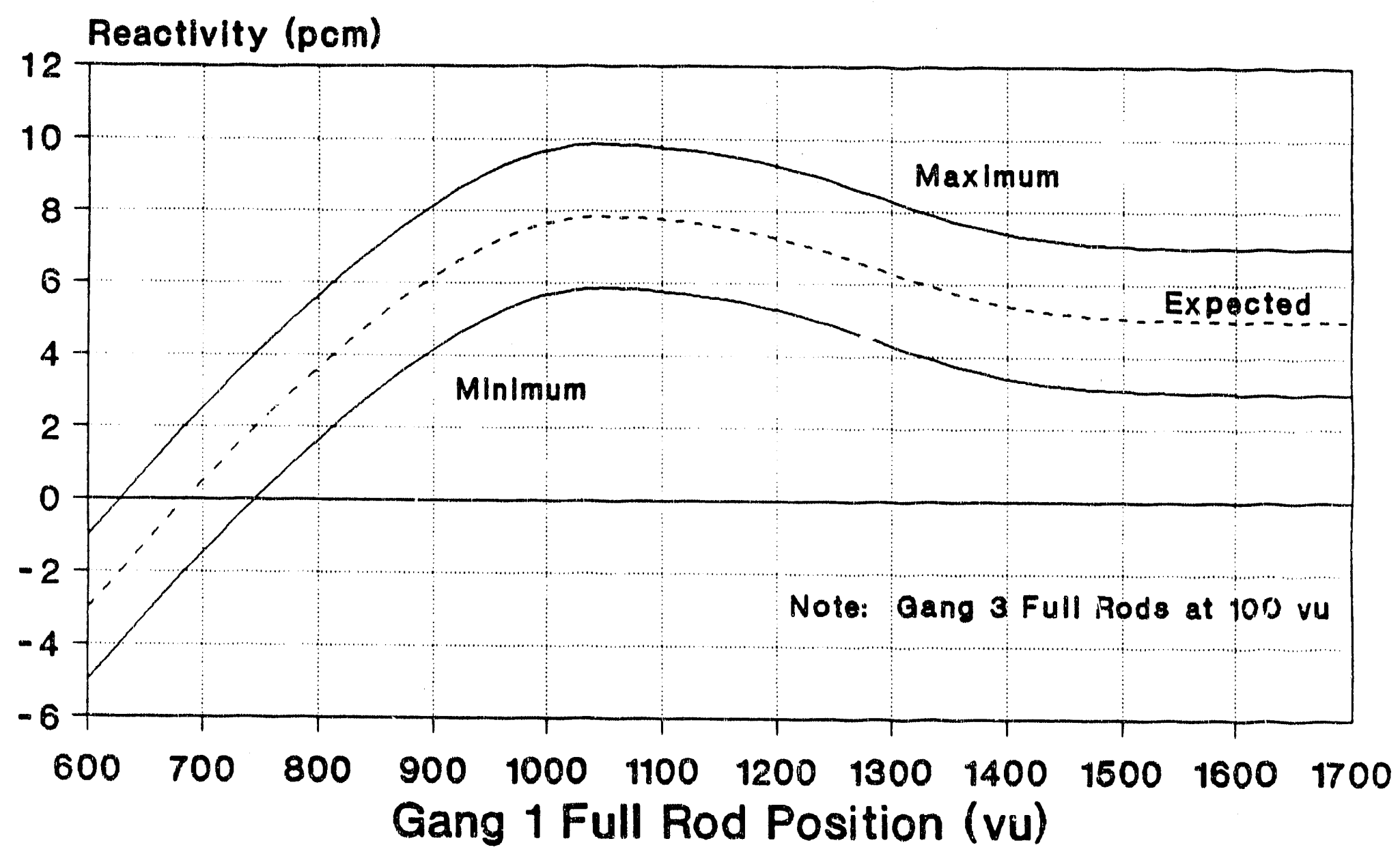


WSRC-TR-91-42-043

Page 103 of 138

June 4, 1991

FIGURE 75

\section{Cluster 1 Weak Partial Rod Insertion 800 vu to 1000 vu at $60 \%$ Power}

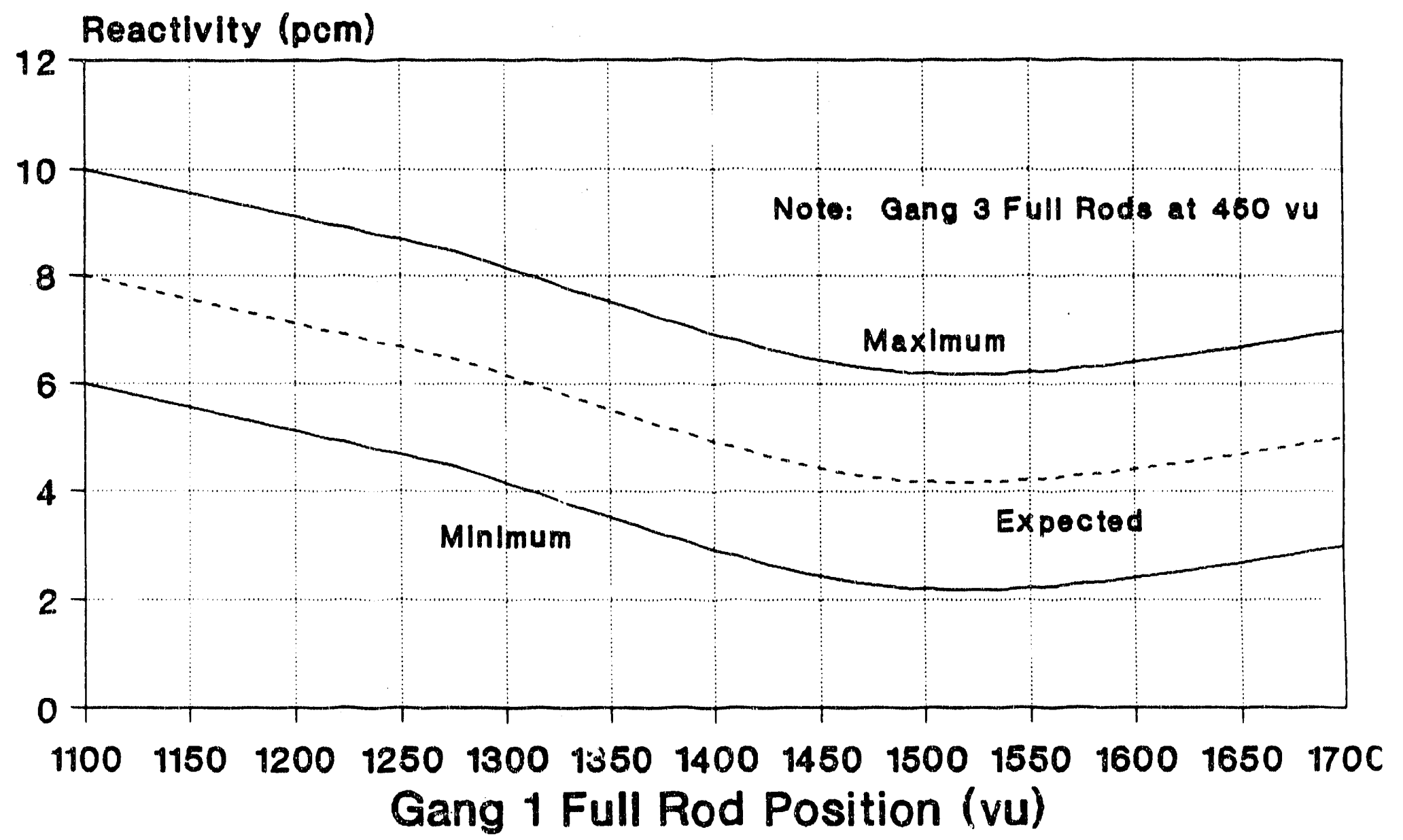


WSRC-TR-91-42-043

Page 104 of 138

June 4, 1991

FIGURE 76

\section{Cluster 1 Weak Partial Rod Insertion $800 \mathrm{vu}$ to $1000 \mathrm{vu}$ at $60 \%$ Power}

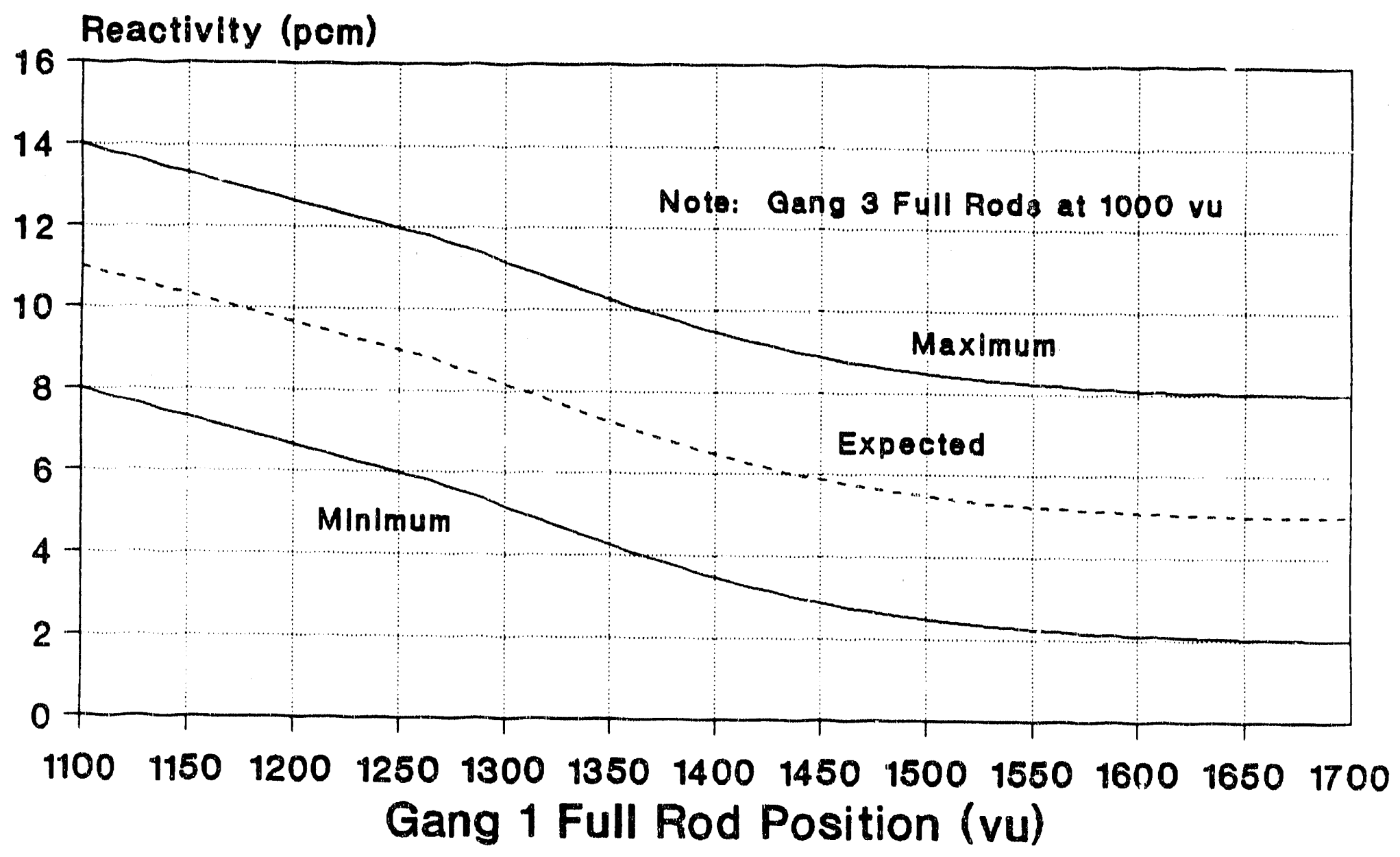


WSRC-TR-91-42-043

Page 105 of 138

June 4, 1991

FIGURE 77

\section{Cluster 36 Weak Partial Rod Insertion 800 vu to 1000 vu at $60 \%$ Power}

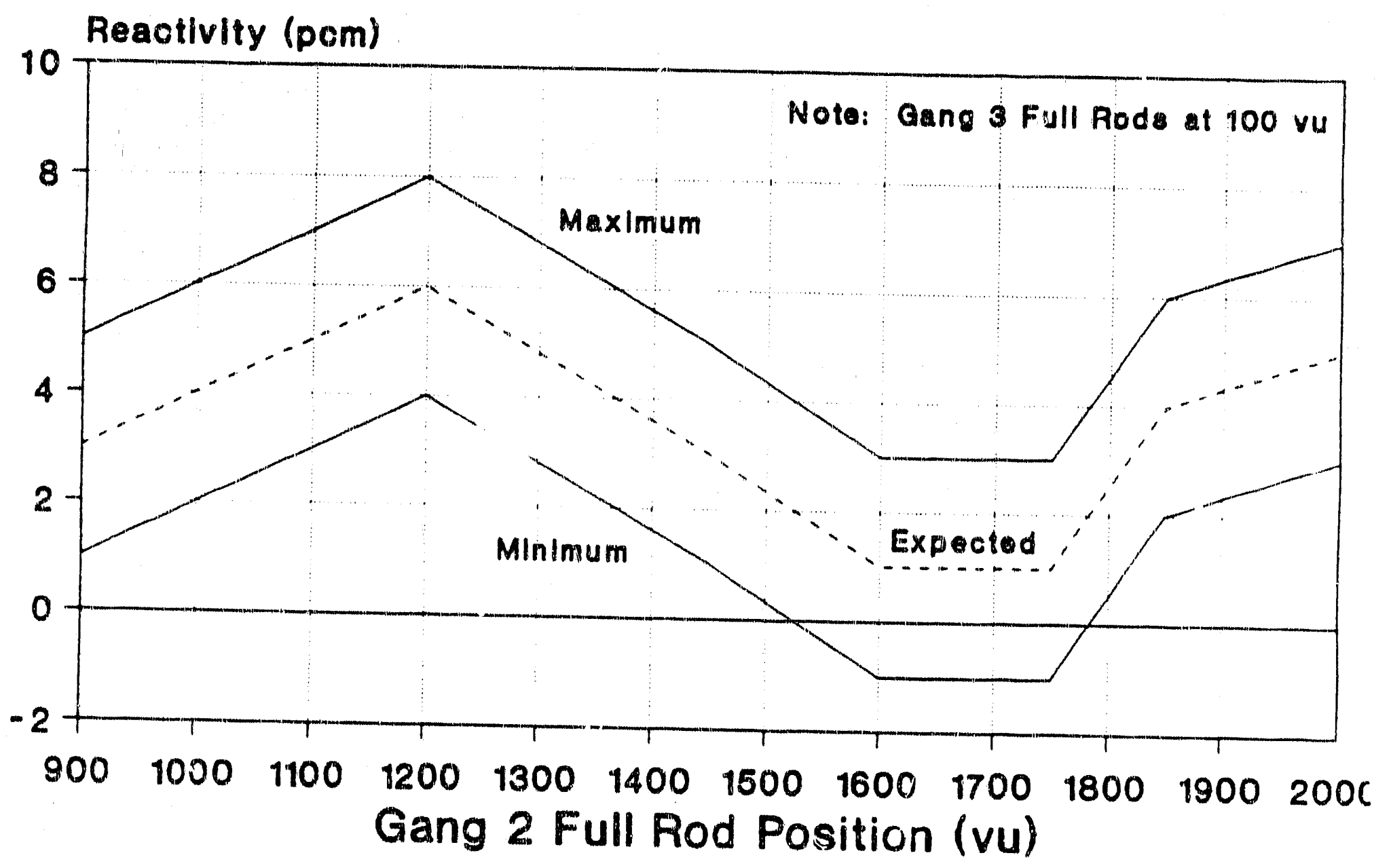


WSRC-TR- $91-42-043$

Page 106 of 138

June 4, 1991

FIGURE 78

\section{Cluster 36 Weak Partial Rod Insertion 800 vu to 1000 vu at $60 \%$ Power}

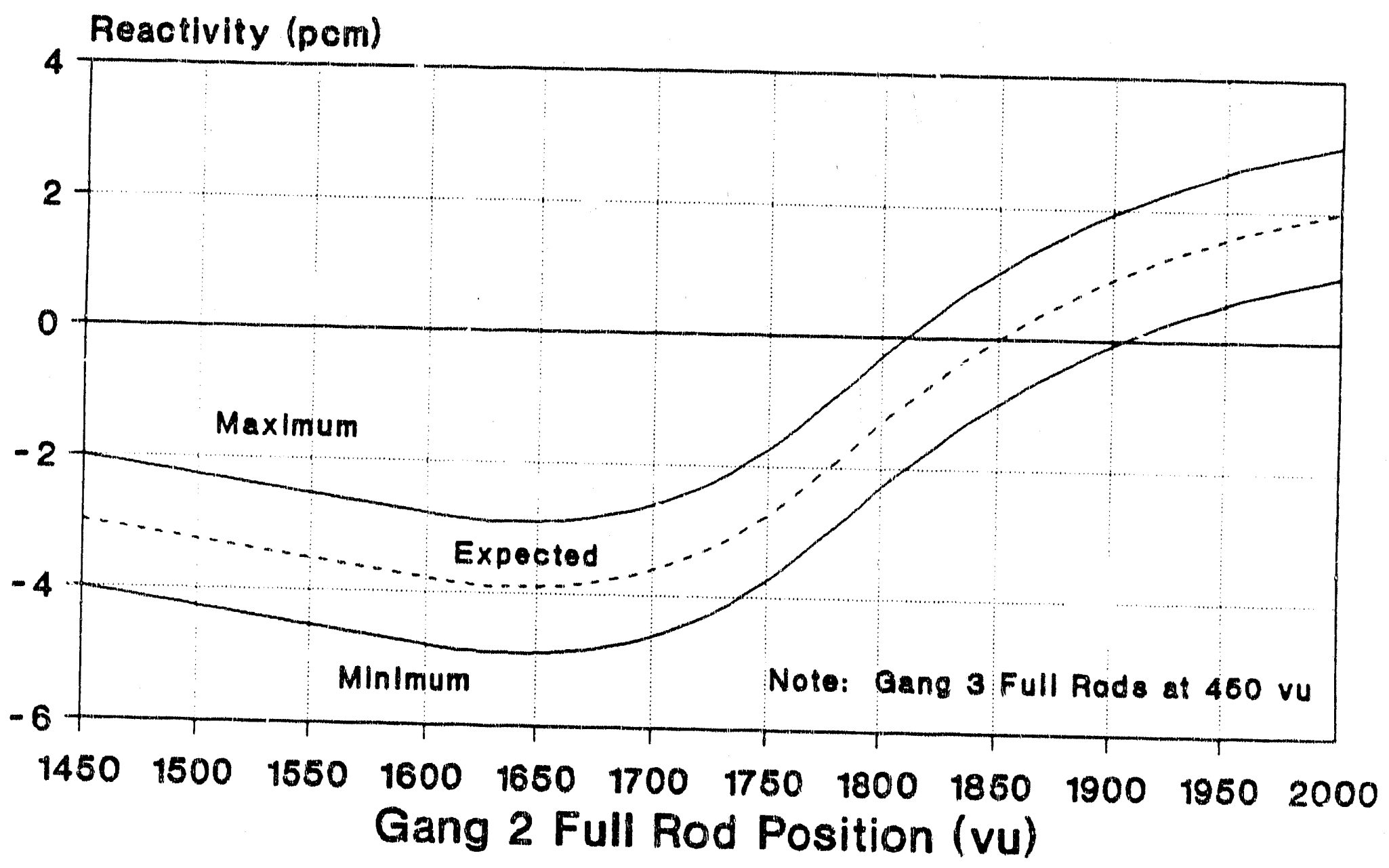


WSRC-TR-91-42-043

Page 107 of 138

June 4, 1991

FIGURE 79

\section{Cluster 36 Weak Partial Rod Insertion 800 vu to 1000 vu at $60 \%$ Power}

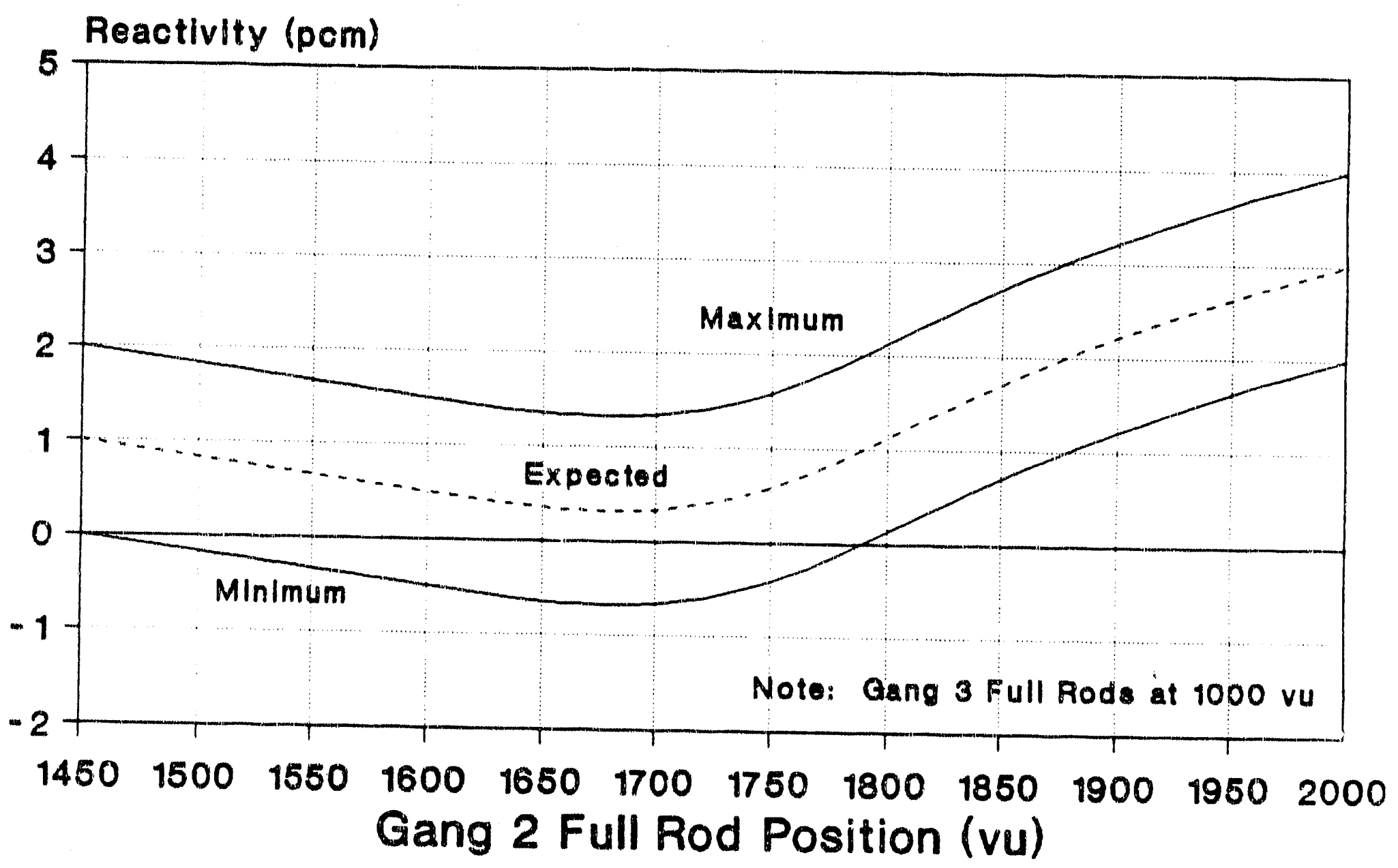


WSRC-TR-91-42-043

Page 108 of 138

June 4, 1991

FIGURE 80

\section{Cluster 52 Weak Partial Rod Insertion 800 vu to 1000 vu at $60 \%$ Power}

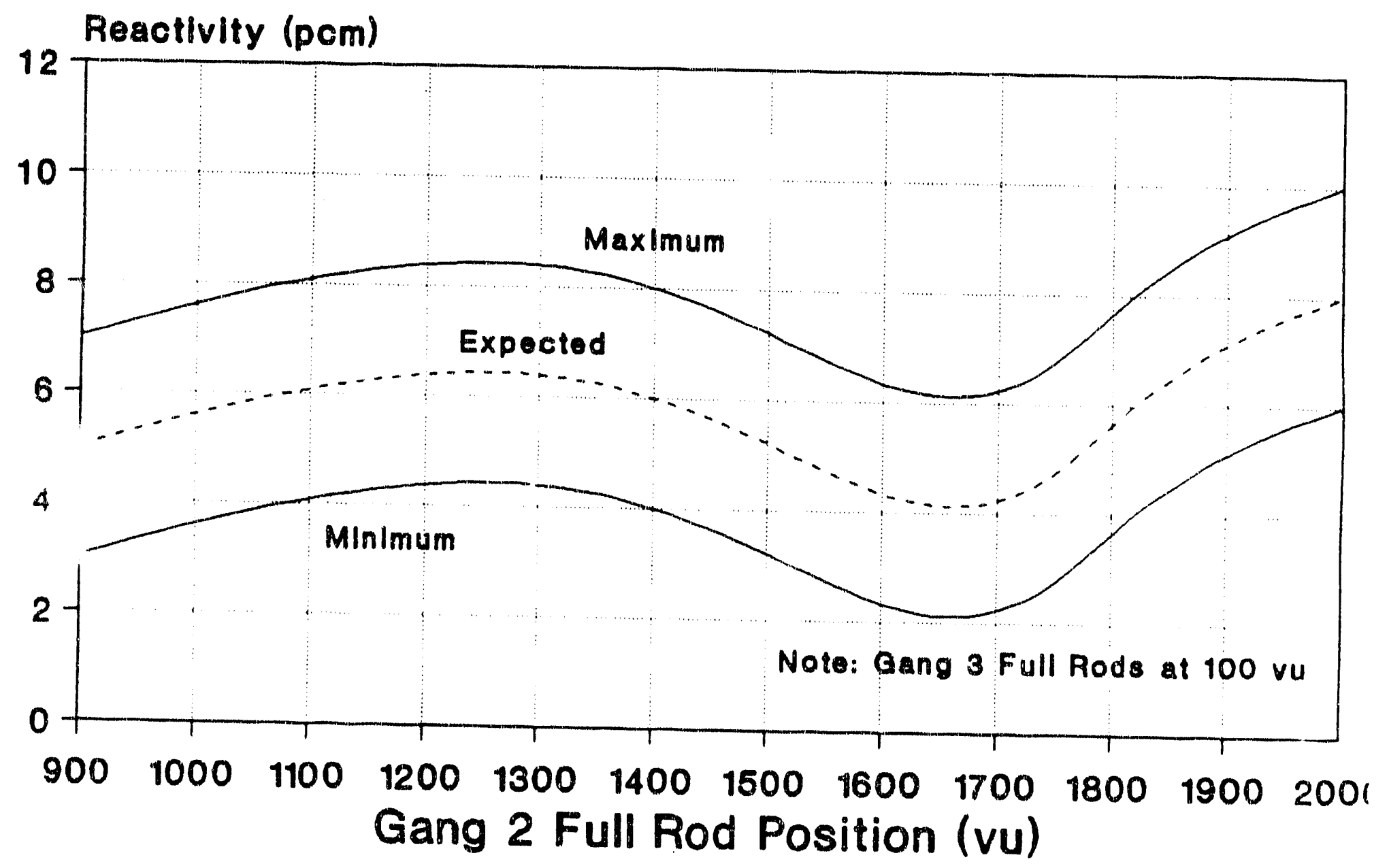


WSRC-TR-91-42-043

Page 109 of 138

June 4, 1991

FIGURE 81

\section{Cluster 52 Weak Partial Rod Insertion 800 vu to 1000 vu at $60 \%$ Power}

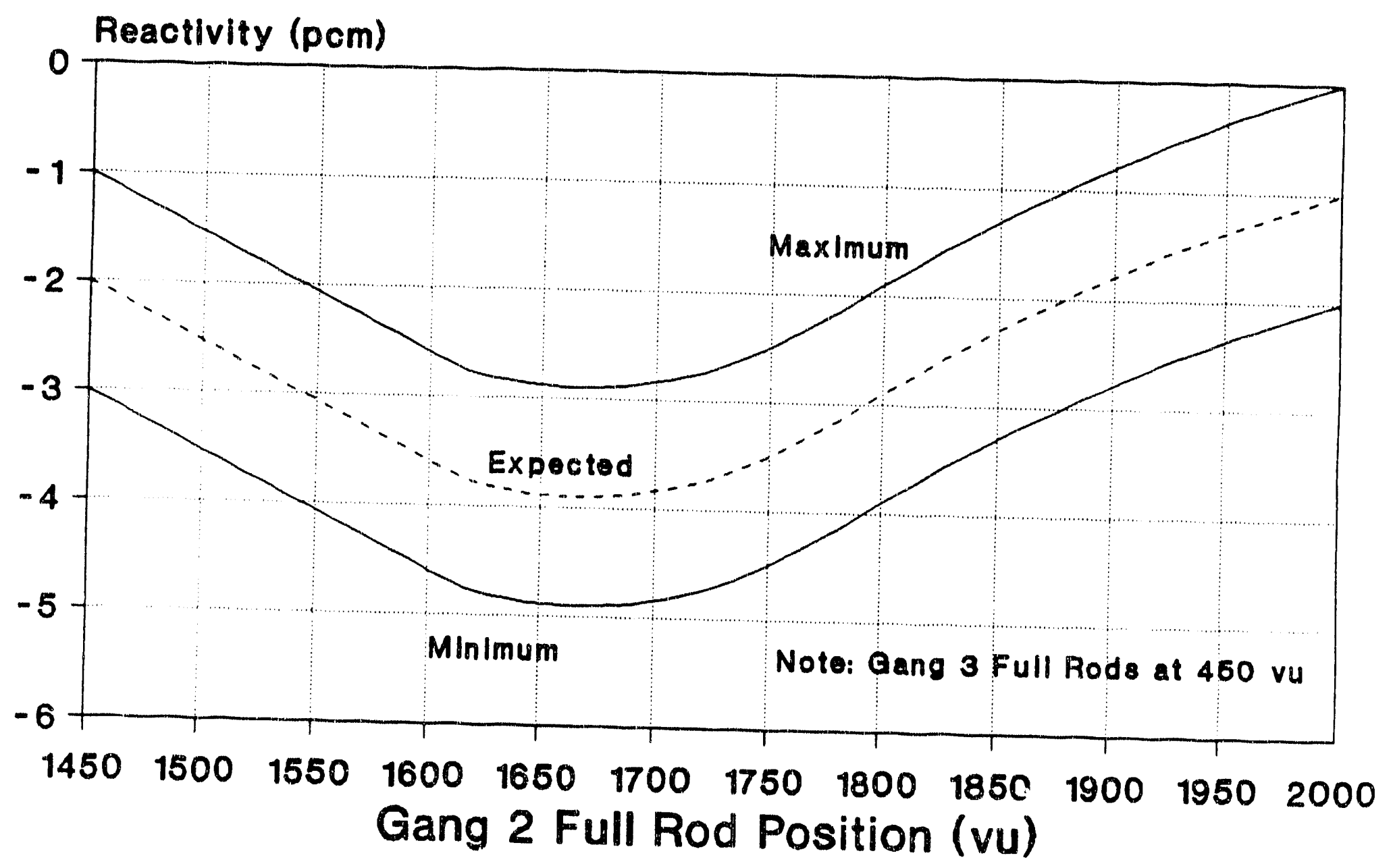


WSRC-TR-91-42-043

Page 110 of 138

June 4, 1991

FIGURE 82

\section{Cluster 52 Weak Partial Rod Insertion 800 vu to 1000 vu at $60 \%$ Power}

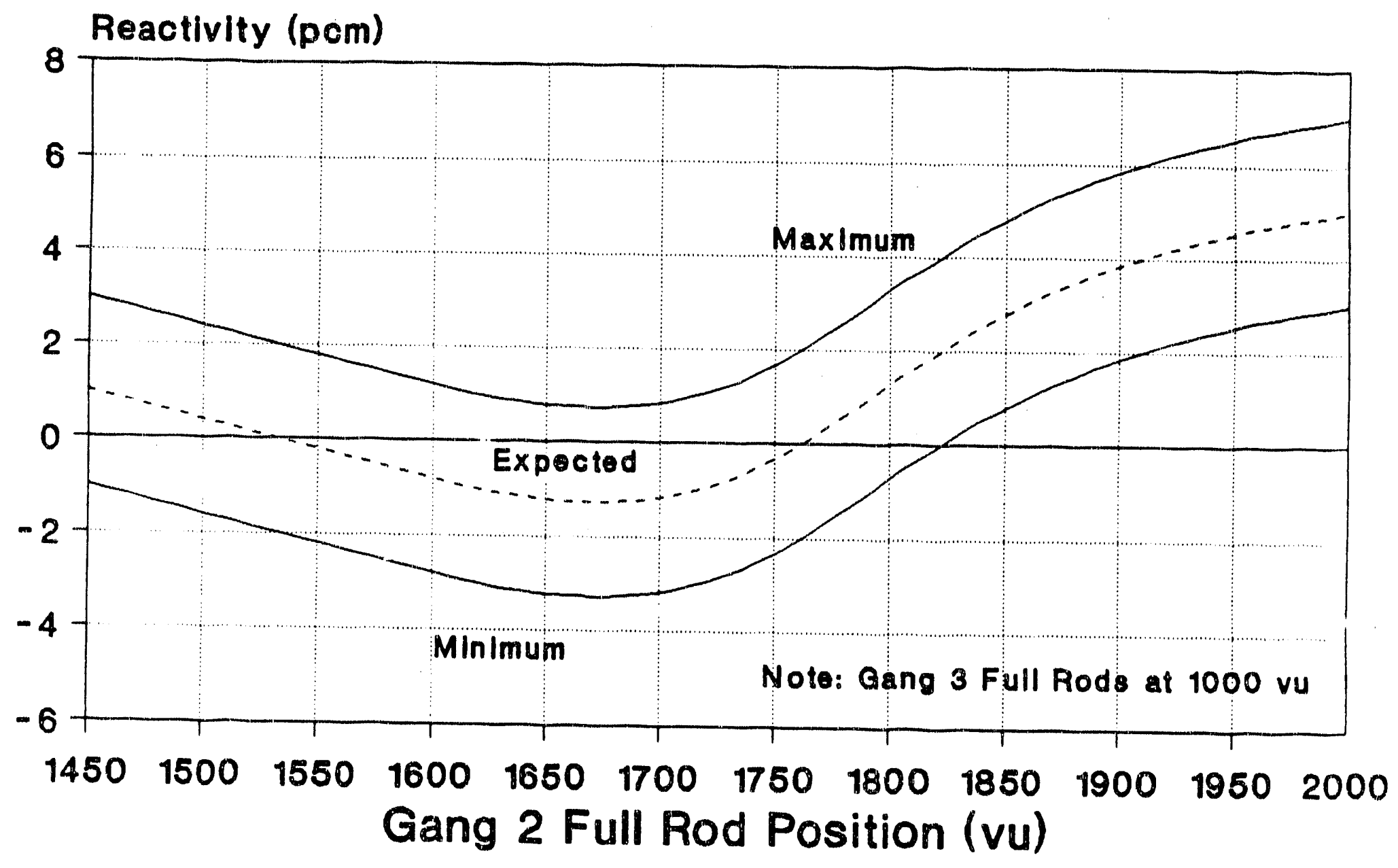


WSRC-TR-91-42-0,43

Page 111 of 138

June 4, 1991

FIGURE 83

\section{Gang 1 Partial Rod Insertion $800 \mathrm{vu}$ to $850 \mathrm{vu}$ at $60 \%$ Power}

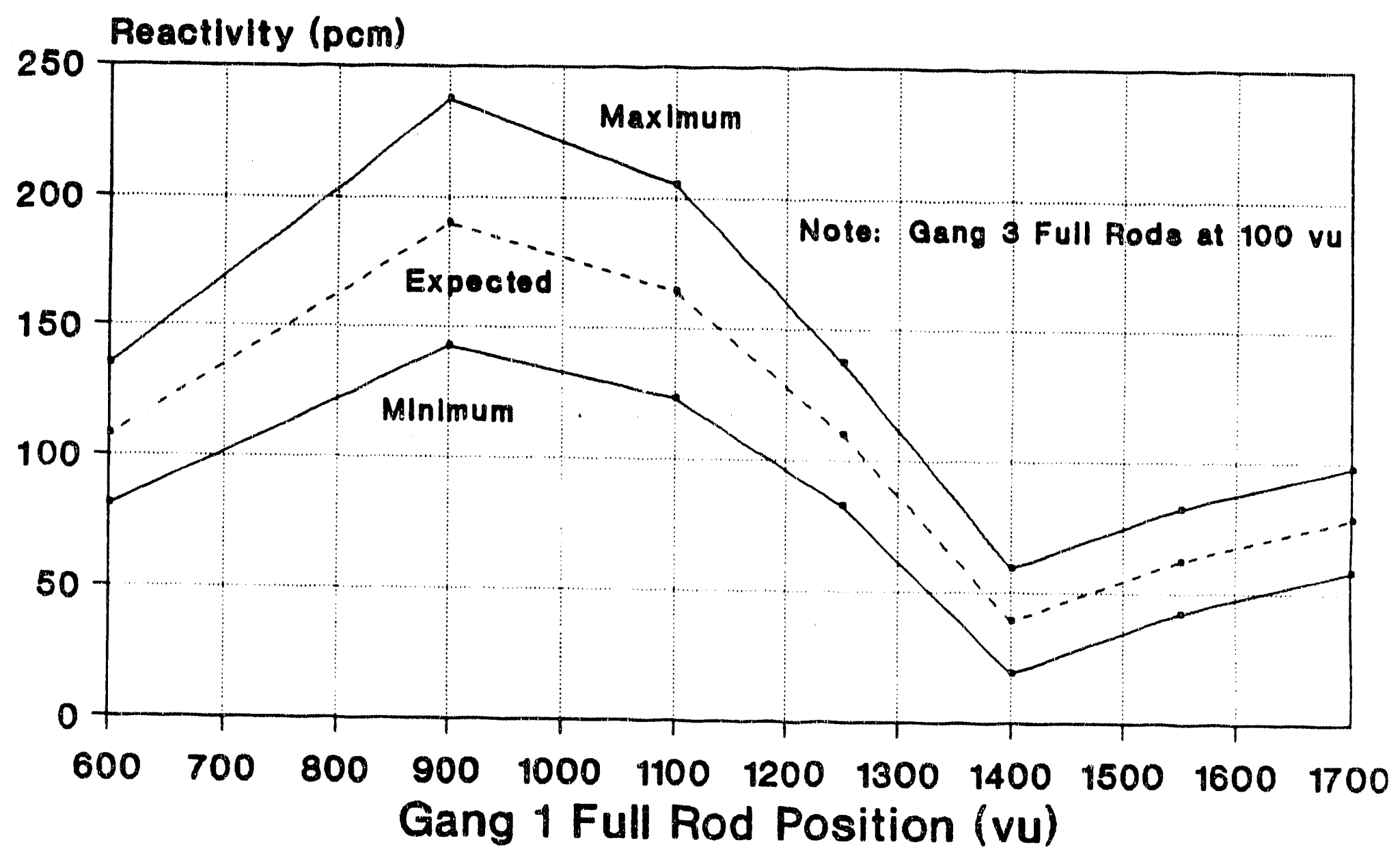


WSRC-TR-91-42-043

Page 112 of 138

June 4, 1991

FIGURE 84

\section{Gang 1 Partial Rod Insertion 800 vu to 850 vu at $60 \%$ Power}

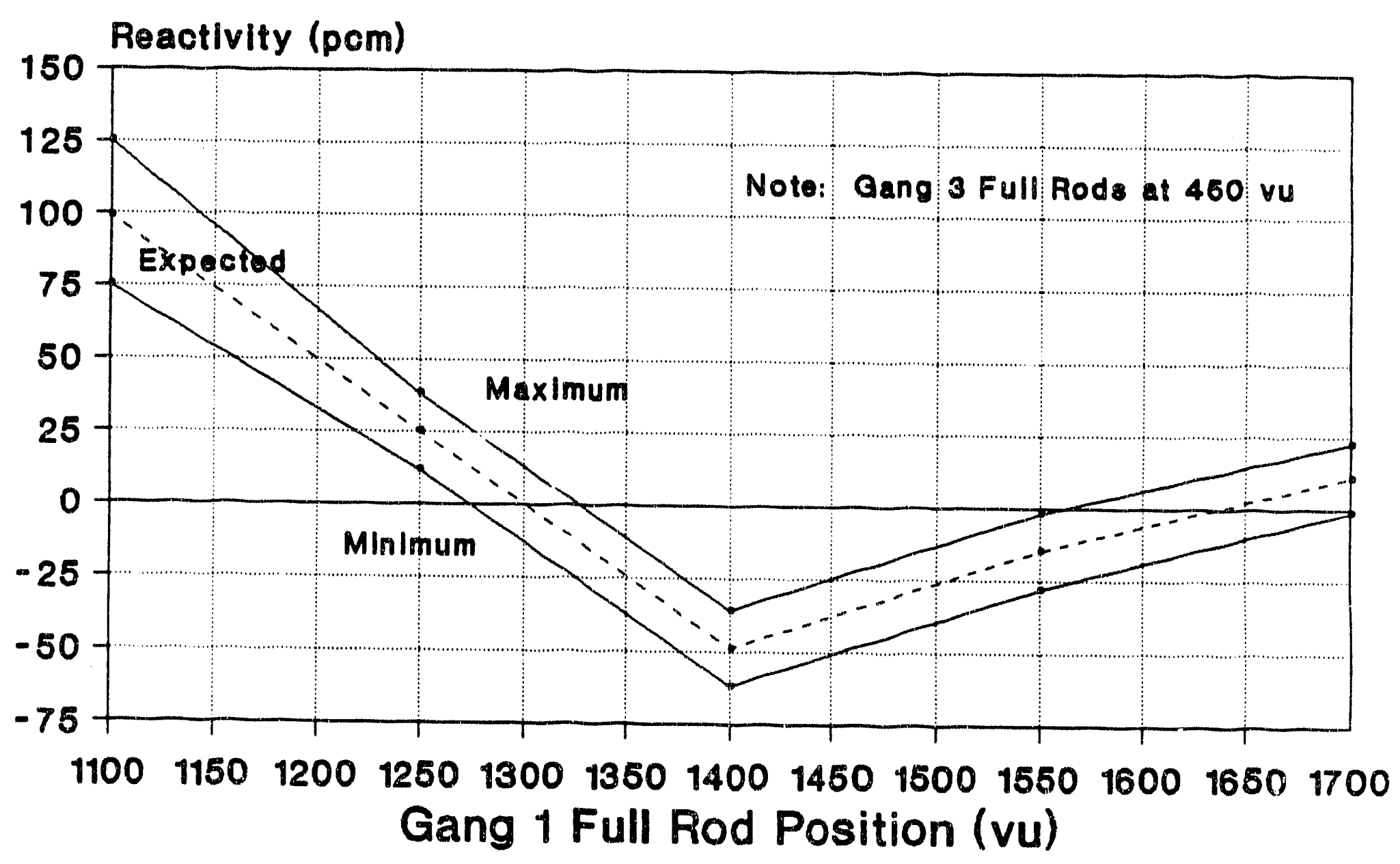


WSRC-TR-91-42-043

Page 113 of 138

June 4, 1991

FIGURE 85

\section{Gang 1 Partial Rod Insertion 800 vu to 850 vu at $60 \%$ Power}

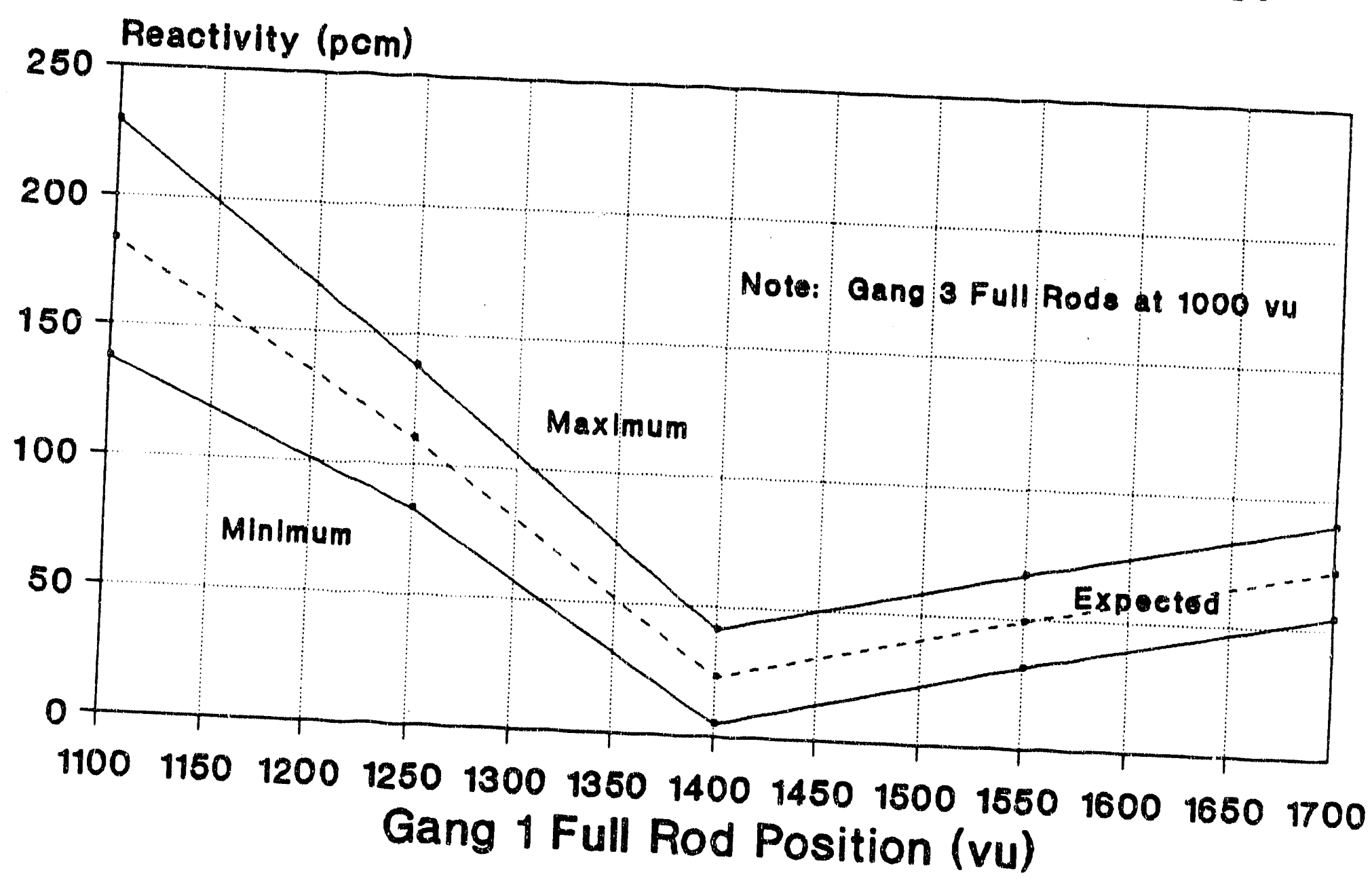


FIGURE 86

\section{Gang 2 Partial Rod Insertion 800 vu to 850 vu at $60 \%$ Power}

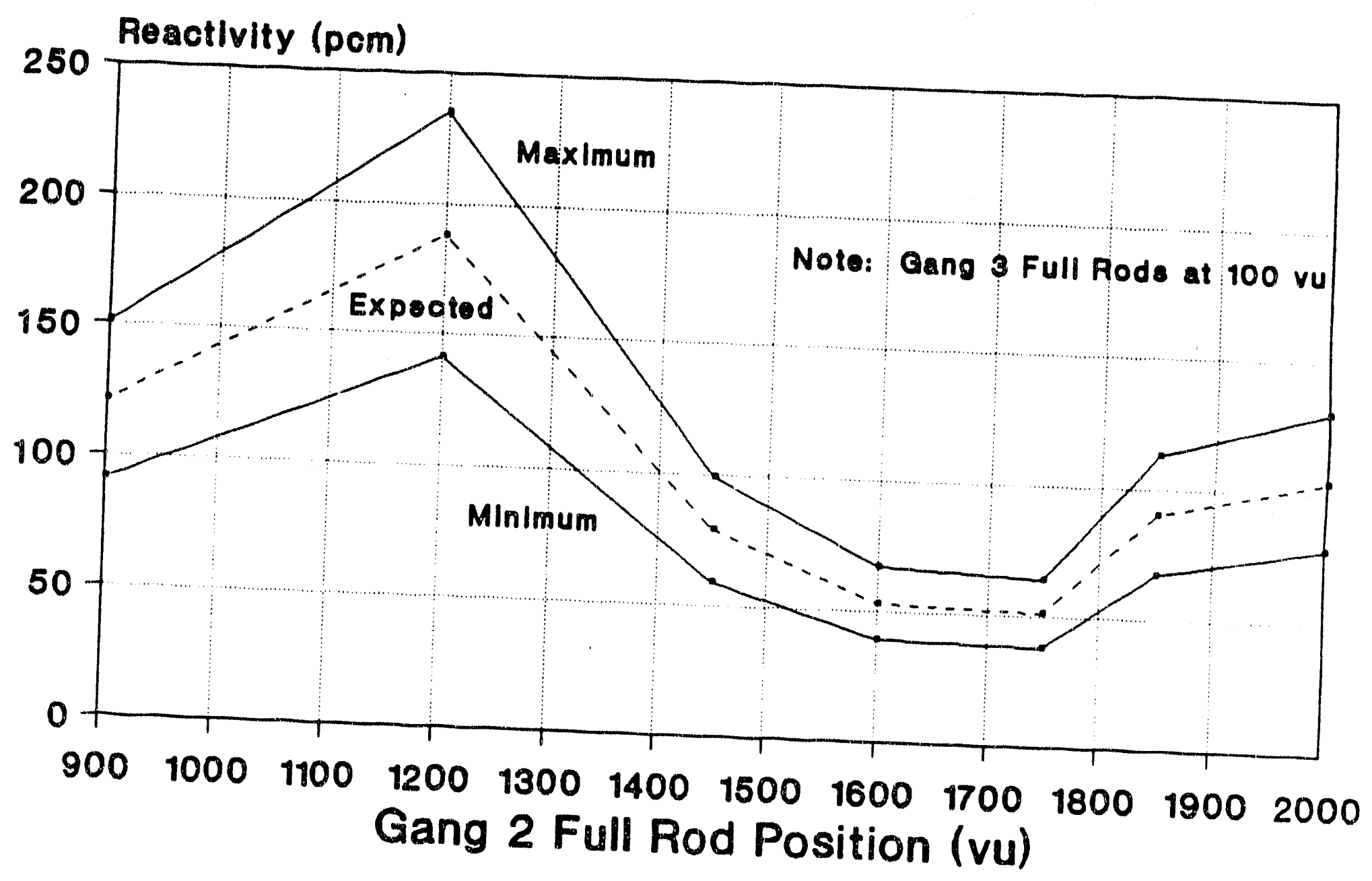


WSRC-TR-91-42-043

Page 115 of 138

June 4, 1991

FIGURE 87

\section{Gang 2 Partial Rod Insertion $800 \mathrm{vu}$ to $850 \mathrm{vu}$ at $60 \%$ Power}

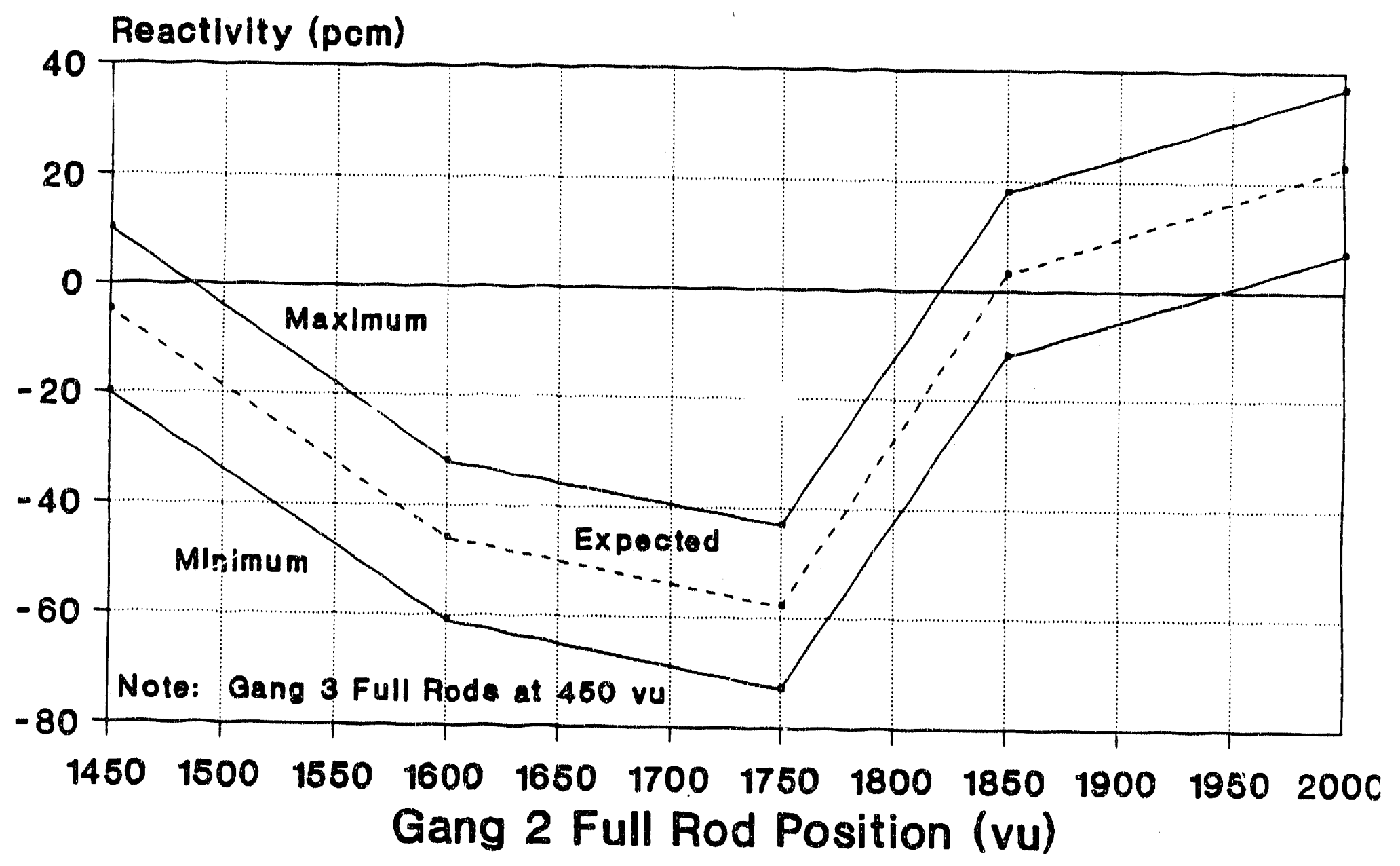


WSRC-TR-91-42-043

Page 116 of 138

June 4, 1991

FIGURE 88

\section{Gang 2 Partial Rod Insertion $800 \mathrm{vu}$ to $850 \mathrm{vu}$ at $60 \%$ Power}

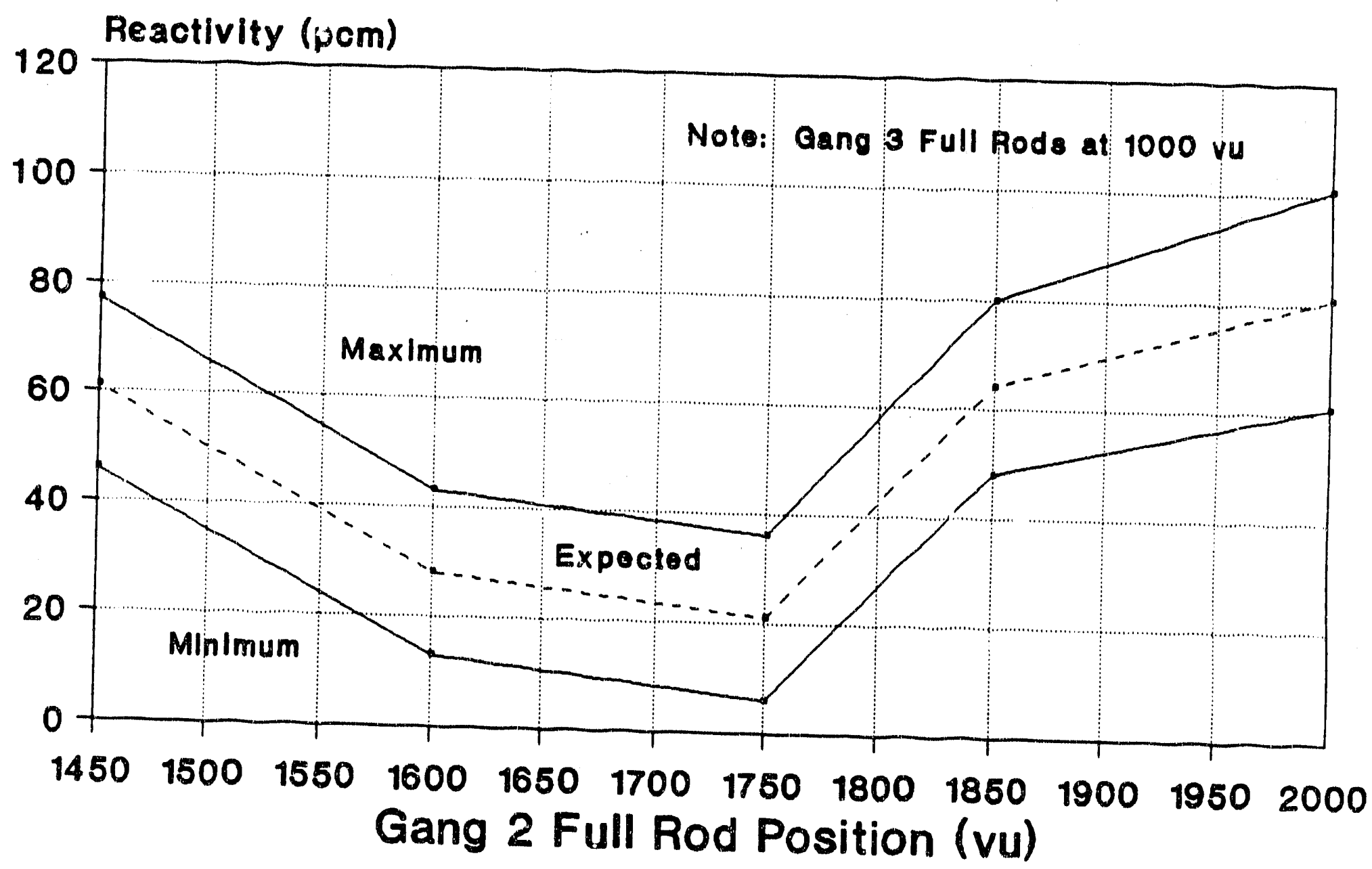


WSRC-TR-91-42-043

Page 117 of 138

June 4, 1991

FIGURE 89

\section{Gang 3 Partial Rod Insertion $800 \mathrm{vu}$ to $850 \mathrm{vu}$ at $60 \%$ Power}

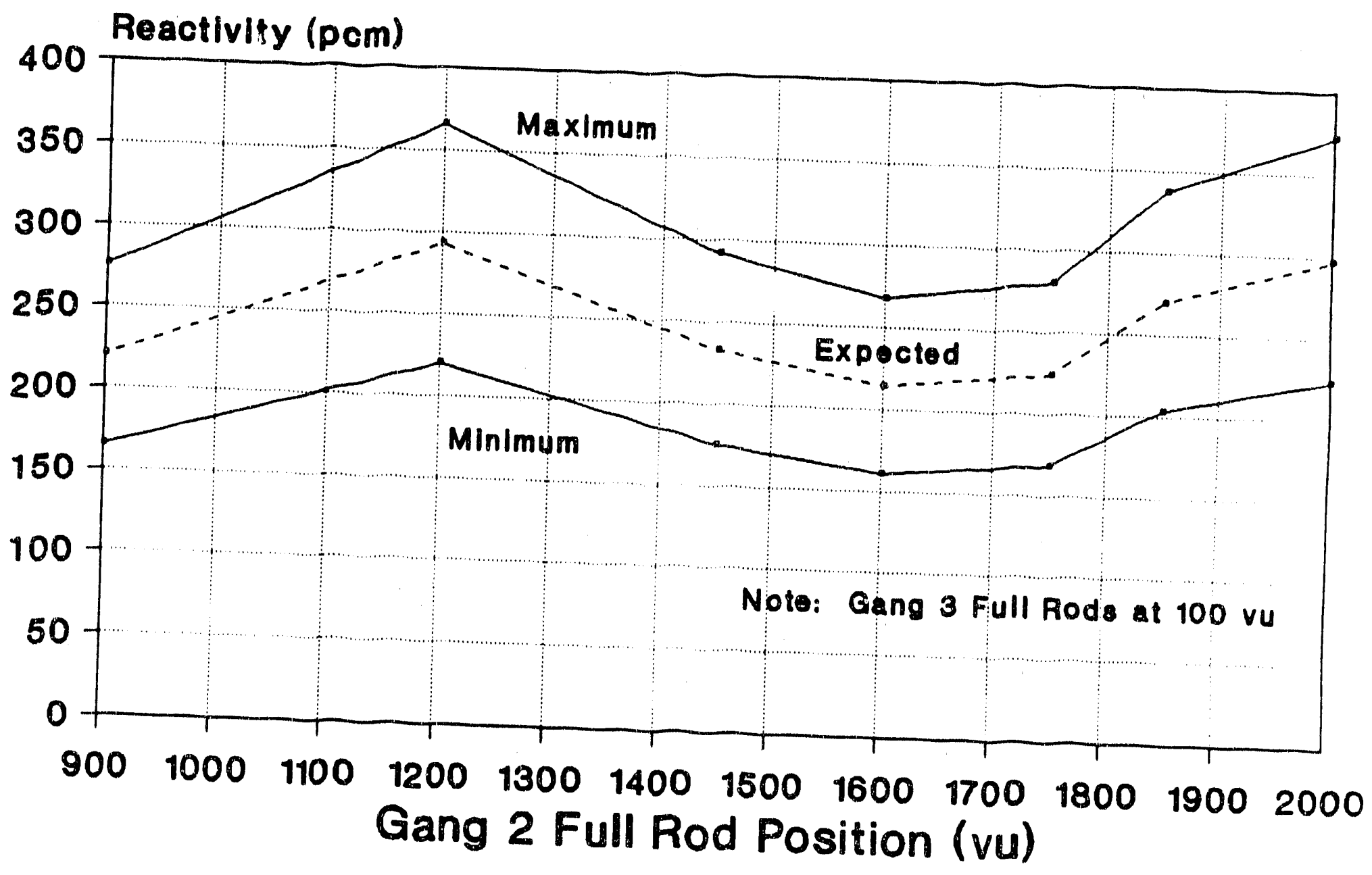


WSRC-TR-91-42-043

Page 118 of 138

June 4, 1991

FIGURE 90

\section{Gang 3 Partial Rod Insertion 800 vu to 850 vu at $60 \%$ Power}

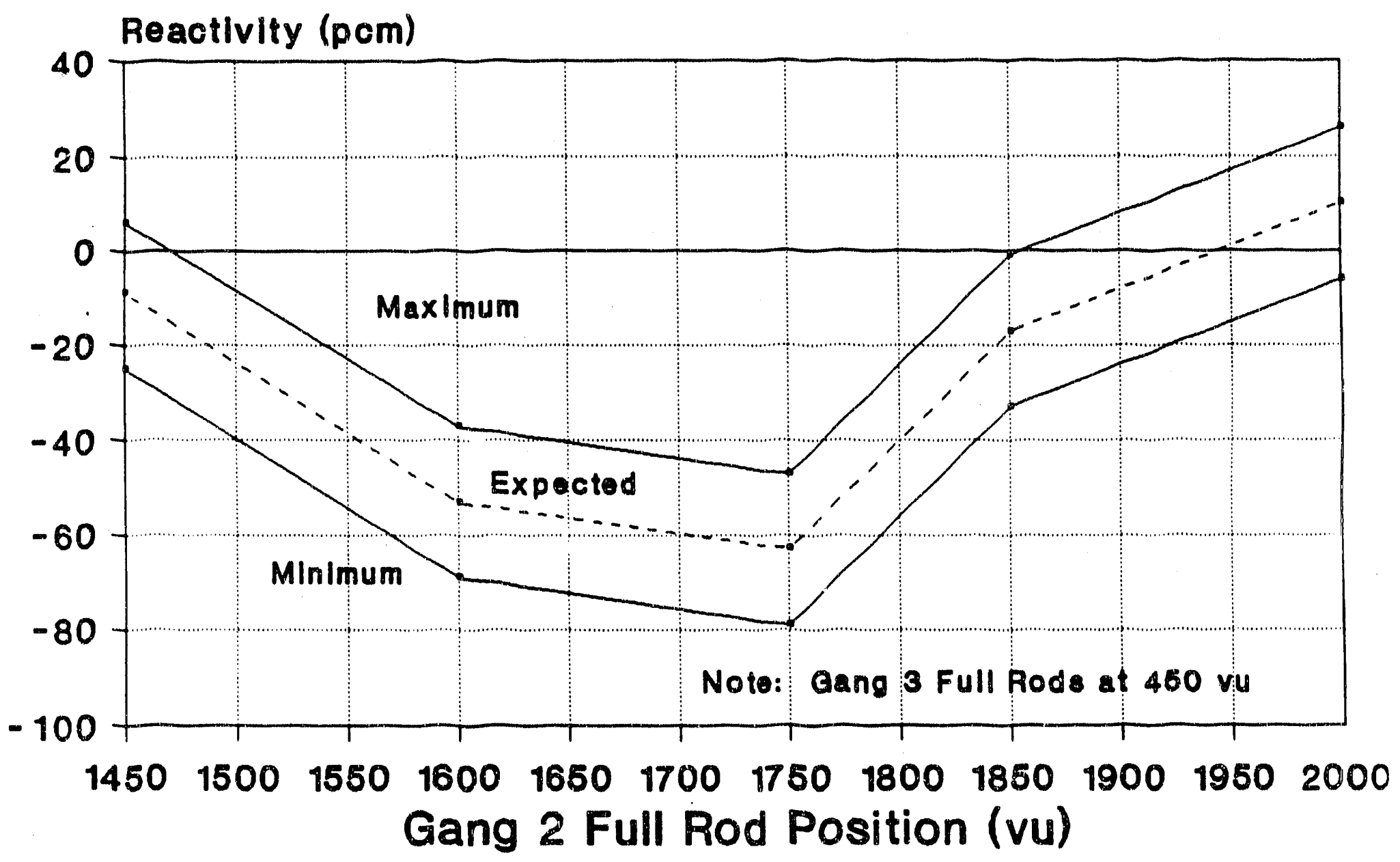


WSRC-TR-91-42-043

Page 119 of 138

June 4, 1981

\section{FIGURE 91 \\ Gang 3 Partial Rod Insertion 800 vu to 850 vu at $60 \%$ Power}

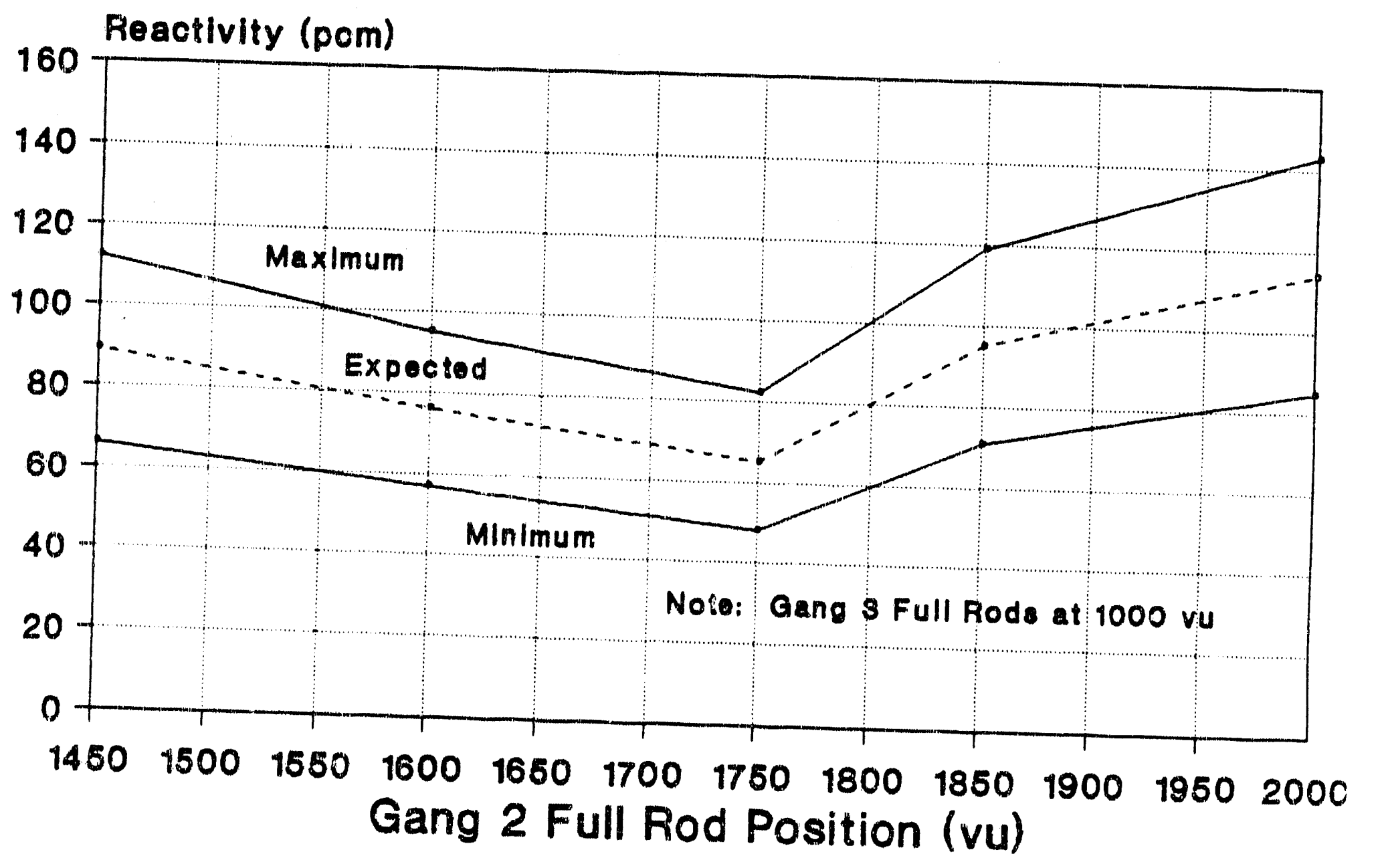


WSRC-TR-91-42-043

Page 120 of 138

June 4, 1991

FIGURE 92

Safety Rod SCRAM

Flat Core and No Rods Missing

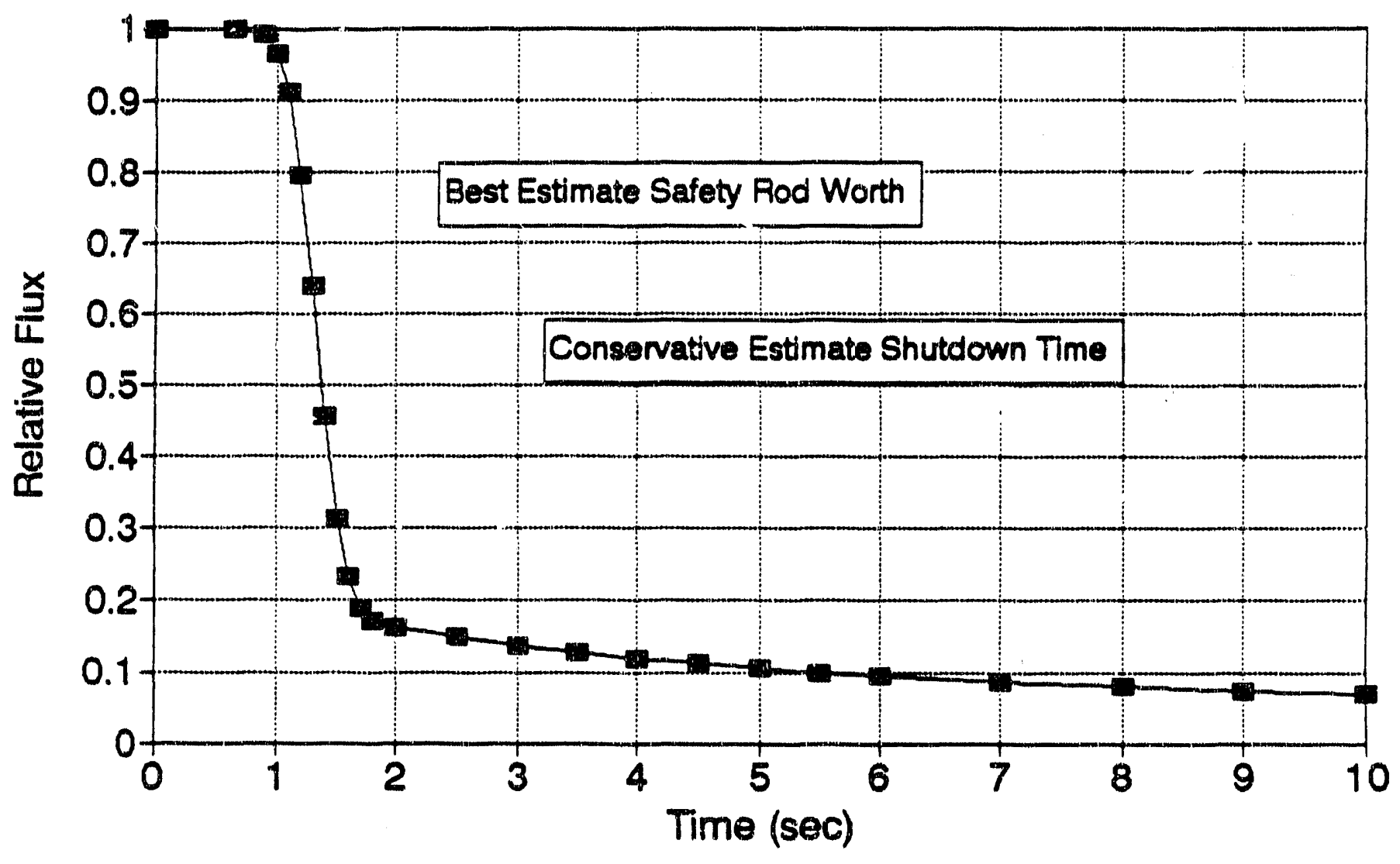


WSRC-TR-91-42-043

Page 121 of 133

June 4, 1991

FIGURE 93

Reactivity Worth of Fission Products After Shutdown From 400 MW Equilibrium

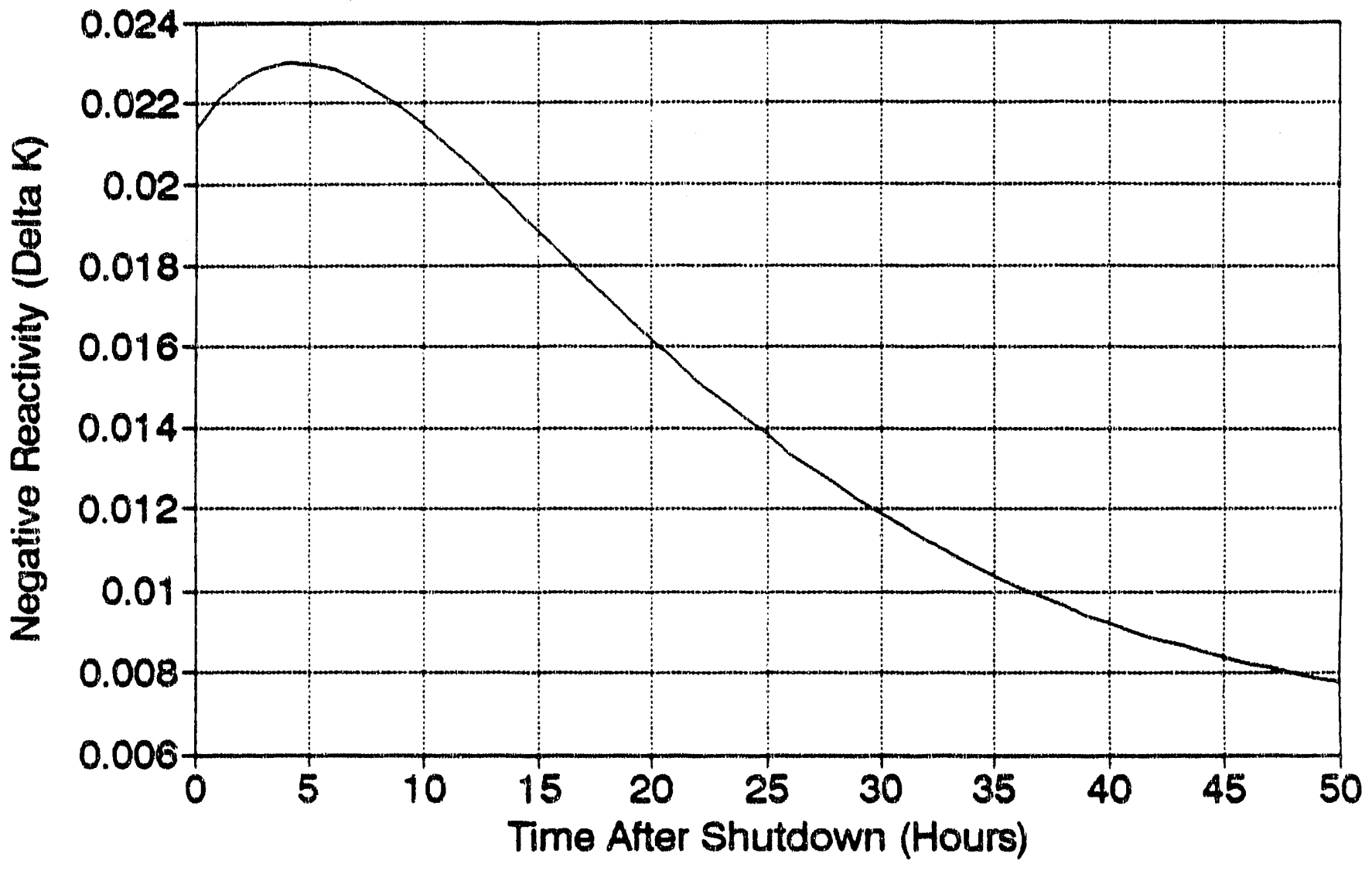


WSRC-TR-91-42-043

Page 122 of 138

June 4, 1991

FIGURE 94

Reactivity Worth of Fission Products After Shutdown From 450 MW Equilibrium

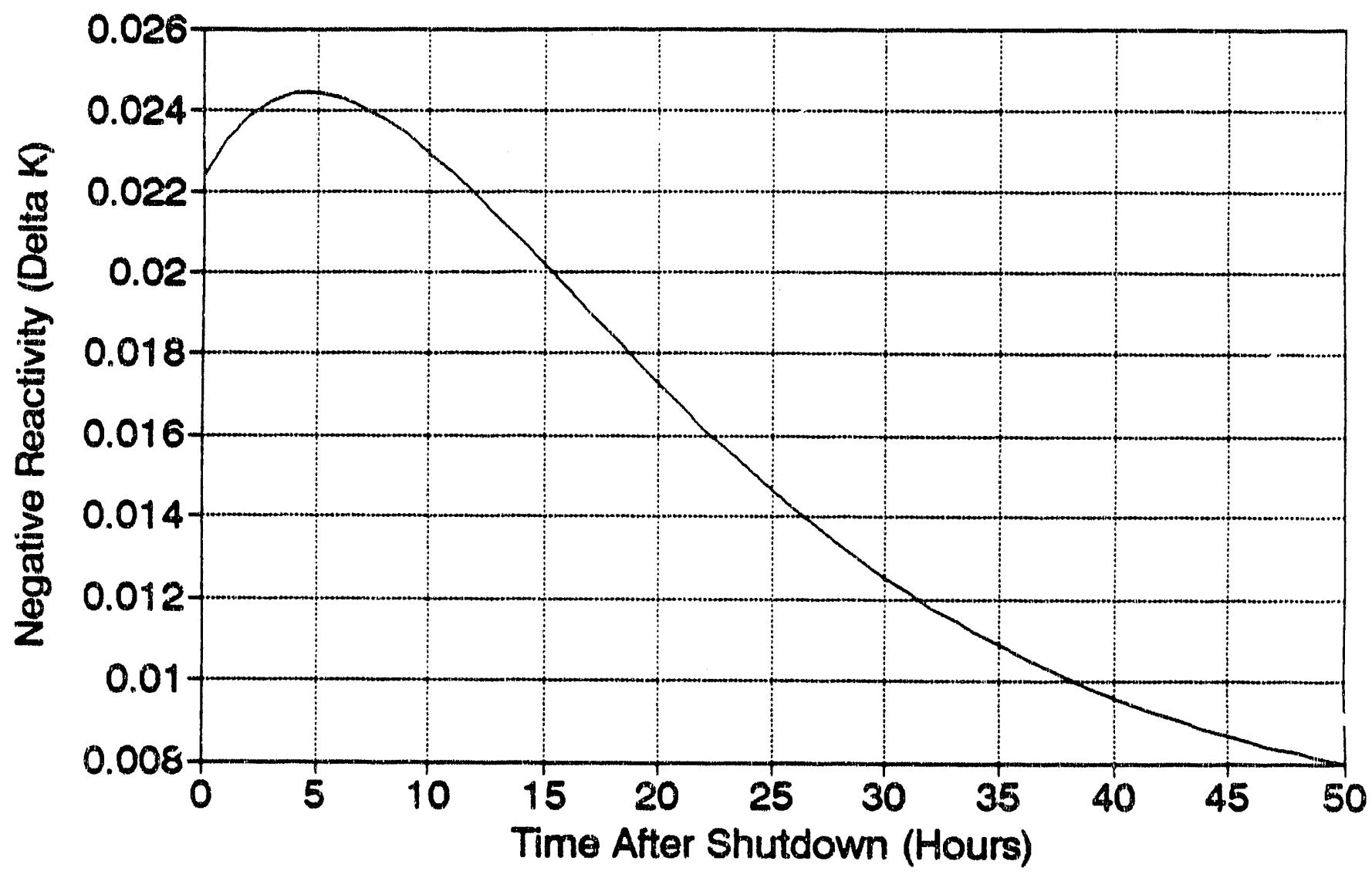


WSRC-TR-91-42-043

Page 123 of 138

June 4, 1991

FIGURE 95

Reactivity Worth of Fission Products After Shutdown From 500 MW Equilibrium

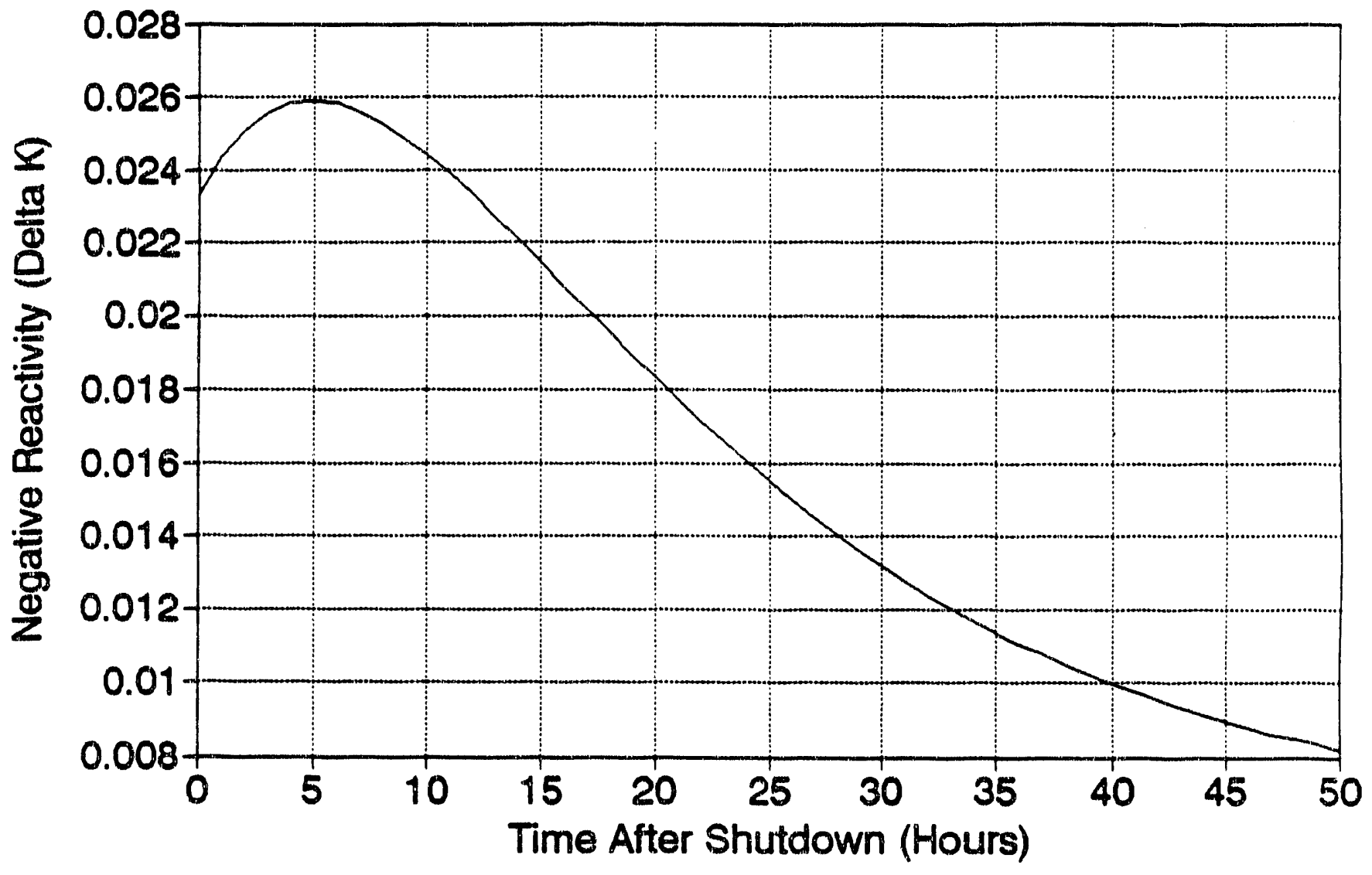


WSRC-TR-91-42-043

Page 124 of 138

June 4, 1991

FIGURE 96

\section{Reactivity Worth of Fission Products After Shutdown From 550 MW Equilibrium}

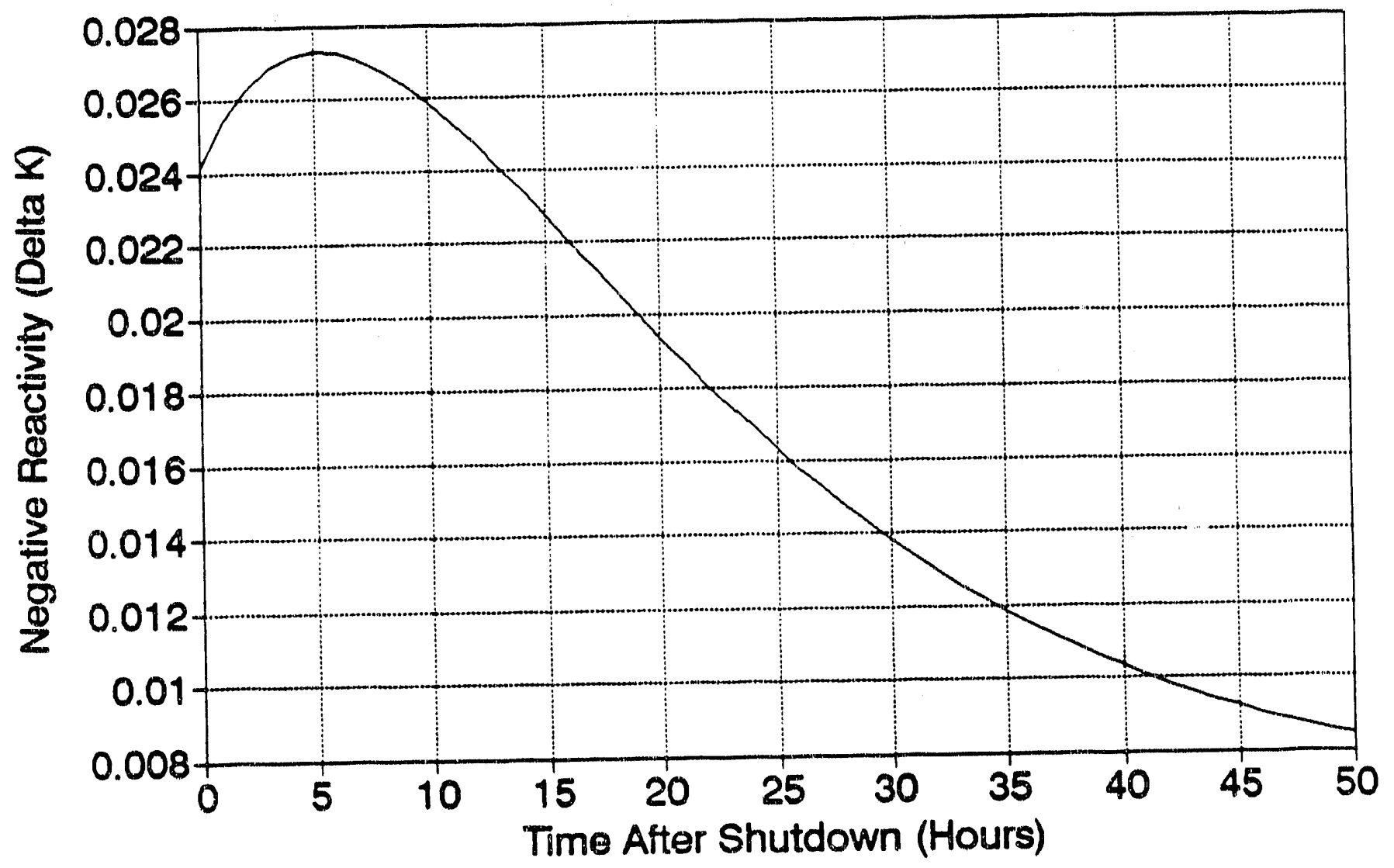


WSAC-TR-91-42-043

Page 125 of 138

June 4, 1991

FIGURE 97

\section{Reactivity Worth of Fission Products After Shutdown From $600 \mathrm{MW}$ Equilibrium}

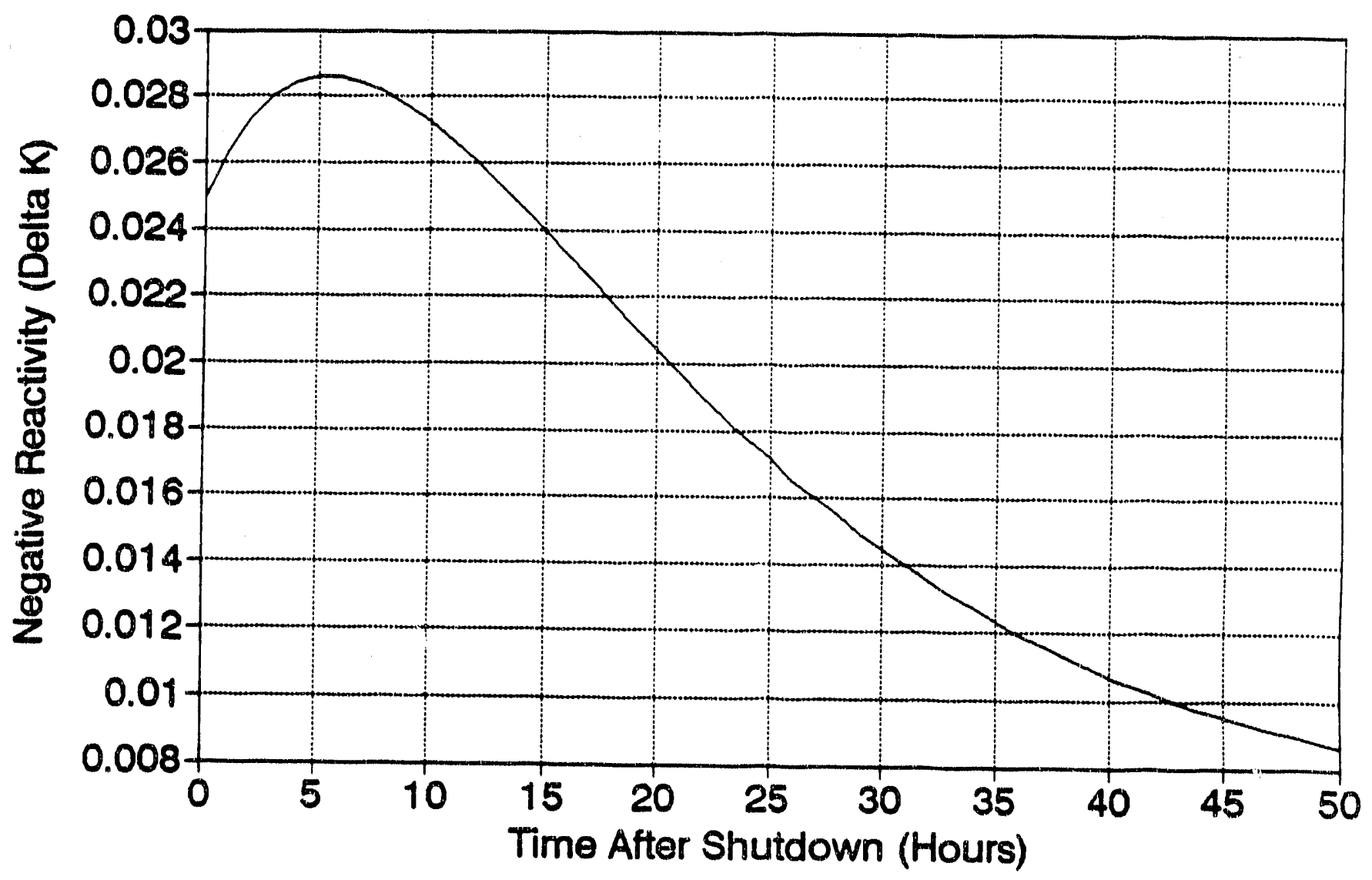


WSRC-TR-91-42-043

Page 126 of 138

June 4, 1991

FIGURE 98

\section{Reactivity Worth of Fission Products After Shutdown From 650 MW Equilibrium}

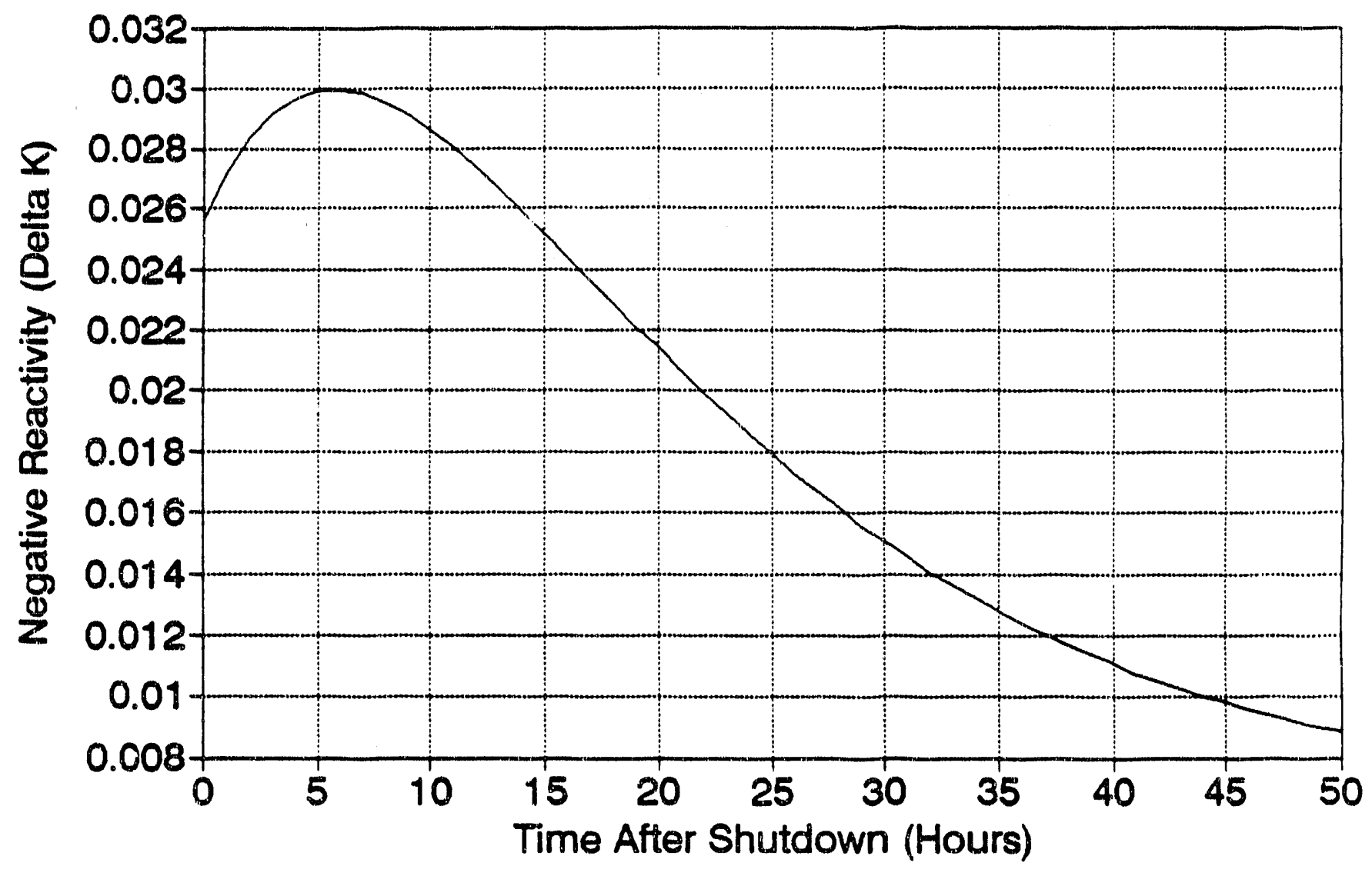


WSRC-TR-91-42-043

Page 127 of 138

June 4, 1991

FIGURE 99

\section{Reactivity Worth of Fission Products After Shutdown From 700 MW Equilibrium}

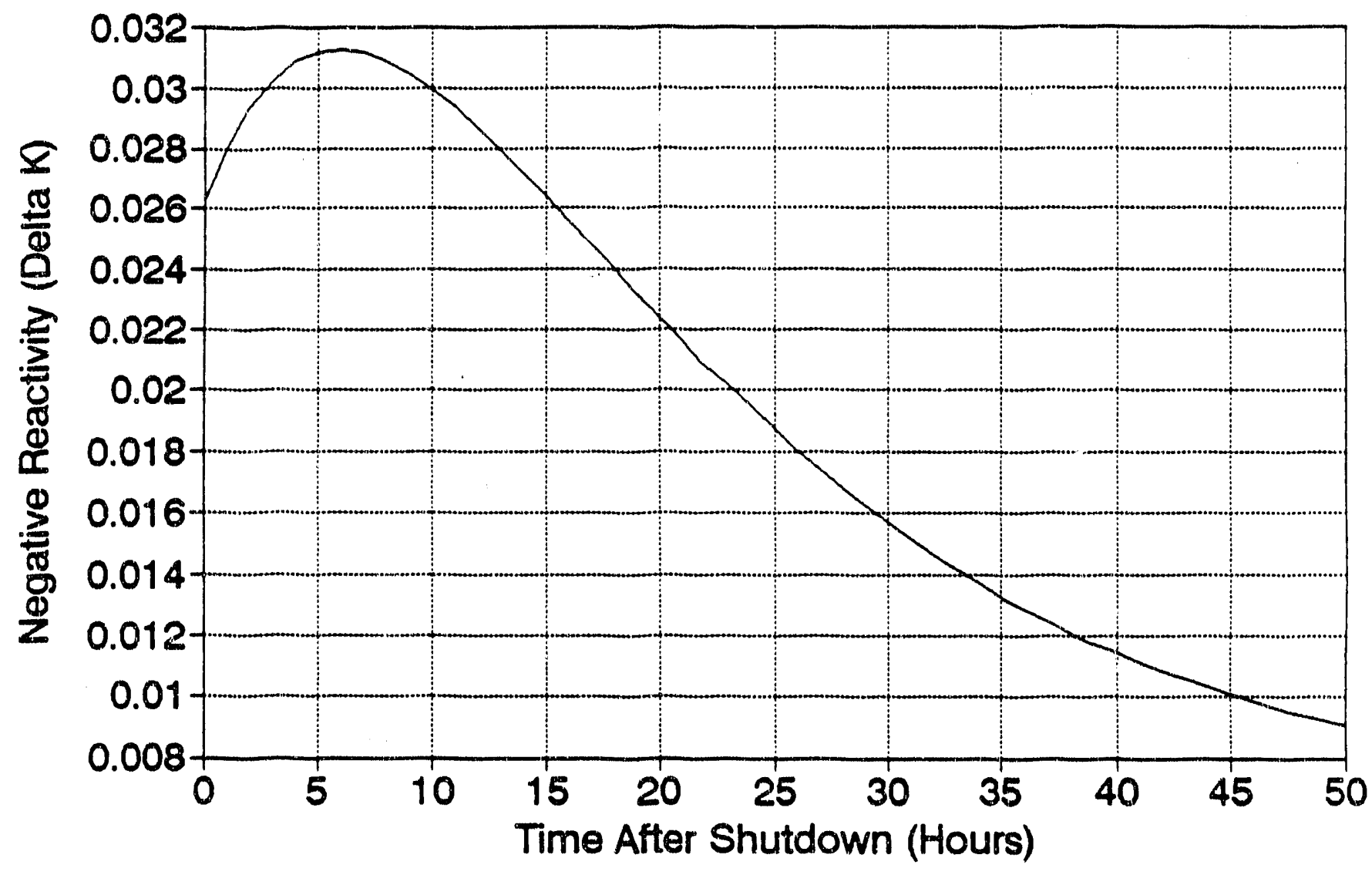


WSRC-TR-91-42-043

Page 128 of 138

June 4, 1991

FIGURE 100

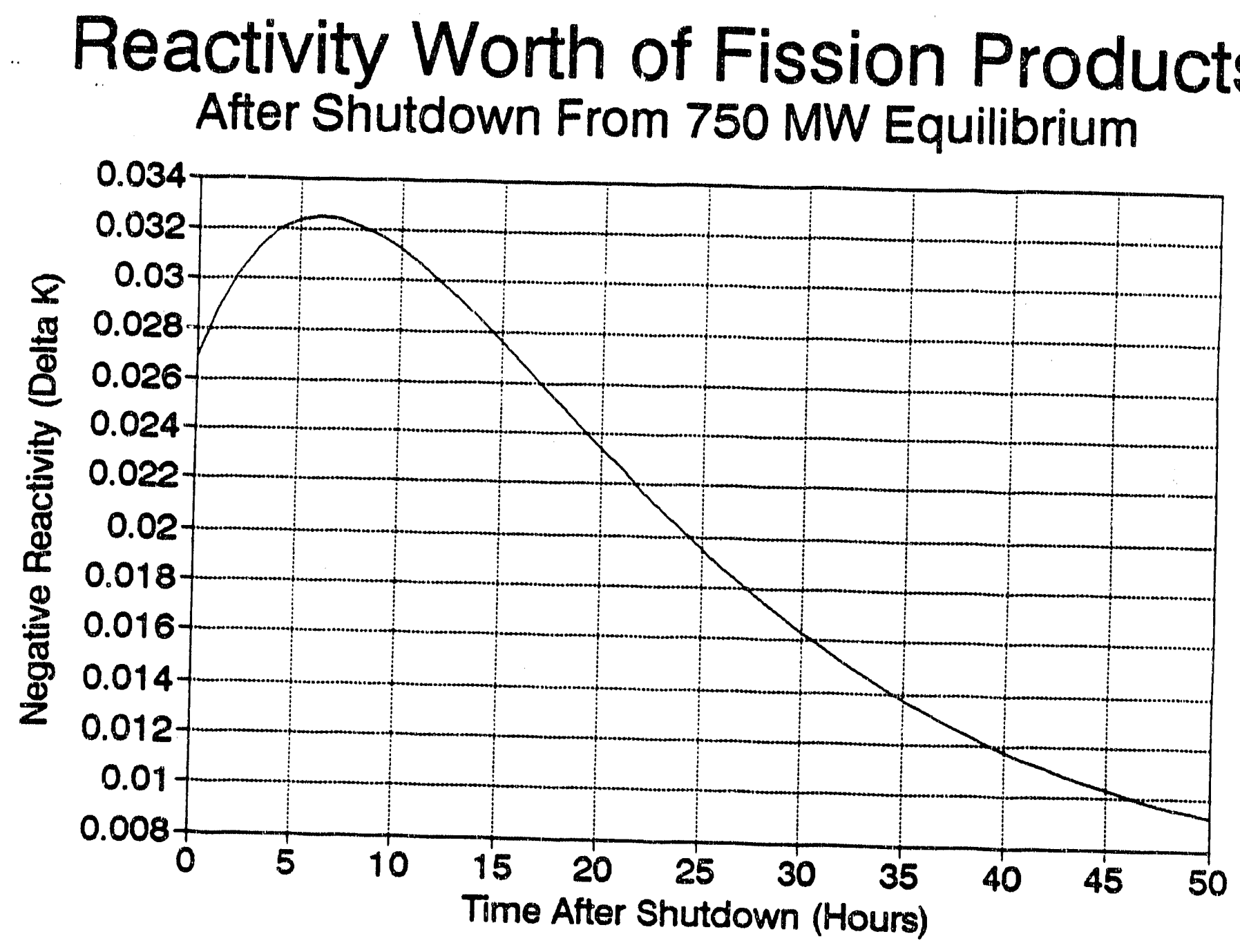


WSRC-TR-91-42-043

Page 129 of 138

June 4, 1991

FIGURE 101

\section{Reactivity Worth of Fission Products After Shutdown From $800 \mathrm{MW}$ Equilibrium}

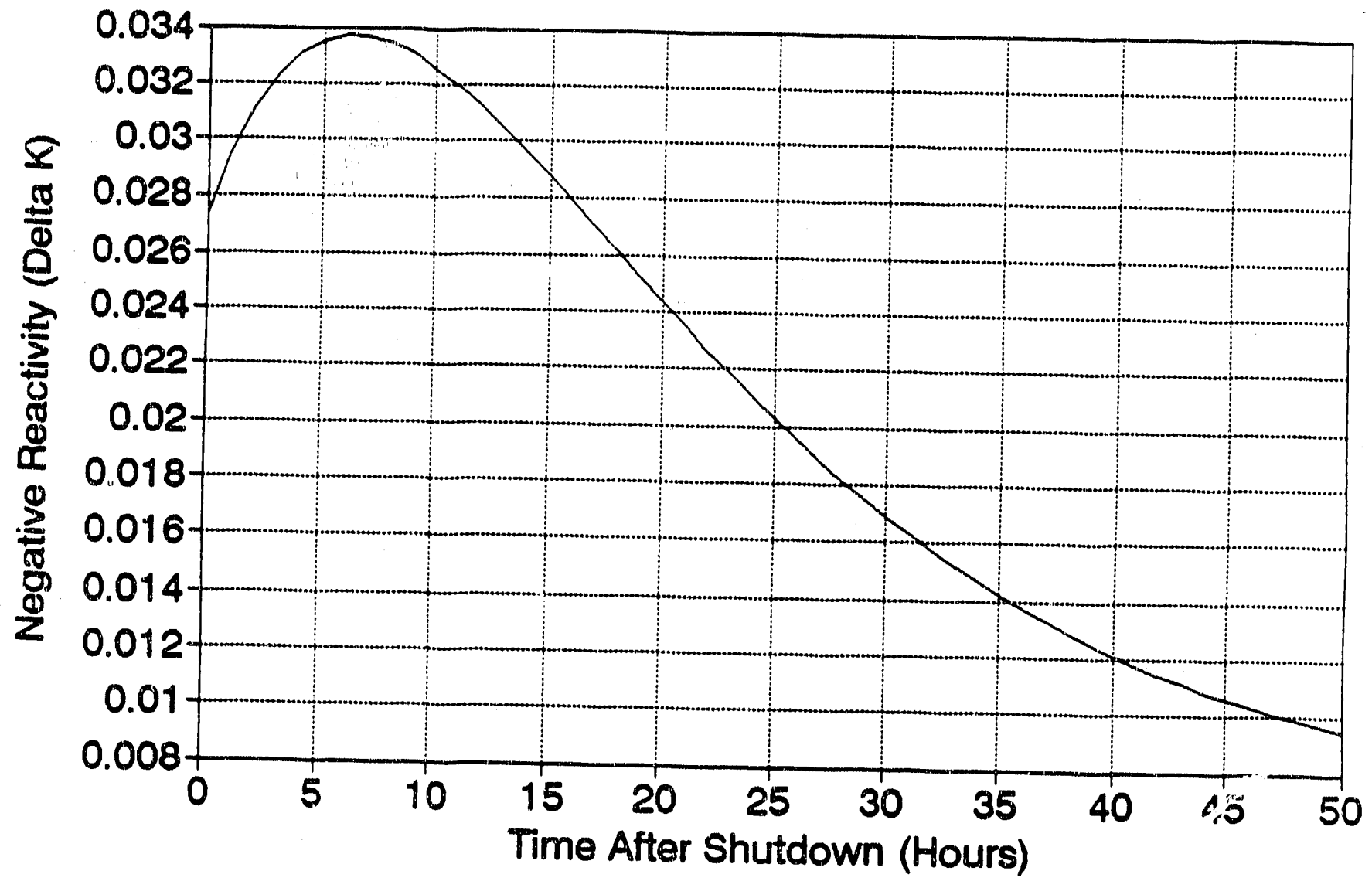


WSRC-TR-91-42-043

Page 130 of 138

June 4, 1991

FIGURE 102

\section{Reactivity Worth of Fission Products After Shutdown From 850 MW Equilibrium}

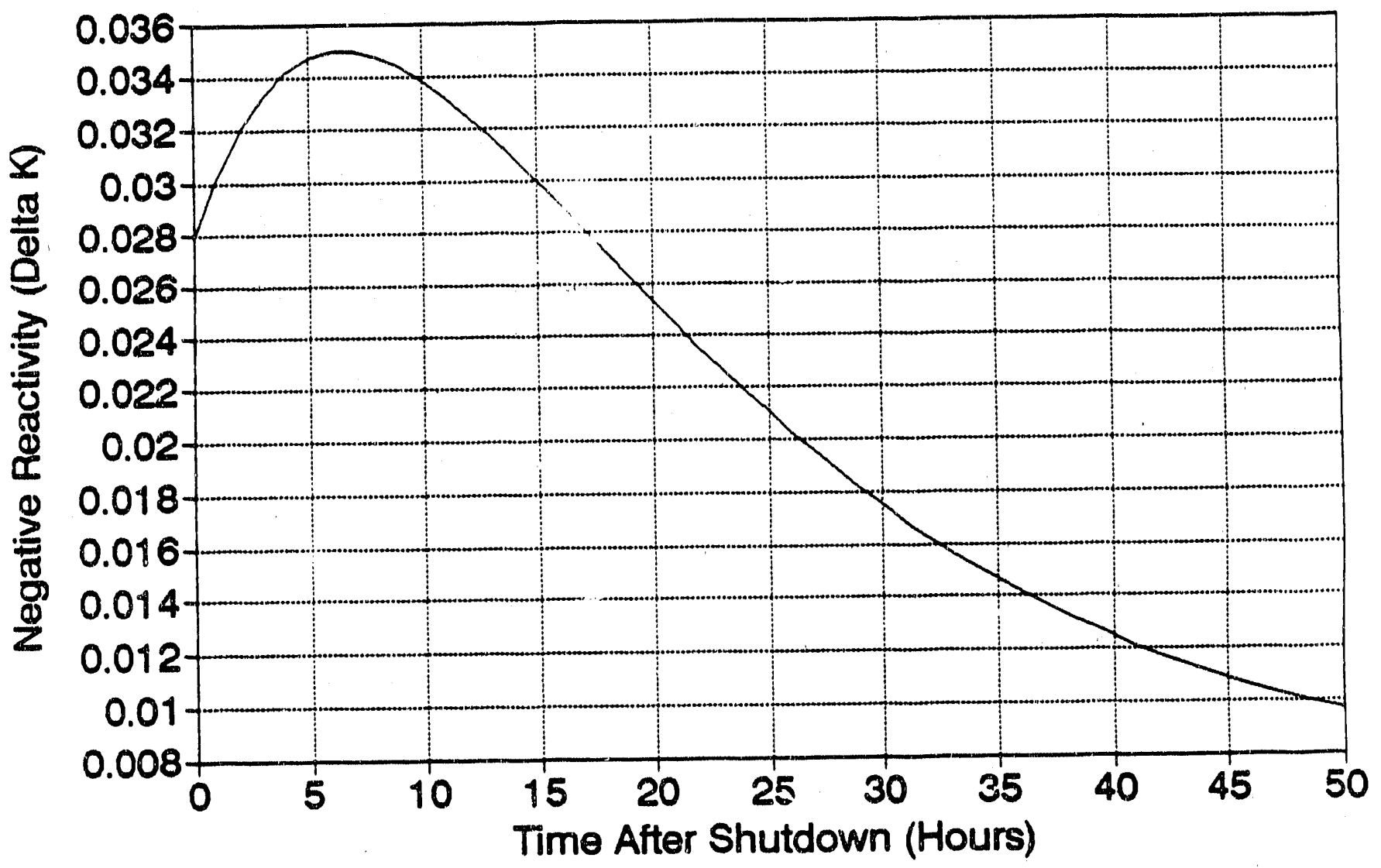


WSRC-TR-91-42-043

Page 131 of 138

June 4, 1991

FIGURE 103

\section{Reactivity Worth of Fission Products After Shutdown From 900 MW Equilibrium}

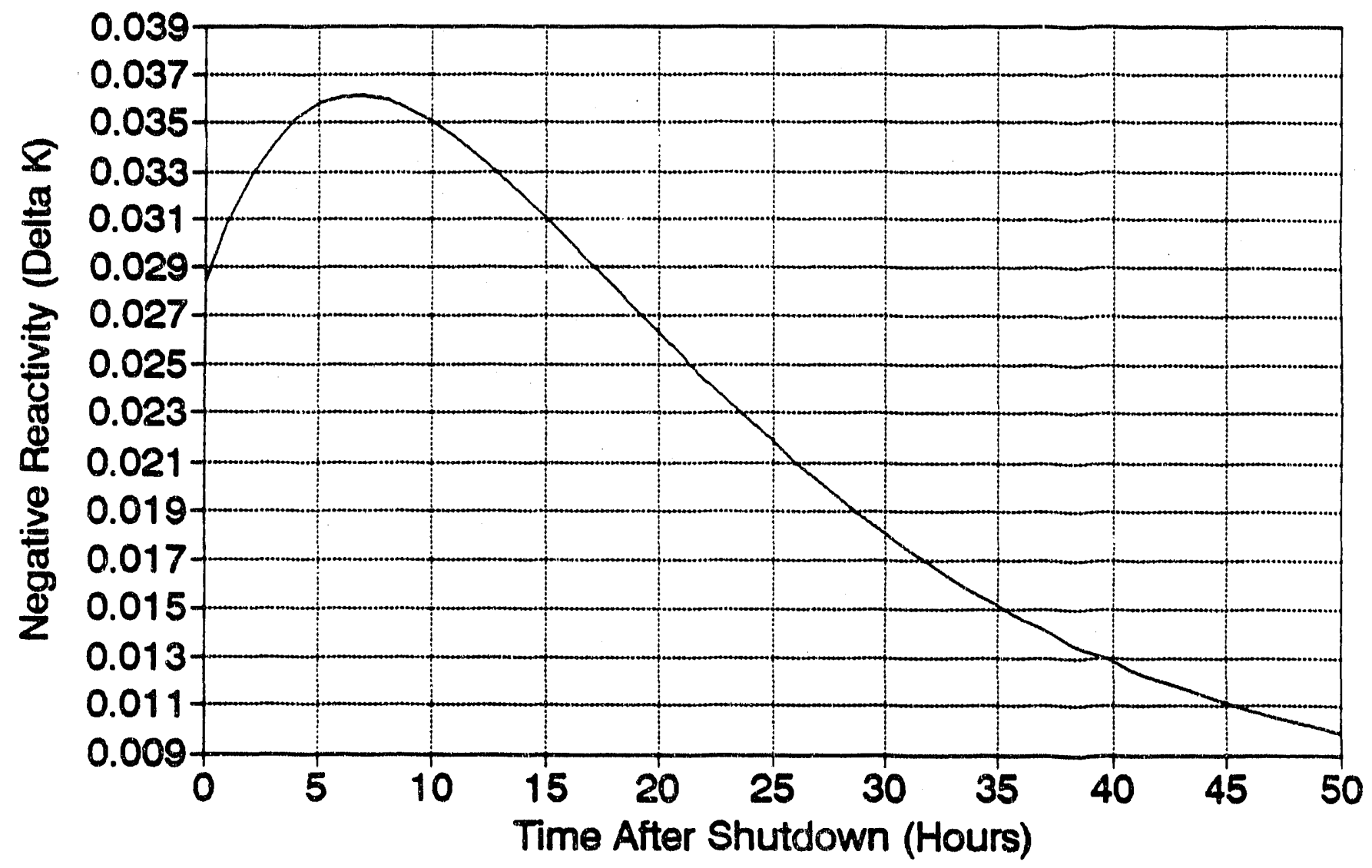


WSRC-TR-91-42-043

Page 132 of 138

June 4, 1991

FIGURE 104

\section{Reactivity Worth of Fission Products After Shutdown From 950 MW Equilibrium}

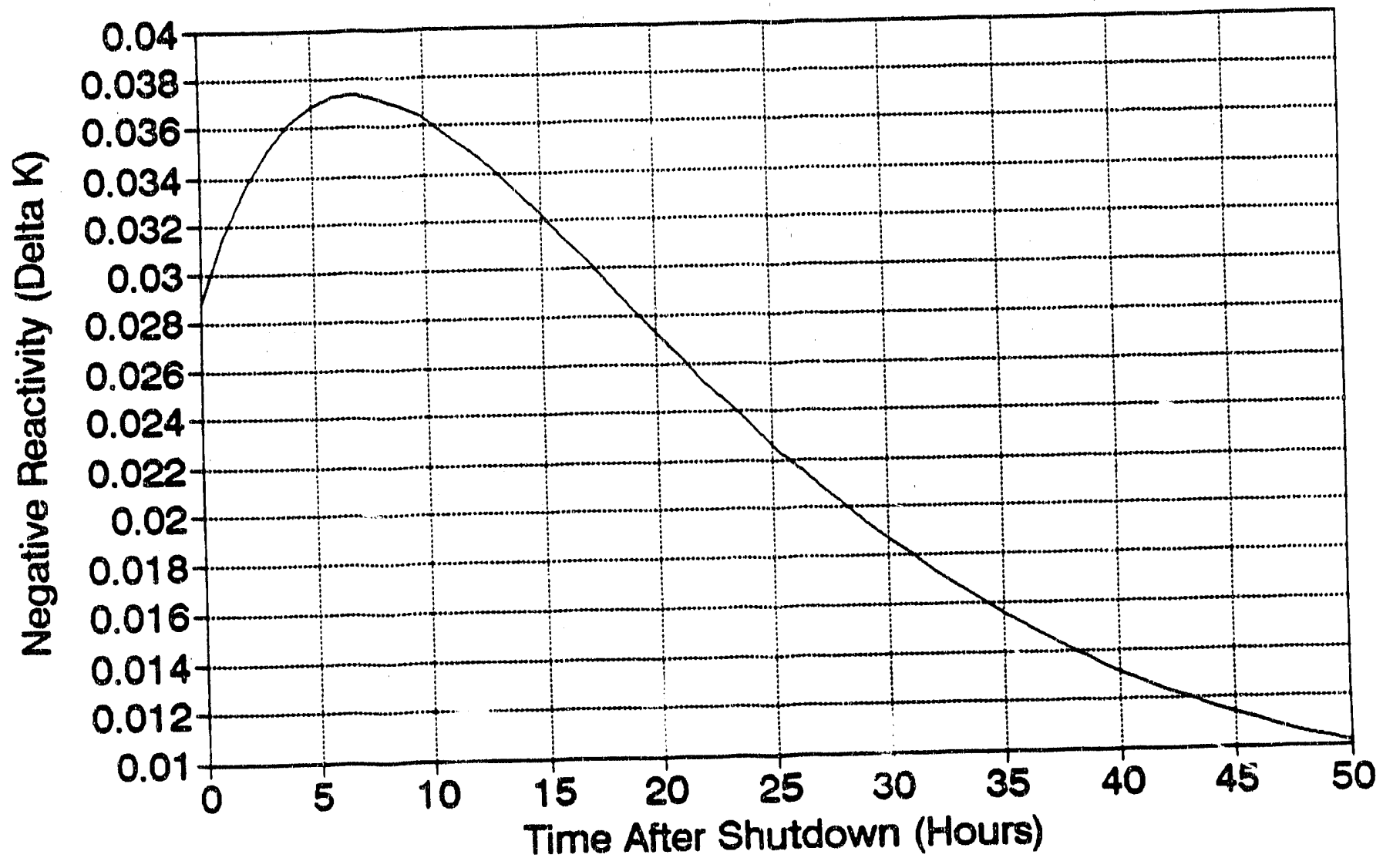


WSRC-TR-91-42-043

Page 133 of 138

June 4, 1991

FIGURE 105

\section{Reactivity Worth of Fission Products After Shutdown From 1000 MW Equilibrium}

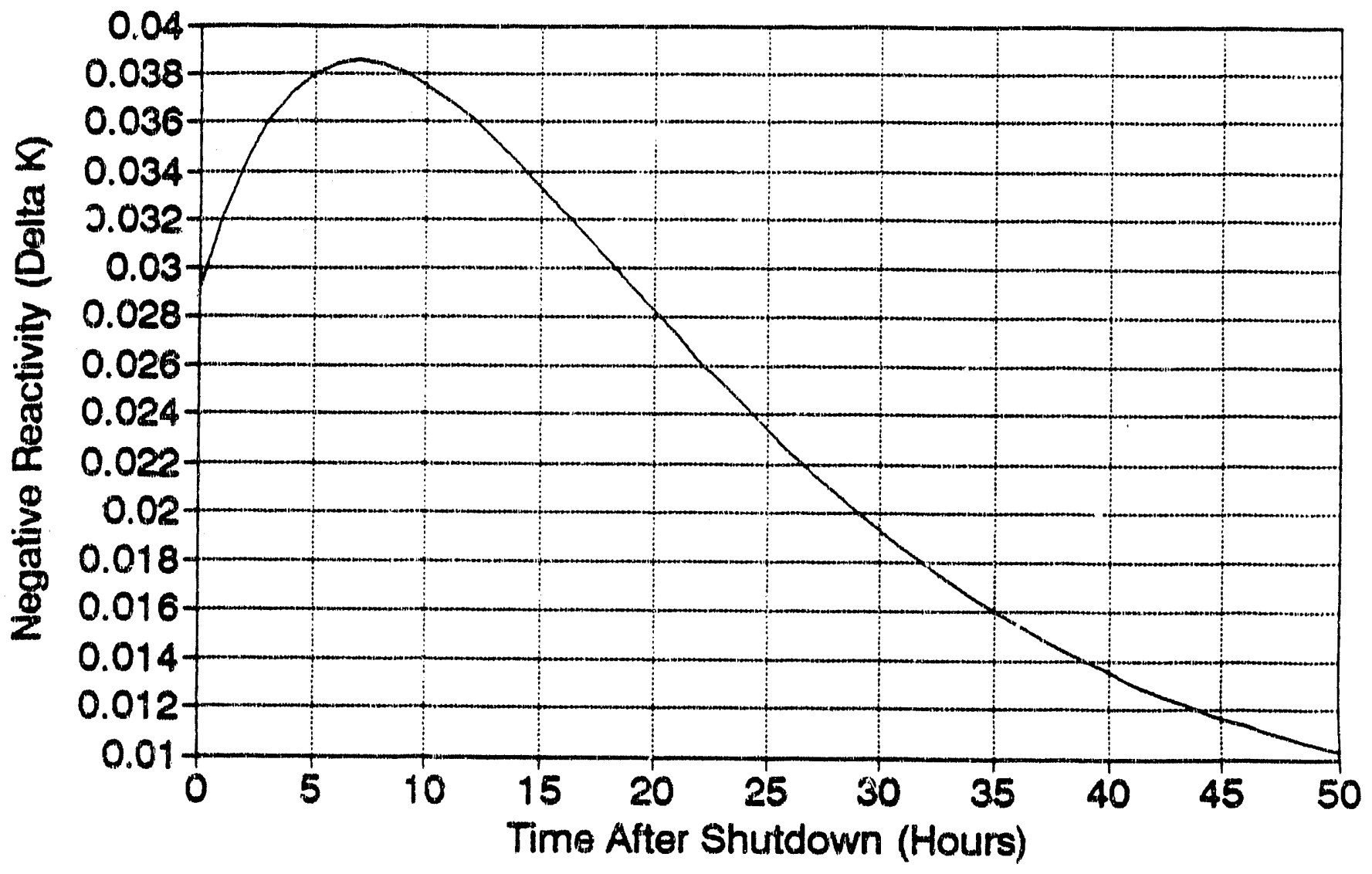


WSRC-TR-91-42-043

Page 134 of 138

June 4, 1991

FIGURE 106

Reactivity Worth of Fission Products After Shutdown From 1050 MW Equilibrium

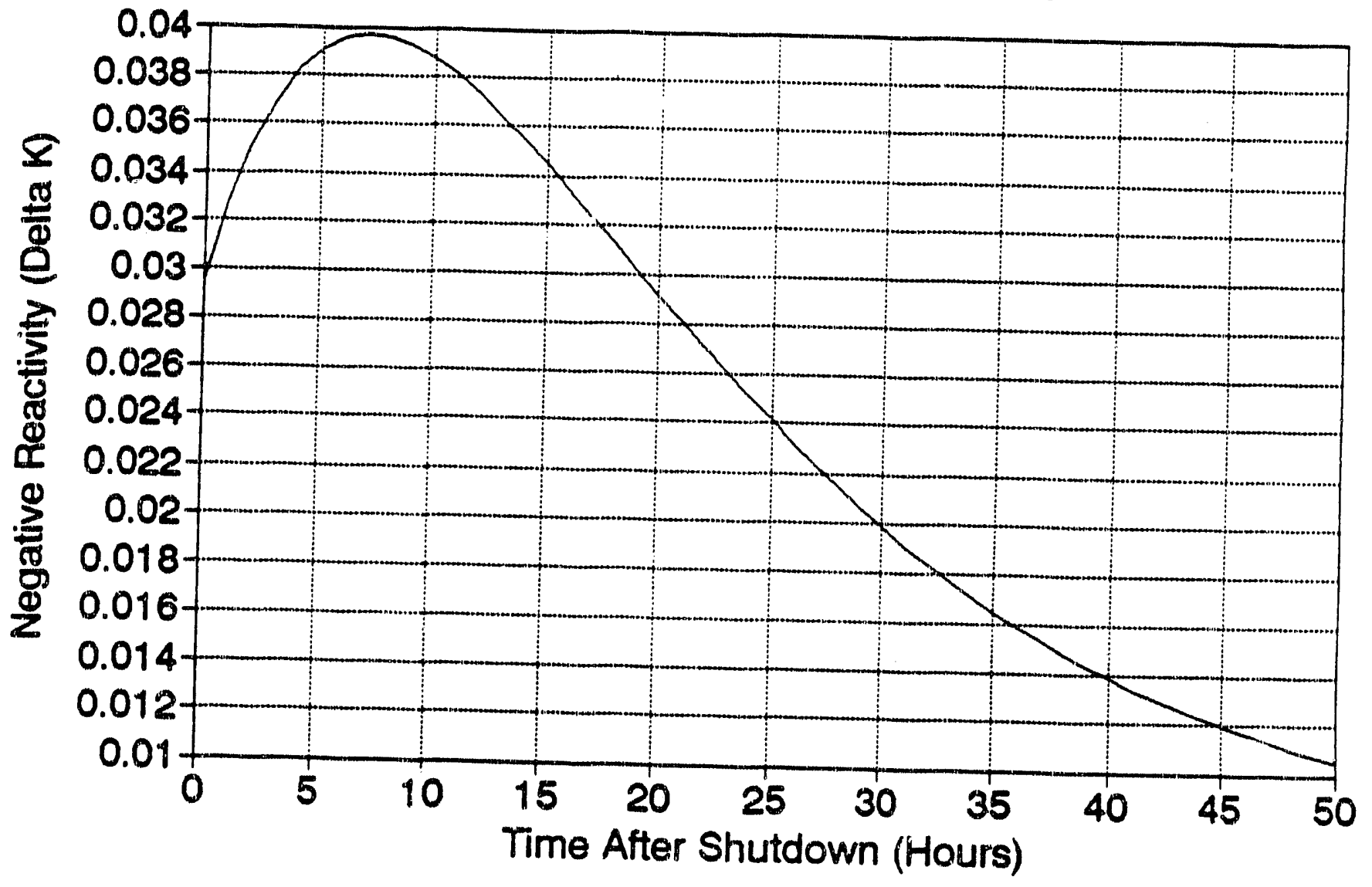


WSRC-TR-91-42-043

Page 135 of 138

June 4, 1991

FIGURE 107

\section{Reactivity Worth of Fission Products After Shutdown From 1100 MW Equilibrium}

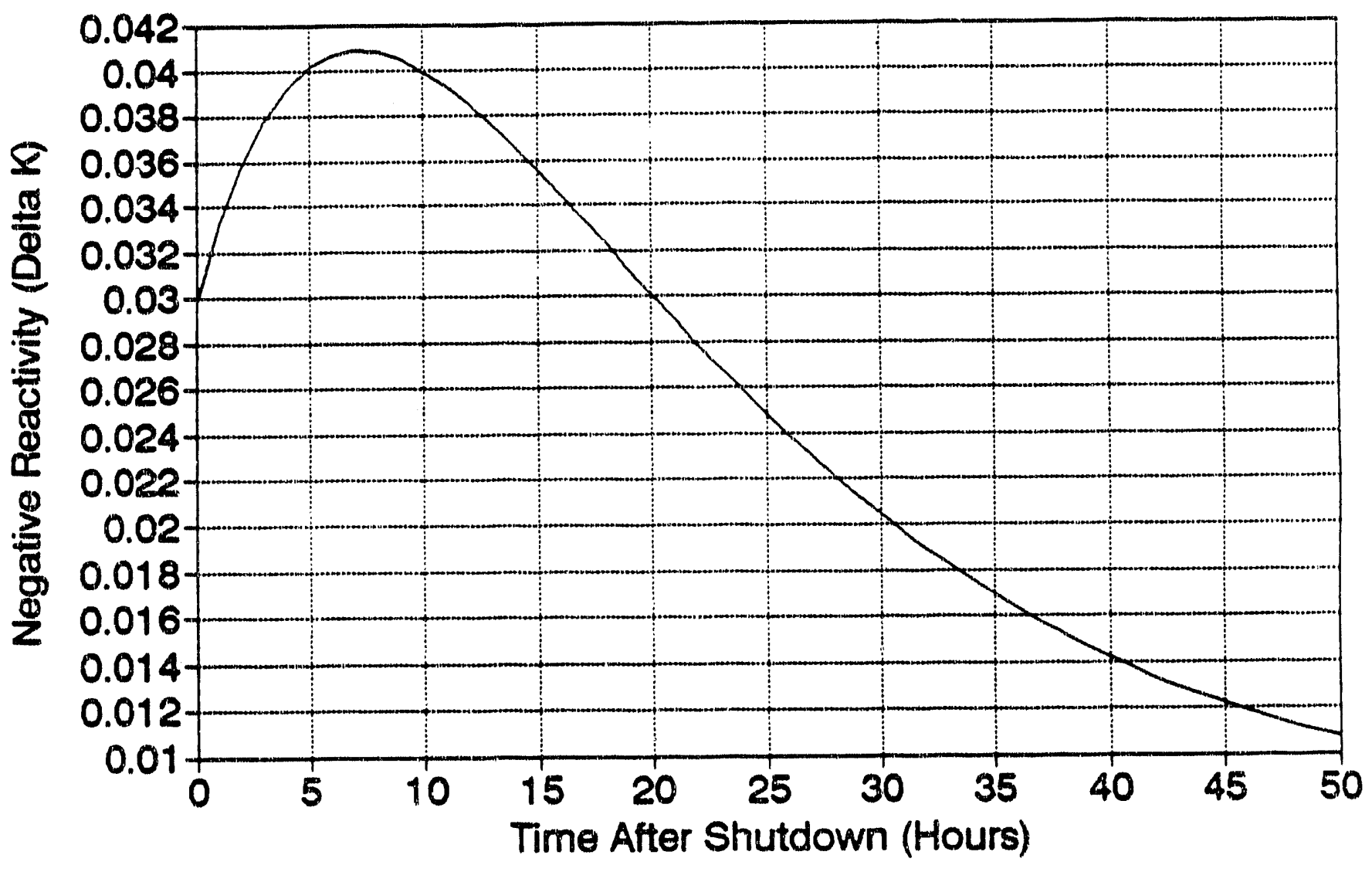


WSRC-TR-91-42-043

Page 136 of 138

June 4, 1991

FIGUAE 108

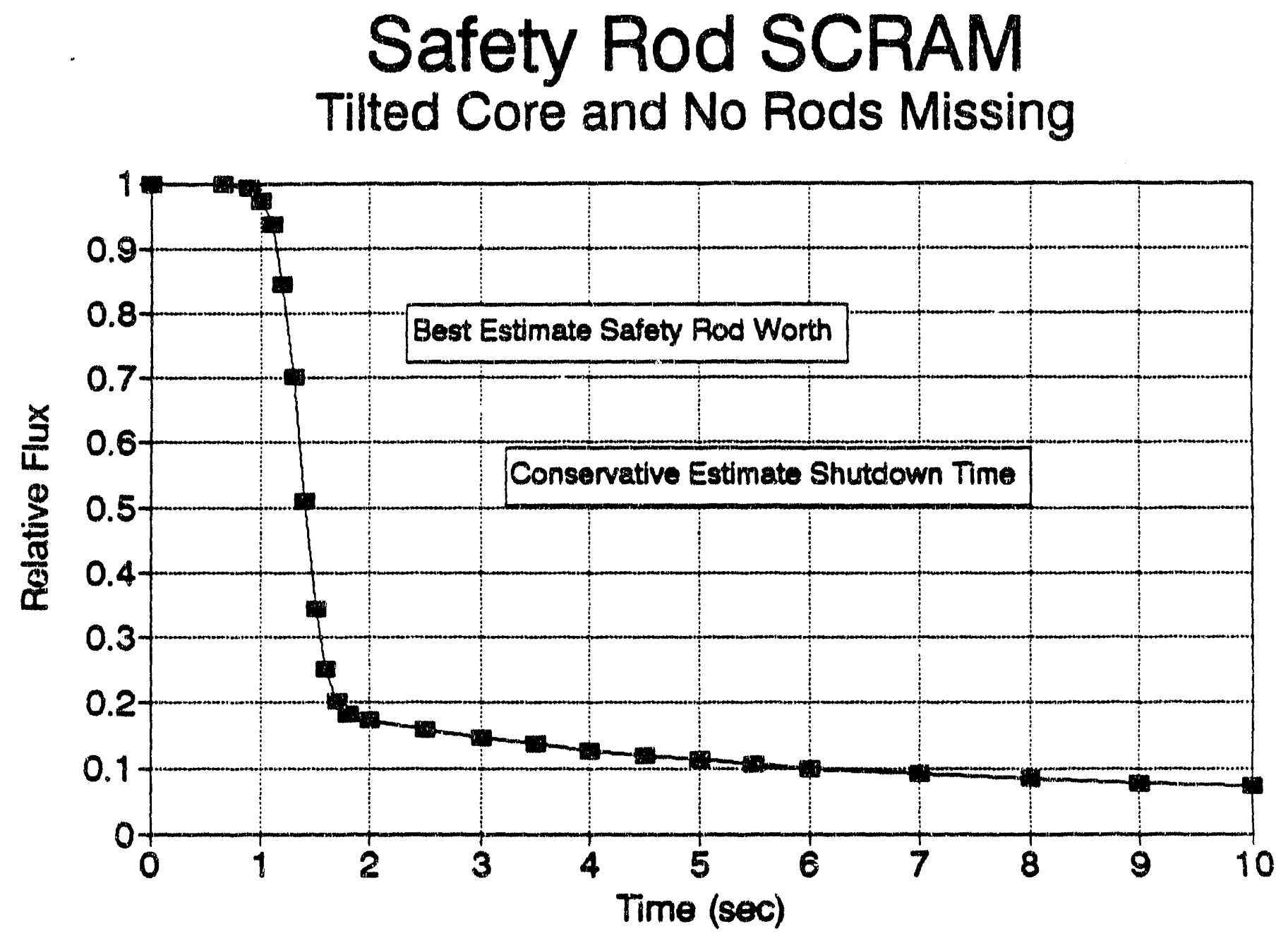


WSRC-TR-91-42-043

Page 137 of 138

June 4, 1991

FIGURE 109

SSS Acceptance Criteria For Relative Flux

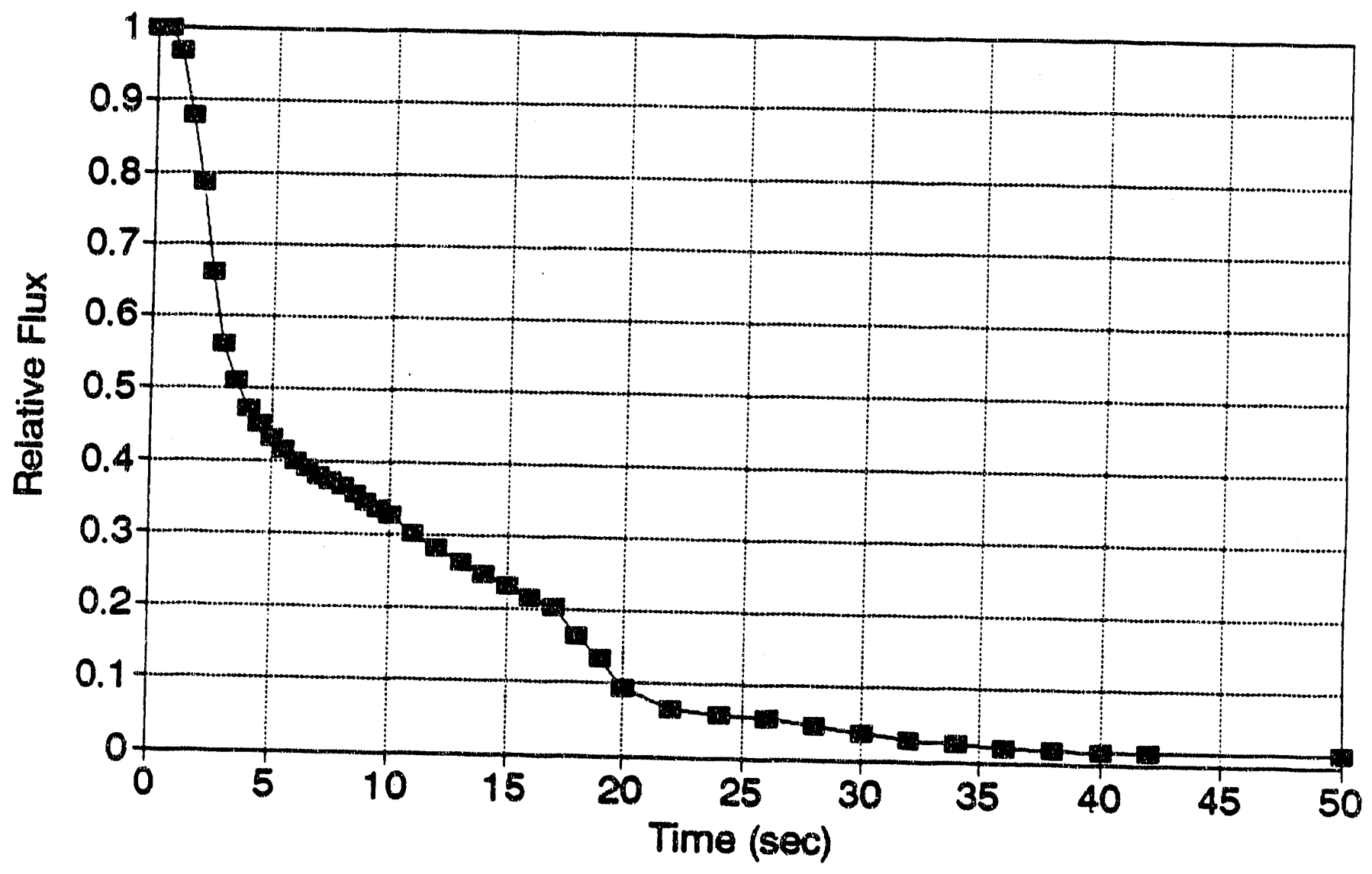


WSRC-TR-91-42-043

Page 138 of 138

June 4, 1991

FIGURE 110

\section{SSS Acceptance Criteria For Relative Assembly Delta $T$}

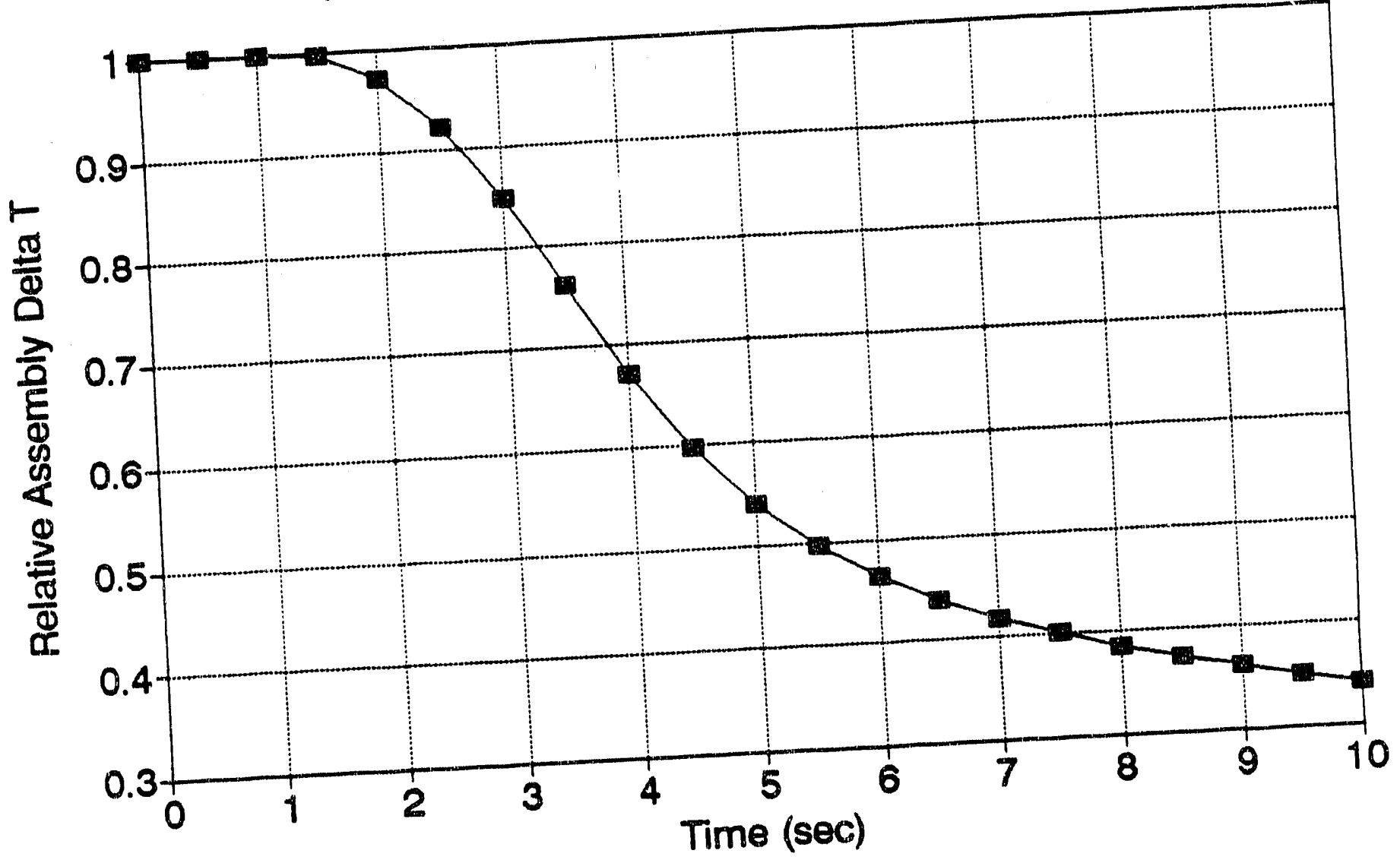



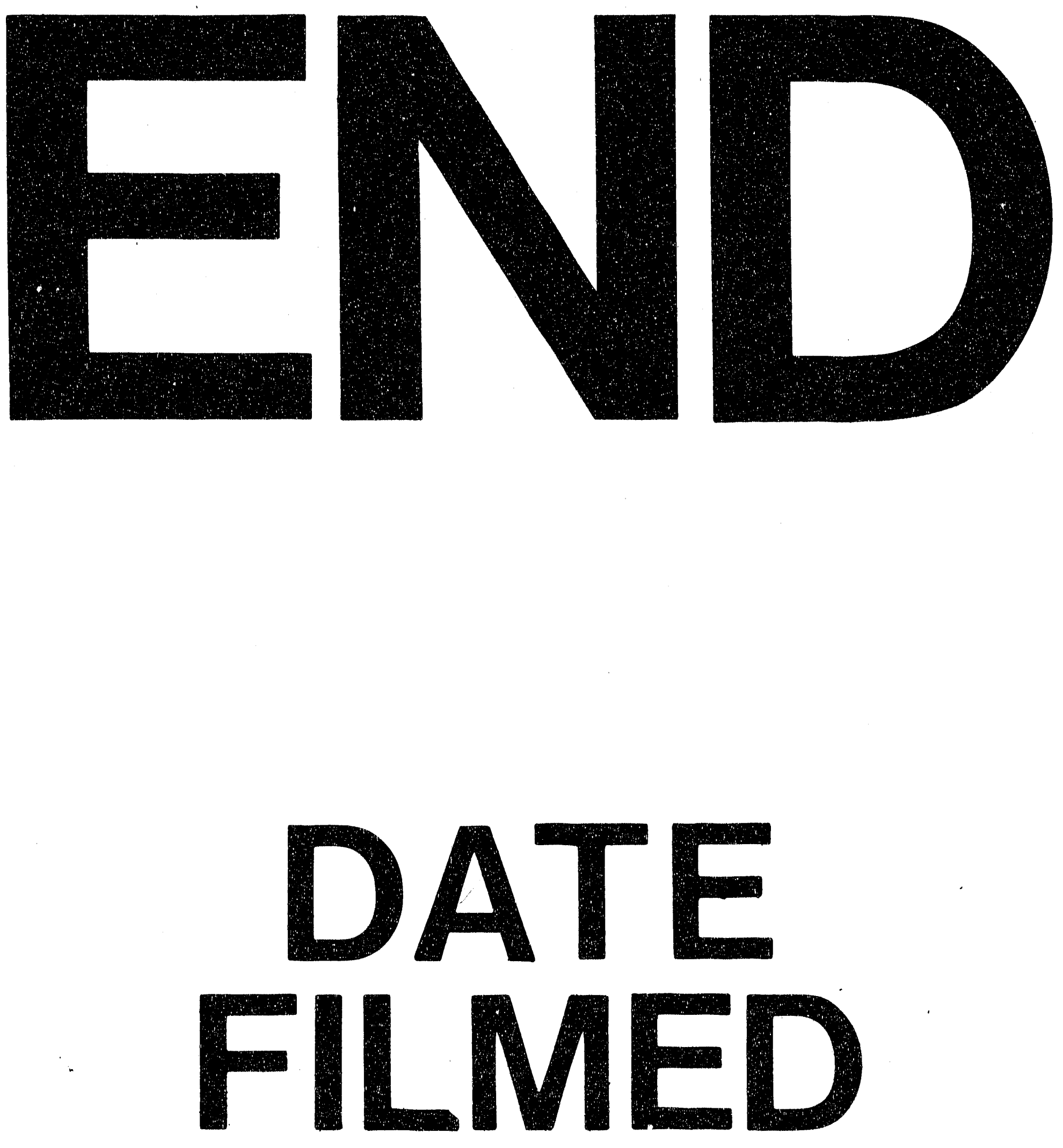

$\exists$

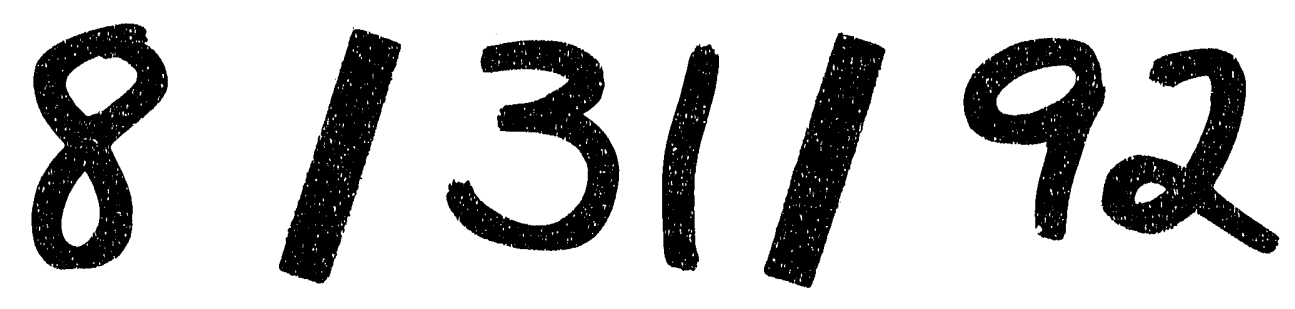


